


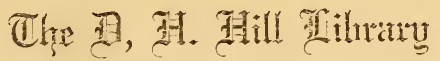

Äarth Carnlima State College

$$
\begin{aligned}
& \text { QK938 } \\
& \square 455
\end{aligned}
$$


This BOOK may be kept out TWO WEEKS ONLY, and is subject to a fine of FIVE CENTS a day thereafter. It is due on the day indicated below:

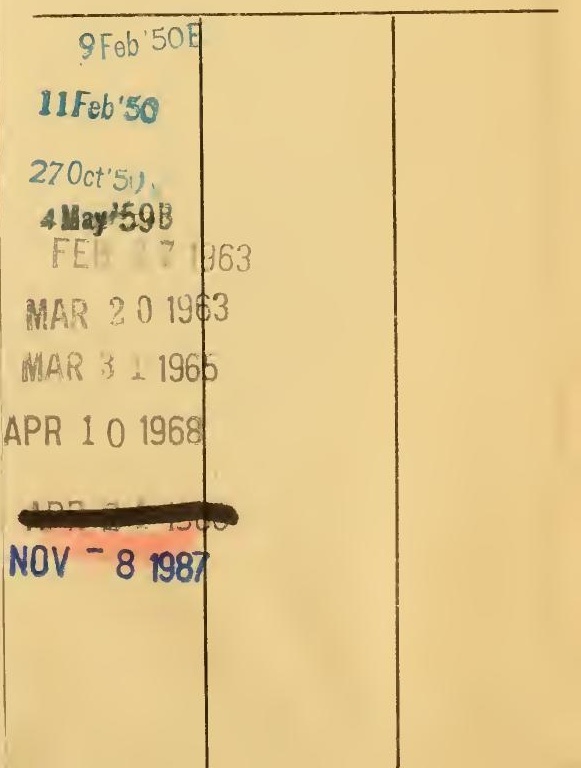







\title{
THE VEGETATION OF A DESERT MOUNTAIN RANGE AS CONDITIONED BY CLIMATIC FACTORS
}

\author{
BY \\ FORREST SHREVE
}

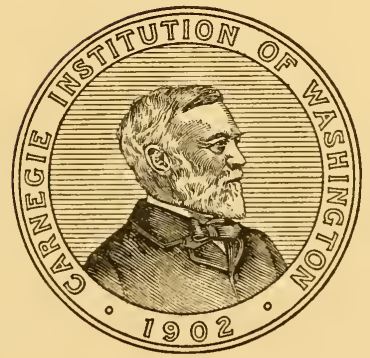

WASHINGTON, D. C.

Poblished by the Carnegie Institution of Washington 1915 
CARNEGIE INSTITUTION OF WASHINGTON

Publication No. 217

Copies of this Book

were first issusd

OCT 281915

PRESS OF J. B. LIPPINCOTT COMPANY

PHILADELPHIA 


\section{N. O. SERARY COllege}

\section{CONTENTS.}

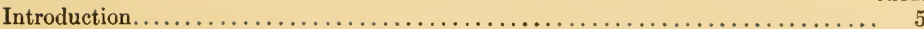

Geography and Topography of the Santa Catalina Mountains............... 6

Vegetation of the Santa Catalina Mountains.............................. 11

The Desert Region....................................... 15

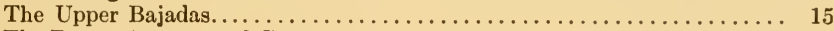

The Desert Arroyos and Cañons. . . . . . . . . . . . . . . . . . . . . . . 19

The Lower Desert Slopes.................................... 22

The Upper Desert Slopes................................... 23

The Encinal Region.................................... 24

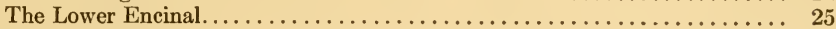

The Upper Encinal................................... 27

The Forest Region ..................................... 29

The Pine Forest................................... 31

The Fir Forest........................................ 33

Flora of the Santa Catalina Mountains.......................... 36

Phytogeographic Relationships of the Flora..................... 36

The Desert Flora.................................. 36

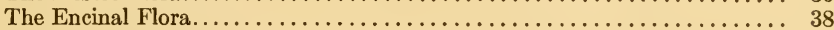

The Forest Flora ................................... 39

List of Characteristic Species............................. 41

Climate of the Santa Catalina Mountains........................... 46

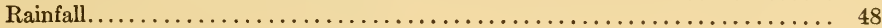

Seasonal Distribution of Rainfall................................ 48

Altitudinal Increase of Rainfall. .......................... 51

Soil Moisture.......................................... 59

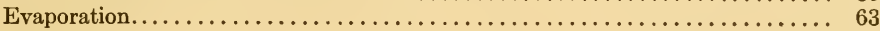

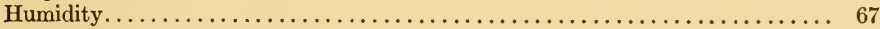

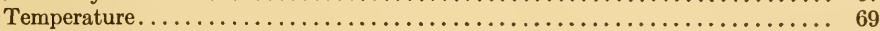

Length of Frostless Season............................ 70

Normal Altitudinal Temperature Gradient......................... 75

The Absolute Minimum of Winter......................... 79

Departures from the Normal Temperature Gradient due to Cold-air Drainage 82

Soil Temperature.................................... 86

Correlation of Vegetation and Climate in the Santa Catalina Mountains........... 88

The Normal Altitudinal Gradient of Vegetation..................... 88

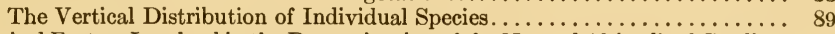

Physical Factors Involved in the Determination of the Normal Altitudinal Gradient

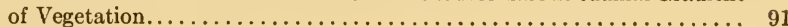

Moisture Factors..................................... 92

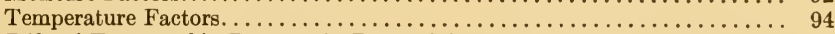

The Rôle of Topographic Features in Determining Departures from the Normal Altitudinal Gradient of Vegetation....................... 97

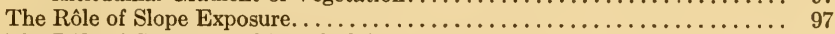

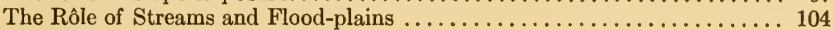

The Rôle of Topographic Relief................................... 107

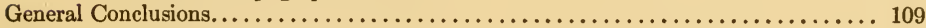




\title{
THE VEGETATION OF A DESERT MOUNTAIN RANGE AS CONDITIONED BY CLIMATIC FACTORS.
}

\author{
INTRODUCTION.
}

The southern half of the state of Arizona may be briefly characterized as a relatively level plain studded with numerous hills and mountains. The plain rises from elevations of a few hundred feet along the Colorado River to as much as 4,500 and 5,000 feet near the New Mexican boundary. The lower elevations follow the Gila, Salt, San Pedro, and other rivers, while the higher plains surround the loftier mountains of the southeastern portion of the State. Between the Colorado River and Tueson there are no mountains of commanding elevation, and the area occupied by the scattered volcanic peaks and ranges is not more than one-tenth of the total area of the region. To the eastward of Tucson, however, a much greater percentage of the total area is occupied by mountain ranges, a score of which reach elevations of over 8,000 feet. The general topographic configuration of the region has remained unchanged throughout a long period of geological time, and the mountains and hills have been subjected to prolonged erosion, the products of which have served to build up the shelving plains which form the intervening valleys.

Those portions of southern Arizona which lie below 4,000 feet are covered with a low, open, desert vegetation, while the plains and valleys of higher elevation support a loose carpet of perennial grasses and ephemeral herbs, together with a sparse representation of succulent and semi-succulent types of plants. The higher mountain ranges exhibit a graduated sequence of vegetation from that of the desert valleys, through a scrub of evergreen oaks to forests of pine, spruce, and fir. The bodies of mesophilous vegetation which occupy these isolated mountain summits, and the stages which connect them with the vegetation of the desert, present innumerable phenomena of the greatest interest to both physiological and floristic plant geography, and form a most fruitful field of investigation.

The Santa Catalina Mountains are one of the most westerly of the high ranges of southeastern Arizona, and rise from an approximate basal elevation of 3,000 feet to a height of 9,150 feet. With respect to their vegetation these mountains are typical of a large number, not only in Arizona but in southern New Mexico and northern Mexico as well. Their location within 20 miles of Tucson and their ready accessibility from the Desert Laboratory have given opportunity for a study of the distribution of their vegetation and for a measurement of some of the physical factors upon which the existence and activities of the vegetation depend. It is the purpose of the present paper to give a brief description of the vegetistic features of the various altitudes and 
topographic situations in the Santa Catalina Mountains, to give the results of the climatological instrumentation which has been carried on, and to indicate in so far as possible the manner and degree in which the successive altitudinal stages of vegetation are dependent upon the gradients of climatic change by which they are accompanied.

Some of the instrumental records date from the summer of 1907 , the first year in which members of the Desert Laboratory became interested in the mountains, but the principal part of the data to be presented were secured in 1911 and subsequent years. The operation of instruments and the study of vegetation have been made on visits of 5 to 10 days, at intervals between April and October. From three to nine such visits have been made to the mountains in each of the summers since 1910 .

The practical exigencies of the work have limited the character of the instrumentation which could be carried out, but have not impaired the accuracy of the data which it was possible to secure. There is no respect in which the results herewith presented may be considered as more than a mere outline of a large and widely ramifying botanical problem. The central interest of the writer has been to determine which of the major environmental factors are responsible for the chief distributional features of the vegetation, and to ascertain something regarding the intensities of the factors responsible for the distributional limits of individual species, and thereby for the limitation of the types of vegetation themselves. Such an inquiry into the correlations existing between physical conditions and the occurrence and activity of plants may do much to explain general vegetistic phenomena, but it does far more to open up the innumerable physiological problems which must be well known at the outset to underlie these correlations.

\section{GEOGRAPHY AND TOPOGRAPHY OF THE SANTA CATALINA MOUNTAINS.}

The Santa Catalina Mountains occupy the drainage divide between the San Pedro River, a tributary of the Gila, and the Santa Cruz, a river which seldom has sufficient flow to reach an outlet in the Gila. The position of the mountains is between $110^{\circ} 30^{\prime}$ and $111^{\circ}$ east longitude and $32^{\circ} 15^{\prime}$ and $32^{\circ} 35^{\prime}$ north latitude. The general outline of the range is roughly triangular (see plate 40 ), its southern base being at about 3,000 feet $(915 \mathrm{~m}$.) elevation, its northeastern base (parallel to the San Pedro River) lying at approximately 3,500 feet (1,065 m.). To the northwest a broad grassy plain, 3,500 to 3,800 feet in elevation, connects the Santa Catalinas with the lower Tortilla Mountains. To the southeast a narrow pass, 4,300 feet $(1,310 \mathrm{~m}$.) in elevation, connects with the closely adjacent El Rincon Mountains, which reach an elevation of 8,465 feet $(2,580 \mathrm{~m}$.). Southward from El Rincon range a pass of 4,000 feet $(1,220 \mathrm{~m}$.) elevation leads to the Santa Rita range $(9,432$ 
feet, $2,875 \mathrm{~m}$.). To the northeast of the San Pedro River rises the Galiuro range of mountains, the main ridge of which is approximately 35 miles $(57 \mathrm{~km}$.) distant from the Santa Catalinas. The next mountains encountered in passing northeastward are the Pinaleno or Graham range, about 60 miles distant from the Santa Catalinas, and exceeding them in altitude by about 1,400 feet $(427 \mathrm{~m}$.). Beyond the upper course of the Gila River lie the Gila Mountains, and still further to the northeast the White Mountains, which reach an elevation of 11,280 feet $(3,440 \mathrm{~m}$.) in Escudilla Peak. The White Mountains present one of the largest elevated land masses of the State, connecting to the northeast, through the Mogollon Mesa, with the elevated region which surrounds the San Francisco Peaks and supporting a heavy body of forest which extends from the New Mexican boundary nearly to the Grand Cañon. East of the White Mountains the elevated country extends for about 75 miles $(121 \mathrm{~km}$.) into New Mexico, breaking up into several diverging ranges which form a part of the Continental Divide, draining westward into the Gila and eastward into the Rio Grande.

The Santa Catalina Mountains are thus seen to stand at the southwestern terminus of a series of isolated elevations which stretch away from the southern edge of the Colorado Plateau. The valley of the Rio Grande and its tributaries, several undrained basins, and the valley of the Little Colorado combine to separate the entire chain of elevations-San Francisco Mountains, Mogollon Mesa, White Mountains, and the mountains of western New Mexico-from the Sangre de Cristo, San Juan, and Jemez mountains of northern New Mexico, which are virtually a part of the Rocky Mountain system. A considerable degree of isolation from the north is thus given to the entire series of mountains in southeastern Arizona.

To the south and southeast of the Santa Catalinas an irregular but close-set series of mountains gives them a connection with the Mexican Cordillera which is much closer than their connection with the Rocky Mountains. To the west the nearest forest-clad elevations are the San Jacinto and San Bernardino Mountains of southern California, which are about 300 miles $(480 \mathrm{~km}$.) distant.

The relative isolation of the Santa Catalina Mountains and the directions in which they possess easy stages of connection with other elevated regions are of first importance in relation to the genesis and history of their flora, a subject which will be only briefly touched upon in this paper (see p. 36).

The southern face of the Santa Catalinas, to which the present investigation has been confined, is built solely of gneiss of varying degrees of hardness. The main ridge and the northern and eastern lateral ridges are worn into a relatively rounded topography, while the southwestern corner of the range possesses rock of greater durability and is correspondingly more rugged in topography. 
The highest elevations lie between Mount Lemmon (9,150 feet, 2,790 m.) and Green Mountain (7,900 feet, 2,410 m.), which are only 7 miles $(11 \mathrm{~km}$.) apart. Samaniego Ridge and Oracle Ridge extend northward from the vicinity of Mount Lemmon, falling rapidly in elevation and terminating in the high plain which lies in the direction of the Tortilla Mountains. A very rugged ridge extends southwestward from Mount Lemmon and terminates in Pusch Ridge. To the south of the main ridge an extensive elongated drainage basin has been developed which lies parallel to the south face of the range and finds its outlet through Sabino Cañon. Several important streams drain the south slopes of the main ridge and are tributary to Sabino Cañon. To the east of Sabino two important drainages-Bear Cañon and Soldier Cañon-drain the eastern end of the main ridge in the vicinity of Green Mountain, and west of Sabino are Pedregosa, Ventana, Pima, and other cañons which rise in the rugged southwestern portion of the mountain. All of these streams flow into the Rillito, a tributary of the Santa Cruz which also drains a portion of El Rincon range. The north face of the main ridge between Oracle and Samaniego ridges is drained by the Cañada del Oro, which flows at first north, then west, and finally southwest, emptying into the Santa Cruz. On the northeast slopes of the range the topography is relatively simple, the high elevations falling away rapidly in the direction of the San Pedro River. A large number of minor streams drain this region and give to the San Pedro perhaps less than one-fourth of the total run-off of the mountains.

The main drainageway of Sabino Cañon is the only one in the Santa Catalinas which possesses a constant flow of water, which is due both to the great extent of its cachment basin and to the fact that it has its source on the north slopes of Mount Lemmon in the heaviest body of timber on the mountain. In the Cañada del Oro, in Bear and Soldier Cañons, as well as in a few of the larger cañons of the north slopes, water may be found at all times of the year in certain localities where the local configuration of the valley or the occurrence of resistant dikes of rock forces the underflow to the surface. During the rainy seasons water may, of course, be found in any of the large drainageways. The heavy local showers of summer often convert even the smallest streamways into rushing torrents for a few hours.

The small size of the Santa Catalinas together with their elevation gives a steep gradient to all of the major streams. The main stream of Sabino Cañon falls from 7,700 feet at Webber's Cabin to 3,700 feet at the west end of Sabino Basin, a distance of 6 miles, or a gradient of fall of 667 feet per mile. From the west end of the Basin to its emergence onto the desert this stream falls only 1,000 feet in a distance of 5 miles. The Cañada del Oro falls at a rate of 494 feet to the mile from its source, just west of Mount Lemmon, to the confluence of its main tributary from the west slopes of the Oracle Ridge, and at the 
rate of 200 feet to the mile from there to its emergence from the mountain at 3,400 feet. The result of the passage of intermittent and torrential streams through such steep drainageways has been the wearing down of the stream beds to solid rock throughout almost the entire drainage system of the mountain. There are no parks nor mountain meadows, such as are present in some of the largest southwestern mountains. The flood-plains and alluvial bottoms are all small and scattered. The spots in which meandering streams may be found are very few indeed. In Bear Cañon a flood-plain nearly half a mile in length has been formed as a result of a large body of highly resistant rock, which has narrowed the cañon and prevented the outwash of erosion material. Similarly, in Soldier Cañon there is a small floodplain below which the stream falls 300 feet in a very short distance through a narrow gorge. Although Sabino Basin is a locality in which several converging streams undergo a sudden reduction in their gradient of fall, there has not been any considerable deposition at that place. On the contrary the region is one in which the streamways are bordered and bedded by large boulders in a matrix of coarse sand and are subjected to active scouring by the torrential floods of summer.

Whatever may have been the original form of the Santa Catalinas they have been so far worked upon by erosion and weathering that they now possess almost no relatively level areas or regions of indeterminate drainage. All of the higher portions of the main ridge and of the lateral ridges as well are extremely narrow. The only localities in which the topography broadens and is relatively level are at points where several drainages have their origin, or places just above precipitous cliffs. On the summit of Mount Lemmon there is a nearly level area of at least 100 acres (see plate $36 \mathrm{~A}$ and $\mathrm{B}$ ), from which a flat-topped ridge extends eastward for half a mile, terminating in an abrupt drop, in the course of which two narrow ridges have their origin. This restricted area of nearly level land is a last relic of a portion of the original structural form of the mountain, and it will not be many centuries until it is reduced to the narrow form of the lower ridges.

In the eastern and central portion of the Santa Catalinas the gneiss weathers readily and gives rise to a loam soil. The precipitate topography gives little opportunity for the accumulation of this soil, and it is thin in almost all localities. Throughout the lower portions of the range, below the pine forest, the soil has the appearance of being extremely coarse by reason of the surface coating of angular fragments from 1 to $5 \mathrm{~mm}$. in diameter. Surface drainage is able to move this material but slowly by reason of its size and angularity. Just beneath it may be found a fine soil, still mingled with coarse particles but held in place by the mulch of stones, which is analogous to "desert pavement." The outcropping rock and larger boulders serve to retard erosion and to preserve a soil sufficiently deep for shrubs and trees to 
find root. There are many deep soil-filled crevices through which the roots of trees are able to penetrate to bodies of deep-seated soil of favorable moisture content.

The restricted areas of alluvial soil in the desert and lower mountain regions are of a fine sand or sandy loam and possess considerable humus, in contrast to the soils of the slopes. At the forested elevations the soil is similar to that of the evergreen oak region. The soil of the lower pine belt is scarcely superior in depth or humus content to that of the upper oak region. Above 7,500 feet, however, the amount of humus, as well as the amount of surface litter, increases with the increasing density of the stand of pines. On the north-facing slopes which are clothed with fir forest the soil is not much if at all deeper than in the heavy stands of pine, but is notably richer in organic matter.

The alluvial slopes which immediately surround the mountain are so closely related to it in all of their physical and biological features that it will be necessary in the following pages to give some consideration to their vegetation. Throughout the arid southwest the long straight profiles presented by the outwash slopes of the hills and mountains form one of the characteristic features of the landscape. The distinct character of these slopes is to be attributed to the manner in which they have been laid down under conditions of torrential rainfall and of violent and intermittent stream flow, and their distinctness from the parabolic alluvial slopes of the humid regions has caused Tolman * to designate them technically by their popular Spanish name" bajada." $\dagger$

The bajadas constitute almost the total area of all the intermontane valleys of southern Arizona. The only portions of the valleys topographically separable from them are the stream beds, the flood-plains, and the "playas" or undrained areas into which one or more streams flow and deposit their load. To the student of vegetation there are marked differences between the upper and lower portions of all bajadas. The differences in the physical features presented by upper and lower bajadas of the same elevation have been only superficially investigated; the differences in their vegetation are very obvious, as will be described. The principal environmental features which appear to differentiate the high and low bajadas are the coarser character of the soil in the high bajadas, the possibility of higher soil moisture in them, at least at a depth of several feet, and the greater development of calcareous incrustations, or "caliche," in the soil of the low bajadas. The layers of caliche lie near the surface in some places, while in others the uppermost ones have been covered by deposition; they extend downwards for a few feet in some cases, or more frequently recur to a depth of 100 feet or more.

The bajada of the southern face of the Santa Catalinas has been

* Tolman, C. F. Erosion and Deposition in the Southern Arizona Bolson Region. Jour. Geol., vol. 17 , pp. 136-163, 1909.

$\dagger$ Pronounced bahada. 
truncated at its lower edge by the Rillito, which flows at right angles to the slope of the bajada, and on the western side of the range the Cañada del Oro has worn off the lower edges of the detrital slopes in similar matter. The well-developed bajadas which lie between Pima and Ventana Cañons fall at the grade of 150 to 175 feet per mile. Between Ventana and Bear Cañons the uppermost portion of the bajada has been worn away, so that at present a shallow valley lies between the base of the mountain and the lower portion of the old bajada, now cut into isolated and rounded hills. On the northeast side of the Santa Catalinas the bajada which extends down to the San Pedro River exhibits approximately the same grade as the bajada at Pima Cañon. Its surface is crossed, however, by so many drainages from the steep northeast face of the mountain that the bajada region consists of a series of rounded ridges extending out from the base of the mountain, very unlike the relatively flat bajadas of the Santa Rita and El Rincon ranges.

\section{VEGETATION OF THE SANTA CATALINA MOUNTAINS.}

The journey from the base to the summit of the Santa Catalina Mountains brings to the eyes of the observer a constantly changing panorama of vegetation. New types of plants are constantly being encountered with increase of altitude, while types already familiar are being left behind. There is no portion of the mountain, at least below 7,500 feet, in which a climb of 500 feet does not materially alter the physiognomy of the surrounding vegetation. The course of the vegetational panorama is not merely a gradual transition from the open desert of succulents and microphylls to the heavy fir forest which occupies the summit of Mount Lemmon (plate 1). There are interposed between these vegetations two distinct belts of plant life through which this tremendous transition takes place.

The arborescent cacti and the trees and shrubs of the desert give way gradually to evergreen oaks, leaf-succulents, sclerophyllous shrubs, and perennial grasses. This open but arborescent vegetation reaches a full development and then gives way to pine forest, with a distinctive accompanying carpet of herbaceous perennials. The pine forest is then, in turn, invaded by spruce and fir and the heavy stands of these trees are accompanied by still another assemblage of shrubs and herbaceous plants. The striking character of these gradations of vegetation is not due solely to the contrast between the varied vegetation of the open desert and the monotony of the closed coniferous forests, but is quite as largely due to the striking types of plants which are to be found both in the desert and in the region of evergreen oaks.

A first and most general observation of these vegetational stages will discover the distinctive regions of desert, of park-like semi-desert and of forest. The first is like the desert of the extensive bajada slopes which surround the entire mountain; the second is similar to plant 
communities which may be seen in southern Texas and in California, as well as in similar situations in Arizona and New Mexico; the last is essentially like the great body of yellow pine forest which stretches from southern Jalisco to British Columbia, or like the fir and Douglas spruce forests of the Rocky Mountains. These three major regions

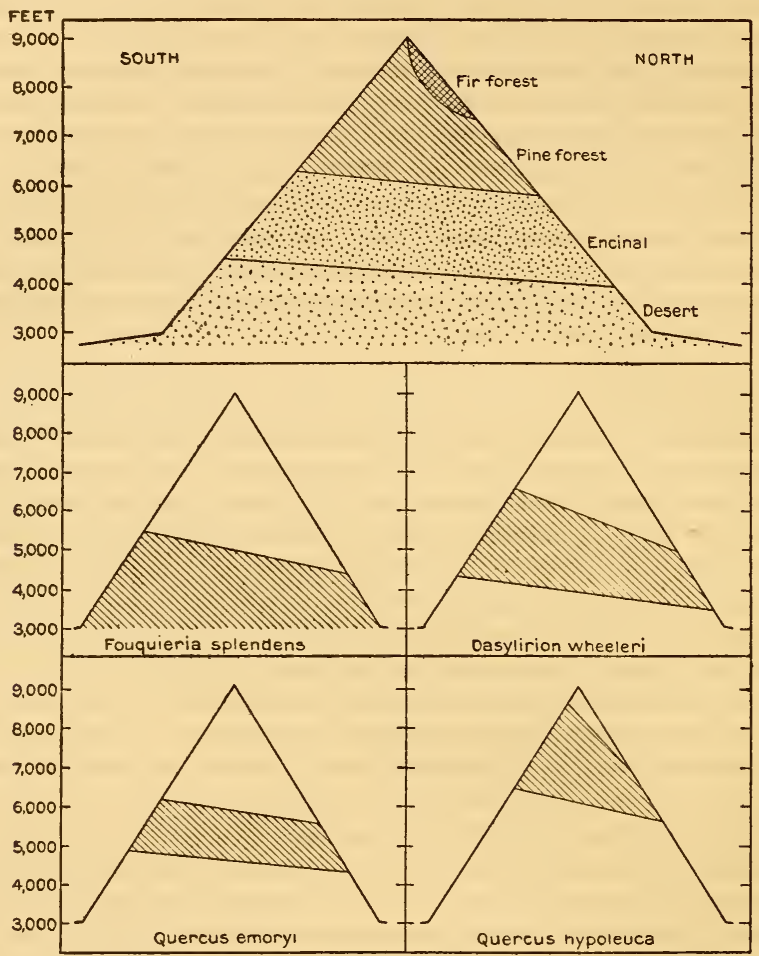

FIG. 1.-Diagram showing vertical distribution of Desert, Encinal, Pine Forest, and Fir Forest in relation to slope exposure, together with diagrams showing effect of slope exposure on vertical distribution of Fouquieria splendens, Dasylirion wheeleri, Quercus emoryi, and Quercus hypoleuca.

constitute the most natural and easily distinguished subdivisions of the vegetation, and depend for their distinctness on the radical dissimilarity of the dominant types of plants in each. They may best be designated by the simple terms Desert, Encinal,* and Forest. The

* The Spanish word "encinal" signifies a grove or forest of evergreen oaks, being derived from encina, evergreen oak. The suitability of the word was suggested by Prof. J. W. Harshberger. 
Encinal belt is essentially a region dominated by sclerophyllous trees and shrubs and by semi-succulent perennials, with an open stand of perennial grasses. It is what is designated by the Forest Service as the "woodland type" of forest. The pine and fir forests are very dissimilar in their floristic composition, but they are much more closely alike vegetistically than are any two of the three major divisions which have been made. A further and more careful examination of the stages which connect the Desert with the Forest will discover not only the inevitable gradations between the three major regions, but also several minor features which cause constantly recurring departures from the typical or ideal vertical distribution of the vegetation. The influence of slope exposure on the vertical ranges of both the individual species and the vegetation itself is a feature which these mountains share with almost all extra-tropical mountains; the distinctive vegetation of flood-plains and streamways is also as clearly noticeable here as in all arid and semi-arid regions; the occurrence of the lowland species at higher altitudes on ridges than in the valleys is also a strong differentiating feature.

In describing the salient physiognomic and floristic features of the vegetation, and its distributional behavior, it is expedient to recognize primarily the three major divisions of Desert, Encinal, and Forest, and then to take into account secondarily the degree to which the components of these regions intermingle and the extent to which the topographic irregularities of the mountain cause an alternation and interdigitation of the three regions.

The basal slopes of the mountain between 3,000 and 4,000 feet (915 and $1,220 \mathrm{~m}$.) present few vegetational distinctions from the upper bajadas, and almost no distinctions of flora. Between 4,000 and 5,000 feet $(1,220$ and $1,525 \mathrm{~m}$.) there is a rapid elimination of all but a very few of the characteristic desert species, and on north slopes at the latter elevation nearly all of the dominant Encinal forms have made their entry. The upper limit of the Desert may be placed at 4,000 feet for north slopes and 4,500 feet $(1,472 \mathrm{~m}$.) for south slopes. The upper edge of the Desert exhibits an attenuated occurrence of all of the larger desert plants and the presence of many perennial grasses and semiwoody plants which occurboth in the Encinal Region and on the bajadas of equal or slightly greater elevation in the neighboring portions of Arizona. The extreme upper limit of desert forms is 7,000 feet $(2,133$ m.), an elevation which is reached by a single succulent species. Following the dissimilarity of the lower and upper portions of the Desert Region they have been described separately.

The Encinal Region extends from the occurrence of the first extremely open groves of evergreen oaks on north slopes at 4,000 feet up to the first elevation at which the larger pines begin to dominate the physiognomy of the vegetation, at about 6,300 feet $(1,920 \mathrm{~m}$.) on south 
slopes. A few of the dominant species of the Encinal are found on the higher bajadas, above 3,500 feet $(1,067 \mathrm{~m}$.) elevation, but in the mountains none of its species is to be found so low as this except on north slopes or near arroyos of large drainage area. At 4,000 feet, on north slopes, several of the larger Encinal plants are encountered, and at 4,300 feet $(1,310 \mathrm{~m}$.), on north slopes, several additional dominant species are found. Within the Encinal Region it is possible to recognize a lower and an upper portion, distinguished chiefly by the openness of the former and the closed character of the latter. The closed Upper Encinal merges gradually into the Forest, losing some of its characteristic species at 6,000 to 6,300 feet $(1,830$ to $1,920 \mathrm{~m}$.), while others range to 7,800 feet $(2,380 \mathrm{~m}$.) and a few to 8,300 feet $(2,530 \mathrm{~m}$.) on south slopes.

The lowest occurrence of Forest is on north slopes at about 5,800 feet $(1,768 \mathrm{~m}$.) and on south slopes at about 6,300 feet $(1,920 \mathrm{~m}$.). The Forest is at first rather open and is superposed, as it were, upon the closed Encinal, but it becomes heavier and the Encinal elements within it become more sparse at elevations of from 6,300 to 6,800 feet (1,920 to $2,073 \mathrm{~m}$.), according to the slope exposure. The upper limit of Forest is not reached in the Santa Catalina Mountains at their highest elevation of 9,150 feet $(2,790 \mathrm{~m}$.), nor in the adjacent Pinaleno Mountains (Mount Graham) at 10,516 feet $(3,205 \mathrm{~m}$.). The forest of yellow pine occupies all south slopes up to the summit of Mount Lemmon. A forest dominated by fir, spruce, and Mexican white pine occupies the north slopes above 7,500 feet $(2,287 \mathrm{~m}$.), the earliest occurrence of these species being about 1,000 feet (305 m.) lower.

The description of vegetation which is given in the following pages applies only to the south face of the Santa Catalinas. The north face presents more abrupt slopes than the south, with most of its ridges running north from the main ridge. This circumstance obscures the influence of slope exposure, since it presents opposed slopes, facing east and west, which are identical in their vegetation.* Furthermore the north face of the range is mineralogically diversified, presenting exposures of shale, sandstone, limestone, diorite, and gneiss, whereas the south face presents an exposure of gneiss only, with a resultant mineral identity of soils from base to summit. It has thus been possible to carry out a study of climatic influences over a vertical gradient of 6,000 feet $(1,830 \mathrm{~m}$.) with uniform soil, and the east and west ridges of the south face have furnished opposed north and south slopes at all elevations.

* Differences between the vegetation of east and west slopes have been pointed out by Blumer for El Rincon Mountain, but the differences noted were of another character from those commonly existent between north and south slopes. See: Blumer, J. C. A Comparison between two Mountain Sides. The Plant World, 13: 134-140. 1910. 


\section{THE DESERT REGION.*}

Under the designation of "Desert" are comprised all those portions of the Santa Catalina Mountains in which the vegetation is open, low, and diversified in the assemblage of growth-forms, with a predominance of microphyllous trees and shrubs and an abundance of cacti. Such a vegetation is to be found covering the upper bajadas and extending up the slopes of the mountain to elevations of 4,000 to 4,500 feet (1,220 to $1,372 \mathrm{~m}$.), according to slope exposure. The vegetation of the Upper Bajadas will be described for the sake of the contrast which it affords with the vegetation of the upper portions of the mountain, as well as to give a picture of the plant life by which the mountain is surrounded and from which it has derived many of its characteristic species. The desert slopes of the mountain itself exhibit at first a close resemblance to the bajada, and then lose most of the larger bajada plants before the entry of the dominant plants of the Encinal region. This circumstance admits of a subdivision of the Desert region of the mountain into Lower Desert Slopes and Upper Desert Slopes. The latter region is much poorer than the former in cacti and much richer in grasses, both from the standpoints of the number of species and the number of individuals. The Upper Desert is similar in vegetation to many of the Upper Bajadas, such as those to the northwest of the Santa Catalinas and to the east and west of the Santa Rita Mountains, and might well be designated as "semi-desert" or "desert-grassland transition." It is, however, essentially similar to the desert plains in its vegetational make-up, and in no part of Arizona does it serve as a transition to true grassland. The largest cañons of the Santa Catalinas possess some plant communities that are radically unlike the vegetation of the desert itself, but not unlike the communities which surround the springs and wells of the desert plains. These are the groups of aquatic and palustrine plants which accompany the streams and pools of the cañons. The smaller cañons and arroyos $\dagger$ present distinctive features of vegetation, departing more and more from the large cañons and approaching more nearly the character of the desert areas away from water. All of these areas have been treated as a part of the Desert Region.

\section{THE UPPER BAJADAS.}

The Lower Bajadas of the Tucson region are covered by a vegetation in which Covillea tridentata (jediondia, creosote bush) is always the predominant plant and is often almost the sole plant of more than 2 feet in height over areas many square miles in extent. The plants which most commonly enter this community are Prosopis velutina (mesquite), Opuntia fulgida, Opuntia spinosior (both arborescent cylin-

\footnotetext{
* The word "region" is not here used in any of the technical senses in which it has been employed in phytogeography.

† The Spanish word arroyo is in common use in the southwestern United States to designate streamways which are usually without water.
} 
dropuntias), Opuntia toumeyi, Opuntia blakeana (procumbent platopuntias), and Acacia paucispina.

The shorter and steeper Upper Bajadas which fringe the southern and southwestern edge of the Santa Catalinas are clothed with a much more diversified vegetation, in all respects similar to that of other Upper Bajadas which lie below 3,500 feet $(1,067 \mathrm{~m}$.) in other localities in southwestern Arizona. The freedom of the soil from caliche is here, as elsewhere, responsible for the existence of a diversified vegetation rather than a pure stand of Covillea.

The Upper Bajadas, as exemplified along the south face of the Santa Catalinas at about 3,000 feet elevation $(915 \mathrm{~m}$.), bear what may be regarded in many respects as the most highly developed type of desert vegetation to be found in southern Arizona or northern Sonora. In the Upper Bajadas may be found a greater number of species of perennial plants than in any other distinctly desert situations. In them also the number of individual perennial plants per unit area is greater than in any areas outside the flood plains of such rivers as the Santa Cruz and Gila. The only areas that compare with the High Bajadas in these respects are the volcanic hills in which basaltic rock has weathered to a fine clay which is very retentive of soil moisture, as is well exemplified in Tumamoc Hill, the site of the Desert Laboratory. The andesitic and rhyolitic hills in the vicinity of Tumamoc are much poorer than it is in the number of individual plants per unit area, although perhaps nearly as rich in their flora.

On the Upper Bajadas there often occur, in almost equal admixture, from 15 to 25 perennial species of plants of such size as to dominate the physiognomy of the vegetation. These same species may be found on the more nearly level Lower Bajadas, but any one of them may often be absent for many miles, may be sporadically represented by a few individuals, or may occur in dense but local colonies (particularly in the case of the cacti). Occasionally as many as 5 to 10 of the species may be within sight at the same time.

The flora which characterizes the Upper Bajadas of the Santa Catalinas ranges without substantial loss down to sea-level on the gulf of California, ${ }^{*}$ and the vegetation formed by their commingling may be found as a belt covering the high bajadas which encircle all of the mountain ranges and clothing all of the low basaltic hills. A climb of 2 hours from the base of the Santa Catalinas will discover greater changes of vegetation and flora than can be encountered in the 150 miles $(242 \mathrm{~km}$.) between Tucson and Adair Bay.

The Upper Bajadas present the desert characteristics of openness of stand, lowness of stature, and commingling of diverse vegetation types. The first of these features is common to the vegetation of all

*See Hornaday,W.T. Camp Fires on Desert and Lava. New York, Scribner, 1909. MacDougal, D. T. Across Papagueria. The Plant World, 11: 93-99, 123-131, 1908. 
deserts, the last is at least characteristic of the less pronounced deserts of the southwestern United States and of Mexico. The openness of the stand is such that it is possible in all places to ride a horse through the vegetation and to take whatever course the rider may wish, with only occasional digressions of a few yards from the general direction of travel. The stature of the vegetation is such that it would be possible for the rider to keep almost constantly in view another mounted man half a mile distant. The columnar giant cacti reach a maximum height of 40 feet $(12 \mathrm{~m}$.) and the trees a height of 20 to 25 feet ( 6 to $8 \mathrm{~m}$.). The great bulk of the shrubs and succulents, however, are not more than 6 feet $(2 \mathrm{~m}$.) in height, and many of them are less than 4 feet $(1.2 \mathrm{~m}$.). Among the commonest vegetation types are stem-succulents, microphyllous and sclerophyllous trees and shrubs, macrophyllous deciduous shrubs, perennial grasses, and root-perennial and ephemeral herbaceous plants.

Largest and most conspicuous of the succulents is Carnegiea gigantea (saughuaro, giant cactus), which is here in its optimum habitat and very abundant (plate $3, \mathrm{~B}$ ). Among the microphyllous trees the most abundant are Prosopis velutina, Acacia greggii, Acacia paucispina, and the green-barked Parkinsonia microphylla (palo verde). The muchbranched arborescent types of cacti are represented by Opuntia versicolor, which attains a maximum height of 12 feet $(4 \mathrm{~m}$.), and by Opuntia fulgida and Opuntia mamillata (cholla), remarkable for the brilliance of their glistening straw-colored spines. Opuntia blakeana, Opuntia engelmanni, Opuntia toumeyi, and Opuntia discata are abundant representatives of the platopuntia group. The evergreen Covillea is greatly outnumbered by Fouquieria splendens (ocotillo). The globular Echinocactus wislizeni (bisnaga) attains a height of 4 feet $(1.3 \mathrm{~m}$.) with an even greater girth. Similar in form but never exceeding a foot in height are Echinocereus fendleri and Mamillaria grahami. The sclerophyllous Simmondsia californica (jojobe) and the relatively large-leaved deciduous Jatropha cardiophylla are frequent, while a large number of less striking shrubs are common, including Franseria deltoidea, Isocoma hartwegi, Encelia farinosa, Zizyphus lycioides var. canescens, Lycium torreyi, Momisia pallida, Krameria glandulosa, Trixis angustifolia var. latiuscula, Crassina pumila, and Psilostrophe cooperi.

The seasonal rains of winter and those of summer cause activity of foliation and growth on the part of all of the smaller shrubs. The winter rains cause foliation in Parkinsonia and Fouquieria, but not in Prosopis and the species of Acacia. Neither do they initiate growth in Parkinsonia, Fouquieria, nor any of the cacti. The two widely separated seasons of rain bring forth two wholly distinct sets of herbaceous ephemeral plants, at the same time that each season causes activity upon the part of some of the root-perennials. The ephemeral plants may form a dense carpet over both the Upper Bajadas and the Lower 
Bajadas in seasons of well-distributed and copious rainfall. With less favorable conditions they may form a very light cover or may be almost absent. The total flora of root-perennials and ephemerals is large, and the relative abundance of the various species fluctuates tremendously from spot to spot, and in the same spot it is by no means the same from year to year. This flora is nearly identical with that of the basaltic hills in the vicinity of Tucson, and has been fully listed by Thornber,* with a subdivision of vegetation types.

In the following list have been brought together the names of the most characteristic plants of the Upper Bajadas, grouped vegetistically and briefly described. Asterisks indicate the relative abundance of the species-three indicating that a plant is extremely common, two that it is very common, and one that it is fairly common. Figures follow the descriptions, indicating the average height of each species. A comparison of all the maximum heights given will convey an impression of the low stature of the commonest components of the vegetation.

Vegetistic Grouping of the Characteristic Species of the Upper Bajadas.

Perennial Non-succulent Trees and Shrubs:

*** Acacia greggii, microphyllous, winterdeciduous. 2 to $3 \mathrm{~m}$.

** Covillea tridentata, microphyllous, evergreen. 1 to $2.5 \mathrm{~m}$.

* Crossosoma bigelovii, sclerophyllous, evergreen. 1 to $1.5 \mathrm{~m}$.

* Ephedra trifurca, aphyllous, greenstemmed. 0.5 to $1 \mathrm{~m}$.

*** Fouquieria splendens, macrophyllous, drought-deciduous. 2 to $4 \mathrm{~m}$.

** Jatropha cardiophylla, macrophyllous, winter-deciduous. 0.5 to $1 \mathrm{~m}$.

* Kœberlinia spinosa, aphyllous, greenstemmed. 0.5 to $1 \mathrm{~m}$.

** Krameria glandulosa, microphyllous, evergreen. 1 to $2 \mathrm{~m}$.

** Lycium berlandieri, microphyllous, evergreen. 1 to $2 \mathrm{~m}$.

* Lycium fremontii, microphyllous, evergreen. 1 to $2 \mathrm{~m}$.

** Momisia pallida, sclerophyllous, evergreen. 1.5 to $2.5 \mathrm{~m}$.

* Olneya tesota, microphyllous, evergreen (foliage occasionally winterkilled). 3 to $6 \mathrm{~m}$.

*** Parkinsonia microphylla, microphyllous, drought-deciduous, greenstemmed. 2 to $5 \mathrm{~m}$.

*** Prosopis velutina, microphyllous, winter-deciduous. 3 to $6 \mathrm{~m}$.

** Zizyphus lycioides var. canescens, microphyllous, evergreen 1 to $2 \mathrm{~m}$.
Perennial Succulent Plants:

*** Carnegiea gigantea, columnar, branched. 5 to $14 \mathrm{~m}$.

** Echinocactus wislizeni, cylindrical. 0.5 to $1.5 \mathrm{~m}$.

** Echinocereus fendleri, cylindrical, cæspitose. 0.1 to $0.4 \mathrm{~m}$.

** Mamillaria grahami, cylindrical, solitary or cæspitose. 0.1 to $0.2 \mathrm{~m}$.

** Opuntia blakeana, flat-jointed, procumbent.

*** Opuntia discata, flat-jointed, procumbent or semi-erect.

** Opuntia fulgida, cylindrical-jointed, arborescent, 1 to $2 \mathrm{~m}$.

*** Opuntia mamillata, cylindricaljointed, arborescent. 1 to $2 \mathrm{~m}$.

** Opuntia toumeyi, flat-jointed, procumbent.

*** Opuntia versicolor, cylindrical-jointed, arborescent. 1 to $4 \mathrm{~m}$.

Perennial Shrublets (all less than 0.7 m. high):

* Coldenia canescens, sclerophyllous.

** Crassina pumila, dissected leaves.

*** Encelia farinosa, macrophyllous, slightly drought-deciduous.

*** Franseria deltoidea, sclerophyllous.

*** Isocoma hartwegi, dissected leaves.

*** Kalliandra eriophylla, dissected leaves.

** Psilostrophe cooperi, sclerophyllous.

* Trixis angustifolia var. latiuscula, sclerophyllous, slightly droughtdeciduous.

* Thornber, J. J. Vegetation Groups of the Desert Laboratory Domain. Carnegie Inst. Wash. Pub. 113, Chapter IV, 1909. 


\section{Ephemeral Summer-active Herbaceous Plants-Continued.}

Root Perennials (all facultative evergreens):

*** Abutilon incanum, sclerophyllous.

** Brodicea capitata var. pauciflora, bulbous, linear leaves.

** Cassia covesii, sclerophyllous, branched leaves.

* Dalea parryi, microphyllous.

*** Muhlenbergia porteri, semi-scandent.

** Pentstemon wrightii, macrophyllous.

** Perezia wrightii, macrophyllous.

** Verbena ciliata, macrophyllous, hairy. Ephemeral Summer-active Herbaceous Plants:

** Bahia absinthifolia.

*** Baileya multiradiata.

** Boerhaavia pterocarpa.

* Boerhaavia watsoni.

*** Bouteloua aristidoides.

*** Cladothrix lanuginosa.

** Euphorbia florida.

* Euphorbia melanadenia.
Ephemeral Summer-active Herbaceaus Plants:

Continued.

*** Pectis papposa.

*** Wedelia incarnata.

Ephemeral Winter-active Herbaceous Plants.

** Actinolepis lanosa.

** Anisolotus trispermus.

*** Baeria chrysostoma.

** Chorizanthe brevicornu.

** Cryptanthe intermedia.

* Eremocarya micrantha.

*** Gilia floccosa.

** Lepidium lasiocarpum.

** Lesquerella gordoni.

* Mentzelia albicaulis.

* Orthocarpus purpurascens.

** Pectocarya linearis.

*** Plantago fastigiata.

*** Plantago ignota.

\section{THE DESERT ARROYOS AND CAÑONS.}

In crossing the Upper Bajadas it is often possible to detect, by means of the vegetation, the approach to a very shallow drainageway through which water runs for only a few hours after the severest summer rains. The larger arroyos are still more conspicuous by reason of the still heavier stand of vegetation along their margins, and in the largest cañons is found the culmination of the influence of surface streams and underflows for the support of vegetation. The effect of the most transitory of the small streams is merely the raising of the moisture of adjacent soil to such a point that it will present favorable conditions for plant activity for a longer time after the close of the rainy periods than will the soil of the bajada in general. There is only a negligible and short-lived underflow in these smallest arroyos, and their only differences from the bajada are that in the rainy seasons they present slightly more favorable conditions with respect to soil moisture and that the effect of the rainy season is slightly prolonged in them, while the periods of drought are correspondingly shortened. In the larger arroyos there may not be a constant underflow, but there is at least a relatively high percentage of soil moisture for periods of sufficient length to greatly reduce the influence of the arid periods upon their plants. In the largest arroyos and in the mountain cañons themselves there is either a constant underflow, maintaining high moistures in the soil of the banks and bed of the arroyo, or else there is constant water, either running or standing in pools.

The smallest arroyos, which are very frequent on the Upper Bajada in the close proximity of the mountain, present no peculiar species, but merely a closer stand of the same plants that are to be observed throughout the bajada, notably Prosopis, Acacia greggii, and Momisia pallida. Along somewhat larger arroyos are to be found still heavier stands of the above species, together with Parkinsonia torreyana, Celtis 
reticulata, Baccharis sarothroides (batamote), Franseria ambrosioides, Lycium fremontii, Verbesina encelioides, and Bebbia juncea.

In the cañons and arroyos large enough to have a heavy flow of storm water but not large enough to have even pools of water which are constant throughout the year, there may be found several additional species of plants which also occur on the sandy flood-plains of the largest cañons. Prominent among these are Chilopsis linearis, Hymenoclea monogyra, and Baccharis glutinosa, all of which are large shrubs or in the case of Chilopsis may attain the size of small trees. Also characteristic of these sands are Franseria ambrosioides, Rumex hymenosepalus, Euphorbia pediculifera, Clematis ligusticifolia, and Calyptridium monandrum.

In the largest cañons of the south side of the Santa Catalinas it is possible to witness the occurrence of communities of mesophilous, palustrine, and aquatic plants which are limited in area but are made up of species which stand strongly in contrast with the predominant forms of the bajadas. The existence of streams and pools adjacent to rocky slopes makes it possible in several places for Callitriche and Isnardia to grow within 20 feet of Carnegiea and Fouquieria.

At the mouth of Soldier Cañon the rocky slopes of the streamway are clothed with typical bajada plants together with a few forms which are particularly abundant on cliffs and in rocky situations, both in the larger mountains of the region and in the volcanic hills. Among the latter are Opuntia bigelovii, Hyptis emoryi, Lippia wrightii, Anisacanthus thurberi, Encelia farinosa, Eriogonum wrightii, Chrysoma laricifolia, and Crossosoma bigelovii. Among the boulders bordering the streamway are Janusia gracilis, Plumbago scandens, Maurandia antirrhiniflora, Mimitanthe pilosa, and Stemodia plumieri, as well as occasional individuals of several species which are common away from streams at elevations of 4,000 to 5,000 feet, as, for example, Dasylirion wheeleri, Nolina microcarpa, Erythrina fabelliformis, Ingenhousia triloba, and Mimosa biuncifera. When the sands of the arroyo have not been recently scoured by floods they support scattered individuals of Amaranthus palmeri (celite), Cassia leptocarpa, Nicotiana trigonophylla, Bebbia juncea, Hymenoclea monogyra, Franseria xanthocarpa, Asclepias linifolia, Baccharis sarothroides, Mentzelia gracilenta, and Carduus sp.

In Ventana, Bear, and Sabino Cañons it is possible at all times of the year to find small colonies of palustrine and aquatic plants, and the vicinity of such localities is the optimum habitat for Prosopis and Populus. An underflow passes out at the mouth of Sabino Cañon which is heavier and more constant than that of any other cañon in the range; this gives Sabino Cañon its abundant mesophilous vegetation and also causes the arroyo through which its flood waters reach the Rillito to be occupied by a much richer stand of vegetation than is to be found along any of the arroyos of the adjacent region. The sandy and 
boulder-strewn bed is from 100 to 300 feet in width and the portions covered by the storm floods vary from season to season. Trees not only occupy the banks of the arroyo but occur scattered throughout its bed, where they may persist for many years, only to be eventually uprooted by some exceptionally severe freshet. Among these trees are Populus sp., Fraxinus toumeyi, Juglans major, Platanus wrightii, Sapindus drummondii, Prosopis velutina, and Sambucus mexicana, some of which reach a height of 50 to 60 feet (15 to $18 \mathrm{~m}$.). Such shrubs as Chilopsis linearis, Baccharis sarothroides, Baccharis glutinosa, and Hymenoclea monogyra are also common in and along this arroyo.

The floor of Sabino Cañon from its mouth to the Sabino Basin is occupied by an irregular and broken forest of Prosopis, Populus, Fraxinus, Platanus, and Salix (Salix wrightii and Salix sp.). Among these common trees are scattered a few individuals of three of the oaks characteristic of the Encinal region: Quercus oblongifolia, Quercus arizonica, and Quercus emoryi. These oaks occur near the mouth of the cañon at an elevation of 2,700 feet $(823 \mathrm{~m}$.), although their lowest occurrence on slopes, away from the proximity of an underflow, is at 4,200 to 4,500 feet (1,280 to $1,372 \mathrm{~m}$.). Cupressus arizonica occurs in the upper half of the cañon and in Sabino Basin at elevations above 3,200 feet $(975 \mathrm{~m}$.). It is confined to the proximity of streams up to an elevation of 6,000 feet, above which it is occasionally found on slopes.

The shrubby vegetation of the floor of Sabino Cañon includes all of the species which have been mentioned as occurring in the smaller cañons and arroyos, together with a number of shrubs and perennials which are more common along the arroyos and streams of the Encinal region. Among the latter are those species mentioned as occurring in Soldier Cañon and also Vitis arizonica, Bouvardia triphylla, Amorpha californica, and Brickellia californica.

Other characteristic plants are the shrubs Dodoncea viscosa var. angustifolia, Eysenhardtia orthocarpa, Indigofera sphcerocarpa, and the woody climber Nissolia schottii.

Among the herbaceous plants common in and along the pools and water-courses of Sabino Cañon may be mentioned:

Callitriche sp.

Carex sp.

Cerastium texanum.

Cyperus inflexus.

Helenium thurberi.

Hydrocotyle ranunculoides.

Isnardia palustris.

Juncus arizonicus.

Juncus bufonius.

Juncus interior.

Juncus sphcrocarpus.

Linaria canadensis.

Mecardonia peduncularis.
Mimulus langsdorfi.

Mimitanthe pilosa.

Montia perfoliata.

Myosurus cupulatus.

Phalaris intermedia.

Platystemon californicus.

Polygonum sp.

Senecio lemmoni.

Specularia biflora.

Stachys coccinea.

Stemodia durantifolia.

Tagetes lemmoni.

Tilloea erecta. 
THE LOWER DESERT SLOPES.

On leaving the uppermost edge of the bajada and commencing the ascent of the mountain over the rather abrupt slopes which lie between the larger cañons, a region is entered upon in which the physical conditions differ from those of the bajada chiefly in the pronounced slope exposure to the south, southwest, or southeast, and in the occurrence of large masses of rock in situ, with the coarse soil limited to small benches, pockets, and fissures. The vegetation of these lowest slopes is very similar to that of the Upper Bajadas, and is composed of a nearly identical flora. Prosopis, Parkinsonia, and Acacia are represented by smaller and less frequent individuals, and both the cylindropuntias and platopuntias occur somewhat less frequently. Carnegiea gigantea is even more abundant on the slopes than on the bajadas, being represented by smaller individuals, among which relatively few have reached the size at which branching begins. For Carnegiea and the above-mentioned trees the relatively rapid erosion of the soft gneiss and the shifting of the shallow soil are apparently too great to permit the attainment of great size or age. Fouquieria, Encelia, and Chrysoma laricifolia are even more abundant on the slopes than on the Upper Bajada, and Opuntia bigelovii, the most densely spiny of all the cylindropuntias, is found exclusively on southerly slopes and cliffs, in very rocky substratum, at elevations below 3,500 feet (1,067 m.). Olneya tesota and Covillea have not been detected on the mountain slopes (see plates 4 and 5).

The summer and winter ephemerals of the bajada are nearly all to be found on the Desert Slopes of the mountain, but rarely in such abundance as they attain on level ground. Among the most common of the ephemerals and root-perennials to be observed in the summer are Cladothrox lanuginosa, Pectis papposa, Euphorbia florida, Borhaavia pterocarpa, Bouteloua aristidoides, Andropogon saccharoides, Wedelia incarnata, Machoranthera tanacetifolia, Triodia mutica, Evolvulus arizonicus, Allionia gracillima, and Cassia covesii. The bases of boulders and partially shaded ledges of rock are the habitats of Selaginella rupincola, Cheilanthes lindheimeri, and Notholona hookeri. The ferns are not common and are conspicuous only during rainy periods, but the Selaginella is abundant here and becomes even more so at slightly higher elevations, where it frequently clothes the rocky walls of steep cañons to such an extent that their usual grayness is converted to a vivid green a few hours after a heavy rain (see plate 7 ).

The ascent from 3,500 to 4,000 feet $(1,067$ to $1,220 \mathrm{~m}$.) witnesses the first essential changes in the vegetation. At the latter elevation nearly all of the typical desert forms may be found, but Opuntia has become infrequent and Carnegiea gigantea, Echinocactus wislizeni, and Fouquieria splendens are conspicuously confined to southerly slopes (see plates 6 and 8). Parkinsonia torreyana, which is confined to arro- 
yos on the bajada, is found here growing with Parkinsonia microphylla, which it eventually exceeds in vertical distribution by nearly 500 feet (153 m.). Prosopis is even more abundant at 4,000 feet $(1,220 \mathrm{~m}$. than it is on the lowest slopes, and attains a trunk circumference of 6 feet $(2 \mathrm{~m}$.) at 4,200 feet elevation $(1,280 \mathrm{~m}$.), within 600 vertical feet $(183 \mathrm{~m}$.) of its upper limit. Such common shrubs of the bajada as Lycium, Zizyphus, Krameria, Jatropha, and Momisia are now very sporadic in their occurrence, and the compact, hemispherical and vividly green Chrysoma laricifolia has become very frequent and conspicuous, together with the white-tomentose Artemisia ludoviciana and the less conspicuous Eriogonum wrightii.

On northerly slopes, just below 4,000 feet (1,220 m.), are encountered the first individuals of the rosaceous tree Vauquelinia californica and of Agave palmeri and Dasylirion wheeleri (sotol). Along the arroyos the most conspicuous forms are Erythrina flabelliformis, the large leaves and brilliant scarlet flowers of which recall its tropical congeners, Manihot carthaginensis, with leaves of striking form, and Ingenhousia triloba (wild cotton), with tripartite leaves and large white flowers which strikingly resemble those of the cotton plant.

\section{THE UPPER DESERT SLOPES.}

The slopes lying between 4,000 and 4,500 feet (1,220 and 1,372 m.) constitute the upper edge of the desert. On these slopes all the characteristic species of the bajada are confined to southerly slopes, and all but half a dozen of them find their uppermost limits. On the Upper Desert slopes Vauquelinia becomes common, although confined to ledges of rock, and Juniperus pachyphloea, Quercus oblongifolia, and Quercus arizonica occur for the first time away from cañons. On the northerly slopes, where these trees form the lowest attenuated edge of the Encinal region, Dasylirion occurs in abundance together with the lowest individuals of Nolina microcarpa (bear grass), Arctostaphylos pungens (manzanita), Agave schottii, and Yucca macrocarpa.

The physiognomy of the Upper Desert slopes is made distinctive from that of the Lower Desert slopes not only by the entrance of these plants of striking form, and the exit of the desert species, but also by the abundance of perennial grasses, root-perennials, and small shrubs, which combine with the ephemeral plants, or their dead remains, to give a much more complete ground cover than is to be found in any part of the bajadas. The compact and extended patches of Agave schottii are an important element in this low cover, and so are the scattered plants of Bouteloua rothrockii and the bunches of Bouteloua curtipendula, Bouteloua oligostachya, Muhlenbergia dumosa, Andropogon scoparium, Eragrostis lugens, and Heteropogon contortus (see plates 8 and 9).

Commonest among the low shrubs and other perennials of the Upper Desert are: Chrysoma laricifolia, Acacia suffrutescens, Eriogonum 
wrightii, Dalea wistizeni, Calliandra eriophylla, Hymenopappus mexicanus, Artemisia ludoviciana, Dalea albiflora, Asclepias linifolia, Franseria tenuifolia, Baccharis thesioides, Ayenia microphylla, and Anisolotus argensis. The commonest summer ephemerals are Eriogonum abertianum and Eriocarpum gracile.

The flood-plains and the banks and beds of the arroyos in the Upper Desert are, in general, more like the arroyos of the desert in their vegetation than like those of the Encinal region. The largest tributaries of Sabino Cañon are somewhat less rich in aquatic and palustrine plants than the lower portion of the cañon, and merely because of their steeper gradient and less regular flow. The forest which occupies the flood-plains of Sabino Basin is chiefly made up of Quercus emoryi, Quercus arizonica, Platanus wrightii, and Cupressus arizonica. The smaller flood-plains and arroyos of the Upper Desert have few of these trees but occasional individuals of Populus and open thickets of Baccharis emoryi and Baccharis sarothroides, together with Franseria ambrosioides, Ingenhousia triloba, Erythrina flabelliformis, Croton texensis, Calliandra eriophylla, Brickellia californica, Gymnosperma corymbosa, Amorpha californica, Bouvardia triphylla, and Stachys coccinea (see plate 10A).

\section{THE ENCINAL REGION.}

Some of the distinctive species of the Lower Encinal are found at 4,000 feet and other forms, characteristic of the Upper Encinal, extend upward into the Forest Region as far as 8,000 to 8,600 feet. The Lower Encinal may be said to have its commencement, however, in the open orchardlike stands of Quercus oblongifolia and Quercus arizonica, which occupy northerly slopes at about 4,300 feet. At an approximate elevation of 5,000 feet the open Encinal may be found on all slopes except the steepest southerly ones, while on steep northern slopes it already forms nearly closed stands. The dense stands of the Upper Encinal region begin to appear on southerly slopes at about 5,800 feet, and persist to the elevation of 6,200 to 6,400 feet, where large pines begin to dominate the physiognomy and the true forest may be said to begin.

The activities of growth and flowering which are so conspicuous on the Desert in the season of winter rains are very much reduced in the Lower Encinal and are practically absent in the Upper Encinal. Leaves are retained by the evergreen oaks and the sclerophyllous shrubs throughout the winter and are shed in April or May, simultaneously with the first growth of shoots and the renewal of foliage. Extremely few of the ephemerals which often carpet the Desert in January are to be found in the Encinal region. There is some activity on the part of root perennials in the Lower Encinal during the months of March and April, and flowers may be found on species of Sphceralcea, Calochortus, Verbena, Pentstemon, Eriogonum, and Lesquerella. Such activity is commonly stopped by the advent of the arid fore-summer, and 
relatively little activity is observable in May and June, at least away from arroyos and springs. In the Upper Encinal the early months of spring partake of the rest which is then predominant in the Forest region. The deciduous trees begin foliation in late April or early May and some of the root perennials are not far behind them in their earliest activity. The duration of the arid fore-summer being slightly less in the Upper Encinal than in the Lower Encinal, and its intensity being also less, there is not so decided a break, among the herbaceous perennials between the first activity of spring and that of the humid midsummer, as there is in the Lower Encinal and the Desert.

THE LOWER ENCINAL.

The species which chiefly characterize the Lower Encinal at its desert edge have already been mentioned: Quercus oblongifolia, Quercus arizonica, Juniperus, Vauquelinia, Dasylirion, Nolina, Yucca macrocarpa, Arctostaphylos pungens, Agave palmeri, and Agave schottii. All of these are much more abundant at 5,000 feet than at 4,500 except Quercus oblongifolia, which is a tree of very narrow vertical range, rarely occurring above 5,200 feet and reaching its limit at 5,600 feet on steep south slopes. At 5,000 feet the Encinal has been augmented by the appearance of the common trees Quercus emoryi and Pinus cembroides (piñon) and by the shrubs Garrya wrightii, Mimosa biuncifera, Rhus trilobata, and Rhamnus crocea var. pilosa (see plates $11_{\mathrm{A}}, 15$, and 16).

The only characteristic Desert species which persist throughout the Lower Encinal are: Carnegiea gigantea, a single young individual of which has been seen at 5,100 feet; Opuntia versicolor, which reaches 5,500 feet; Fouquieria and Echinocactus wistizeni, which reach 5,600 to 5,800 feet; and Mamillaria grahami, which ascends to 7,000 feet. So far as known, no other plants occurring on the Bajadas or in any of the other non-palustrine desert habitats range to elevations above 6,000 feet.* There are at least a few species found in cañons and near constant water which range from the elevation of the Desert to more than 6,000 feet. Several of the typical desert genera are represented at higher elevations by species which seldom range as low as the Upper Desert region. Two species of Opuntia (platopuntias) are found throughout the Encinal, growing in thin soil or on rocks, and reaching their highest occurrence solely on ridges or upper slopes. One of these species has been found on a sharp rocky ridge at 7,200 feet, which is the highest known occurrence of a platopuntia in the Santa Catalinas. Mamillaria arizonica ranges from the Upper Desert to nearly 7,000 feet; Echinocereus polyacanthos ranges from about 5,000 feet to 7,800 feet, which is the highest elevation at which any cactus has been found in these mountains. Agave palmeri and Yucca schottii are also fre-

* This statement is made only with respect to the Santa Catalinas. The influence of the character of the underlying rock and of the elevation of the surrounding desert each serves to determine indirectly the vertical limits of desert species. 
quently found up to elevations of 7,000 to 7,200 feet, and the latter reaches its uppermost limit at 7,800 feet (see p. 30).

The ground cover of low perennial plants, grasses, succulents, and herbaceous species which has been mentioned as characterizing the Upper Desert is likewise to be found throughout the Lower Encinal, but does not form as close a carpet in the latter region as it does in the former (see plates 12,15, and 16). Throughout the year this irregular carpet does much to lend character to the landscape, varying but little in its density with the alternating seasons of vegetative activity and of drought rest. The scattered polsters of Chrysoma laricifolia are green at all seasons, and there is no change in the gray-green foliage of Eriogonum wrightii nor in the white tomentose leaves of Artemisia ludoviciana. The perennial grasses, many of the other perennial herbaceous plants, and all of the ephemerals are either in a resting state or dead throughout the arid fore-summer and the arid after-summer, but the only change which their rest or death registers in the landscape is a change of its color tone from a greenish gray to an almost uniform gray and grayish brown.

All of the low shrubs and root perennials which were mentioned as characteristic of the Upper Desert are to be found occasionally or commonly in the Lower Encinal, excepting Franseria tenuifolia and Ayenia microphylla. The winter and spring ephemerals are extremely few at 4,500 to 5,000 feet, but there is much activity of growth and much blooming among the root perennials and low shrubs during the months of February and March, and sometimes during the early part of April. The humid mid-summer is a season of even greater activity on the part of the smaller elements of the vegetation. Relatively few of the conspicuous herbaceous plants which are active at 5,000 feet in the mid-summer have extended upward from the bajada, and the number of summer ephemeral species is very small as compared with the Desert.

Among the small shrubs, root perennials and other herbaceous plants which are common during the humid mid-summer at 4,500 to 5,500 feet, in the Lower Encinal, may be mentioned:

\footnotetext{
Baccharis pteronoides.

Baccharis thesioides.

Bouteloua hirsuta.

Bouteloua rothrockii.

Castilleja integra.

Cordylanthus wrightii.

Crotalaria lupulina.

Dalea albiflora.

Dalea wislizeni.

Eriocarpum gracile.
}

$\mid \begin{aligned} & \text { Eriogonum pharnaceoides. } \\ & \text { Euphorbia heterophylla. } \\ & \text { Gilia multiflora. } \\ & \text { Gnaphalium wrightii. } \\ & \text { Hymenothrix wrightii. } \\ & \text { Linum neomexicanum. } \\ & \text { Muhlenbergia gracillima. } \\ & \text { Pappophorum wrightii. } \\ & \text { Pentstemon palmeri. } \\ & \text { Phaseolus wrightii. }\end{aligned}$

On the flood-plains and along the streamways of the Lower Encinal may be found a greater number of individuals of the evergreen oaks than on the surrounding slopes (see plate 10B), and also Juglans major, Platanus wrightii, and Populus sp., not to mention the restricted occurrence of Cupressus arizonica. Shrubs occasionally found along the 
arroyos are Rhus trilobata, Baccharis emoryi, Erythrina flabelliformis, Bouvardia triphylla, Amorpha californica, Fendlera rupicola, Morus celtidifolia, and the climber Vitis arizonica.

On the flood-plains of the larger cañons in the Lower Encinal may be found the lowest examples of several species which become common in the forested region of the mountain, and these are indeed the lowest members of the forest flora, if aquatics are excepted. At 4,900 feet Ceanothus fendleri and Prunus virens are both to be found, growing not only on a flood-plain but in the shade of evergreen oaks. Berberis wilcoxii is found at 5,200 feet growing in shade near a constant spring, and Rhamnus ursina is infrequent at 5,000 feet near streamways.

During the mid-summer there is an abundant stand of herbaceous perennials and ephemerals on the flood-plains of the Lower Encinal, giving them a much closer carpet of vegetation than is to be found on the adjacent slopes. Abundant and characteristic among them are:

\author{
Artemisia sp. \\ Asclepias tuberosa. \\ Brickellia californica. \\ Castilleja integra. \\ Chamocrista leptadenia. \\ Comandra pallida. \\ Cordylanthus wrightii. \\ Crotalaria lupulina. \\ Diodia teres. \\ Eriocarpum gracile.
}

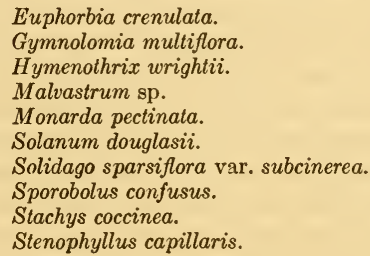

\section{THE UPPER ENCINAL.}

During the ascent from 5,000 to 6,000 feet the most notable change in the vegetation is the gradual increase in the density of the stand of evergreen trees and shrubs (see plates 18, 19, and 20), a change which forms the chief distinction of the Upper Encinal from the Lower Encinal. Quercus emoryi and Quercus arizonica are still the dominant trees, while Pinus cembroides and Juniperus pachyphloea are somewhat less common. Arctostaphylos pungens and Garrya wrightii are the most common of the larger shrubs and Mimosa biuncifera of the smaller ones. Dasylirion wheeleri, Nolina microcarpa, and Agave palmeri remain abundant, at least on southern slopes, up to 6,000 feet and Agave schottii remains common up to its upper limit at that elevation. With the increasing abundance of the oaks, however, these semi-desert species as well as the cacti become infrequent and are confined to the summits of ridges and the crevices of rocks.

On steep north slopes, between 5,300 and 6,000 feet, many almost pure stands of Pinus cembroides are to be found and also the lowest individuals of Quercus reticulata, here a low-branched tree of 20 feet in height. Pinus chihuahuana first appears at about 5,900 feet on south slopes, being the only one of the trees which is not found at much lower elevations on north slopes than on south ones-indeed it is not common on north slopes at any elevation. 
The heaviest stands of the Upper Encinal constitute a relatively dense thicket in which the trees are from 18 to 30 feet in height and so closely placed that it is very difficult for a mounted man to make his way among them. This is partly due to the fact that the oaks, the juniper, and the piñion all branch freely from a point near the ground, and partly to the size and hemispherical habit. of Arctostaphylos, in which many of the stiff branches are placed in a nearly horizontal position near the ground. These dense stands of the Upper Encinal, between 5,600 and 6,200 feet, are made up of the same species that form the very open Lower Encinal in so far as concerns the trees, shrubs and larger perennials. There are, however, many root-perennial herbaceous plants in the Upper Encinal which are not to be found below 5,500 feet, nearly all of which extend upward into the lower portions of the Forest region.

Quercus emoryi is still a common tree at 5,600 feet, Quercus arizonica is replaced by the closely similar Quercus reticulata, Quercus hypoleuca makes its first appearance, and Juniperus pachyphloa and Pinus cembroides reach their maximum abundance between 5,500 and 6,500 feet. Dasylirion, Nolina, and Yucca are still conspicuous elements of the vegetation even in the most dense stands of oaks, but Agave schottii is no longer found and Agave palmeri, like the cacti, is found only on ridges and rocks. A common tree of the lower forest region, Arbutus arizonica, is first found in the Upper Encinal, where its isolated individuals are conspicuously different from the oaks. The only trees of the mountain, excepting the desert species, the ranges of which lie wholly below the Upper Encinal, are Vauquelinia californica and Quercus oblongifolia, while Quercus arizonica reaches its upper limit in this region.

Phoradendron californicum, the mistletoe, which so commonly infests Prosopis and the other trees of the desert, is found throughout the Desert region of the mountains, while in the Encinal Phoradendron flavescens var. villosum is found on several hosts and Phoradendron juniperinum is extremely common on Juniperus, but does not extend with it to its highest occurrences.

The vegetation of the Upper Encinal is extremely poor in shrubs of the type so common in the Upper Desert and still frequent in the Lower Encinal. In the open spots there may be found a few individuals of Artemisia ludoviciana, Parosela wislizeni, Anisolotus argensis, and other dwarf shrubs of the Lower Encinal, while in the shade of the heaviest stands of oaks are to be seen Pteris aquilina var. pubescens, Muhlenbergia affinis, Polygala alba, Comandra pallida, Hymenopappus mexicanus, Cordylanthus wrightii, Chenopodium fremontii, and other species of root-perennials. The vegetation of rocks and exposed ridges is still suggestive of the desert, both in its physiognomy and in its phyletic relationships. In the crevices of rocks, where the amount of soil is extremely scant and the supply of moisture must 
be very uncertain, Laphamia lemmoni is found, a small composite known only from the Encinal region and only from this habitat. In crevices more favorably situated with respect to moisture may be found Heuchera sanguinea, and on north slopes at 6,000 feet, in moist crevices, may be found the lowest colonies of Saxifraga eriophora, a plant which occurs infrequently up to the summit of the mountain.

Beds of Selaginella rupincola are still to be found at 6,000 feet and the several species of drought-resistant ferns, which are confined to the shade of rocks at lower elevations, are common on the floor of the heavy stands of Pinus cembroides, or grow among the boulders in more open situations. Among these the most common are: Cheilanthes fendleri, Notholcena sinuata, Notholcena ferruginea, and Gymnopterishispida. None of these species extend upward into the Forest region (see plate 14).

The drier flood-plains and arroyos of the Upper Encinal are characterized by the same oaks and evergreen conifers that occur on the adjacent slopes, while the moister streamways bear a number of deciduous trees and shrubs, notably Juglans rupestris and Platanus wrightii, extending upward from streamways at lower elevations, and Prunus virens, Rhamnus ursina, Rhus trilobata, Robinia neomexicana, and Rhus elegantula. Less frequent are Ceanothus fendleri, Berberis wilcoxii, and Bouvardia triphylla, and Vitis arizonica is still common. Pinus chihuahuana is not infrequent along the drier arroyos at the lower edge of its range, and Cupressus arizonica is found along the streams and on the lower slopes of Sabino and Bear Cañons and some of their tributaries.

The commonest herbaceous perennials of the flood-plains of the Upper Encinal are:

Apocynum sp.

Artemisia dracunculoides.

Asclepias tuberosa.

Carduus rothrockii.

Euphorbia crenulata.

Geranium caspitosum.

Gomphocarpus hypoleucus.

Gymnolomia multiflora.

Monarda pectinata nutt.

Muhlenbergia sp.
Oenothera sp.

Pentstemon torreyi.

Picradenia biennis.

Pteris aquilina var. pubescens.

Rubus oligospermus.

Senecio neomexicanus.

Solidago sparsiflora var. subcinerea.

Sporobolus confusus.

Thalictrum fendleri var. wrightii.

Zauschneria californica.

\section{THE FOREST REGION.}

One of the most striking changes encountered in the vegetational gradient of the Santa Catalinas is that from the closed and relatively low Encinal to the open forest of Pinus arizonica, with trees 50 to 60 feet in height. This pine, the Arizona yellow pine, is closely related to Pinus ponderosa, the western yellow pine, and is the common tree of the forested altitudes of the mountain, extending upward on southerly slopes to the summit of Mount Lemmon. The lowest stands of pine which possess sufficient density to be regarded as forest occur on northerly slopes at 5,800 to 6,000 feet, or on southerly slopes at 6,000 to 6,400 feet, the limits depending in each particular locality upon the 
steepness of the slope and its soil characteristics, particularly with respect to the soil moisture supply (see plate 21 ).

Much more gradual and inconspicuous is the transition from the Pine Forest to that in which Abies concolor (white fir) is the dominant tree. This type of Forest occupies the northern slopes of the highest summits and ridges of the range from 7,500 feet upward, but there are no elevations in the Santa Catalinas sufficiently great to bring the Fir Forest onto the south slopes.

Throughout the Pine Forest there are trees, shrubs, and herbaceous plants which may be found in the Encinal, at least in its upper portion, but only in the lowest edge of the Pine Forest may plants be found which suggest the genera or vegetation types characteristic of the desert. A single cactus (Echinocereus polyacanthos), a $Y u c c a$, and an Agave are the sole representatives of the succulent and semi-succulent forms of the lower elevations, and they are rare above 7,000 feet and absent above 7,800 feet.

The Pine Forest is not, however, without vegetational features which suggest the effects of a climate not far removed in character from that of the desert. The openness of the lowest stands of Pinus arizonica, the high mortality among the seedlings of the pine, the character of the foliage of the shrubs and herbaceous perennials, and the deep-seated root systems of the latter plants, all point to the existence of a precarious soil-moisture supply and to atmospheric conditions conducive to active transpiration. In the Fir Forest none of these features is observable, and the vegetation as a whole presents a much more mesophilous aspect.

In the Forest region the winter is a season of almost absolute rest, save for the photosynthetic activity which is doubtless carried on by the conifers, and possibly by the evergreen oaks and shrubs. The deciduous trees and shrubs are leafless from early or mid October until April or May, and only a few herbaceous perennials are active during this period, such as the evergreen species of Pyrola and the early vernal plants, such as Frasera. The amount of activity on the part of the perennial herbaceous plants during the arid fore-summer is largely dependent on the amount of winter precipitation and the date of its termination. In the lower portion of the Pine Forest it often happens that almost all activity is in abeyance until the first rains of the humid mid-summer, while in the upper Pine Forest and in the Fir Forest it is always possible to find a majority of the common herbaceous plants in activity in May and June. There is a notable scarcity of annual plants above 6,000 feet, and the only ones that have been detected in the Forest region are:

Androsace arizonica.

Bidens sp.

Cerastium sericeum.

Dalea polygonoides.

Drymaria sperguloides.

Drymeria tenella.

Muhlenbergia sp. 
THE PINE FOREST.

In the lowest stands of Pine Forest many of the dominant Encinal forms are still to be found, but in no case do the evergreen oaks fail to become more and more scattered in occurrence as the forest of pines becomes more dense. Quercus emoryi and Pinus cembroides are scarcely concerned in the overlapping of the Chaparral and Forest, as the former reaches its upper limit at 6,300 feet, while the latter becomes confined to the rocky non-forested or lightly forested ridges at about the same elevation, although it persists as a rare shrub to an elevation of 7,800 feet. Arctostaphylos and Garrya are likewise of infrequent occurrence in stands of forest. The oaks which are characteristic of the closed forest are Quercus reticulata and Quercus hypoleuca. The former is commonly a low-branching shrub which often forms thickets on the steep slopes of the highest peaks, where it extends upward to about 8,600 feet. The latter oak is a shrub near its lower and upper limits at 6,000 and 8,500 feet respectively, but attains a height of 40 feet and a girth of 3 to 4 feet between 6,500 and 7,500 feet. Juniperus pachyphloea is of occasional occurrence in the Forest up to 7,900 feet, and Arbutus arizonica (Arizona madroña), at first infrequent, becomes common at 7,000 to 7,500 feet and reaches its upper limit at 7,800 to 8,000 feet.

The composition of the Forest itself is extremely simple from its lower limit around 6,000 feet to 7,500 feet, and above that elevation is equally simple on southerly slopes up to the summit of Mount Lemmon. Pinus chihuahuana reaches its limit at about 6,700 feet and forms a very inconsiderable portion of the forest throughout the uppermost 500 feet of its vertical range. Pseudotsuga mucronata begins to occur on steep northerly slopes at 6,100 feet and Pinus strobiformis (Mexican white pine) at 6,800 to 7,000 feet, but neither begins to affect the composition of the Forest in general until higher elevations are reached. At 6,000 feet the streamways and flood-plains are characterized by several deciduous trees in addition to the pines themselves. Platanus wrightii is near its upper limit at this elevation, Juglans rupestris, Prunus virens, and Acer interior are of frequent occurrence, while at 6,500 to 6,800 feet are found the lowest individuals of Quercus submollis and Alnus acuminata.

Throughout the Pine Forest are to be found a large number of herbaceous perennials, a few of which occur in the Upper Encinal, the great majority of which, however, accompany the closed stands of pine, with additions and eliminations with increasing altitude. In addition to these plants is another large group which is confined in occurrence to the near proximity of streams and streamways; some of the members of the group being thus restricted in occurrence at lower altitudes, while they are of more general occurrence on heavily wooded slopes at higher elevations.

In the clear park-like stretches of Pine Forest where no evergreen oaks happen to occur, the most conspicuous plants on the forest floor 
are the low thorny shrub Ceanothus fendleri, or varieties of it, and the bunch-grass Muhlenbergia virescens. The commonest of the herbaceous perennials are low, small plants such as Hedeoma hyssopifolia, Houstonia wrightii, Poa fendleriana, Calliandra reticulata, and Calliandra humilis, or else they are somewhat taller but relatively inconspicuous, as Pseudocymopterus montanus var. tenuifolius, Erigeron neomexicanus, Lithospermum multiflorum, Lotus puberulus, and others. In the dense shade of the Upper Encinal Pteris aquilina var. pubescens is common, and it again becomes common in the pines above 7,500 feet, but is infrequent in the lower portion of the forest region.

The Pine Forest gives the impression of possessing a much richer flora of herbaceous plants than is found in any other habitat of the mountain. This impression is due to the fact that a large number of species enter into the vegetation as very common components of it. As there are almost no rare or infrequent species to be found in the Pine Forest away from streams and springs, the total flora involved is not so great as might be supposed on first examination. Following is a list of the characteristic species found between 7,000 and 8,000 feet, the relative abundance of which is indicated by asterisks:

Characteristic Herbaceous Plants of the Pine Forest.

\footnotetext{
*** Achillea lanulosa.

* Agastache pallidiflora.

** Anisolotus puberulus.

** Antennaria marginata.

* Anthericum torreyi.

*** A pocynum scopulorum.

* Bidens sp.

** Brickellia grandiflora.

*** Calliandra reticulata.

** Carpochote bigelovii.

*** Castilleja gloriosa.

*** Cologania longifolia.

** Commelina dianthifolia.

* Desmodium arizonicum.

* Desmodium grahami.

*** Dugaldia hoopesii.

*** Erigeron macranthus.

*** Erigeron neomexicanus.

** Eupatorium arizonicum.

* Eupatorium pauperculum.

* Eupatorium rothrockii.

** Geranium cospitosum.

** Gilia thurberi.

** Gnaphalium decurrens.

** Gnaphalium wrightii.

** Gomphocarpus hypoleucus.

*** Hedeoma hyssopifolia.

** Hieracium discolor.

*** Houstonia wrightii.

*** Hymenopappus mexicanus.

* I pomoea muricata.

*** Kaleria cristata.
}

*** Lathyrus graminifolius.

*** Lithospermum multiflorum.

*** Lupinus sp.

** Microstylis montana.

*** Monarda pectinata.

** Monarda scabra.

*** Muhlenbergia virescens.

* Muhlenbergia sp.

** Oenothera hookeri.

** Onosmodium thurberi.

** Panicum bulbosum.

** Pentstemon torreyi.

** Perityle coronopifolia.

** Phaseolus retusus.

** Pinaropappus foliosus.

*** Poa fendleriana.

*** Potentilla subviscosa.

*** Pseudocymopterus montanus var. tenuifolius.

*** Pseudocymopterus montanus var. purpureus.

*** Pleris aquilina var. pubescens.

* Salvia arizonica.

*** Senecio neomexicanus.

*** Solidago bigelovii.

*** Solidago marshallii.

*** Stevia sp.

* Tradescantia pinetorum.

** Trifolium pinetorum.

** Vicia americana.

** Woodsia mexicana. 
The pure or nearly pure stands of Pinus arizonica which occur between 8,000 and 9,000 feet are increasingly poor in the evergreen oak shrubs, which have disappeared at the latter altitude. The clumps of young Quercus submollis give the forest its only deciduous element at this altitude, and the low patches of Ceanothus, so common at 8,000 feet, give way at 9,000 feet to Symphoricarpos oreophilus and to the much less frequent Holodiscus dumosus. Very many of the commonest herbaceous perennials of the Pine Forests which lie between 7,000 and 8,000 feet do not reach 9,000 feet, or are replaced in the physiognomy of the forest by closely related species. On the summit and southern slopes of Mount Lemmon the commonest herbaceous plants are: Koleria cristata, Dugaldia hoopesii, Erigeron neomexicanum, Pteris aquilina var. pubescens, Gnaphalium decurrens, Hieracium lemmoni, Senecio sp., Antennaria marginata, Silene greggii, and Helianthella arizonica. Throughout the higher Pine Forest Arceuthobium divaricatum and Arceuthobium robustum are common on the trunks and limbs of Pinus arizonica.

At about 6,800 feet Alnus acuminata, Acer interior, and Quercus submollis become frequent along streams (see plates 30 and 31 ). The first two are confined to this habitat throughout their vertical range, while the oak, which is the only deciduous member of the genus in these mountains, is found even in some of the driest situations above 7,600 feet. Quercus submollis occurs characteristically either as single trees of considerable size, up to 40 feet in height and 4 feet in girth, or else as crowded circumscribed groups of young trees, which doubtless owe their juxtaposition to the accidents of seed dispersal. Salix taxifolia is also a common streamside shrub above 6,800 feet, and in certain portions of the mountain Rosa fendleri is abundant in the proximity of streams.

Herbaceous plants are to be found in increasing numbers at or near the banks of streams between 6,000 and 7,400 feet. Prominent among them are: Juncus arizonicus, Aquilegia chrysantha, Thalictrum fendleri var. wrightii, Scrophularia sp., Trifolium pinetorum, Fragaria ovalis, Potentilla thurberi, Hypericum formosum, Lobelia gruina, Agrimonia brittoniana var. occidentalis, Gaura suffulta, and Tagetes lemmoni.

THE FIR FOREST.

Between 7,000 and 7,400 feet is a rapid change in the character of the forest stands on northerly slopes, due to the increasing occurrence of Pseudotsuga mucronata and Pinus strobiformis, the lower limits of which have already been mentioned, and to the appearance of Abies concolor. These three species occur in mixed stands together with Pinus arizonica on northerly slopes up to about 7,500 feet, above which elevation the latter becomes a very infrequent tree on slopes facing directly north, although it still occurs in admixture with Pseudotsuga 
and Abies at 9,000 feet on eastern and western exposures. Above 7,500 feet Pinus strobiformis ceases to be confined to the proximity of streams, and occurs in admixture with Pseudotsuga and Abies, but is not so common as they in the heaviest stands of this type of forest. On the north slopes of Mount Lemmon is a small colony of Abies arizonica. which is not known from any other locality on the mountain.

Slopes of due south or southwestern exposure are held by Pinus arizonica up to the summit of Mount Lemmon at 9,150 feet, with a slight occurrence of Pseudotsuga and Pinus strobiformis above 8,000 feet. The Pseudotsuga and Abies forest is found in fine development at 7,500 feet on steep north exposures, and reaches its maximum development in stature and size of the trees on the north slopes of Mount Lemmon at 8,500 to 9,100 feet (see plates 1 and 35). The altitude of the Santa Catalina Mountains is nowhere sufficient to admit of the occurrence of extended bodies of such forest, nor of their existence on southerly slopes.

In the Fir Forest the last relicts of the Encinal have disappeared: Quercus hypoleuca, Quercus reticulata, and Juniperus pachyphloea are nowhere to be found in association with Pseudotsuga and Abies, although they may grow very near them on opposed slopes. Arbutus arizonica, which is more common in the Pine Forest than in the Encinal, is likewise absent from the Fir Forest. The deciduous Quercus submollis and the widely distributed Populus tremuloides are the commonest of the subordinate trees, the latter often becoming dominant over areas of an acre or more in extent, where it ultimately gives way to conifers.

The floor of the Fir Forest is much more heavily and continuously shaded than that of the densest stands of pine, a circumstance which is of great importance in determining the nature of the forest reproduction and also in conditioning the character of the shrubby and herbaceous vegetation. The dense shade, the heavy litter, and the high humus content of the soil tend to preserve its moisture throughout the arid fore-summer (see p. 61), so that the seedling trees and other plants of these situations are very far removed from the desiccating influences which are operative in the open Pine Forest. The Fir Forest near the summits of ridges is somewhat more open than that which is found on middle and lower slopes, and this difference is accompanied by a dissimilarity in the herbaceous flora of upper and lower slopes. On the latter may frequently be found communities of plants which differ little in their specific make-up from the communities which occupy floodplains, although they are much less dense.

The heaviest stands of Abies and Pseudotsuga, like most heavy coniferous forests, are relatively poor in both shrubs and herbaceous plants. A few of the shrubs common to the water-courses are to be found also in the Fir Forest, such as Jamesia americana, Symphoricarpos oreo- 
philus, Ribes pinetorum, and Rubus neomexicanus. The trifoliate maple, Acer glabrum, also occurs locally on the north slopes of Mount Lemmon. The poverty in the stand of herbaceous species on the floor of the Fir Forest is contrasted with the large number of species to be found, which is probably not so great, however, as the number characteristic of the open Pine Forest. Most common are: Bromus richardsonii, Cystopteris fragilis, Geranium caspitosum, Frasera speciosa, Thalictrum fendleri var. wrightii, Galium asperrimum, Smilacina sessilifolia, Osmorhiza nuda, Disporum trachycarpum, Viola canadensis var. rydbergii, Oxalis metcalfi, Fragaria ovalis, Trifolium rusbyi, and Draba helleriana. On Abies the parasitic Phoradendron bolleanum is not infrequent.

The banks of constant and intermittent streams and the narrow flood-plains of the Fir Forest region form a series of habitats with closely similar physical conditions and with nearly identical vegetation. In them are to be found a greater abundance and variety of trees and shrubs than occur in topographically analogous habitats at lower elevations. Abies, Pscudotsuga, Pinus strobiformis, and even Pinus arizonica occur in this habitat. Its commonest woody plants, however, are those which do not occur in other situations, as Alnus acuminata, Acer interior, Acer brachypterum, Salix scouleriana, Salix exigua, Salix taxifolia, Sorbus dumosa, Cornus stolonifera var. riparia, Jamesia americana, Sambucus vestita, Symphoricarpos oreophilus, Rubus arizonicus, Ribes pinetorum, and Salix sp.

In this same series of habitats, which are the most elevated of the moist habitats of the mountain, is the most dense stand of herbaceous vegetation that occurs on the Santa Catalinas. This vegetation is rich in species and varies in its make-up from place to place according to the amount of soil moisture present and according to the openness or shade. In the following list are given the characteristic plants of these situations. The two species of Mimulus are the only plants invariably confined to the immediate proximity of water. Such plants as Dugaldia and Agrimonia, on the other hand, are found only in the unshaded floodplains. A comparison of this list with that just given for the floor of the Fir Forest will show that the latter habitat has few distinctive species.

Characteristic Herbaceous Plants of Flood-Plains, Stream Banks, and Lower Slopes in the Fir Forest.

* Aconitum columbianum.

** Actra viridiflora.

*** Agrimonia brittoniana var. occidentalis.

** Agrostis scabra var. subrepens.

* Aralia humilis.

** Aspidium filix-mas.

*** Bromus richardsonii.

*** Carex sp.

** Carex sp.

** Cerastium sericeum.

* Delphinium scopulorum.

** Disporum trachycarpum.

** Draba helleriana.

*** Dugaldia hoopesii.

** Epilobium novomexicanum.

** Equisetum robustum.

*** Frasera speciosa.

*** Galium asperrimum.

* Gentiana microcalyx.

*** Geranium coespitosum.

** Glyceria nervata.

** Gyrostachys sp.

** Heracleum lanatum. 


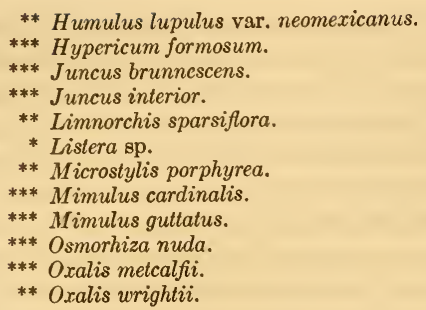

* Polygonum douglasii.

** Pyrola chlorantha.

** Pyrola secunda.

** Rubus arizonicus.

** Rudbeckia laciniata.

*** Scrophularia sp.

*** Smilacina amplexicaulis.

** Smilacina sessilifolia.

** Solanum fendleri.

*** Thalictrum fendleri var. wrightii.

*** Viola canadensis var. rydbergii.

*** Viola nephrophylla.

\section{FLORA OF THE SANTA CATALINA MOUNTAINS.}

The wide range of physical conditions embraced within the area of the Santa Catalina Mountains gives them a relatively large flora, which has been estimated by Professor J. J. Thornber to be about 1,500 species. Although the exploitation of this flora is not completed it is nevertheless sufficiently well advanced to show that elements are present which are common to each of many diverse regions lying north, south, east, and west.

The desert at the foot of the mountains stands in unbroken connection with the deserts of Sonora and Sinaloa. The Encinal and Forest regions, on the other hand, are isolated from other areas possessing the same physical conditions. Areas of Encinal are numerous and near, both on the low desert mountains and on the elevated plains of southern Arizona; while bodies of forest are to be found only at greater distances and more remotely separated from each other. The floristic history of the Encinal and Forest regions of the Santa Catalinas is quite as intimately bound up with the controlling influences of climatic conditions as is the present limitation of the vegetation. In fact the floras of the two isolated regions are a resultant between the physical conditions which they have presented in the remote and recent past and the operation of natural agencies of dispersal.

\section{PHYTOGEOGRAPHIC RELATIONSHIPS OF THE FLORA.}

It would not be within the scope of this paper to enter upon a detailed discussion of the floristic relationships of the isolated mountain areas of Encinal and Forest in southern Arizona, even if all the evidence bearing on such a discussion were now in hand. It will be instructive, however, to point out very briefly some of the principal floristic relationships of the Santa Catalinas in order to demonstrate the extensive and diversified area over which members of its flora may be found.

THE DESERT FLORA.

The flora which occupies the bajadas of the Santa Cruz valley and the lower slopes of the Santa Catalina Mountains derives many species from each of two Mexican desert regions, the one lying at low elevations 
between the Sierra Madre Occidental and the Gulf of California, in the States of Sonora and Sinaloa, the other lying at higher elevations in the States of Chihuahua and Zacatecas. There are strong diversities of flora between these two Mexican deserts, although they do not fail to have many species in common. The Sierra Madre forms an effective barrier between them in Mexico, but north of the International Boundary the continental divide is formed by scattered mountain ranges and broad valleys rather than by a continuous elevated range, and these valleys, lying between 4,000 and 5,000 feet, have permitted the intermingling of species from the two desert floras, at the same time that they have constituted a barrier to many species presumably unable to withstand the winter temperature conditions of the elevated valleys. The deserts which border the lower course of the Colorado River in Arizona and California, the Mojave Desert, and other desert regions in southern California and Nevada lying below 4,000 feet, possess a very small number of distinctive species as contrasted with the two Mexican desert regions, and have contributed almost no species to the flora of the Santa Cruz valley, although many species of wide Mexican occurrence are represented in both localities. The deserts of the Great Basin have likewise contributed no distinctive elements to the flora of the Santa Cruz Valley and the Desert region of the Santa Catalinas.

Among the many species characteristic of the Arizona-Sonora Desert which do not cross the continental divide are: Carnegiea gigantea, Parkinsonia microphylla, Encelia farinosa, Olneya tesota, Hyptis emoryi, Franseria deltoidea, Simmondsia californica, Jatropha cardiophylla, and Crossosoma bigelovii. Among the desert species which are common to the Arizona-Sonora region and to the Texas-Chihuahua desert are: Fouquieria splendens, Koberlinia spinosa, Chilopsis saligna, Momisia pallida, Coldenia canescens, Opuntia leptocaulis, Ephedra trifurca, Hilaria mutica, and Baileya multiradiata.

It would be possible to place perhaps 90 per cent of the desert flora of southern Arizona in one or the other of the categories just mentioned. There are a few local and endemic species, but very few species exhibit ranges extending chiefly to the west, north, or east. Among the two Mexican elements many species range far south of Mexico, as witness the following, which are found in the deserts of Chile: Calandrinia menziesii, Bowlesia lobata, Daucus pusillus, Parietaria debilis, and Hydrocotyle ranunculoides. A large number of the genera found in the Desert flora also possess representatives in the deserts of Argentine and Chile, as: Covillea, Franseria, Encelia, Actinella, Krameria, Gutierrezia, Viguiera, Chorizanthe, Coldenia, Perezia, Menodora, Nama, Amsinckia and many others. Other genera found in the Santa Cruz Valley have many representatives in tropical South America or in the West Indies, as Hyptis, Dodonca, Erythrina, and Gymnolomia, or have a world-wide representation, as Tragia and Stemodia. 
Enough has been said to show that both the specific and generic relationships of the Desert flora are with the desert regions of Mexico, the deserts of Argentine and Chile, and even with the moist tropical regions of South America. The plants which dominate the Desert landscape in southern Arizona are members of genera, or even of species, which characterize a much greater area to the south than to the north, and they are in the main members of genera which reach their maximum development in number of species and in abundance of individuals in similar desert regions. The plants of the Desert which are of tropical relationship are usually the sole and northernmost representatives of families or genera which are much more richly represented, both in types and in individuals, in the tropical zone. These plants are often so infrequent and inconspicuous as scarcely to interest the student of vegetation, except for the fact that their seasonal behavior and habitat relations are such as to give them the most moist conditions which the Desert affords. Among them may be mentioned: Passiflora, Stemodia, Maurandia, and Rivina.

The few members of genera of northern dominance, such as Populus and Salix, or Anemone and Delphinium, are either to be sought in the vicinity of streams and ponds, as is the case with the former two, or are to be found in activity only in the late winter and early spring, as is true of the latter two. The still fewer species of transcontinental range are almost solely palustrine plants, as Cephalanthus occidentalis, Scirpus americanus, Cyperus diandrus, and others, and are to be found only in palustrine situations in Arizona.

\section{THE ENCINAL FLORA.}

The type of vegetation which is designated as Encinal in this paper is found throughout southern Arizona and New Mexico at elevations of 5,000 to 7,000 feet. It is pre-eminently a community of evergreen oaks and nut pines, with many sclerophyllous shrubs. With many floristic modifications this type of Encinal extends into western Texas, Colorado, and inner California, usually as a belt connecting the treeless plains or desert with the forested mountain tops. Encinal similar to that of southern Arizona is found throughout the mountainous portions of Sonora, Chihuahua, Sinaloa, and Zacatecas, and with many modifications it extends still further south.

The dominant species of the Encinal of the Santa Catalinas range far to the south along both sides of the Sierra Madre, whereas but few of them range further north than the southern edge of the Mogollon Plateau in central Arizona, and some of them not even so far as that. The 14 commonest woody or semi-succulent perennials in the Encinal of the Santa Catalinas are all plants of extended Sonoran and Chihuahuan distribution; all of them occur in southern New Mexico and eight of them in western Texas. Only one of the plants reaches Cali- 
fornia and only one of them has been reported from Colorado. These plants are:

\begin{tabular}{l|l} 
Quercus oblongifolia. & Arctostaphylos pungens, Cal. \\
Quercus arizonica. & Garrya wrightii, Tex. \\
Quercus emoryi, Tex. & Dasylirion wheeleri, Tex. \\
Vauquelinia californica. & Agave palmeri. \\
Juniperus pachyphlœa, Tex. & Nolina microcarpa.
\end{tabular}

Pinus cembroides, Tex. Mimosa biuncifera, Tex. Chrysoma laricifolia, Tex. Eriogonum wrightii, Col., Tex.

The Encinal likewise comprises a number of plants which reach their maximum occurrence on the Great Plains or else possess areas of distribution which are chiefly to the northeast of Arizona. Among these are Bouteloua obligostachya, Bouteloua hirsuta, Bouteloua curtipendula, Polygala alba, Artemisia ludoviciana, Artemisia dracunculoides, and Stephanomeria runcinata.

The elements which are common to the flora of California are few, as is true of the Desert, and are almost solely comprised in the following: Zauschneria californica, Amorpha californica, Bouvardia triphylla, and Brickellia californica, not to add Arctostaphylos pungens, which has its maximum extension southward into Mexico. The Encinal contains a number of forms which have been but recently segregated from wellknown species, among them Rhus racemulosa, Rhamnus ursina, and Prunus virens. So little is known of the ranges of these species that it is impossible to state in how far they may represent contributions from distant floras or to what extent they represent forms that have been differentiated in the Arizona-Sonora region.

The only northern element in the Encinal flora seems to be that which has been mentioned as occurring also in the Great Plains, while the mountainous regions of Colorado and Utah have contributed even fewer species than has the Californian region.

THE FOREST FLORA.

The Forest region of the Santa Catalinas possesses strong floristic affinities both with the Mexican cordillera and with the Rocky Mountains of Colorado and their southern extension in New Mexico. The majority of the plants which take a conspicuous place in the vegetation of the Forest are members of northern genera. Many of these members are identical with Rocky Mountain species, while many others have their chief range in the mountains of northern Mexico. There are also representatives of a few genera which are distinctively Mexican, a few species of northwestern relationship, and a few apparently of restricted range in the desert mountains of Arizona and New Mexico.

As examples of the large Rocky Mountain contingent in the Forest flora may be mentioned:

Abies concolor.

Pseudotsuga mucronata.

Disporum trachycarpum.

Salix scouleriana.

Populus tremuloides.
Acer glabrum.

Jamesia americana.

Symphoricarpos oreophilus.

Frasera speciosa.

Dugaldia hoopesii.
Erigeron macranthus.

Heuchera rubescens.

Brickellia grandiflora.

Gilia thurberi.

Achillea lanulosa. 
Some of the members of this group are of wide distribution in the north, as Populus tremuloides, Achillea lanulosa, and Disporum trachycarpum. In the northern mountain contingent are also a few species which range eastward to the Atlantic coast, a few which are found at least as far south as Maryland (Heracleum lanatum, Rudbeckia lacinitata, A pocynum androscmifolium, Vicia americana, and Asplenium trichomanes), not to mention Achillea lanulosa, which scarcely deserves separation from the cosmopolitan Achillea millefolium.

The relationship with northern California and the northwestern states is weakly expressed in the occurrence of Salix lasiolepis and Prunus emarginata. Genera characteristic of the sub-arctic regions are sparingly represented at higher elevations by species of Primula, Saxifraga, and Androsace.

Some of the most conspicuous components of the vegetation belong to northern genera, but to species which are characteristic of the Mexican cordillera, as Pinus arizonica, Pinus strobiformis, Alnus acuminata, Salix bonplandiana, Quercus hypoleuca, and Quercus reticulata. Such genera of herbaceous plants as Solidago, Eupatorium, Erigeron, Pentstemon, Mimulus, Potentilla, Gilia, and Gentiana-all of which are richly developed in the Rocky Mountains-are chiefly represented in the Santa Catalinas by species not found in Colorado nor Wyoming. The extent to which these species are characteristic of the Arizona-New Mexico region or are components of the flora of the higher Mexican mountains is only partially known.

The relationship of the Forest flora to that of the extended mountain regions to the south is still further strengthened by the occurrence of members of genera which are not found in the Rocky Mountains of Colorado and northern New Mexico, as Arbutus, Calliandra, Microstylis, Drymaria, Cologania, Stevia, and Tagetes.

To summarize for the mountain as a whole, it may be said that the floristic relationships of the Desert and Encinal regions are almost wholly with the Mexican deserts and foothills to the south, while those of the Forest region are divided between the Mexican Cordillera and the Rocky Mountains. The Mexican group is the more conspicuous in the make-up of the vegetation, while the Rocky Mountain contingent is apparently preponderant in number of species.

It will be impossible to summarize the floristic relationships of the Santa Catalinas in a thorough manner until very much more is known of their own flora and also of the floras of the many adjacent mountain ranges and desert valleys, both in the United States and in Mexico. For the explanation of these relationships a closer acquaintance is needed with the actual mechanisms of transport which are effective in the dispersal of the seeds of desert and mountain plants. A fuller knowledge is also required of the fluctuations of climate within recent geological time, and of the consequent downward and upward movements of the Encinal and Forest belts of all the southwestern mountains. Such movements would alter- 
nately establish and break the connections between the vegetations of the various mountain ranges and elevated plains, thereby permitting the dispersal and subsequent isolation of species which might find no means of movement across the desert valleys under existing conditions.

\section{LIST OF CHARACTERISTIC SPECIES.}

The lack of a single taxonomic work covering the entire flora of the Santa Catalina Mountains makes it desirable to bring together here a list of the plant names which are used throughout this paper, together with some of the commoner synonyms. The list comprises only those plants which are common and characteristic components of the vegetation of some particular region or habitat of the mountain. The writer wishes to express here his very great indebtedness to Professor J. J. Thornber, of the University of Arizona, for determining numerous sets of plants from the Santa Catalinas and for verifying the following list.

\section{Polypodiaces:}

Aspidium filix-mas (L.) Sw.

$=$ Dryopteris filix-mas (L.) Schott.

Asplenium trichomanes $\mathrm{L}$.

Cheilanthes fendleri Hook.

Cheilanthes lindheimeri Hook.

Cheilanthes wrightii Hook.

Cystopteris fragilis (L.) Bernh. $=$ Filix fragilis (L.) Underw.

Gymnopteris hispida (Mett.) Underw. = Gymnogramme hispida Mett.

Notholana ferruginea (Desv.) Hook.

Notholona hookeri D. C. Eaton.

Notholana sinuata (Sw.) Kaulf.

Pelloa wrightiana Hook.

Pteris aquilina var. pubescens Underw.

Woodsia mexicana Fee.

Equisetacem:

Equisetum robustum A. Br.

Selaginellacex:

Selaginella rupincola Underw.

Selaginella sp.

Pinaces:

Abies arizonica Merriam.

Abies concolor Lindl. \& Gord.

Cupressus arizonica Greene.

Juniperus pachyphloa Torr.

Pinus arizonica Engelm.

Pinus cembroides Zucc.

Pinus chihuahuana Engelm.

Pinus strobiformis Engelm.

Pseudotsuga mucronata (Raf.) Sudw.

= Pseudotsuga taxifolia (Lam.) Britton.

Gnetacese:

Ephedra trifurca Torr.

Graminex:

Agrostis scabra var. subrepens Hitchek.

Andropogon saccharoides Sw.

=Amphilophis saccharoides (Sw.) Nash.

Andropogon scoparium Michx.

Aristida americana var. bromides (H. B. K.) Scribn. \& Merr.

Aristida divergens Vasey.

Aristida scheidiana Trin. \& Rupr.

Bouteloua aristidoides (Kunth) Griseb.

Bouteloua curtipendula (Michx.) Torr.
Gramines-Continued:

Bouteloua hirsuta Lag.

Bouteloua oligostachya (Nutt.) Torr.

Bouteloua polystachya (Benth.) Torr.

Bouteloua rothrockii Vasey.

Bromus richardsonii Link.

Diplachne dubia (Nees) Benth.

Eragrostis lugens Nees.

Eragrostis neomexicana Vasey.

Eragrostis pilosa (L.) Beauv.

Heteropogon contortus (L.) Beauv.

Hilaria cenchroides H. K. B.

Hilaria mutica (Buckl.) Benth.

Kuleria cristata (L.) Pers.

Leptochloa mucronata (Michx.) Kunth.

Muhlenbergia affinis Trin.

Muhlenbergia dumosa Scribn.

Muhlenbergia distichophylla (Presl) Munro.

Muhlenbergia gracillima Torr.

Muhlenbergia porteri Scribn.

Muhlenbergia vaseyana Scribn.

Muhlenbergia virescens (H. B. K.) Trin.

Muhlenbergia sp.

Panicularia nervata (Willd.) Kze.

Panicum bulbosum H. B. K.

Panicum bulbosum var. minor Vasey.

Panicum hallii Vasey.

Panicum hirticaulum Presl.

Papphorum wrightii Wats.

Poa fendleriana (Steud.) Vasey.

Sitanion elymoides Raf.

Sporobolus confusus (Fourn.) Vasey.

Stipa neomexicana (Thurb.) Scribn.

Cyperaces:

Carex sp.

Carex sp.

Cyperus fendlerianus Boeckl.

Cyperus inflexus Muhl.

Cyperus speciosus Vahl.

Eleocharis montana (H. B. K.) R. \& S.

Fimbristylis sp.

Hemicarpha micrantha (Vahl) Britt.

Stenophyllus capillaris (L.) Britt.

Commelinacee:

Commelina dianthifolia DC.

Tradescantia scopulorum Rose.

Tradescantia pinetorum Greene. 


\section{List of Characteristic Species-Continued.}

JUNCACEA:

Juncus arizonicus Wieg.

Juncus brunnescens Rydb.

Juncus bufonius L.

Juncus interior Wieg.

LILIACEA:

Anthericum torreyi Baker.

Brodicea capitata var. pauciflora Wats.

Calochortus nuttallii T. \& G.

Dasylirion wheeleri Wats.

Disporum trachycarpum (Wats.) B. \& H.

Nolina microcarpa Wats.

Smilacina amplexicaulis Nutt.

= Vagnera amplexicaulis (Nutt.) Morong.

Smilacina sessilifolia Nutt.

Yucca macrocarpa (Torr.) Coville.

Yucca schottii Engelm.

Amaryllidaces:

Agave palmeri Engelm.

Agave parryi Engelm.

Agave schottii Engelm.

IRIDACEA:

Sisyrinchium arizonicum Rothr. =Oreolirion arizonicum (Rothr.) Bicknell.

ORChIDACEA:

Gyrostachys sp.

Limnorchis sparsiflora (Wats.) Rydb.

Listera sp.

Microstylis corymbosa Wats. = Achroanthes corymbosa (Wats.) Greene.

Microstylis montana Rothr.

$=$ Achroanthes montana (Rothr.) Greene.

Microstylis porphyrea Ridley. $=$ Achroanthes porphyrea (Ridley) Greene.

SALICACEA:

Populus angustifolia James.

Populus tremuloides Michx.

Populus sp.

near to Populus wislizeni (Wats.) Sarg.

Salix bonplandiana $\mathrm{H}$. B. K.

Salix exigua Nutt.

Salix scouleriana Barr.

Salix taxifolia H. B. K.

Salix wrightii Anders.

Salix sp.

JUALANDACEAE:

Jugland major (Torr.) Hell.

Betulaces:

Alnus acuminata $\mathrm{H}$. B. K. = Alnus oblongifolia Torr.

Fagacée:

Quercus arizonica Engelm.

Quercus emoryi Torr.

Quercus hypoleuca Engelm.

Quercus oblongifolia Torr.

Quercus reticulata Humb. \& Bonpl.

Quercus submollis Rydb.

ULMACEA:

Momisia pallida (Torr.) Planch. = Celtis pallida Torr.

Celtis reticulata Torr. $=$ Celtis occidentalis var. reticulata (Torr.) Sarg.

MoRACEA:

Humulus lupulus var. neomexicanus Nels. \& Cockrl.

Morus celtidifolia H. B. K.
SANTAlaceæ:

Comandra pallida A. DC.

LORANTHACEA:

Arceuthobium divaricatum Engelm.

= Razoumofskya divaricata (Engelm.) Kze.

Arceuthobium robustum Engelm.

= Razoumofskya robusta (Engelm.) Kze.

Phoradendron bolleanum Eichl.

Phoradendron californicum Nutt.

Phoradendron flavescens var. villosum

Engelm.

Phoradendron juniperinum Engelm.

Polygonacese:

Chorizanthe brevicornu Torr.

Eriogonum abertianum Torr.

Eriogonum pharnaceoides Torr.

Eriogonum wrightii Torr.

Polygonum douglasii Greene.

Rumex hymenosepalus Torr.

Chenopodiaces:

Chenopodium fremontii Wats.

Amarantacese:

Amaranthus palmeri Wats.

Cladothrix lanuginosa Nutt.

Frolichia floridana (Nutt.) Moq.

Gomphrena cospitosa Torr.

Gomphrena nitida Rothr.

Nyctaginacea:

Allionia gracillima Standley.

Boerhaavia pterocarpa Wats.

Boerhaavia watsoni Standley.

Wedelia incarnata (L.) Kze.

Portulacaces:

Calandrinia menziesii (Hook.) T. \& G.

Calyptridium monandrum Nutt.

Montia perfoliata (Donn.) Howell.

Talinum patens var. sarmentosum (Engelm.) Gray.

Caryophyllaces:

Arenaria confusa Rydb.

Cerastium sericeum Wats.

Cerastium texanum Britt.

Drymaria sperguloides Gray.

Drymaria tenella Gray.

Silene laciniata var. greggii (Gray) Wats.

RANUNCULACEE:

Aconitum columbianum Nutt.

Actca viridiflora Greene.

Aquilegia chrysantha Gray.

Clematis ligusticifolia Nutt.

Myosurus cupulatus Wats.

Thalictrum fendleri var. wrightii Gray.

BERBERIDACEAE:

Berberis wilcoxii Kearney.

Papaveracere:

Eschscholtzia mexicana Greene.

Platystemon californicus Benth.

Crucifere:

Draba helleriana Greene.

Draba spectabilis Grcene.

Lepidium lasiocarpum Nutt.

Lesquerella gordoni (Gray) Wats.

Thelypodium linearifolium Gray.

Crassuraces:

Sedum stelliforme Wats.

Tillae erecta Hook. \& Arn. 
$L$ ist of Characteristic Species-Continued.

SAxifragace无:

Fendlera rupicola Engelm. \& Gray.

Heuchera rubescens Torr.

Heuchera sanguinea Engelm.

Jamesia americana T. \& G.

$=$ Edwinia americana (T. \& G.) Hell.

Ribes pinetorum Greene.

Saxifraga eriophora Wats.

$=$ Micranthes eriophora (Wats.) Small.

Platanaces:

Platanus wrightii Wats.

Crossosomatacea:

Crossosoma bigelovii Wats.

ROSACEA:

Agrimonia brittoniana var. occidentalis Bicknell.

Cowania stansburiana Torr.

Fragaria ovalis (Lehm.) Rydb.

Holodiscus dumosus (Nutt.) Hell.

Potentilla thurberi Gray.

Potentilla subviscosa Greene.

Prunus virens (Woot. \& Stand.)

$=$ Padus virens Woot. \& Stand.

Rosa fendleri Crepin.

Rubus arizonicus Greene.

Rubus neomexicanus Gray.

Rubus oligosperma Thornb.

Sorbus dumosa Greene.

Vauquelinia californica (Torr.) Sarg.

LEguminose:

Acacia greggii Gray.

Acacia paucispina Wooton.

Acacia suffrutescens Rose.

Amorpha californica Nutt.

Anisolotus argensis Coville.

Anisolotus puberulus (Benth.) Woot. \& Stand. = Hosackia puberula Benth.

Anisolotus trispermus(Greene) Woot.\& Stand. =Lotus trispermus Greene.

Cassia covesii Gray.

Cassia leptadenia Greenm.

=Chamacrista leptadenia (Greenm.) Cockrl.

Cassia leptocarpa Benth.

Calliandra eriophylla Benth.

Calliandra reticulata Gray.

Calliandra humilis Benth.

Cologania longifolia Gray.

Crotolaria lupulina Raf.

Dalea albiflora Gray.

= Parosela albiflora (Gray) Vail.

Dalea parryi T. \& G.

= Parosela parryi (T. \& G.) Hell.

Dalea polyoonoides Gray.

= Parosela polygonoides (Gray) Hell.

Dalea wislizeni Gray.

$=$ Parosela wislizeni (Gray) Vail.

Desmodium arizonicum Wats. $=$ Meibomia arizonica (Wats.) Vail.

Desmodium bigelovii Gray. = Meibomia bigelovii (Gray) Kze.

Desmodium grahami Gray. = Meibomia grahami (Gray) Kze.

Desmodium psilocarpum Gray. = Meibomia psilocarpa (Gray) Kze.

Erythrina flabelliformis Kearney.

Eysenhardtia orthocarpa (Gray) Wats.

Indigofera sphorocarpa Gray.
LEGUMINOSA-Continued:

Lathyrus graminifolius (Wats.) White.

Lupinus sp.

near to Lupinus palmeri Wats.

Mimosa biuncifera Benth.

Nissolia schottii (Torr.) Gray.

Parkinsonia microphylla Torr.

Parkinsonia torreyana Wats.

= Cercidium torreyanum (Wats.) Sarg.

Phaseolus retusus Benth.

Phaseolus wrightii Gray.

Prosopis velutina Wooton.

Robinia neomexicana Gray.

Trifolium pinetorum Greene.

Vicia americana Muhl.

Vicia melilotoides Woot. \& Stand.

Geraniaces:

Geranium caspitosum James.

OXALIDACEA:

Oxalis albicans H. B. K. =Ionoxalis albicans (H. B. K.) Small.

Oxalis metcalfi (Small).

$=$ Ionoxalis metcalfi $i$ Small.

LINACEA:

Linum lewisii Pursh.

Linum neomexicanum Greene.

ZYGOPHYLLACEDS:

Covillea tridentata (DC.) Vail. $=$ Larrea tridentata (DC.) Coville.

Rutaces:

Ptelea cognata Greene.

Malpighiacez:

Janusia gracilis Gray.

Polygalace.e:

Krameria glandulosa Rose \& Painter.

Polygala alba Nutt.

EUPHORBIACEA:

Croton texensis (Klotsch) Muell. Arg.

Euphorbia crenulata Engelm.

Euphorbia florida Engelm.

Euphorbia heterophylla L.

Euphorbia melanadenia Torr.

Euphorbia pediculifera Engelm.

Jatropha angustidens Muell. Arg.

Jatropha cardiophylla (Torr.) Muel. Arg.

Manihot carthaginensis Muel. Arg.

Callitrichacese:

Callitriche sp.

BuXACEA:

Simmondsia californica Nutt.

Anacardices:

Rhus aromatica var. mollis (Gray) Ashe.

Rhus elegantula Greene.

Rhus rydbergii Small.

=Toxicodendron rydbergii (Small) Greene.

Rhus trilobata Nutt.

ACERACEA:

Acer brachypterum Woot. \& Stand.

Acer glabrum Torr.

Acer interior Britt.

SAPINDACEA:

Dodonaca viscosa var. angustifolia. (L. f.) Benth.

Sapindus drummondii Hook. \& Arn.

RhamNaCeA:

Ceanothus fendleri Gray.

Ceanothus fendleri var. venosus Trel. Rhamnus crocea var. pilosa Trel.

Rhamnus ursina Greene. 


\section{List of Characteristic Species-Continued.}

Rhamaces-Continued:

Zizyphus lycioides var. canescens Gray. $=$ Condalia lycioides (Gray) Weberbaur.

Vitacex:

Parthenocissus dumetorum var. laciniata Rehder.

= Parthenocissus quinquefolia var. laciniata Planch.

Vitis arizonica Engelm.

Malvaceat:

Abutilon incanum (Link) Sweet.

Ingenhousia triloba DC.

= Thurberia thespesioides Gray.

Malvastrum sp.

Sphaeralcea pedata Torr.

STERCULIACEE:

Ayenia microphylla Gray.

HXPERICACEE:

Hypericum formosum $\mathrm{H}$. B. K.

Fovquieraces:

Fouquieria splendens Engelm.

VIOLACEx:

Viola canadensis var. rydbergii (Greene) House.

Viola nephrophylla Greene.

LOASACEA:

Mentzelia albicaulis Dougl.

CaCtaces:

Carnegiea gigantea (Engelm.) Britt. \& Rose. $=$ Cereus giganteus Engelm.

Echinocactus wislizeni Engelm.

Echinocereus fendleri (Engelm.) Rumpl.

Echinocereus polyacanthus Engelm.

Mamillaria arizonica Engelm.

Mamillaria grahami Engelm.

Opuntia bigelovii Engelm. \& Bigel.

Opuntia blakeana Rose.

Opuntia engelmanni Salm Dyck.

Opuntia fulgida Engelm.

Opuntia lovvis Coult.

Opuntia leptocaulis DC.

Opuntia mamillata Schott.

Opuntia santa-rita (Griff. \& Hare) Rose.

Opuntia spinosior (Engelm. \& Bigel.) Toumey.

Opuntia toumeyi Rose.

Opuntia versicolor Engelm.

Opuntia sp.

Opuntia sp.

ONAGRACEE:

Epilobium novomexicanum Hausk.

Gaura suffulta Engelm.

Isnardia palustris L. $=$ Ludwigia palustris (L.) Ell.

Enothera hookeri $\mathrm{T}$. \& $\mathrm{G}$. = Onagra hookeri (T. \& G.) Small.

Enothera mexicana Spach.

Zauschneria californica Presl.

Araliaces:

Aralia humilis Cav.

UMBELLIFERE:

Daucus pusillus Michx.

Heracleum lanatum Michx.

Hydrocotyle ranunculoides L. $\mathrm{f}$.

Osmorhiza nuda Torr.

$=$ Washingtonia obtusa C. \& R.

Pseudocymopterus montanus var. purpureus C. \& R.
UMBELLIFERE-Continued:

Pseudocymopterus montanus var. tenuifolius (Gray) C. \& R.

Cornacea:

Cornus stolonifera var. riparia (Rydb.)

Garrya wrightii Torr.

Ericaces:

Arbutus arizonica (Gray) Sarg.

Arctostaphylos pringlei Parry.

Arctostaphylos pungens H. B. K.

Hypopitys sanguinea Hell.

Pterospora andromedea Nutt.

Pyrola chlorantha Sw.

Pyrola secunda L.

Primulaces:

Androsace diffusa Small.

Androsace arizonica Gray.

Primula rusbyi Greene.

Oleacea:

Fraxinus attenuata Jones.

Fraxinus toumeyi Britt.

Menodora scabra Gray.

Apocynaces:

A pocynum androsamifolium $\mathrm{L}$.

A pocynum scopulorum Greene.

Haplophyton cimicidium A. DC.

AsCle piadacee:

Asclepias linaria Cav.

Asclepias tuberosa L.

Gomphocarpus hypoleucus Gray.

Convolvulacem:

Evolvulus arizonicus Gray.

I pomaea capillacea Don.

Ipomcea coccinea var. hederifolia Gray.

I pomce muricata Cav.

POLfmontace

Gilia floccosa Gray.

Gilia multiflora Nutt.

Gilia thurberi Gray.

Linanthus aureus (Nutt.) Greene.

HYDROPHYLLACEA:

Ellisia torreyi Gray.

Emmenanthe penduloflora Benth.

Nama hispida Gray.

Phacelia distans Benth.

BorraginaCeA:

Amsinckia tessellata Gray.

Coldenia canescens DC.

Cryptanthe intermedia (Gray) Greene.

Cryptanthe pterocarpa (Torr.) Greene.

Eremocarya micrantha (Torr.) Greene.

Lithospermum multiflorum Torr.

Onosmodium thurberi Gray.

Pectocarya linearis DC.

VERBENACEA:

Lippia wrightii Gray.

Verbena ciliata Benth.

Verbena wrightii Gray.

LABIAT

Agastache pallidiflora (Hell.) Rydb.

Hedeoma hyssopifolia Gray.

Hyptis emoryi Torr.

Monarda pectinata Nutt.

Monarda scabra Beck.

Salvia arizonica Gray.

Stachys coccinea Jacq.

Trischostema arizonicum Gray. 
List of Characteristic Species-Continued.

Solanaceza:

Lycium berlandieri Dunal.

Lycium fremontii Gray.

Lycium partiflorum Gray.

Nicotiana trigonophylla Dunal.

Solanum fendleri Gray.

SCROPHULARIACEE:

Castilleja gloriosa Britt.

Castilleja integra Gray.

Cordylanthus wrightii Gray.

Linaria canadensis L.

Maurandia antirrhinifolia (Poir.) Willd.

Mecardonia peduncularis (Benth.) Greene.

Mimitanthe pilosa (Benth.) Greene. =Mimulus pilosus Wats.

Mimulus cardinalis Dougl.

Mimulus outtatus (L.) DC.

Mimulus langsdorfi Sims.

Orthocarpus purpurascens Benth.

Pentstemon barbatus (Cav.) Nutt.

Pentstemon spectabilis Thurber.

Pentstemon torreyi Benth.

Pentstemon wrightii Hook.

Scrophularia sp.

Stemodia durantifolia (L.) Sw.

Bienoniace.e:

Chilopsis linearis (Cav.) Sweet. =Chilopsis saligna Don.

Stenolobium incisum Standley.

Acantraces:

Anisacanthus thurberi (Torr.) Gray. Carlowrightia arizonica Gray.

Plantaginaces:

Plantago fastigiata Morris.

Plantago ignota Morris.

RUBIACEA:

Bouvardia triphylla Salisb.

Diodia teres Walt.

Galium asperrimum Gray.

Galium rothrockii Gray.

Galium wrightii Gray.

Houstonia wrightii Gray.

CAPRIFOLIACEA:

Sambucus mexicana Presl.

Sambucus vestita Woot. \& Stand.

Symphoricarpos oreophilus Gray.

VALERIANACEA:

Valeriana arizonica Gray.

Campanulaces:

Lobelia gruina Cav.

Specularia biflora (R. \& P.) Fisch. \& Mey.

Composites:

Achillea lanulosa Nutt.

Actinolepis lanosa Gray.

Antennaria marginata Greene.

Artemisia dracunculoides Pursh.

Artemisia ludoviciana Nutt.

Artemisia sp.

Artemisia sp.

Baccharis emoryi Gray.

Baccharis glutinosa Pers.

Baccharis pteronoides DC.

Baccharis sarothroides Gray.

Baccharis thesioides H. B. K.

Baria chrysostoma Fisch. \& Mey.

Bahia absinthifolia Benth.

Baileya multiradiata Harv. \& Gray.

Bebbia juncea (Benth.) Greene.
Composita-Continued:

Bidens sp.

Brickellia californica (T. \& G.) Gray.

= Coleosanthus californicus (T. \& G.) Kze.

Brickellia grandiflora Nutt.

=Coleosanthus grandiflorus (Hook.) Kze.

Carduus rothrockii (Gray) Greene.

Carduus sp.

Carpochote bigelovii Gray.

Chrysoma laricifolia (Gray) Greene.

$=$ A plopappus laricifolius Gray.

Crassina pumila (Gray) Kze.

$=$ Zinnia pumila Gray.

Dugaldia hoopesii (Gray) Rydb.

Encelia farinosa Gray.

Erigeron macranthus Nutt.

Erigeron neomexicanus Gray.

Erigeron wootoni Rydb.

Eriocarpum gracile (Nutt.) Greene.

= A plopappus gracilis (Nutt.) Grey.

Eupatorium arizonicum (Gray).

=Eupatorium occidentale var. arizonicum Gray.

Eupatorium pauperculum Gray.

Eupatorium rothrockii Gray.

Franseria cordifolia Gray.

Franseria deltoidea Torr.

= Gortneria deltoidea (Torr.) Kze.

Franseria tenuifolia Gray.

= Gartneria tenuifolia (Gray) Kze.

Franseria ambrosioides Cav.

Gnaphalium decurrens Ives.

Gnaphalium wriohtii Gray.

Guardiola platyphylla Gray.

Gymnolomia multiflora Rothr.

Gymnosperma corymbosa DC.

Helenium thurberi Gray.

Helianthella arizonica (Gray).

$=$ Helianthella quinquenervis var. arizonica Gray.

Hieracium discolor.

Hieracium lemmoni Gray.

Hymenoclea monogyra T. \& G.

Hymenopappus mexicanus Gray.

Hymenothrix wrightii Gray.

Isocoma hartwegi (Gray) Greene. $=$ Bigelovia hartwegi Gray.

Laphamia lemmoni Gray.

Laphamia sp. near to Laphamia halimifolia Gray.

Macharanthera tanacetifolia (H. B. K.) Nees.

Pectis papposa Gray.

Perityle coronopifolia Gray.

Picradenia biennis (Gray) Greene.

= Actinella biennis Gray.

Pinaropappus foliosus Hell.

Psilostrophe cooperi (Gray) Greene. $=$ Ridellia cooperi Gray.

$R$ Rdbeckia laciniata $L$.

Senecio neomexicanus Gray.

Solidago bigelovii Gray.

Solidago marshallii Rothr.

Solidago sparsiflora var. subcinerea Gray.

Stephanomeria runcinata Nutt.

Stevia sp.

Tagetes lemmoni Gray.

Trixis angustifolia var. latiuscula Gray.

Verbesina encelioides (Cav.) B. \& H.

=Ximenesia encelioides Cav. 


\section{CLIMATE OF THE SANTA CATALINA MOUNTAINS.}

The latitude of the Santa Catalina Mountains and their position in the midst of a continental desert give to their lower slopes the climate which is well known to characterize southern Arizona: a low unequally distributed rainfall, a short winter with frequent severe frost, and a long summer with high maximum temperatures and low atmospheric humidity. The longitudinal position of the Santa Catalinas, between the Pacific Coast and the southern Great Plains, gives to their climate also some of the characteristics of both these regions, notably in respect of the incidence of the rainfall seasons. Both the winter rains of the Pacific Coast and the summer rains which are prevalent on the Great Plains extend in attenuated form to Tucson and to the Santa Catalinas, giving them a short rainy season in July and August, often extending over into September, and a longer less pronounced rainy season from December to February or March.* Although the amount of rain in these seasons increases with altitude, the duration of the seasons themselves is essentially the same from Tucson to the summit of Mount Lemmon, and in fact throughout southeastern Arizona.

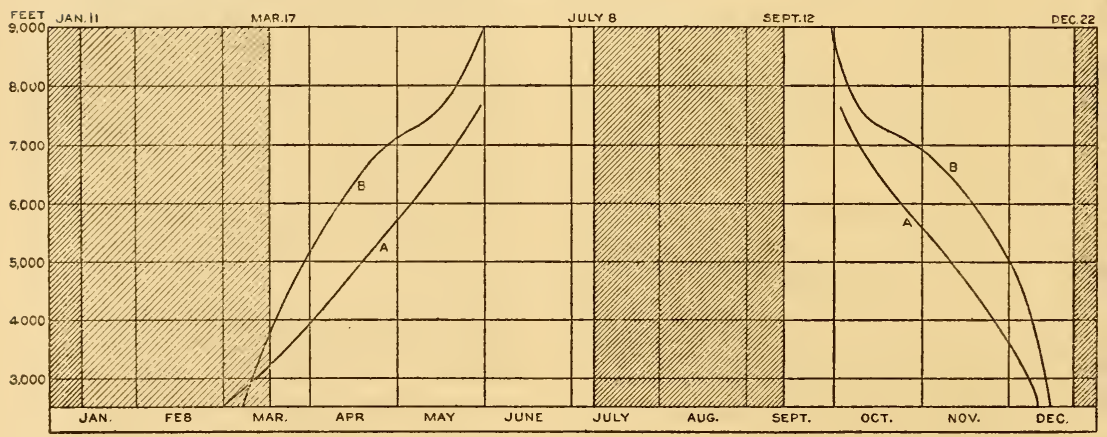

Fra. 2.- Schematic representation of rainfall seasons and length of frostless season at Tucson and in the Santa Catalina Mountains, showing averaged limiting dates of rainfall seasons for 8 years and averaged limits of the frostless season for 1909,1910 , and 1911 (A A), and for 1912, 1913, and 1914 (B B).

The long frostless season characteristic of Tucson and the foothills of the Santa Catalinas naturally decreases in length with altitude until at 8,000 feet it is only one half as long. The curves of decreasing length of frostless season and a diagrammatic representation of the incidence of the rainy seasons are shown in figure 2.

The gentle rains and occasional snowfall of the winter season serve to replenish the moisture of the soil at all altitudes, but on the desert

* See Shreve, Forrest. Rainfall as a Determinant of Soil Moisture. The Plant World, 17: $9-26,1914$. 
their effect is soon overcome by the desiccating conditions of March and April. The hot and rainless weeks which precede the mid-summer have been designated the "arid fore-summer." On the desert this is a season in which the temperature conditions are conducive to activity on the part of plants, while the soil moisture conditions are increasingly deterrent to it. As a result of these conflicting conditions activity may be observed in the trees which grow near a constant water supply, as Populus sp. (cottonwood) and Salix sp. (willows), trees which possess deep-seated root systems, as Prosopis velutina (mesquite), and plants which contain stores of water, as all species of cacti. The activity of Populus and Prosopis consists in both flowering and leafing-out, as well as in shoot growth; in the cacti it consists in flowering and in some species also in growth. Among all desert plants other than those indicated the arid fore-summer is a period of drought-rest.

With respect to the water relations of plants the arid fore-summer is the most trying season of the year, combining low soil moistures with atmospheric conditions that compel active transpiration. In all respects in which moisture conditions may be critical for the survival of individuals or the limitation of the distribution of species it is in the arid fore-summer that the critical intensity of these conditions must be sought.

The retardation of spring which accompanies increasing altitude results in a shortening of the arid fore-summer from a length of 15 weeks on the desert to 11 weeks at 6,000 feet and 6 weeks at 8,000 feet (see fig. 2). Not only does this trying season decrease in length with altitude, butits physical conditions becomeameliorated, as will be shown.

The "humid mid-summer" commences on July 8 and lasts until September 12, these being the average dates, for 8 years, of the first and last rains of 0.50 inch or more. In this season the moisture conditions of desert and mountain top are more nearly alike than at any other time. It is the season of greatest vegetative activity on the desert and in the forest also. On the desert it is the only season in which germinations take place among the perennials, and it is the chief season of growth among all perennial plants, including those that have been in leaf during the arid fore-summer. In the Encinal region the evergreen oaks renew their foliage at the advent of spring, but the great mass of vegetative activity awaits the humid mid-summer. In the Forest the pines also commence growth with the cessation of frost, but make their chief growth during July and August. The humid mid-summer is also the chief period of activity for the herbaceous perennials and small shrubs of the forested elevations. Heavy snowfall during mid-winter or the occurrence of exceptionally late winter rains may bring about growth among the herbaceous perennials of the forest during the arid fore-summer. In fact a few species, notably Frasera speciosa and Dugaldia hoopesii, commence growth before the last frosts of spring. 
At the higher altitudes the shortness of the growing season and the coldness of its nights are inimical to the activity of the herbaceous perennials. These circumstances make very difficult the introduction into the Forest region of plants which would seem calculated to flourish in a region of similar moisture conditions.

After the close of the humid mid-summer the desert is subjected to a variable period of 6 to 10 weeks of arid conditions, a season known as the "arid after-summer." Although the temperature, humidity, soil moisture, and evaporation may reach as extreme values in the arid after-summer as in the arid fore-summer, nevertheless the total duration of such extremes is not as great in the former season. A general cessation of vegetative activity occurs in September and October at the higher elevations and in October and November at the lower ones. On the desert it sometimes happens that occasional rains during the arid after-summer prolong the activity of the shrubs and even of the summer ephemerals to such a late date that they may be seen in flower side by side with root-perennials which are characteristic of the winter season.

\section{RAINFALL.}

The figures for the monthly average rainfall at Tucson, as determined from the 38-year record (1876 to 1913), show that the year falls naturrally into two humid and two arid seasons (see fig. 4). Without regard to the average dates upon which the heavy rains of the humid seasons commence or terminate, the humid winter may be seen to fall within December, January, February, and March, and the humid mid-summer within July, August, and September. Making this artificial division by months between the rainfall seasons, the percentages of the total annual precipitation which fall in the four seasons are as follows: humid winter 31.1 per cent, arid fore-summer 5.9 per cent, humid midsummer 50.6 per cent, arid after-summer 12.4 per cent. The two rainy seasons yield 81.7 per cent of the total annual rainfall, and the light rains of the two arid seasons (which form the remaining 18.3 per cent) are of very slight influence upon vegetation. The rains of November may bring forth some of the winter herbaceous perennials, without any effect on the large perennials other than the inducing of leaves on Fouquieria and Parkinsonia. The rains of the arid fore-summer are usually too light and too widely separated to bring into activity either the summer ephemerals or the perennial plants.

SEASONAL DISTRIBUTION OF RAINFALL.

On the Pacific Coast the monthly distribution of rainfall brings over 75 per cent of the annual total within the winter months. On passing eastward through Arizona this predominance of winter rain is gradually lost until it becomes less than 20 per cent of the annual total at the Rio Grande River in New Mexico. Conversely, the precipitation of 
the summer months is almost negligible on the Pacific Coast and gradually increases on passing eastward until it reaches 50 per cent at Tucson. Between Tucson and the Rio Grande it remains at about 50 per cent, but from the basin of the Rio Grande eastward the rainfall seasons of the Tucson region cease to be a natural division of the year (see table 1).

TABLE 1.-Percentages of summer rainfall and of winter rainfall to the annual rainfall for a series of stations stretching from the Pacific coast to the Rio Grande River, through southern Arizona.

\begin{tabular}{|c|c|c|c|}
\hline Station. & Winter. & Summer. & Total. \\
\hline Los Angeles, Cal.... . . . . . . . . . & 76.0 & .7 & 76.7 \\
\hline Riverside, Cal............. & 76.8 & 2.6 & 79.4 \\
\hline Indio, Cal. . . . . . . . . . & 73.3 & 12.0 & 85.3 \\
\hline Yuma, Ariz.......... & 59.0 & 20.3 & 79.3 \\
\hline Gila Bend, Ariz.... . & 47.5 & 35.5 & 83.0 \\
\hline Maricopa, Ariz.......... & 45.9 & 34.0 & 79.9 \\
\hline Casa Grande, Ariz......... & 43.7 & 37.6 & 81.3 \\
\hline Tucson, Ariz................. & 30.7 & 50.9 & 81.6 \\
\hline Benson, Ariz............ & 24.8 & 57.5 & 82.3 \\
\hline Bowie, Ariz.......... & 34.9 & 48.5 & 83.4 \\
\hline Lordsburg, N. Mex......... & 28.3 & 49.9 & 78.2 \\
\hline Deming, N. Mex........... & 22.9 & 54.8 & 77.7 \\
\hline Agricultural College, N. Mex. . & 17.5 & 56.8 & 74.3 \\
\hline
\end{tabular}

In figure 3 are given curves showing the percentages of the annual rainfall which are formed by summer rains and by winter rains for a chain of 13 stations stretching from Los Angeles to Mesilla Park, New Mexico, on the Rio Grande River.

TABLE 2.-The total annual rainfall, the summer rainfall, and the percentage of the latter to the former for very wet and very dry years at Tucson.

\begin{tabular}{|c|c|c|c|c|c|c|c|}
\hline \multirow{2}{*}{ Years. } & \multicolumn{3}{|c|}{$\begin{array}{l}\text { Eight wet years } \\
\text { (14 inches or over). }\end{array}$} & \multirow{2}{*}{ Years. } & \multicolumn{3}{|c|}{$\begin{array}{l}\text { Eleven dry years } \\
\text { ( } 9 \text { inches or less). }\end{array}$} \\
\hline & $\begin{array}{l}\text { An- } \\
\text { nual. }\end{array}$ & $\begin{array}{l}\text { Sum- } \\
\text { mer. }\end{array}$ & $\begin{array}{c}\text { Per- } \\
\text { centage. }\end{array}$ & & $\begin{array}{l}\text { An- } \\
\text { nual. }\end{array}$ & $\begin{array}{l}\text { Sum- } \\
\text { mer. }\end{array}$ & $\begin{array}{c}\text { Per- } \\
\text { centage. }\end{array}$ \\
\hline $1876 \ldots \ldots \ldots \ldots$ & 14.02 & 10.18 & 72.6 & $1880 \ldots \ldots \ldots \ldots$ & 6.61 & 4.79 & 72.5 \\
\hline $1878 \ldots \ldots \ldots \ldots$ & 16.66 & 10.51 & 63.1 & $1883 \ldots \ldots \ldots \ldots$ & 8.48 & 3.03 & 35.7 \\
\hline $1881 \ldots \ldots \ldots \ldots$ & 14.92 & 11.98 & 80.3 & $1885 \ldots \ldots \ldots \ldots$ & 5.26 & 2.88 & 54.8 \\
\hline $1882 \ldots \ldots \ldots \ldots$ & 15.59 & 9.27 & 59.5 & $1886 \ldots \ldots \ldots \ldots$ & 8.02 & 3.97 & 49.5 \\
\hline $1884 \ldots$ & 15.07 & 1.77 & 11.7 & $1891 \ldots \ldots \ldots \ldots$ & 7.78 & 3.44 & 44.2 \\
\hline $1889 \ldots$ & 18.37 & 10.84 & 59.0 & $1894 \ldots \ldots \ldots \ldots$ & 7.14 & 2.61 & 36.5 \\
\hline $1890 \ldots$ & 15.04 & 9.04 & 60.1 & $1899 \ldots \ldots \ldots \ldots$ & 8.38 & 3.72 & 44.3 \\
\hline $1905 \ldots$ & 24.17 & 4.50 & 18.6 & $1900 \ldots \ldots \ldots$ & 7.79 & 2.45 & 31.5 \\
\hline & & & & $1902 \ldots \ldots \ldots$ & 8.61 & 2.31 & 26.8 \\
\hline & & & & $1903 \ldots \ldots \ldots$ & 8.80 & 5.36 & 60.9 \\
\hline & & & & $1904 \ldots \ldots \ldots$ & 7.85 & 5.29 & 67.4 \\
\hline Average percentage & & . & 53.1 & Average percentage & & $\ldots$ & 47.6 \\
\hline
\end{tabular}

The fall of approximately half the annual precipitation in the humid mid-summer is by no means a constant occurrence at Tucson. In 1881 the summer rainfall was 80.3 per cent of the annual, and in 1884 
it fell to 11.7 per cent. Neither does the percentage of summer rain fluctuate in relation to the occurrence of very wet or very dry years. In 8 of the wettest years since 1876 (14 inches or above) the summer rain was 53.1 per cent of the total, and in 11 of the driest years ( 9 inches or less) the summer yielded 47.6 per cent of the total (see table 2).

The impossibility of securing figures for the winter precipitation in the Santa Catalina Mountains makes it necessary to estimate the annual totals of rainfall at different altitudes from the known figures

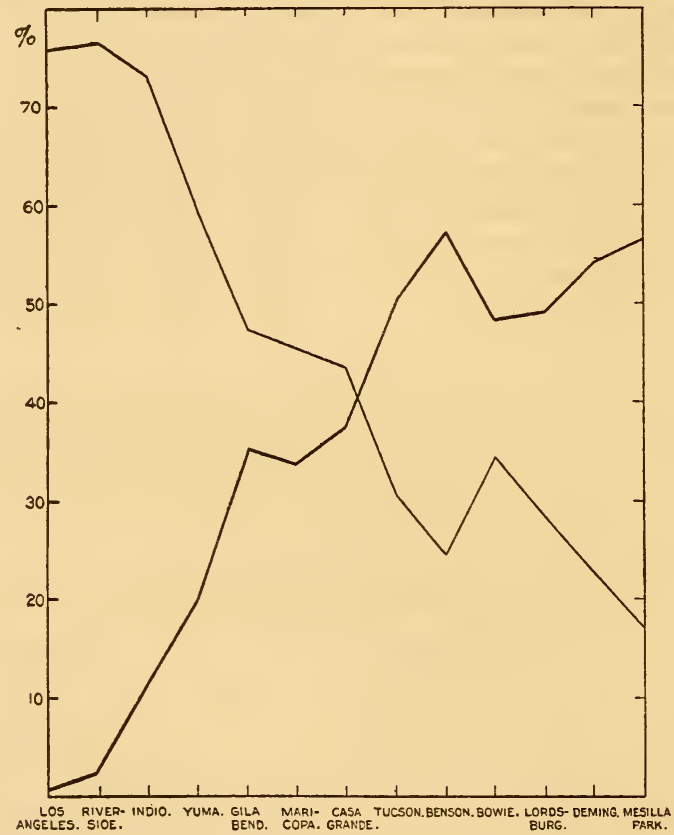

FIG. 3.-Graphs showing percentage of winter rainfall to annual total (light line), and of summer rainfall to annual total (heavy line), for a chain of 13 stations from the Pacific to the Rio Grande.

for the summer rain. The average rainfall at the stations at 7,600 feet and 8,000 feet for the years 1907 to 1914 is 17.45 inches (443 mm.), from which it may be assumed that the annual average is approximately 35 inches $(889 \mathrm{~mm}$.). The summer rain at Tucson during 1907 to 1914 was 54.7 per cent of the annual total. If the seasonal distribution of rain is the same on the mountain that it is at Tucson, the above estimate of the annual total for the mountain is correct within 1 or 2 inches.

The influence of altitude on the seasonal distribution of rainfall in Arizona is a matter which can not be determined without further data 
than are now in hand. During the years 1907 to 1912 the percentage at Benson, Arizona ( 3,523 feet), was 60 per cent, that at Globe, Arizona (3,525 feet), was 42.1 per cent, the average of the two 51.0 per cent. The average of the percentages for Fort Huachuca (5,100 feet), Fort Apache (5,200 feet), and Bisbee (5,500 feet) is 55.5 per cent. Although these figures indicate that up to 5,000 feet there is about the same percentage that holds at 2,400 feet (at Tucson), nevertheless at Flagstaff $(6,907$ feet) the summer rain was only 40.7 per cent of the total in the years mentioned. At Chlarson's Mill (7,200 feet) an incompleterecord indicates that in 1907 , 1909, and 1910 the summer rain was far below the percentages for Tucson for those years. At Greer (9,200 feet), on the Mogollon Plateau, the summer rain was a much

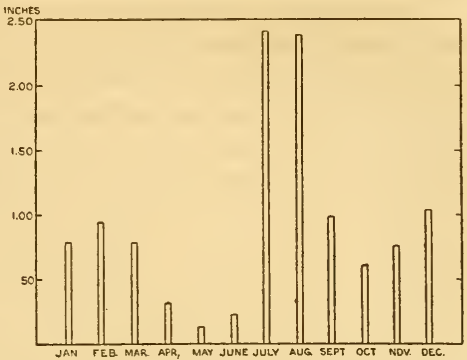

FIG. 4.-Diagram showing monthly distribution of rainfall at Tucson. Averages of record for 38 years, 1876 to 1913 inclusive. greater percentage of the annual total in 1905 than it was at Tucson, while in 1906 and 1908 the percentages were nearly identical. It can only be said, therefore, that a much larger body of data is necessary to determine the possible change of seasonal distribution of rain due to altitude. The evidence at hand indicates that there is little probability of a marked influence. (See table 3.)

TABLE 3.-The average annual rainfall for 1907 to 1912, the average summer rainfall for the same years, and the percentage of the latter to the former for stations at different altitudes in central and southern Arizona.

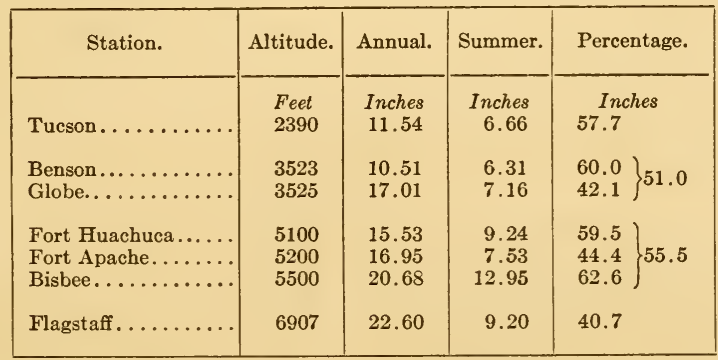

ALTITUDINAL INCREASE OF RAINFALL.

The measurements of summer rainfall on the Santa Catalina Mountains were begun in 1907 by the installation of a metal gauge at 7,600 feet, where the record was secured until 1911, after which it was removed to a nearby ridge at 8,000 feet. During 1908 and 1909 readings were secured at the base of the mountain and at 6,000 feet, in 1910 at 
6,000 feet only. In 1911 a series of stations was selected at vertical intervals of 1,000 feet, from the base of the mountain, 3,000 feet, to the station at 8,000 feet, and in 1912 a station was established on Mount Lemmon, at 9,000 feet. These stations have been continued in the succeeding summers.

The readings of the gauges have been made at irregular intervals, as opportunity afforded; the water has been protected from evaporation by the use of kerosene, and has been measured volumetrically. The installation of the gauges has been made each spring in time to secure the first of the summer rain, and the final readings have been made in September, closing in 1911 on the 22d to the 25th, in 1912 on the 28th to 30 th, in 1913 on the 25 th to the 27 th, and in 1914 on October 10th to 11 th. The location of the gauges at the various altitudes has been such as to give them comparable topographic surroundings. Each station is at the summit of a ridge with a commanding opening to the south and without nearby trees. A record of rain has also been secured at the Xero-Montane Garden at 5,300 feet, near the head of Soldier Cañon and just below the 6,000 -foot station. A recapitulation of all the readings of mountain rainfall is given in table 4 .

\section{TABLE 4.-Summer Rainfall in the Santa Catalina Mountains.}

All readings cover the total precipitation of July, August, and September. Starred figures include some October rainfall. Figures followed by plus are incomplete, owing to the overflowing of gauges.

\begin{tabular}{|c|c|c|c|c|c|c|c|c|c|c|}
\hline \multirow{2}{*}{$\begin{array}{l}\text { Eleva- } \\
\text { tion, } \\
\text { feet. }\end{array}$} & \multirow{2}{*}{1907} & \multirow{2}{*}{1908} & \multirow{2}{*}{1909} & \multirow{2}{*}{1910} & \multirow{2}{*}{1911} & \multirow{2}{*}{1912} & \multirow{2}{*}{1913} & \multirow{2}{*}{1914} & \multicolumn{2}{|c|}{$\begin{array}{c}\text { Averages of } \\
\text { perfect records. }\end{array}$} \\
\hline & & & & & & & & & Inches. & $\begin{array}{l}\text { Milli- } \\
\text { meters. }\end{array}$ \\
\hline 3,000 & & 6.65 & 9.72 & & 6.27 & 5.61 & 6.46 & $10.62 *$ & 7.55 & 192 \\
\hline 4.000 & & & & & 9.45 & 9.77 & 8.59 & $14.73^{*}$ & 10.63 & 270 \\
\hline 5,000 & & & & & 11.97 & 8.24 & 10.27 & $19.13^{*}$ & 12.40 & 315 \\
\hline 5,300 & & $9.21 *$ & 10.75 & 6.05 & 12.51 & 8.67 & 6.09 & & 8.88 & 226 \\
\hline 6,000 & & 6.50 & 3.42 & 5.28 & 11.07 & 8.68 & 8.73 & $22.68 *$ & 8.05 & 204 \\
\hline 7,000 & & & & & 15.86 & 14.57 & & $27.64+$ & 15.21 & 387 \\
\hline 7,600 & 20.92 & 20.63 & 17.91 & 11.40 & 21.30 & & & & 18.43 & 468 \\
\hline 8,000 & ...... & & & & $\ldots \ldots$ & 19.76 & 13.18 & $27.82+$ & 16.47 & 418 \\
\hline 9,000 & & & & & & $20.93+$ & 10.01 & $27.17+$ & 10.01 & 254 \\
\hline
\end{tabular}

The only record of daily rainfall for the Santa Catalinas is one secured in Marshall Gulch, at 7,600 feet, from June to August 1911, by Professor J. G. Brown, of the University of Arizona. A comparison of the daily rainfall at Marshall Gulch and at 8,000 feet with that at the Desert Laboratory (2,663 feet) for the period of these observations is given in table 5. The number of rainy days on the desert was greater than the number on the mountain top-31 and 19 respectively-owing to the 16 days with only a trace of rain at the Laboratory. The total rainfall of the three months was 5.42 inches at the Laboratory (for 
exactly the same days covered by the Marshall Gulch record), and 14.86 inches at the mountain station. The general correspondence between the dates of heavier rains at these stations, 5,000 vertical feet apart, indicates the close relationship of the atmospheric factors which determine the rainfall of all altitudes.

TABLE 5.-Comparative daily incidence of rainfall at the Desert Laboratory (2,663 feet) and at the Montane Garden in Marshall Gulch (7,600 feet), for June, July, and Augusi 1911.

\begin{tabular}{|c|c|c|c|c|c|c|c|c|c|c|c|c|c|}
\hline \multirow{2}{*}{$\begin{array}{l}\text { Day of } \\
\text { month. }\end{array}$} & \multicolumn{2}{|c|}{ June. } & \multicolumn{2}{|c|}{ July. } & \multicolumn{2}{|c|}{ August. } & \multirow{2}{*}{$\begin{array}{l}\text { Day of } \\
\text { month. }\end{array}$} & \multicolumn{2}{|c|}{ June. } & \multicolumn{2}{|c|}{ July. } & \multicolumn{2}{|c|}{ August. } \\
\hline & D. L. & M. G. & D. L. & M. G. & D. L. & M. G. & & D. L. & M. G. & D. L. & M. G. & D. L. & M. G. \\
\hline 1st... & & & .98 & 4.03 & $\ldots \ldots$ & $\ldots \ldots$ & 17 th.. & $\cdots$ & $\ldots \ldots$ & .19 & 1.96 & .52 & \\
\hline $2 \mathrm{~d} \ldots$ & & & $\mathrm{T}$ & $\ldots \ldots$ & $\ldots \ldots$ & ...... & 18th.. & & $\ldots \ldots$ & $\mathrm{T}$ & ...... & $\ldots \ldots$ & $\ldots$ \\
\hline $3 \mathrm{~d}$. & & & $\ldots$. & $\ldots .$. & $\ldots$ & ...... & 19 th. . & $\ldots$ & $\ldots \ldots$ & $\mathrm{T}$ & .62 & .46 & $\ldots \ldots$ \\
\hline 4th. & . & & $\ldots$. & & $\ldots$ & $\ldots \ldots$ & 20th.. & $\ldots \ldots$ & $\ldots \ldots$ & .03 & $\ldots \ldots$ & .53 & .61 \\
\hline 5 th. & & & ... & & $\ldots$. & ...... & 21st... & $\ldots$. & $\ldots \ldots$ & .21 & .14 & .76 & .10 \\
\hline 6 th. & & & $\ldots$ & & $\ldots$ & & $22 \mathrm{~d} .$. & $\ldots \ldots$ & $\ldots \ldots$ & $\ldots$. & $\ldots .$. & .88 & 2.60 \\
\hline 7 th. & & & $\mathbf{T}$ & & $\mathbf{T}$ & & $23 \mathrm{~d} . .$. & ... & $\cdots$ & $\ldots \ldots$ & $\ldots \ldots$ & $\ldots \ldots$ & .64 \\
\hline 8th.. & & & $\ldots$ & .08 & $\ldots$ & .15 & 24th. . & $\ldots$ & $\ldots \ldots$ & $\ldots$ & .14 & $\ldots \ldots$ & ...... \\
\hline 9 th. & & & $\mathrm{T}$ & & $\ldots \ldots$ & .87 & 25 th. . & & & .02 & $\ldots \ldots$ & $\ldots \ldots$ & $\ldots \ldots$ \\
\hline 10th. & $\mathrm{T}$ & $\ldots$ & 10 & & & & 26 th. & & & .33 & .42 & $\ldots$. & ...... \\
\hline 11 th. & .01 & .25 & $\mathrm{~T}$ & 1.27 & $\mathrm{~T}$ & & $27 \mathrm{th}$. & & & $\ldots$. & .20 & $\ldots .$. & $\ldots$ \\
\hline 12th.. & $T$ & $\ldots$ & $\ldots$ & & $\ldots \ldots$ & & 28 th. . & & & $\ldots \ldots$ & $\ldots$ & $\ldots$ & ... \\
\hline 13 th. & $\mathrm{T}$ & 42 & $\mathrm{~T}$ & & 30 & & 29 th. & $\mathrm{T}$ & & $\ldots \ldots$ & & & $\ldots \ldots$ \\
\hline 14 th. & $\mathrm{T}$ & .02 & $\mathrm{~T}$ & & $\ldots$ & & 30th. & $\mathrm{T}$ & & $\ldots \ldots$ &. & $\cdots$ & $\ldots \ldots$ \\
\hline 15 th. & $\ldots \ldots$ & $\ldots$. & .10 & & & & 31 st... & $\ldots \ldots$ & $\ldots$ & $\ldots \ldots$ & & $\ldots$ & $\ldots .$. \\
\hline 16th. . & & & $\ldots \ldots$ & .34 & $\ldots$. & $\ldots \ldots$ & & 0 & & ( & & & \\
\hline
\end{tabular}

Total rainfall: Desert Laboratory, 5.42 in.; Montane Garden, 14.86 in. Total number of rainy days: Desert Laboratory, 15 (or 31, including days with T); Montane Garden, 19.

Another comparison which it is possible to institute between the summit of the Santa Catalinas and the desert is the summer rainfall totals from 1907 to 1914 inclusive (see fig. 9). The directions of the curves which show the march of the summer precipitation from year to year indicate an almost complete lack of relationship between the mountain and the plain. It is obvious that the curve of altitudinal increase of rainfall determined in such a year as 1910 would be very unlike the curve determined in 1911.

It has been suggested by Smith * that there may be a relative increase of rainfall at the higher altitudes as the summer advances, which is to say that the gradient of increase of rainfall with altitude is steeper for the late summer than it is for the early summer. In order to test this possibility the series of ten readings taken in the humid midsummer of 1911 and the one set taken in the early arid after-summer have been grouped into totals for five periods of approximately one month each (table 6). An inspection of the table shows that the maximum rainfall occurred between July 18 and August 24 at 3,000, 4,000,

\footnotetext{
* Smith, G. E. P. Groundwater Supply and Irrigation in the Rillito Valley. Ariz. Agric. Exper. Sta. Bull. 64, 1910.
} 
5,000, and 8,000 feet, and between June 20 and July 18 at 6,000 and 7,000 feet. In similar manner the less frequent readings of 1912 and 1913 have been divided into the early summer and late summer falls, by the latest July reading, and the averaged curves for early summer and late summer rain are of nearly the same shape, but the late summer curve is not so steep. This short record does not seem, therefore, to corroborate the suggestion of Smith.

TABLE 6.-Intraseasonal distribution of summer rainfall at the Desert Laboratory and at 6 elevations in the Santa Catalina Mountains for 1911.

Rainfall of the maximum period in heavy type.

\begin{tabular}{|c|c|c|c|c|c|c|}
\hline Station. & $\begin{array}{c}\text { Apr. } 25-27 \\
\text { to } \\
\text { June } 20-21 .\end{array}$ & $\begin{array}{c}\text { June } 20-21 \\
\text { to } \\
\text { July } 18-19 .\end{array}$ & $\begin{array}{c}\text { July } 18-19 \\
\text { to } \\
\text { Aug. 22-24. }\end{array}$ & $\begin{array}{c}\text { Aug. } 22-24 \\
\text { to } \\
\text { Sept. } 22-25 .\end{array}$ & $\begin{array}{c}\text { Sept. } 22-25 \\
\text { to } \\
\text { Oct. } 12-14 .\end{array}$ & Totals. \\
\hline Des. Lab. . & 0.01 & 1.37 & 4.08 & 2.90 & 1.61 & 9.97 \\
\hline 3,000 feet... & .00 & 1.08 & 3.39 & 1.80 & 1.46 & 7.73 \\
\hline 4,000 feet... & .00 & 2.15 & 4.65 & 2.6 & 1.69 & 11.14 \\
\hline 5,000 feet... & .00 & 3.62 & 5.40 & 2.95 & 2.75 & 14.72 \\
\hline 6,000 feet... & .00 & 5.71 & 3.45 & 1.91 & 1.92 & 12.99 \\
\hline 7,000 feet... & .00 & 7.36 & 3.68 & 4.82 & 2.16 & 18.02 \\
\hline 7,600 feet... & .69 & 8.30 & 8.83 & 3.48 & 2.56 & 23.86 \\
\hline
\end{tabular}

The increase of rainfall which accompanies increase of altitude is a phenomenon of general occurrence throughout the southwestern United States. The curves by which such increase may be expressed differ from each other most strikingly, according to the horizontal distance of the successive stations from each other, according to the coastal or continental position of the series of stations, or according to the size of the mountain range on which the successive elevations are secured. Although it is possible to deduce mathematical formulæ for the vertical increase of rainfall, it is necessary to introduce into all such formulæ a constant for the particular region or mountain involved, and the figures thus secured are merely in the nature of hypothetical means near which the normal conditions may fall. It would be of very great interest in the extension of plant geography to possess data on the actual amounts of rainfall at successive elevations in a large number of mountains and shelving plains throughout the southwest. The mean rainfall conditions which are expressed in a gradient based on a long climatological record are of great importance in connection with vegetation, but only when consideration is also given to the extremes of rainfall, and particularly to the lower extremes, if a semi-arid country is under consideration. The securing of typical normal gradients of altitudinal increase of rainfall is not of so much importance in plant geography, therefore, as a knowledge of the actual oscillations of the rainfall conditions from year to year throughout the series of stations or localities involved. 
Smith* has deduced two curves of altitudinal increase of rain, one applicable to Pima and Pinal Counties, Arizona (the counties in which the Santa Catalinas lie), the second to Graham and Cochise Counties. These curves are based on records of various lengths, chiefly from stations located in the valleys of these mountainous counties. Smith's curves are reproduced in figure 5 , in which they have been brought half way down toward the base line in order to make them comparable with the curve expressing the average summer rainfall of the Santa Catalina Mountains for 1911, 1912, and 1913. The portion of Smith's Graham-Cochise curve extending above 5,500 feet is based on a single short record at 6,000 feet.

The curve of altitudinal rise of rain for 1911, 1912, and 1913 in the Santa Catalinas is merely a simple average of the actual readings for the three summers, without any attempt to correct in accordance with
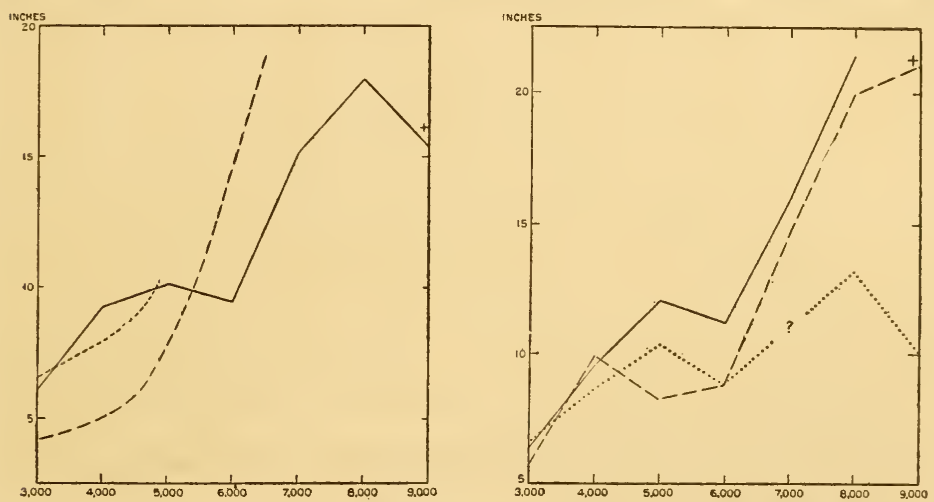

FIG. 5.-Graph showing altitudinal increase of summer rainfall on the Santa Catalina Mountains in 1911, 1912, and 1913 (solid line); together with Smith's curves for Pima and Pinal Counties, Arizona (dotted line), and for Cochise and Graham Counties (broken line).

FIG. 6.-Graphs showing vertical increase of summer rainfall in the Santa Catalina Mountains in 1911 (solid line), 1912 (broken line), and 1913 (dotted line).

the departure of the neighboring lowland rainfall from the normal during these years, without the application of any rainfall formula, and without the smoothing of the lines. Reference to table 4 will show that the record for 7,000 feet is based on two years only, and the record for 9,000 feet on one correct summer's reading and the reading of one summer in which the gauge overflowed.

A comparison of Smith's curves with the curve for the Santa Catalinas shows the latter to have a sharper rise from 3,000 to 4,000 feet, and to have a relatively level stretch from 4,000 to 6,000 feet, where the former curves have their sharpest ascent. 
Figure 6 gives the actual curves for the three summers for the Santa Catalinas. It will be noted that in each curve there is a sharp rise from 3,000 to 4,000 feet, a rise which continued at the same gradient to 5,000 feet in 1911 and 1913. From these submaxima, reached at 5,000 feet in 1911 and 1913 and at 4,000 feet in 1912, there is a fall to a subminimum at 6,000 feet in the two former years and at 5,000 feet in the latter year. There is then a pronounced rise in the curve to 7,000 and 8,000 feet. The rainfall at 9,000 feet in 1912 was probably an inch or more greater than indicated by the curve, in any case was greater than that at 8,000 feet; whereas in 1913 the precipitation at 9,000 feet was less than that at 8,000 feet, in fact less than that at 5,000 feet.

The horizontal distances between the rainfall stations were unequal (see plate A), the angle of rise from 3,000 to 4,000 feet being very
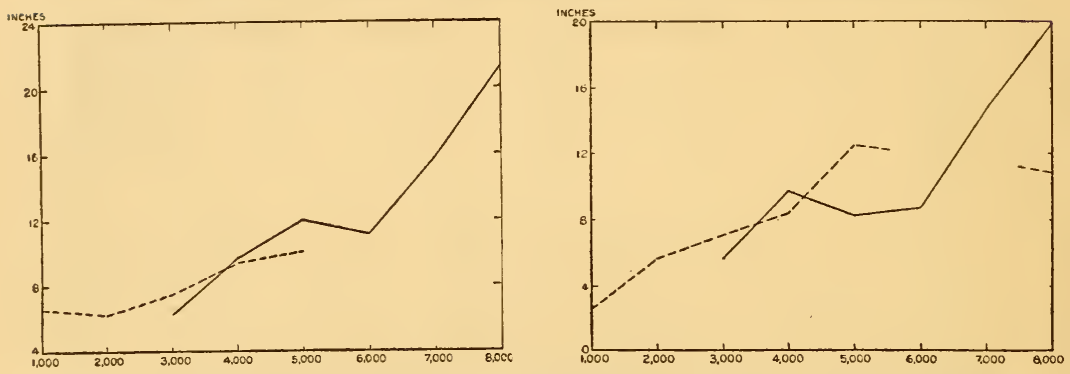

FIG. 7.-Graph showing vertical increase of summer rainfall in the Santa Catalina Mountains in 1911 (solid line), together with averaged vertical increase in a series of 13 Weather Bureau stations in Arizona (broken line).

FIG. 8.-Graph showing vertical increase of summer rainfall in the Santa Catalina Mountains in 1912 (solid line), together with averaged vertical increase in a series of 21 Weather Bureau stations in Arizona (broken line).

sharp, that from 4,000 to 5.000 slightly less sharp, and that from 5,000 to 6,000 still less sharp and exactly equal to the angle of rise from 6,000 to 7,000 feet. The stations at 8,000 and 9,000 feet are located at the west end of the main ridge and are consequently not in line with the lower stations. The sharp rise in elevation between the 3,000 and 4,000 foot stations is doubtless partially accountable for the rapid increase of rainfall between them. The steep rise of the rainfall graphs between 6,000 and 7,000 feet may indicate an influence due to the position of the 7,000-foot station on the north rim of Bear Cañon, with a very abrupt wall immediately below it. There is no topographic cause, however, to which it is possible to attribute the dip in the rainfall curves for 6,000 feet in 1911 and 5,000 feet in 1912 .

In order to institute a comparison between the mountain gradients of rainfall and those of the valley stations of the Weather Bureau the data have been collated which are expressed in the curves of figures 7 


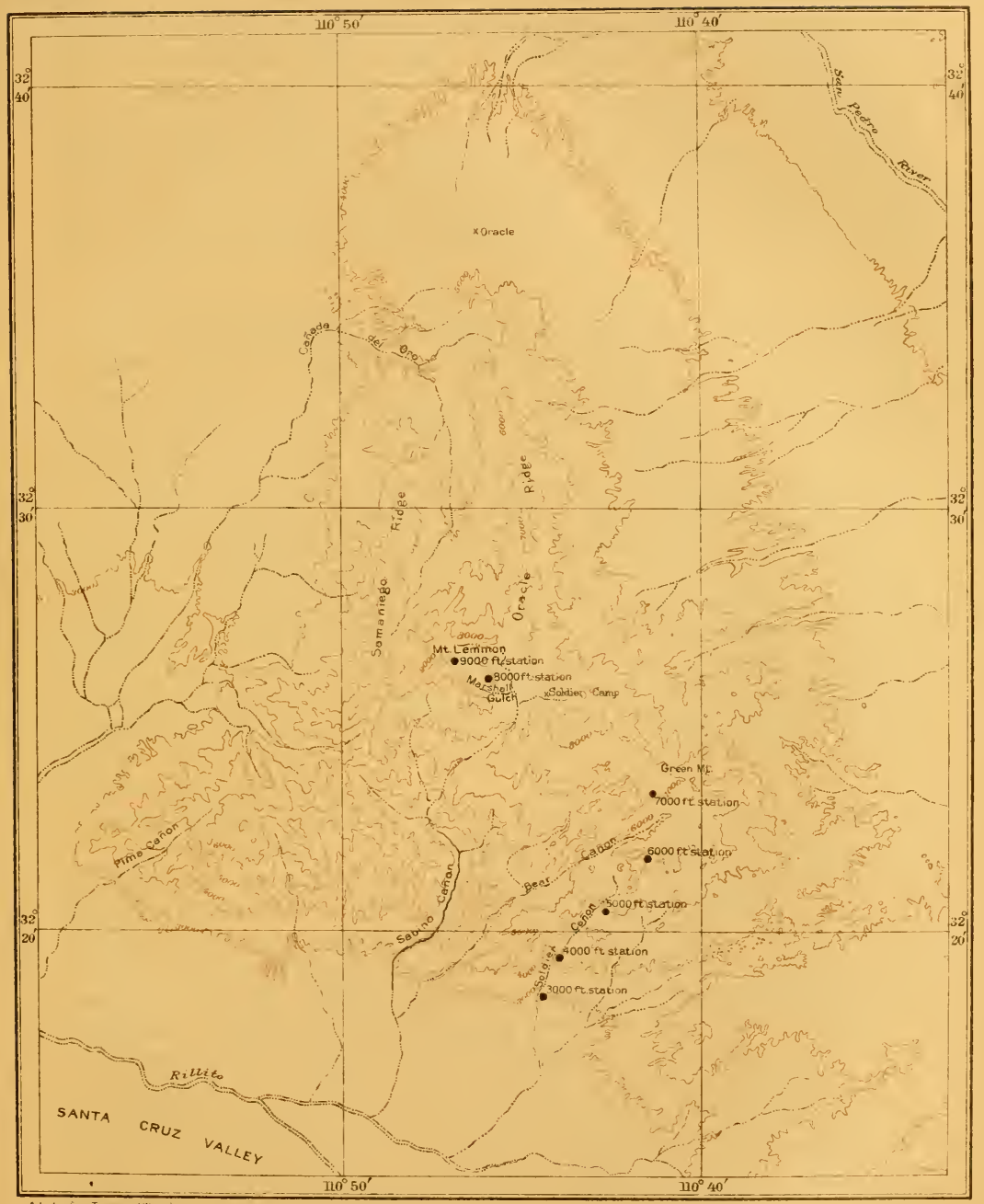

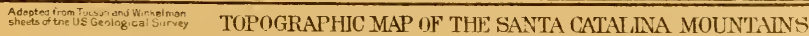

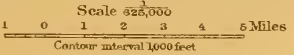


and 8. These figures compare the summer rainfall curves of the Santa Catalinas and those of selected stations for the same summers. In figure 7 the rainfall of July, August, and September 1911 has been used, for 13 stations located in southeastern Arizona, east of Phœnix and south of Fort Apache. The rain has been averaged for each group of stations lying within the same thousand-foot interval of altitude. Figure 8 shows the curve for the Santa Catalinas for 1912 and the curve for 21 stations in the same area. A single record above 5,000 feet has been available for this curve, that at Chlarson's Mill, in the Pinaleno Mountains.

The significance of the comparison of these rainfall records for a single season is entirely different from that of averages for long series of years. Such a comparison as this makes possible the contrasting of records which are strictly contemporaneous and serves to show the way in which the same complex of meteorological conditions affected the precipitation at various altitudes, and how these conditions affected the rainfall of a single mountain range in comparison with that of an extended adjacent area lying at different levels. The extremely small number of rainfall records secured at localities above 5,500 feet in southern Arizona does much to vitiate such a comparison. In 1911 the gradient of rise was greater between 3,000 feet and 5,000 feet in the Santa Catalinas than it was in the Weather Bureau stations. In 1912 the rise was sharper in the mountains from 3,000 to 4,000 feet than it was in the valleys, but the fall from 4,000 to 5,000 feet was paralleled by a rise in the curve of the valley stations. The fall at 7,200 feet at Chlarson's Mill was far below that at 8,000 feet in the Santa Catalinas for the same period.

The shape of the averaged curve of rainfall in the Santa Catalinas for the three summers is correlated with the nature and movement of the convectional storms to which the summer precipitation is due. It would appear that certain rains are derived from low-lying clouds which form over the desert and are then driven against the mountain wall by the prevailing southwest winds of summer. These rains increase in intensity as they pass up the mountain slopes and yield their maximum downpour at about 4,000 or 5,000 feet, according to the conditions. The rainfall at the Xero-Montane Garden was greater than that at the 6,000-foot station (700 feet above it and only half a mile distant) for four of the six summers in which records have been kept in the two localities (see table 4). The Garden is located at the head of Soldier Cañon, and just above it there is a sharp increase in the gradient of the mountain slopes. It is probable that the head of the cañon is the terminating point in the course of many of the desert rain storms. The rapid increase of rainfall between 6,000 and 7,000 feet may be due to a similar topographic cause, as mentioned in a preceding paragraph, or it may give indication that the rains of the 
higher elevations are derived from a higher cloud level, probably from convectional clouds which form at times when the atmospheric conditions cause condensation at a greater distance from the earth. When a long series of records shall have been secured from the 9,000-foot station it will probably show that its average rainfall is greater than that at 8,000 feet, but the 9,000-foot record for 1913 indicates that there will be occasional years, at least, in which the maximum for the mountain is recorded at 8,000 feet. This probably means that at 10,000 feet on adjacent mountains there is a constantly lower rainfall than at 8,000 or 9,000 feet.

The check in the vertical increase of rainfall which has been described as occurring between 4,000 and 6,000 feet appears to be absent from all curves derived from widely separated valley stations. The writer has seen no such plateau in any curves derived from southwestern data, but there is always the possibility that a plateau has been smoothed out of the curves or that the data have been subjected to the influence of a straight-line equation. The character of the increase of precipitation with altitude in a single small range of mountains is no more a special case than is the increase in a widely separated series of stations in any locations whatsoever. In so far as concerns the study of meteorological dynamics, such a mountain

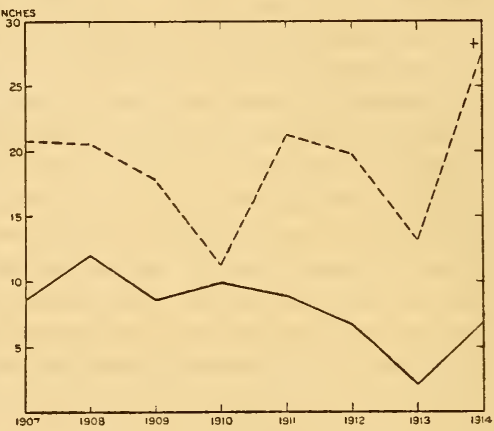

Fro. 9.-Graph showing lack of relation between summer rainfall at Marshall Gulch (7,600 feet) and at Desert Laboratory (2,663 feet) from 1907 to 1914 .

range as the Santa Catalinas offers exceptional opportunities for investigation, and much more might be learned in a single summer of intensive meteorological study on its slopes than could be ascertained by an examination of records of rainfall covering a period of a thousand years.

As regards vegetation, the most important feature of the study of rainfall conditions is the determination of the extremes of variation in the amount and seasonal distribution of rain, and the ascertaining of the effect of these extremes upon the conditions of soil moisture. Years of heavy precipitation are important for the maintenance of the forest which clothes the higher mountain slopes and for the general restoration of the supplies of soil moisture and ground water. The years of low precipitation, and especially the series of consecutive years with deficient rainfall, are of first importance to the vegetation which occupies the Encinal region of the mountains. During such years, and particularly during the arid fore-summer of such years, the lowest 
individuals of all Encinal and Forest species are subjected to conditions of water supply which are perhaps below any conditions that have previously occurred during their lives, or are surely-in the case of perennials - the most trying conditions when considered in the light of the plants having grown to greater size and heavier water-demand than during the dry periods of their earlier existence.

\section{SOIL MOISTURE.}

It is obvious, from a consideration of the monthly distribution of rainfall in the Santa Catalinas, that at all elevations there are annually two periods of high soil moisture, coinciding with the humid midsummer and the humid winter, and two periods of decreasing soil moisture content, coinciding with the arid fore-summer and arid aftersummer. The influence of the earliest rains of summer and winter is quickly exerted in an elevation of the soil moisture, but at the close of these seasons it is with relative slowness that the soil falls to low percentages of moisture, particularly at the highest altitudes. The minimum moisture content of the year is usually to be detected just before the first heavy rain of the humid mid-summer, but the content in September or October may sometimes be quite as low.

At low elevations in the Santa Catalinas the annual march of soil moisture may be expected to be analogous to that which has been described by the writer for Tumamoc Hill, the site of the Desert Laboratory.* Marked differences will result from a comparison of the two localities, however, owing to the difference in the character of the soil. The very fine clay of Tumamoc Hill is conservative in its changes of moisture content, both with respect to increases and decreases of moisture. while the coarse loam found at the lower elevation in the Santa Catalinas possesses a greater permeability and a lesser holding power. The soils of elevations of 7,000 feet and more are richer in organic matter than those of the Desert and Encinal regions of the mountain, and are doubtless more like the clay of Tumamoc Hill in the smoothness of their curves of change in moisture content.

The few readings of soil moisture content that have been made were directed toward a determination of the soil conditions in the most arid portion of the year. It is obvious that it is these annual minima which are of the greatest importance to plants, particularly to such plants as are near the lowest limit of their vertical occurrence. Much less interest attaches to the high moisture contents which might be found in the midst of the rainy seasons. It is true that these high moistures are the ones which call forth general vegetative activity and condition the appearance of ephemeral plants at the lower altitudes. It is likewise possible that high and protracted soil moistures may be of some importance as a limiting factor for desert species at the upper edges

* Shreve, Forrest. Rainfall as a Determinant of Soil Moisture. The Plant World, 17:9-26, 1914. 
of their ranges. It was impossible, nevertheless, to secure a set of soil samples in the humid mid-summer which would be representative of the maximum moisture conditions and at the same time comparable for the various altitudes. A set of samples taken at the same interval after a rain of the same amount, at each of the several elevations, would comply with the requirements.

All samples of soil for moisture content were taken from a depth of $15 \mathrm{~cm}$. The conditions at this depth are of importance for ephemeral herbaceous plants and for some shrubs, but the trees and larger shrubs are, of course, dependent for their supplies on much more deep-seated bodies of soil. The rocky character of the substratum means that the largest perennial plants are dependent to a great extent upon the moisture contained in the soil which occupies the crevices of the rock in situ. It is particularly noticeable that the lowest trees of the Encinal region grow in the uppermost part of talus slopes or along the bottoms of cliffs. In such situations it is doubtless possible for the roots of these trees to reach soil-filled crevices which are fed by gravity with the water of large veins of soil above.

The samples of soil were secured by digging with a hand trowel and transferring quickly to bottles, which were tightly stopped, and then coated over the stopper with vaseline. The soils were dried in the original bottles by heating to $100^{\circ} \mathrm{C}$. until they showed constant weight. The percentages of moisture have been calculated on the dry weight as unity. The physical texture of all samples taken was very similar, but there was a greater amount of humus in those from the higher elevations.

Three series of soil samples were taken at various times to determine the conditions prevailing in the arid fore-summer. These samples were taken at 1,000-foot intervals, from the vicinity of the rainfall stations, and were secured in pairs, one sample being from a south slope and one from a north slope. The localities chosen for sampling were typical of the slopes at the several elevations, and in every case the pair of samples was secured in the midst of the dissimilar vegetations which occupy the opposed slopes.

On April 27 to 29, 1911, a series was secured from 3,000 feet to 7,000 feet (see table 7). For the three months preceding the taking of these samples there had been only light and infrequent rains over the surrounding region, the rainfall of the mountains themselves for this period being unknown. At Tucson there was a rainfall of 0.28 inch on April 2 , and there was no appearance of rain on the mountains after that date. On June 9 to 11 another series of samples was secured at the same stations, together with a pair from the station at 8,000 feet. There had been no rain between the securing of the two sets of samples.

A comparison of the percentages of moisture in April and in June shows them to be of about the same order of magnitude. The relative 
dryness of the three months preceding the taking of the first set of samples, together with the 25 days of rainless weather just preceding the taking of the samples, had reduced the moisture of the superficial soil to an amount which was near the minimum for the year, as represented by the percentages for June. The percentages for June were all slightly lower than those for April. The reading of 5.2 per cent for the south slope at 5,000 feet in April is undoubtedly too high. The fall in moisture on the north slope at 7,000 feet from 9.2 per cent in April to 3.2 per cent in June is doubtless significant of the long reten-

TABLE 7.-Soil moisture in the arid fore-summer at a depth of $15 \mathrm{~cm}$. on north and south exposures at seven altitudes on the Santa Catalina Mountains.

\begin{tabular}{|c|c|c|c|c|}
\hline $\begin{array}{l}\text { Elevation } \\
\text { and } \\
\text { exposure. }\end{array}$ & $\begin{array}{c}\text { Apr. } 27 \text { to } 29 \text {. } \\
1911 .\end{array}$ & $\begin{array}{c}\text { June } 9 \text { to } 11, \\
1911 .\end{array}$ & $\begin{array}{c}\text { May } 15 \text { to } 20, \\
1914 .\end{array}$ & $\begin{array}{l}\text { Average of } \\
\text { the three de- } \\
\text { terminations. }\end{array}$ \\
\hline 3,000 south $\ldots \ldots$ & 2.5 & 2.3 & 1.2 & 2.0 \\
\hline 4,000 south........ & 2.7 & 2.4 & 1.0 & 2.0 \\
\hline 4,000 north.......... & 3.2 & 2.8 & 1.5 & 2.5 \\
\hline 5,000 south. . . . . . & 5.2 & 1.8 & 2.4 & 3.1 \\
\hline 5,000 north. . . . . & 3.8 & 1.3 & 5.5 & 3.5 \\
\hline 6,000 south...... & 2.3 & 1.3 & 1.9 & 1.8 \\
\hline 6,000 north . . . . . . & 5.1 & 2.3 & 3.0 & 3.5 \\
\hline 7,000 south. . . . . . & 3.1 & 2.6 & 2.1 & 2.6 \\
\hline 7,000 north. . . . . . & 0.2 & 3.2 & 4.1 & 5.5 \\
\hline 8,000 south . . . . . . & $\ldots$ & 6.1 & 8.8 & 7.4 \\
\hline 8,000 north. . . . . . & $\ldots$ & 8.1 & 14.5 & 11.3 \\
\hline 9,000 south . . . . . . & $\cdots$ & $\ldots$ & 9.4 & 9.4 \\
\hline 9.000 north....... & $\ldots$ & $\ldots$ & 27.9 & 27.9 \\
\hline
\end{tabular}

The percentages are based on dry weight.

tion of moisture derived from winter rains, characteristic of the forested elevations. In June the north slope at 8,000 feet had fallen to a slightly lower percentage of moisture than the north slope at 7,000 feet in April.

Between May 15 and 20, 1914, another series of moisture samples was secured at the same localities and extended to the 9,000 -foot station. The preceding winter had been slightly below the average in precipitation, but the rainfall for March had been above the average. At the time of the taking of the samples there had been no rains for six weeks. This series of percentages is similar to those secured in 1911, and the three may be taken together as indicating the average soil moisture conditions of the arid fore-summer.

A significant feature of all three of the series of moisture determinations is the fact that there is no appreciable increase of soil moisture up to an elevation of 7,000 feet, beyond which elevation there is a sharp rise in the percentages, particularly those for the north slopes. In other words, so far as the superficial soil moisture conditions are concerned, the arid fore-summer carries the desert up to the lower limit of the Pine Forest.

One of the underlying causes of the importance of slope exposure for vegetation is revealed in a comparison of the percentages of soil 
moisture for north and south slopes. For the stations at 4,000, 5,000, and 6,000 feet the percentages for the two slopes scarcely differ by more than the error which may be attributed to the inequalities of the moisture in adjacent bodies of soil. Nevertheless, in all but two cases there is a slightly greater moisture content on the north slope than on the south. At 7,000 feet the difference between the two exposures becomes greater, and is still greater at 8,000 and at 9,000 feet. An inspection of the averages (see fig. 10) shows that the south slope at 7,000 feet has a lower soil moisture than the north slope at 6,000 feet. The south slope at 8,000 feet, however, has a higher moisture than the north slope at 7,000 feet.

The fact that there is a very slight difference between the soil moisture of north and south slopes at lower elevations and a greater difference with increasing altitude would sug-

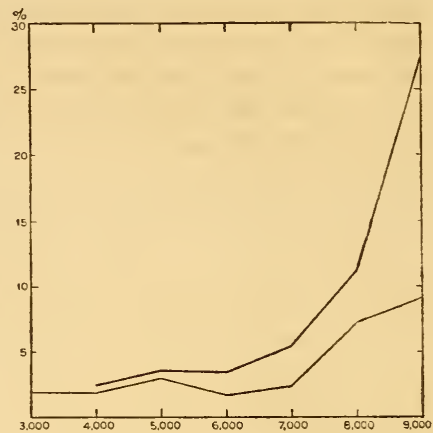

FIG. 10.-Graph showing vertical increase of soil moisture at $15 \mathrm{~cm}$. in the Santa Catalina Mountains on north slopes (heavy line) and south slopes (light line). Average of three determinations in arid fore-summer. gest that there might be a more pronounced set of vegetational phenomena resulting from slope exposure at higher elevations than at lower ones. This is, indeed, the case, and will be discussed under a later heading (see p. 98).

TABLE 8.-Soil moisture in the arid fore-summer and arid after-summer at a depth of $15 \mathrm{~cm}$. on north and south exposures, in shade and open, at various altitudes on the Santa Catalina Mountains.

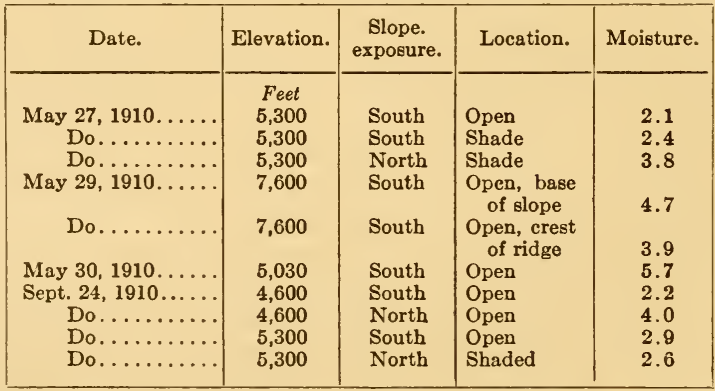

In the summer of 1910 several samples of soil were taken for the determination of the moisture conditions on opposed slopes and in shaded and open soil, as well as on the top and at the base of a slope. These data are shown in table 8. The September readings, when taken 
in comparison with the April, May, and June readings, show moistures of about the same amount, indicating that the after-summer is often a season of as great soil aridity as the fore-summer.

The data for shaded and unshaded soil, both in May and September, corroborate similar determinations made on Tumamoc Hill and go to show that in the arid seasons the influence of shade in sustaining the moisture of soil is so slight as to be negligible. The influence of shade in retarding the desiccation of the soil just after a rain is not without its importance, but in the Desert and Encinal regions the soil in the shade of trees will soon reach as low a percentage as that in the full sun.

\section{EVAPORATION.}

It has been frequently pointed out, in recent botanical literature, that the measurement of the evaporative power of the air affords a concise expression of the combined effects of temperature, humidity, and air movement in so far as these factors affect the loss of water by plants. The obvious importance of these factors-and consequently of evaporation-in the environmental complex of the Santa Catalinas led to the early installation of a series of atmometers (or evaporimeters) at several elevations in these mountains. In the summer of 1906 Dr. B. E. Livingston secured data from three porous cup atmometers at elevations of 6,000, 7,500, and 8,000 feet.* In 1908 and 1910 the writer installed series of atmometers at five elevations, from which readings were secured which are not sufficiently complete and reliable to be worthy of publication. In 1911 a new series of atmometers was installed at the six rainfall stations, from 3,000 to 8,000 feet inclusive, at 1,000 -foot intervals. These instruments were exposed in pairs, on north and south exposures, and were operated in the most careful manner, in accordance with the experience of the two preceding years. The atmometers were read at fortnightly intervals, or nearly so, and at each reading fresh cups were installed. The actual readings were reduced to standard by the use of an average between the original and the final coefficients of correction. Only good distilled water was used, and it was conveyed in tin canteens (rather than galvanized iron ones) from which the resin remaining from the soldering had been removed with carbon bisulphide. The bottles used for the atmometers had a capacity of 1 gallon at the lower stations and of 2 quarts at the higher stations, such ample amounts of water providing against the possible danger of the atmometers going dry. The stoppers in the mouths of the bottles were made very tight, to prevent the cups from blowing loose, but were provided with grooves to admit air. These grooves were stopped with loose cotton, to prevent the entrance of ants, and the stoppers were covered by aprons to exclude rain. The atmometers were all exposed in situations such that they received full insolation

* Livingston, B. E. Evaporation and Plant Habitats. The Plant World, 11: 1-9, 1908. 
throughout the day, except in the case of the instrument on the north slope at 8,000 feet, which it was impossible to place in such a way as to avoid a slight amount of light shade in the mid-morning and in the mid-afternoon.

Readings were secured at the stations from 3,000 to 7,000 feet from April 25 to 27 until September 5 to 6, and at 8,000 feet from June 7 until September 5. The actual amounts of the readings are given in table 9 , in terms of the average loss per day in cubic centimeters from a standard cup.

TABLE 9.-The average daily evaporation (in cubic centimeters), for the periods indicated, on north and south exposures, at 6 elevations in the Santa Catalina Mountains.

\begin{tabular}{|c|c|c|c|c|c|c|c|c|c|c|c|}
\hline \multirow{2}{*}{ Dates. } & \multirow{2}{*}{$\begin{array}{c}\begin{array}{l}3,000 \\
\text { feet. }\end{array} \\
S\end{array}$} & \multicolumn{2}{|c|}{4,000 feet. } & \multicolumn{2}{|c|}{5,000 feet. } & \multicolumn{2}{|c|}{6,000 feet. } & \multicolumn{2}{|c|}{7,000 feet. } & \multicolumn{2}{|c|}{8,000 feet. } \\
\hline & & $\mathrm{S}$ & $\mathrm{N}$ & $\mathrm{s}$ & $\mathrm{N}$ & $\mathrm{s}$ & $\mathrm{N}$ & $\mathrm{s}$ & $\mathrm{N}$ & $\mathrm{s}$ & $\mathrm{N}$ \\
\hline Apr. $25-27$ to May $18-19$. & 97.2 & 75.2 & 68.6 & 50.1 & 51.2 & 57.7 & 52.4 & 60.8 & 48.0 & & \\
\hline May $18-19$ to June $6-7$. & 120.5 & 84.8 & 91.2 & 74.2 & 83.1 & 67.7 & 68.6 & 72.5 & 57.5 & & \\
\hline June $6-7$ to June $20-22$. & 85.7 & 81.3 & 88.4 & 60.8 & 88.8 & 52.8 & 47.4 & 55.2 & 44.3 & 29.3 & 29.4 \\
\hline June $20-22$ to July $6-7$. & 61.1 & 67.6 & 76.5 & 50.9 & 46.1 & 50.4 & 43.3 & 46.8 & 43.3 & 27.5 & 15.9 \\
\hline July $6-7$ to July $18-21$. & 43.2 & 41.0 & 43.7 & 32.5 & 25.5 & 22.6 & 24.5 & 22.8 & 19.5 & 10.7 & 5.9 \\
\hline July $18-21$ to Aug. $8-9$. & 59.8 & 54.7 & 53.5 & 44.2 & 37.2 & 34.2 & 33.6 & 37.3 & 34.1 & 23.3 & 19.0 \\
\hline Aug. $8-9$ to Aug. $22-23$. & 61.0 & 56.0 & 59.3 & 45.2 & 44.2 & 37.6 & 36.1 & 39.9 & 27.0 & 13.1 & 7.4 \\
\hline Aug. $22-23$ to Sept. $5-6$. & 55.6 & 42.8 & 56.9 & 50.8 & 33.4 & 39.5 & 28.3 & 39.3 & 24.0 & 18.9 & 12.5 \\
\hline Sept. $5-6$ to Sept. $22-25$. & 45.4 & 56.9 & 39.9 & 31.6 & 20.2 & 22.5 & 20.8 & 28.0 & 30.4 & 11.2 & 5.8 \\
\hline
\end{tabular}

In order to ascertain the altitudinal gradient of evaporation rate the readings from the north and south slopes at each altitude have been averaged. The averaged total evaporation of the summer for each station has been subdivided, so as to show the amount for the arid fore-summer as shown by the first three series of readings, and for the humid mid-summer as shown by the last six series. The curves in figure 12 show the altitudinal fall in evaporation rate during the two seasons, in terms of the average daily loss from the atmometer. These curves bring out in striking manner the low evaporation rates of the humid mid-summer as contrasted with the arid fore-summer, the latter being nearly twice as great as the former. There is a strong parallelism between the two curves, but the one for the humid season is slightly flatter than the one for the arid season. This means that, so far as concerns the evaporation conditions alone, there is a less differentiation between Desert and Forest in the summer rainy season than there is in the arid portion of the summer. The pronounced drop in evaporation from 7,000 to 8,000 feet is particularly significant, as the former elevation marks the lower edge of the Forest, while the latter is in the midst of the best stands of pine. It is possible that the forest itself interferes with air movements near the ground in such a way as to be responsible for the sharp fall in evaporation.

In order to exhibit the seasonal march of evaporation rate at the several altitudes the curves of figure 11 have been drawn. These 
curves show the averages between the south and north slopes for each station at each reading, being expressed in cubic centimeters of evaporation per day. Here again is brought out the pronounced fall in

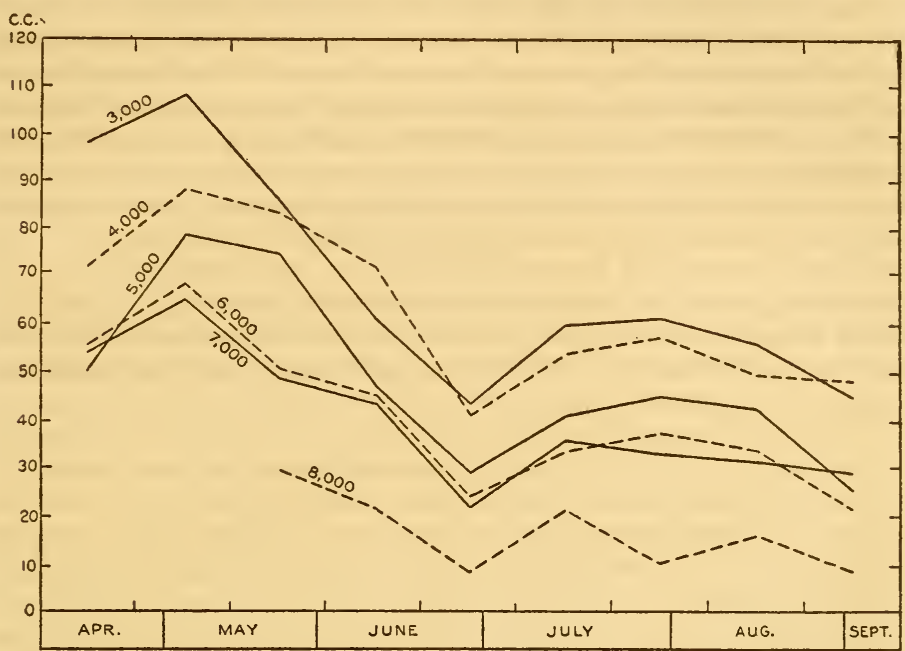

Fra. 11.-Graphs showing seasonal march of evaporation rate at 6 altitudes in the Santa Catalinas in 1911. Amounts are average daily losses from the atmometer, and each reading is the average of one on a north slope and one on a south slope.

rate which follows the advent of the summer rains and the cloudy and relatively humid weather by which they are accompanied. After the period of heavy rains by which the humid mid-summer was opened in the last days of Juneand early days of July there was a slight rise in evaporation, followed by a slight fall in late August and early September. The curves for 3,000 and 4,000 feet accompany each other closely after the first two readings, and the curves for 6,000 and 7,000 feet accompany each other closely throughout the summer. The curve for 8,000 feet stands always well apart from that for 7,000 feet. The grouping of these curves is, therefore, analogous to the natural subdivisions of the vegetation. Thereadings taken in the

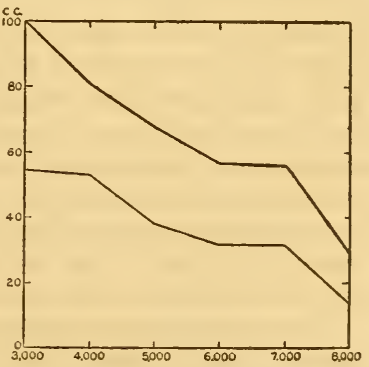

Fra. 12.-Graphs showing altitudinal decrease in rate of evaporation in the Santa Catalinas in arid foresummer (heavy line) and humid mid-summer (light line) of 1911. Desert region at 3,000 and 4,000 feet, those taken in the Encinal and the lower edge of the Forest at 5,000,6,000, and 7,000 feet, and the one series 
taken in the heart of the Forest stand apart in three loosely defined groups in close parallelism to the zonation of the vegetation itself.

During the arid fore-summer the evaporation at 5,000 feet is similar to that at 4,000 feet, while during the humid mid-summer it is more nearly like that of the 6,000 -foot station. In other words, the advent of the rains causes the evaporation conditions of the Upper Encinal and lower Forest region to extend downward into the Lower Encinal.

The significance of slope exposure in determining evaporation rate is indicated in figures 13 and 14. In these graphs the vertical gradients of evaporation at the six elevations are shown separately for the instruments on the south slopes and the north slopes at each station. The gradients for the arid fore-summer and for the humid mid-summer are shown, as well as the curves for the entire summer. In the arid season there is even a slightly greater evaporation on north slopes at 4,000 and 5,000 feet than there is on south slopes, but this condition
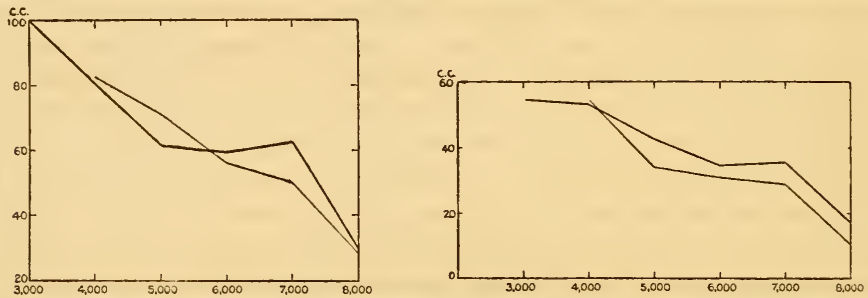

Fra. 13.-Graphs showing altitudinal decrease in rate of evaporation in the Santa Catalinas on south-facing slopes (heavy line) and on north-facing slopes (light line) in arid fore-summer of 1911.

FIG. 14.-Graphs showing altitudinal decrease in rate of evaporation in the Santa Catalinas on south-facing slopes (heavy line) and on north-facing slopes (light line) in humid mid-summer of 1911 .

is reversed at the higher elevations. In the humid season there is also a slightly greater rate of evaporation on the north slope at 4,000 feet, while all of the higher stations show an almost uniformly greater rate on the south slopes. It is impossible to explain the cases in which the evaporation was greater on north slopes than on south ones. It is possible, of course, that they require no explanation but are typical of the extremely arid conditions of the lowest elevations at the driest time of the year. They are at least accordant with the fact that the soil moisture is sometimes greater on the south slopes.

The summer averages show a difference of from 5 to 10 c.c. per day between the evaporation on opposed slopes, in readings of 35 to 45 c.c. per day or less. As the actual amounts of evaporation fall with increasing altitude, the difference between the opposed slopes becomes proportionately greater.

As in the case of all climatological data, it would be impossible to state the normal conditions of evaporation at the various altitudes 
and on opposed slopes without instrumental data for several series of stations and covering several years. It is possible, nevertheless, to state from the data presented that $(a)$ the rate of evaporation through the arid and humid summer seasons is about $31 / 2$ times as great on the desert as it is at 8,000 feet; $(b)$ the rates of evaporation are approximately half as great in the humid mid-summer as they are in the arid fore-summer; $(c)$ at the middle and higher altitudes the evaporation on north slopes is less than on south slopes; $(d)$ the difference between the amounts of evaporation on north and south slopes becomes greater with increase of altitude, in proportion to the amounts of each.

HUMIDITY.

The prevalence of low atmospheric humidities is one of the most pronounced features of desert climate and is an extremely potent factor in causing the high rates of evaporation that have been shown to occur at the lowest stations in the Santa Catalina Mountains. The relative humidity is lowest in the arid fore-summer, although it is sometimes nearly as low for brief periods in the arid after-summer. During the two rainy seasons the humidity is extremely variable and may fluctuate through a daily range of as much as 70 per cent. The daily curve of humidity is extremely uniform during the cloudless days of April, May, and June, falling rapidly during the early forenoon to mid-day values as low as 5 and 10 per cent, and rising slowly through the late afternoon and more rapidly during the night to a daily maximum of 20 to 30 per cent just before sunrise. Cloudy days in the arid seasons cause a higher minimum but seldom raise the maximum above 40 per cent unless there is a trace of rainfall.

The humidities of the mountain, varying with altitude and with the seasons, possess their greatest importance for vegetation in their rôle as joint determinants of the rate of evaporation. The altitudinal gradient of humidity has, therefore, been most satisfactorily investigated when it has been measured together with temperature and wind in the collective effect of these climatic factors upon the evaporative power of the air. It is not without interest, nevertheless, to know something of the relative humidities which are prevalent at the mountain altitudes and are partially responsible for the rates of evaporation encountered there.

In spite of the pronounced altitudinal changes of vegetation and of climatic conditions which have been discussed (or are yet to be treated), there are so many features of the Encinal and Forest vegetation that strongly suggest the Desert (see p. 36) that it seemed particularly desirable to secure readings of relative humidity at the forested altitudes in the arid fore-summer. The few figures to be given here were secured with a sling psychrometer and converted to percentages by the use of Marvin's tables. 
On May 22, 1911, in the east fork of Sabino Basin, at 3,400 feet elevation, the humidity at $3^{\mathrm{h}} 30^{\mathrm{m}} \mathrm{p}$. m. was 6 per cent, at $6 \mathrm{p} . \mathrm{m}$. it was 8 per cent, and at $8^{\mathrm{h}} 30^{\mathrm{m}}$ p. m. it was 12 per cent. At $4^{\mathrm{h}} 30^{\mathrm{m}}$ a. m., on the following day, the humidity had risen to 24 per cent. These figures show the prevalence of desert humidities at a locality which is low in elevation but is well in the heart of the mountain mass as a whole. At Marshall Gulch, at 7,600 feet in the Forest region, on May 20, 1911, the humidity at $11^{\mathrm{h}} 30^{\mathrm{m}}$ a. $\mathrm{m}$. was 10 per cent, and it was the same at $4^{\mathrm{h}} 30^{\mathrm{m}}$ p. m. At $9^{\mathrm{h}} 15^{\mathrm{m}}$ a. m. on the following day the humidity was 16 per cent, and at 3 p. m. it was 11 per cent. Although these figures are roughly twice those of the readings in Sabino Basin, they are nevertheless indicative of a low humidity for a forested locality and show that in the arid fore-summer there are days on which the humidity is nearly as low as it is on the Desert.

A number of humidity readings were taken in June 1911, but none of them showed as low values as those just mentioned. In Bear Cañon, at 6,100 feet elevation, on June 21 (a dull and intermittently cloudy day), the humidity was 46 per cent at $1 \mathrm{p}$. m. and 42 per cent at $3 \mathrm{p} . \mathrm{m}$., falling to 41 per cent at $7 \mathrm{p}$. m. In Marshall Gulch on June 23 (a nearly cloudless day), the humidity at $5 \mathrm{a} . \mathrm{m}$. was 33 per cent and it fell steadily to 22 per cent at 12 noon, with a temporary rise during an interval of cloudiness at $10 \mathrm{a} . \mathrm{m}$. In the afternoon the percentages rose from 25 per cent at $3 \mathrm{p}$. m. to 29 per cent at $6 \mathrm{p}$. m., but fell again to 26 per cent at $8 \mathrm{p} . \mathrm{m}$. The highest humidity observed at Marshall Gulch was 48 per cent at $4^{\mathrm{h}} 30^{\mathrm{m}} \mathrm{p}$. m. on June 8,1911 , after the summit of the mountain had been covered several hours with cumulus clouds.

Continuous records of relative humidity have been secured in yellow pine forest at the Fort Valley Experiment Station at 7,200 feet elevation, near Flagstaff, Arizona, by Pearson.* The monthly mean values for May and June (1909-1912) are 38 and 34.9 per cent respectively. Some of the lowest extremes involved in the composition of these means have been kindly communicated to the writer by Pearson. The number of days in June on which the humidity fell to 16 per cent or less was as follows: 8 days in 1909; 11 days in 1910; 6 days in 1911. The lowest humidities were a single occurrence of 10 per cent and two occurrences of 11 per cent. Humidities as low as 11 per cent also occur in July, and values as low as 16 per cent occur between May and October.

These figures for the Coconino Plateau are in agreement with the lowest figures secured at Marshall Gulch in May 1911, and show that desert humidities are of frequent occurrence in the arid fore-summer, both on isolated mountains, such as the Santa Catalinas, and on extended plateaus in the midst of the arid region. On the days that exhibit such low humidities at higher elevations there is practically a

* Pearson, G. A. A Meteorological Study of Parks and Timbered Areas in the Western Yellow Pine Forests of Arizona and New Mexico. Mo. Weather Rev., 41: 1615-1629, 1914. 
flat altitudinal gradient of humidity. The difference between the observed humidities of 6 per cent in Sabino Basin and 12 per cent at Marshall Gulch is a very small one, and would doubtless register very small differences on the rate of evaporation under otherwise identical conditions. The differences in evaporation actually found to exist between the base and summit of the mountain are to be ascribed to the nocturnal humidities, which are higher in the Forest than on the Desert, to the greater frequency of cloudiness at higher elevations in the arid fore-summer, to the lower temperatures at higher altitudes (especially at night), and to the wind protection afforded by the forest cover itself.

\section{TEMPERATURE.}

The investigation of temperature on the Santa Catalinas has been carried on with a view to determining the decrease in length of the frostless season which accompanies increase of altitude, the normal decrease of temperature with increasing altitude, and the departures from the normal gradient of decrease which are due to the nature of the topographic relief and to other causes. The results secured afford an outline of the major temperature features which are capable of influencing the distribution or seasonal activities of the plants of the Desert, Encinal, and Forest regions.

The character of the temperature conditions, and their relation to altitude and topography, in an isolated desert mountain is not without complexities which make it impossible to predict the conditions for vegetation in a given locality through a knowledge of its altitude and of general meteorological theory. The relative smallness of the entire mountain mass and its position in the midst of arid plains make its temperature conditions very different from those of extensive plateaus of the same elevation. The currents of warm air which ascend by day and the streams of cold air which descend by night serve to increase the diurnal amplitude of temperature in certain situations and to give striking differences within very short distances. Differences of slope exposure bring about differences of diurnal warming and nocturnal cooling of the soil, and these differences affect the general temperature conditions and also directly influence the vegetation. The differences of diurnal warming and nocturnal cooling which exist between the relatively bare soils of the Desert and Encinal regions and those of the Forest, with their heavy cover of vegetation, their litter of leaves and high humus content, are also considerable and tend to lessen the importance of topography at the higher elevations.

Temperature readings have been secured at two localities, at elevations of 5,300 and 7,600 feet, respectively, since the early summer of 1908. Since 1911 a series of thermometers has been exposed at the rainfall situations at 4,000,6,000, and 7,000 feet, and during 1913 and 1914 a complete series of thermometers was maintained at 1,000-foot 
intervals from 4,000 to 9,000 feet. All of the instruments in this series were located on the summits of ridges, so as to give comparable readings from similar topographic situations. In addition to the six instruments in this series there were also thermometers in the bottoms of cañons at $5,000,6,000$, and 7,600 feet; a thermometer was exposed on the top of the fire tower of the Forest Service on Mount Lemmon, the actual elevation of the instrument being 9,225 feet, and thermometers were buried in the topmost layer of soil at 6,000 and 8,000 feet.

Alcoholic minimum thermometers were used in the earlier years of these observations, but were replaced by mercuric Six's thermometers in 1913 and 1914. Various types of thermometer have been used at the station at 7,600 feet, and as many as three instruments have been exposed simultaneously at that place. All thermometers have been calibrated before use and have been verified in place from time to time by comparison with a portable thermometer of known error. The readings of the thermometers have been taken at irregular intervals, as opportunity afforded, and most of the figures secured are for periods of several weeks, or for the several months which elapse between the last visit in the autumn and the first in the spring. Only at the 7,600and 9,000-foot stations has it been possible to expose the thermometers in such a manner as to secure reliable maxima; at all other stations the only data secured have been the absolute minima for the intervals between visits. The placing of the thermometers in small boxes, with numerous perforations, has made possible the securing of good minima, but no record has been made of the maxima secured under such conditions of exposure. The conspicuousness of adequate instrument shelters would have invited human interference with the thermometers which would have been productive of errors.

A few records of temperature from the same locality for a number of consecutive days have been secured by Professor J. G. Brown and by Dr. H. A. Spoehr, as well as by the writer. A large number of single observations of minima and of current temperatures have been made by the writer at various localities, and it has been possible to use these in connection with data from the regular stations in determining the normal gradient of temperature decrease and in ascertaining the vertical shortening of the frostless season.

\section{LENGTH OF FROSTLESS SEASON.}

It has been impossible, for the most part, to make direct observations of the dates of last vernal and first autumnal occurrence of a temperature of $32^{\circ} \mathrm{F}$. at the several stations on the Santa Catalinas. The dates at which visits were made to the mountain were occasionally such as to establish the dates exactly for one of the stations, and in several cases visits were made at such frequent intervals as to place the date within a week or two. In the majority of cases, however, 
the frost dates which limited the growing season fell between the last visit of autumn and the first one of spring. This has particularly been the case with all of the lower stations. These circumstances have made it necessary to resort to an indirect method of determining the dates, which is as follows: A series of graphs was drawn showing the march of the weekly absolute minimum temperatures at the Desert Laboratory, as registered by thermograph, for the years covered by the mountain records. Each reading of minimum temperature for a given station was then compared with the minimum for the same period at the Desert Laboratory, and the total number of such differences was averaged. In this manner it was possible to secure the figures given in tables 10 and 11.

TABLE 10.-Altitudinal shortening of the frostless season in the Santa Catalina Mountains, as shown by the dates of the last spring occurrence and the first autumn occurrence of a temperature of $32^{\circ}$ at 3 altitudes in 1908, 1909, and 1910.

\begin{tabular}{|c|c|c|c|}
\hline Station, etc. & Year. & $\begin{array}{l}\text { Last } 32^{\circ} \\
\text { in spring. }\end{array}$ & $\begin{array}{c}\text { First } 32^{\circ} \\
\text { in autumn. }\end{array}$ \\
\hline $\begin{array}{l}\text { Desert Laboratory; elevation, } 2,663 \\
\text { feet; length of frostless season, } 285 \\
\text { days. }\end{array}$ & $\left\{\begin{array}{l}1908 \\
1909 \\
1910\end{array}\right.$ & $\begin{array}{l}\text { Feb. } 20 \\
\text { Mar. } 15 \\
\text { Feb. } 25\end{array}$ & $\begin{array}{l}\text { Nov. } 30 \\
\text { Nov. } 30 \\
\text { Dec. } 31\end{array}$ \\
\hline Average dates............... & … & Mar. 1 & Dec. 10 \\
\hline $\begin{array}{l}\text { Xero-Montane Garden; elevation, } \\
5,300 \text { feet; length of frostless season, } \\
195 \text { days. }\end{array}$ & $\left\{\begin{array}{l}1908 \\
1909 \\
1910\end{array}\right.$ & $\begin{array}{l}\text { May } 10 \\
\text { Apr. } 12 \\
\text { Apr. } 20\end{array}$ & $\begin{array}{l}\text { Oct. } 10 \\
\text { Nov. } 10 \\
\text { Nov. } 26\end{array}$ \\
\hline 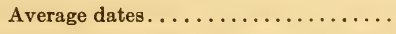 & $\cdots \cdots \cdots$ & Apr. 24 & Nov. 5 \\
\hline $\begin{array}{l}\text { Montane Garden, Marshall Gulch; } \\
\text { elevation, 7,600 feet; length of frost- } \\
\text { less season, } 126 \text { days. }\end{array}$ & $\left\{\begin{array}{l}1908 \\
1909 \\
1910\end{array}\right.$ & $\begin{array}{l}\text { June } 15 \\
\text { May } 31 \\
\text { May } 9\end{array}$ & $\begin{array}{l}\text { Sept. } 25 \\
\text { Sept. } 26 \\
\text { Oct. } 17 \text { (?) }\end{array}$ \\
\hline Average dates... & & May 29 & Oct. \\
\hline
\end{tabular}

With a knowledge of the average difference between the minimum temperature at the Desert Laboratory and at a given station, and with the graph showing the march of minima at the Laboratory, it was possible to locate the approximate date of the last and first occurrence of $32^{\circ}$ at the mountain station. Such a graph for 1911 is given in figure 17, together with the graph of march of minimum temperatures at the Montane Plantation in Marshall Gulch, at 7,600 feet. It will be noted that the graph for the Laboratory rises by several pronounced jumps during March, April, and May, and falls by precipitate stages during September, October, and November. The relatively sudden advent of summer and of winter is an invariable annual occurrence, and it has helped to make more accurate the estimation of the limiting dates for the mountain stations. In the cases in which a minimum 
temperature of $32^{\circ}$ or less was registered at a station during an interval of two or three weeks, the date of such minimum could be determined by finding the exact date of the lowest temperature for the same period at the Desert Laboratory, and such determinations undoubtedly have a very slight possibility of error. Taking into account the number of direct observations and the larger number of estimations, the limiting dates of the frostless season, given in tables 10 and 11, may contain errors of as much as 7 to 10 days. The swamping of these errors by averaging the dates for the 6 years of observation reduces the probable error to about 5 days.

TABLE 11.-The altitudinal shortening of the frostless season in the Santa Catalina Mountains, as shown by the dates of the last spring occurrence and the first autumn occurrence of a temperature of $32^{\circ}$ at 5 altitudes in 1911, 1912, and 1913.

[Data for 9,000 feet are partially interpolated.]

\begin{tabular}{|c|c|c|c|}
\hline Station. & Year. & $\begin{array}{l}\text { Last } 32^{\circ} \\
\text { in spring. }\end{array}$ & $\begin{array}{l}\text { First } 32^{\circ} \\
\text { in autumn. }\end{array}$ \\
\hline $\begin{array}{l}\text { Desert Laboratory; elevation, } 2,663 \\
\text { feet; length of frostless season, } 282 \\
\text { days. }\end{array}$ & $\left\{\begin{array}{l}1911 \\
1912 \\
1913\end{array}\right.$ & $\begin{array}{l}\text { Feb. } 20 \\
\text { Feb. } 26 \\
\text { Mar. } 31\end{array}$ & $\begin{array}{l}\text { Dec. } 25 \\
\text { Dec. } 9 \\
\text { Dec. } 8\end{array}$ \\
\hline Average dates...................... & ....... & Mar. 7 & Dec. 14 \\
\hline $\begin{array}{l}\text { Climatological Station; elevation, } 5,000 \\
\text { feet; length of frostless season, } 248 \\
\text { days. }\end{array}$ & $\left\{\begin{array}{l}1911 \\
1912 \\
1913\end{array}\right.$ & $\begin{array}{l}\text { Feb. } 27 \\
\text { Apr. } 15 \\
\text { Apr. } 14\end{array}$ & $\begin{array}{l}\text { Dec. } 4 \\
\text { Dec. } 9 \\
\text { Nov. } 21\end{array}$ \\
\hline Average dates.................... & ......... & Mar. 30 & Dec. 1 \\
\hline $\begin{array}{l}\text { Climatological Station; elevation, } 7,000 \\
\text { feet; length of frostless season, } 187 \\
\text { days. }\end{array}$ & $\left\{\begin{array}{l}1911 \\
1912 \\
1913\end{array}\right.$ & $\begin{array}{l}\text { Apr. } 3 \\
\text { May } 13 \\
\text { May } 5\end{array}$ & $\begin{array}{l}\text { Oct. } 30 \\
\text { Nov. } 18 \\
\text { Oct. } 13\end{array}$ \\
\hline Average dates.................... & ....... & Apr. 27 & Oct. 31 \\
\hline $\begin{array}{l}\text { Marshall Gulch; elevation, } 7,600 \text { feet; } \\
\text { length of frostless season, } 148 \text { days. }\end{array}$ & $\left\{\begin{array}{l}1911 \\
1912 \\
1913\end{array}\right.$ & $\begin{array}{l}\text { May } 16 \\
\text { May } 18 \\
\text { May } 9\end{array}$ & $\begin{array}{l}\text { Oct. } 30 \\
\text { Oct. } 2 \\
\text { Sept. } 26\end{array}$ \\
\hline Average dates................... & ….... & May 14 & Oct. 9 \\
\hline $\begin{array}{l}\text { Mount Lemmon; elevation, } 9,000 \text { feet; } \\
\text { length of frostless season, } 122 \text { days. }\end{array}$ & $\left\{\begin{array}{l}1911 \\
1912 \\
1913\end{array}\right.$ & $\begin{array}{l}\text { May } 29 \\
\text { May } 20 \\
\text { June } 16\end{array}$ & $\begin{array}{l}\text { Oct. } 16 \\
\text { Oct. } 7 \\
\text { Sept. } 8\end{array}$ \\
\hline Average dates............... & 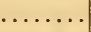 & June 1 & Sept. 30 \\
\hline
\end{tabular}

In figure 2 are shown separately the curves for altitudinal shortening of the frostless season for the years 1908, 1909, and 1910, and the years 1911,1912 , and 1913. In the latter group of years the advent of spring was nearly a month earlier at the middle altitudes than it was during the former years, and the advent of winter was correspondingly later, in spite of the fact that the frostless season was of approximately the same length at the Desert Laboratory during the two periods. A con- 
sideration of the two sets of curves is more fruitful than the possession of their average, as it shows the extent of a fluctuation which must be a common and normal feature of the climatology of the mountain, just as it is of every locality, regardless of its topographic location.

The average length of the frostless season at the Desert Laboratory is about 38 weeks, at 5,000 feet in the Santa Catalinas it is about 30 weeks, while at 8,000 feet it is about 17 weeks. The period of safe plant activity is, therefore, less than half as long in the Forest region of the mountain as it is in the Desert of the Santa Cruz Valley. The altitudinal abbreviation of the frostless season is of primary importance to vegetation, especially as it is accompanied by a series of inseparable features of temperature, such as the lower range of the entire daily curve of temperature, the attainment of lower minima, the more

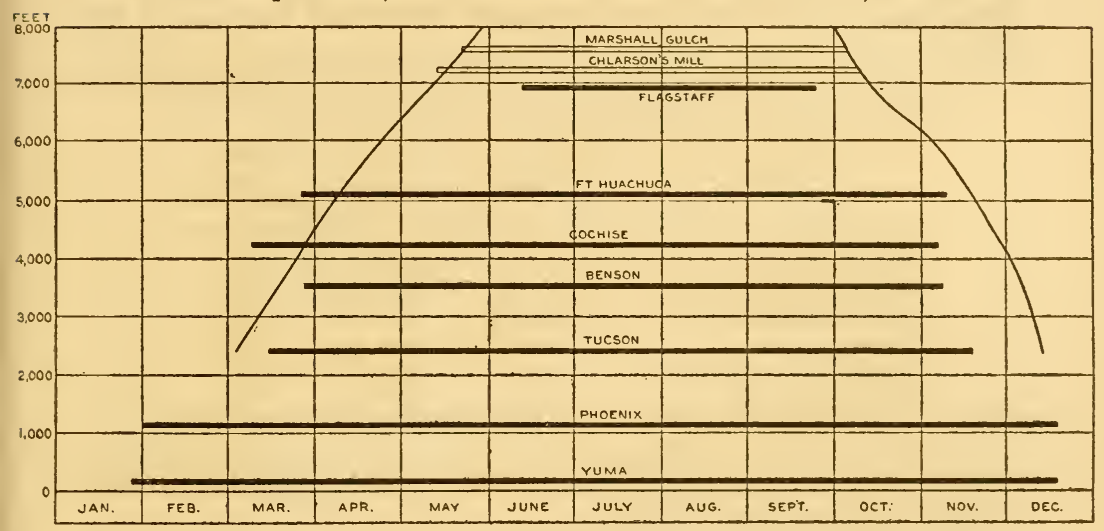

Fig. 15.-Schematic representation of length of frostless season at different altitudes in Arizona, together with curves for limits of growing season at successive altitudes in the Santa Catalinas for 1909 to 1914 inclusive.

frequent occurrence, and the longer duration of freezing temperatures. One of the cardinal features of importance in the altitudinal shortening of the growing season is the concomitant shortening of the arid foresummer. The rising temperatures of spring call the vegetation of the Desert into activity at a time of the year when extremely arid conditions are bound to prevail for from 14 to 16 weeks. At the summit of the mountain, however, the advent of spring is only 5 or 6 weeks in advance of the earliest of the mid-summer rains. In other words, the most trying season of the year is shortened on the mountain by the inhibitory effects of low temperatures, so that the arid fore-summer is only one-third as long in the Forest as in the Desert. These relations are graphically represented in figure 2 , which shows both the curves of the frost dates and the incidence of the rainy seasons. More will be said in regard to this subject in a succeeding section (see p. 93). 
In order to compare the altitudinal shortening of the frostless season on the Santa Catalinas with the same datum for a series of valley stations located at progressive altitudes, figures were collected which are shown in table 12. These figures are based on the last vernal and first autumnal occurrence of a temperature of $32^{\circ}$, for 1903 to 1912 inclusive, without regard to the reports of frost made by the voluntary observers at these stations. In figure 15 the length of the frostless season at the several stations is graphically shown by horizontal lines, and the limits of the frostless season for the Santa Catalinas (for 1909 to 1914) are shown by oblique lines.

Spring opens at an earlier date at 3,000 and 4,000 feet on the Santa Catalinas than it does at Tucson and Benson, but at 4,000 and 5,000 feet it does not open at so early a date as it does at Cochise and Fort Huachuca. At all four of the elevations mentioned the close of the

TABLE 12.-The altitudinal shortening of the frostless season in southeastern Arizona, as shown by the dates of the last spring occurrence and the first autumn occurrence of a temperature of $32^{\circ}$ at eight stations at graduated altitudes, in the decade of 1903 to 1912.

\begin{tabular}{|c|c|c|c|}
\hline Station. & $\begin{array}{l}\text { Last } 32^{\circ} \\
\text { in spring. }\end{array}$ & $\begin{array}{l}\text { First } 32^{\circ} \\
\text { in autumn. }\end{array}$ & $\begin{array}{c}\text { Length of } \\
\text { frostless } \\
\text { season (days). }\end{array}$ \\
\hline Yuma, 141 feet............. & Jan. 28 & Dec. 18 & 325 \\
\hline Phœenix, 1,108 feet...... & Feb. 1 & Dec. 18 & 321 \\
\hline Tucson, 2,390 feet. . . . . . . . . & Mar. 15 & Nov. 19 & 248 \\
\hline Benson, 3,523 feet. . . . . . . . . & Mar. 26 & Nov. 7 & 226 \\
\hline Cochise, 4,219 feet. . . . . . . . & Mar. 10 & Nov. 6 & 241 \\
\hline Fort Huachuca, 5,100 feet...... & Mar. 26 & Nov. 8 & 227 \\
\hline Flagstaff, 6,907 feet. . . . . . & June 11 & Sept. 24 & 105 \\
\hline Chlarson's Mill, 7,200 feet *.... & May $13 \dagger$ & Oct. $19 \dagger$ & 159 \\
\hline
\end{tabular}

* The elevation of Chlarson's Mill is reputed by the proprietor to be $8,000 \mathrm{feet}$, and it is so stated in the publications of the Weather Bureau. Several aneroid determinations by the writer indicate that it is approximately 7,200 feet.

$\uparrow$ These dates are based on an incomplete record.

growing season comes sooner at the valley stations than it does on the mountains. The length of the frostless season at Flagstaff is notably shorter than it is at the same elevation in the mountains.

The advent of spring is retarded at Tucson and Benson by the coldair drainage of the Santa Cruz and San Pedro rivers respectively. Cochise is situated in the middle of the eastern bajada of the Dragoon Mountains and Fort Huachuca at the top of the northern bajada of the Huachuca Mountains. Each of these stations is therefore removed from the operation of cold-air drainage, as is manifested by the failure of their greater altitude to impose upon them shorter frostless seasons than those of Tucson and Benson.

The length of the frostless season at Marshall Gulch and at the similarly situated mountain station at Chlarson's Mill (Pinaleno Mountains) is greater than at Flagstaff, which is at a slightly lower altitude. This is to be attributed partly to the higher latitude of Flagstaff, but 
chiefly to its location on an extensive elevated plateau and to its proximity to the cold-air flow from the San Francisco Peaks and other neighboring elevations.

It may be said, in general, that the frostless season is longer on the ridges of an isolated mountain than it is in adjacent valleys at the same elevations. Although the advent of spring at Cochise and Fort Huachuca is earlier than on the mountains, the arrival of autumn is earlier also, so that these two stations show an equality in length of frostless season with the mountain ridges without a correspondence with them in the dates of commencement and close.

\section{NORMAL ALTITUDINAL TEMPERATURE GRADIENT.}

The temperatures which have been secured on the Santa Catalinas do not form an altogether satisfactory basis for the determination of

TABLE 13.-Average differences between all observed minimum temperatures at stations siluated on ridges in the Santa Catalina Mountains and the minima for the same days or periods at the Desert Laboratory.

\begin{tabular}{|c|c|c|c|c|c|}
\hline Station. & 1911. & 1912. & 1913. & 1914. & Average. \\
\hline 4,000 feet... & +7.2 & & +.1 & 1.6 & +1.9 \\
\hline 5,000 feet... & & & & 8.1 & 8.1 \\
\hline 6,000 feet... & 12.5 & & 7.5 & 7.6 & 9.2 \\
\hline 7,000 feet... & 16.1 & & 11.1 & 14.0 & 13.7 \\
\hline 8,000 feet... & & & ........ & 20.1 & 20.1 \\
\hline 9,000 feet... & & 31.1 & & 20.8 & 25.9 \\
\hline
\end{tabular}

[The plus sign indicates a higher temperature at the mountain station.]

the normal altitudinal gradient, a datum which should be derived from extended series of mean temperatures. However, in the absence of an ideal collection of records from the several altitudes these imperfect

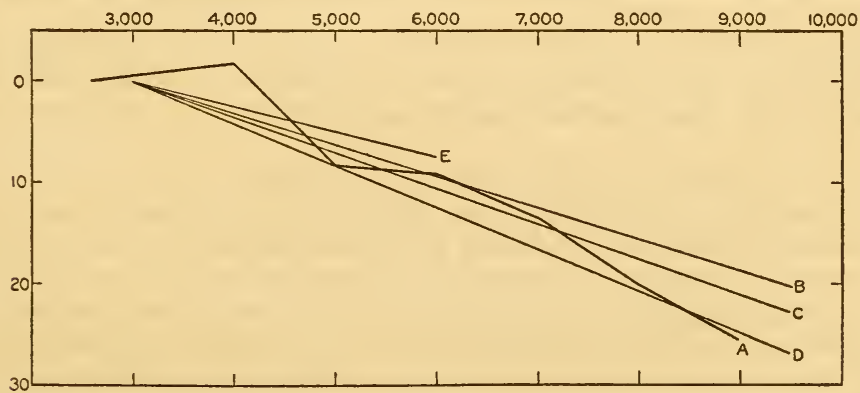

Frg. 16.-Graph showing altitudinal fall in temperature in the Santa Catalina Mountains (A), and lines showing rate of fall in free air (E) on Pike's Peak (C), on the Sierra Nevada (D), and average rate for 17 extra-tropical mountains (B).

data have been used as the basis of an approximate determination of the gradient of fall of temperature with increase of altitude. The 
minimum temperatures at the several stations are the only ones that have been used, and they have been in all cases compared with the minimum for the same period at the Desert Laboratory. The average differences between the minima of the mountain stations and those of the Laboratory are shown in table 13 , and it is these differences that

TABLE 14.-Daily maximum and minimum temperatures at Marshall Gulch (7,600 feet) and at the Desert Laboratory for June, July, and August 1911.

\begin{tabular}{|c|c|c|c|c|c|c|c|c|c|c|c|c|}
\hline \multirow{3}{*}{$\begin{array}{c}\text { Day } \\
\text { of } \\
\text { month. }\end{array}$} & \multicolumn{4}{|c|}{ June. } & \multicolumn{4}{|c|}{ July. } & \multicolumn{4}{|c|}{ August. } \\
\hline & \multicolumn{2}{|c|}{ Minima. } & \multicolumn{2}{|c|}{ Maxima. } & \multicolumn{2}{|c|}{ Minima. } & \multicolumn{2}{|c|}{ Maxima. } & \multicolumn{2}{|c|}{ Minima. } & \multicolumn{2}{|c|}{ Maxima. } \\
\hline & M. G. & D. L. & M. G. & D. L. & M. G. & D. L. & M. G. & D. L. & M. G. & D. L. & M. G. & D. L. \\
\hline 1st. . & & & & & & 65 & & 81 & 51 & 76 & 81 & \\
\hline & $\cdots$ & . & & & 48 & 65 & 74 & 83 & 52 & 81 & 77 & \\
\hline $3 \mathrm{~d} .$. & ... & ... & .... & ....... & 46 & 69 & 64 & 95 & 48 & 77 & 80 & 106 \\
\hline 4th..... & $\cdots$ & $\cdots \cdots$ & $\cdots \cdots$ & $\ldots \ldots$ & $\ldots \ldots$ & 73 & 70 & 100 & 45 & 76 & 83 & 103 \\
\hline 5th..... & 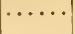 & d & $\ldots \ldots$ & $\ldots \ldots$ & $\cdots \cdots$ & 78 & 67 & 103 & 48 & 74 & 81 & $\ldots \ldots$ \\
\hline 6th. . & • & & & & 46 & 80 & 67 & 98 & & & & 103 \\
\hline 7 th.... & & & & & 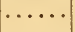 & & .... & ...... & 48 & 80 & 84 & ...... \\
\hline 8th..... & 48 & 75 & 77 & 106 & & & $\cdots$ & $\ldots \ldots$ & 50 & 80 & 74 & \\
\hline 9 th...... & 48 & 76 & & 103 & $\cdots$ & 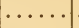 & $\ldots \ldots$ & $\ldots \ldots$ & 48 & 74 & 78 & 91 \\
\hline 10 th..... & 44 & 73 & 79 & 104 & . & -3 & $\ldots \ldots$ & $\cdots \cdots$ & 50 & 76 & 74 & 94 \\
\hline 11 th. & 46 & 76 & 67 & 97 & 52 & 73 & 62 & 92 & 48 & 77 & 73 & 89 \\
\hline 12th. & 48 & 73 & 66 & 96 & 49 & 73 & 73 & 98 & 50 & 79 & 70 & 102 \\
\hline 13th. . & 49 & 77 & 59 & 85 & $\ldots \ldots$ & ..... & $\cdots \cdots$ & ...... & 50 & 78 & 75 & 105 \\
\hline 14th..... & 41 & 74 & 70 & 98 & ...... & & ...... & ...... & 49 & 76 & 76 & 107 \\
\hline 15 th..... & 41 & 74 & 74 & 97 & $\cdots \cdots$ & $\ldots \ldots$ & $\cdots \cdots$ & ...... & 54 & 81 & 81 & 110 \\
\hline 16th. & 41 & 70 & 76 & 98 & 52 & 80 & 73 & 102 & 52 & 82 & 74 & 109 \\
\hline 17 th... & & 69 & & 102 & 51 & 71 & 65 & 92 & 52 & 73 & 71 & 107 \\
\hline 18 th..... & 39 & 71 & 79 & 106 & & & 63 & 95 & 49 & 73 & 74 & 105 \\
\hline 19th..... & 40 & 81 & 74 & 101 & 54 & 76 & 64 & 97 & 50 & 79 & 76 & 107 \\
\hline 20 th..... & 41 & 73 & 72 & 99 & 52 & 79 & 64 & 94 & 49 & 71 & 75 & 100 \\
\hline 21st & 41 & 75 & 81 & 106 & 52 & 74 & 65 & 94 & 52 & 68 & 63 & 88 \\
\hline & 41 & 78 & 81 & 104 & 48 & 71 & 70 & 99 & 51 & 69 & 61 & 93 \\
\hline $23 \mathrm{~d} . .$. & 40 & 73 & 83 & 104 & 49 & 76 & 66 & 101 & 46 & 67 & 62 & 94 \\
\hline 24th..... & 46 & 76 & 83 & 106 & 50 & 78 & 63 & 100 & 48 & 74 & ...... & $\ldots \ldots$ \\
\hline 25 th..... & 49 & 73 & 85 & 105 & 49 & 76 & 65 & 94 & $\cdots \cdots$ & $\cdots \cdots$ & $\cdots \cdots$ & (n) \\
\hline 26th & 43 & 73 & 85 & 108 & 53 & 78 & 61 & 96 & & & & ... \\
\hline 27 th..... & 48 & 75 & 84 & 108 & 47 & 67 & 67 & 89 & .. & $\cdots$ & ..... & ..... \\
\hline 28 th..... & 52 & 78 & 84 & 108 & 53 & 72 & 73 & & $\cdots$ & & ..... & .... \\
\hline 29th..... & 46 & 78 & 76 & 100 & 53 & 76 & 67 & 100 & t & $\cdots$ & … & … \\
\hline 30 th..... & $\ldots \ldots$ & 74 & $\ldots \ldots$ & 86 & 52 & 78 & 78 & 104 & $\cdots \cdots$ & ..... & ....... & \\
\hline 31st..... & & & & & 50 & 77 & 82 & ....... & ....... & 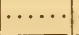 & & 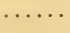 \\
\hline $\left.\begin{array}{l}\text { Average } \\
\text { difference }\end{array}\right\}$ & 21 day & $\mathrm{s}, 30.5^{\circ}$ & 20 day & $7 \mathrm{~s}, 25.0^{\circ}$ & 20 day & $\mathrm{s}, 24.1^{\circ}$ & 21 day & $\mathrm{s}, 29.4^{\circ}$ & 23 day & $\mathrm{s}, 26.1^{\circ}$ & 17 day's & $\mathrm{s}, 27.3^{\circ}$ \\
\hline
\end{tabular}

have been used in the construction of the graph in figure 16, which shows the gradient for the Santa Catalinas, the average gradient for 17 mountain ranges in different portions of the world (according to Hann), the gradient for Pike's Peak, the Sierra Nevada, and also the gradient in the free air, as determined at the Blue Hill Observatory. 
Some estimate of the error involved in basing the gradient only on minimum readings may be made by the figures presented in tables 14 and 15 . These tables exhibit the only daily records of maximum and minimum temperatures for the Catalinas for any period longer than a few days. The average maxima and minima for Marshall Gulch for the months of June, July, and August have been contrasted in table 14, with the average maxima and minima for the Laboratory. During June the apartness of the minima was $30.5^{\circ}$, of the maxima $25.0^{\circ}$. In July this relation was reversed, the apartness of the minima being $24.1^{\circ}$, that of the maxima $29.4^{\circ}$, while for August the two were more nearly the same, the apartness of maxima being $26.1^{\circ}$, of maxima $27.3^{\circ}$. The facts that the minimum temperatures of valley and mountain were further apart than the maxima were during June, and not so far apart in July and August, may be connected in some manner with the clear dry weather of June and the rainy, cloudy character of July and August. However, the data in table 15, showing the maximum

TABLE 15.-Daily record of maximum and minimum temperatures for a portion of June 1912, at summit of Mount Lemmon, with corresponding data for the Desert Laboratory.

\begin{tabular}{|c|c|c|c|c|c|c|c|c|c|c|}
\hline \multirow{2}{*}{\multicolumn{2}{|c|}{ Day of month. }} & \multicolumn{2}{|c|}{ Minimum. } & \multicolumn{2}{|c|}{ Maximum. } & \multirow{2}{*}{ Day of month. } & \multicolumn{2}{|c|}{ Minimum. } & \multicolumn{2}{|c|}{ Maximum. } \\
\hline & & M. L. & D. L. & M. L. & D. L. & & M. L. & D. L. & M.L. & D. L. \\
\hline \multirow{7}{*}{ June } & & ${ }^{\circ} \mathrm{F}$. & ${ }^{\circ} \mathrm{F}$. & ${ }^{\circ} \mathrm{F}$. & $\circ \mathrm{F}$. & & ${ }^{\circ} \mathrm{F}$. & ${ }^{\circ} \mathrm{F}$. & ${ }^{\circ} \mathrm{F}$. & - F. \\
\hline & 7. & 46 & & 73 & $\ldots \ldots$ & June 13 . & 43 & 74 & 68 & 101 \\
\hline & & 46 & ...... & 77 & $\ldots \ldots$ & 14 & 43.5 & 71 & 66 & 104 \\
\hline & 9. & 45 & & 72 & $\ldots \ldots$ & 15. & 45 & 76 & 69 & 105 \\
\hline & $10 \ldots \ldots$ & 40.5 & & 67 & 102 & 16. & 44 & 78 & 71 & 102 \\
\hline & & 42 & 70 & 69 & 101 & & 41 & 77 & 70 & 102 \\
\hline & & 41.5 & 71 & 69.5 & 100 & $18 \ldots \ldots$ & 41 & 72 & 69 & 106 \\
\hline
\end{tabular}

Average difference of maxima, 33.9; of minima, 31.1.

and minimum temperatures on Mount Lemmon in June 1912, indicate that there was a greater apartness of maxima than of minima when these data are averaged and contrasted with those for the Desert Laboratory.

It would require a much fuller mass of figures than are in hand to make any attempt at an explanation of the differences that exist in the apartness of desert and mountain maxima and minima in different localities and different months. For the present purpose it is instructive to average the entire set of apartnesses for Marshall Gulch for June, July, and August 1911, which gives an average difference of minima of $80.7^{\circ}$, and of maxima of $81.7^{\circ}$. In other words, throughout a series of several months there is doubtless a swamping of the irregularity of the apartnesses for individual months. If, then, there is an average equality between the apartness of maxima and minima-which is to say that there is an equality of daily mean range of temperature between desert and mountain-it would indicate that the minima are 
just as good data on which to base an estimation of the gradient as mean temperatures would be. Since the figures used in constructing the gradient were secured in all months from April to October, in several years, and in a wide diversity of localities-all outside the influence of cold-air drainage - it is probable that the gradient here presented, figure 16, is within one or two degrees of the same measure of accuracy that could be secured by a long series of consecutive readings of maximum and minimum.

Using the elevation of the Desert Laboratory (2,663 feet) as a base, the actual fall of temperature between that locality and the 9,000-foot station on the Santa Catalinas is at the rate of $4.11^{\circ}$ per 1,000 feet. The gradients between the several mountain stations are indicated in

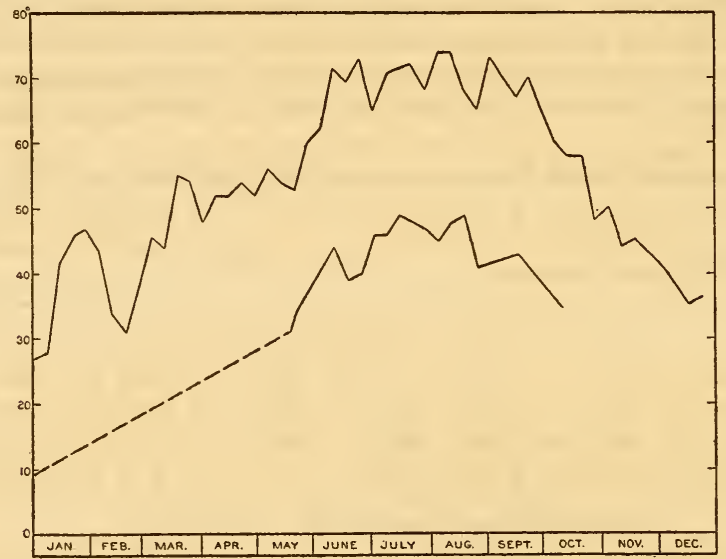

Frg. 17.-Graphs showing march of weekly minimum temperature at Desert Laboratory (upper) and weekly or other minimum temperature at Marshall Gulch for 1911 (lower).

figure 16, on which it will be seen that there is a negative gradient between the Desert Laboratory and the 4,000-foot station, and that the gradient between 4,000 and 5,000 feet is at the rate of $10^{\circ}$ per 1,000 feet. From 5,000 feet upward the gradients are more uniform and more nearly equal between the successive stations.

Figures are given by Hann * for the gradients of temperature on a number of mountains in different parts of the world. The average values for 17 extra-tropical mountains is $3.13^{\circ} \mathrm{F}$. per 1,000 feet $\left(0.57^{\circ} \mathrm{C}\right.$. per $100 \mathrm{~m}$.). The only mountains in the western United States for which Hann gives figures are Pike's Peak and Sierra Nevada (Colfax, Placer County). The gradient of the former is $3.46^{\circ}$ per 1,000 feet

* Hann, J. Handbook of Climatology. Translation by R. DeC. Ward, pp., 243-246. New York, 1903. 
$\left(0.63^{\circ} \mathrm{C}\right.$. per $100 \mathrm{~m}$.), and for the latter $4.12^{\circ}$ per 1,000 feet $\left(0.75^{\circ} \mathrm{C}\right.$. per $100 \mathrm{~m}$.). The gradient for Colfax is seen to be almost exactly coincident with the entire gradient for the Santa Catalinas. It is interesting to note, in this connection, that the fall of temperature in the free air has been determined at the Blue Hill Observatory to be $2.5^{\circ} \mathrm{F}$. per 1,000 feet, which is far more gradual than any of the mountain gradients that have been cited. The Blue Hill data apply only to low elevations, but are in substantial agreement with figures more recently secured in the free air at Avalon, California.* Seven balloon ascensions from Avalon to elevations of $18 \mathrm{~km}$. and higher showed a mean gradient of fall in the first $3 \mathrm{~km}$. $\left(9,842 \mathrm{ft}\right.$.) of $2 \cdot 2^{\circ}$ per 1,000 feet. These two determinations of the free-air gradient indicate a conservatism of temperature change in the lower atmosphere as compared with the changes on the slopes of mountains.

While the normal temperature gradient is of profound interest from the standpoint of pure climatology, it is nevertheless of subsidiary value in the study of climate in relation to vegetation. Its chief value is as a basis with which to compare the differentiation of temperature conditions originating in the irregularities of topography and other causes. In later pages the subsidiary influences upon the temperature gradient will be discussed.

\section{THE ABSOLUTE MINIMUM OF WINTER.}

The absolute minimum temperature of the winter was secured at 5,300 feet and at 7,600 feet for four winters, and during the winter of 1912 and 1913 was secured at four stations, and during the succeeding winter at 10 stations, differing both in altitude and in topographic location.

The winter of 1912 and 1913 was one of exceptional severity at Tucson-in fact throughout the extreme southwestern United Stateswhile the winter of 1913 and 1914 was one of the customary moderation. The data for these two winters are calculated, therefore, to exhibit the extreme and the average conditions of winter temperature for stations in Arizona.

The minimum temperature readings at the mountain stations are given in table 16; and in table 17 are given the minima for December, January, and February of the same years for a selected series of stations in Arizona. The lowest temperature recorded on the Santa Catalinas in 1912-13 was $-6^{\circ}$ at 6,000 feet, while the lowest temperature at the highest station, at 7,600 feet, was $-2^{\circ}$. This figure should be contrasted both with the absolute minimum at the Arizona Experiment Station, $6^{\circ}$, and with that at the office of the Desert Laboratory, $1^{\circ}$, as well as with that for Flagstaff, $-23^{\circ}$, situated in northern central

\footnotetext{
* Blair, William R. Free-Air Data in Southern California, July and August, 1913. Mo. Weather Rev., 42: 410-426, 1914.
} 
Arizona at an elevation 700 feet lower than that of the 7,600-foot Station in Marshall Gulch. The extremely low temperatures at the Arizona Experiment Station and the office of the Desert Laboratory, as contrasted with the minimum temperature of $17^{\circ}$ at the Desert

TABLE 16.-Absolute minimum temperatures of two winters at stations in the Santa Catalina Mountains and at Tucson.

\begin{tabular}{|c|c|c|c|}
\hline Station. & Location of station. & $1912-1913$. & 1913-1914 \\
\hline 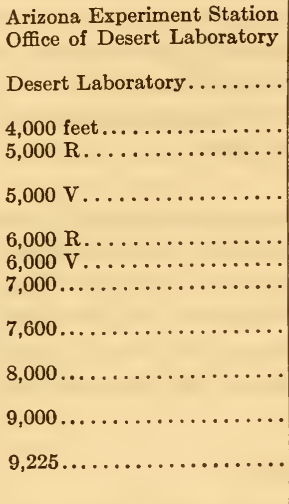 & 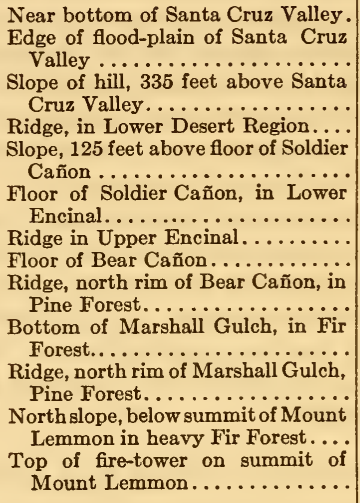 & $\begin{array}{c}-6 \\
\ldots \\
.5\end{array}$ & $\begin{array}{r}29 \\
27 \\
18 \\
18 \\
18 \\
6 \\
12\end{array}$ \\
\hline
\end{tabular}

Laboratory, are to be accounted for through the operation of cold-air drainage. On the coldest night in January 1913 there was a difference of only $3^{\circ}$ between the temperatures of the Santa Cruz Valley and Marshall Gulch, 5,400 vertical feet apart. It is desired here not so

TABLE 17.-Absolute minimum temperatures of winter months for two winters at selected stations in Arizona, together with the absolute winter minima at 7,600 feet in the Santa Catalina Mountains.

\begin{tabular}{|c|c|c|c|c|c|c|}
\hline \multirow{2}{*}{ Station. } & \multicolumn{3}{|c|}{ 1912-1913. } & \multicolumn{3}{|c|}{ 1913-1914. } \\
\hline & Dec. & Jan. & Feb. & Dec. & Jan. & Feb. \\
\hline Santa Catalinas, 7,600 feet. . & & -2 & & & 15.5 & \\
\hline Tucson, 2,390 feet. $\ldots \ldots \ldots \ldots \ldots \ldots \ldots \ldots \ldots$ & 18 & 6 & 28 & 28 & 26 & 26 \\
\hline Chlarson's Mill, 7,200 feet $\ldots \ldots \ldots \ldots \ldots \ldots \ldots \ldots$ & $\begin{array}{r}15 \\
0\end{array}$ & -23 & -7 & -5 & -1 & $\cdots \cdots$ \\
\hline Fort Valley Experiment Station, 7,300 feet....... & -7 & -27 & -14 & -17 & -13 & -4 \\
\hline Fort Apache, 5,200 feet..................... & -2 & -5 & 5 & 3 & -1 & 14 \\
\hline Fort Huachuca, 5,100 feet............. & 21 & 1 & 21 & 26 & 23 & 29 \\
\hline Snowflake, 5,644 feet............. & -4 & -8 & -11 & 10 & 7 & 9 \\
\hline
\end{tabular}

much to lay emphasis on the exceptional coldness of the Santa Cruz valley, but on the exceptional warmness of the summit of the Santa Catalinas, as contrasted with similar elevations in Arizona which are 
very dissimilar in their topographic location. In table 17 it will be seen that the winter minimum at Flagstaff, in northern central Arizona, was $21^{\circ}$ below the minimum for Marshall Gulch, although Flagstaff is located 700 feet lower. This relation is similar to that which exists between the length of frostless season at Marshall Gulch and at Flagstaff, and is due to the facts mentioned in that connection on page 74 . At the Fort Valley Experiment Station, located in the vicinity of Flagstaff and nearer to the San Francisco Peaks, the winter minimum was $4^{\circ}$ lower than at Flagstaff. At Snowflake, on the extensive Mogollon Plateau, and at Fort Apache, in the cold-air drainage of one of the main forks of the Salt River, there were also minima which were respectively $9^{\circ}$ and $3^{\circ}$ lower than at Marshall Gulch, although these stations are respectively 2,000 and 2,400 feet lower than Marshall Gulch. Fort Huachuca is located at the base of the Huachuca Mountains in such a manner as to escape cold-air drainage from any of the large cañons of that range of mountains, and its absolute minimum was $6^{\circ}$ higher than that of Fort Apache, which is of approximately the same elevation. Chlarson's Mill is situated in Frye Cañon in the Pinaleno (Graham) Mountains, surrounded by heavily forested slopes. Its location is analogous to that of Marshall Gulch, being similarly situated in an isolated desert mountain and surrounded by heavily forested slopes. The single monthly minimum available for Chlarson's Mill is $15^{\circ}$, for a month in which the minimum at Tucson was $18^{\circ}$, while it was $7^{\circ}$ for the Fort Valley Experiment Station, at almost the same elevation as Chlarson's Mill.

An inspection of the absolute minima for 1913-14, in table 17, will show that the same relations hold true between the several stations that have just been discussed. The winter minimum for Tucson, $26^{\circ}$, was much higher than in the preceding winter, and so was that for Marshall Gulch, $15.5^{\circ}$, although the absolute minimum in the new station on the fire tower at Mount Lemmon was $3^{\circ}$, and in the heavy timber on the north face of Mount Lemmon was $5^{\circ}$.

The data just discussed amply bear out the statement that the lowest temperatures of winter are less severe on the Santa Catalinas than they are at the same elevation on the plateau of north-central Arizona, and even less severe than they are in many situations of lower altitude. The fragmentary records of earlier years at Chlarson's Mill, which are not given here but are available in publications of the Weather Bureau, show that it is likewise favored by lower winter temperatures than are the plateau stations of the same elevation in Arizona. The length of the frostless season has just been shown to be less in the Santa Catalinas and in the Pinaleno Mountains than at Flagstaff. In short, the indications are very strong that all phases of winter temperature conditions are less severe on the small and isolated desert mountains than on the plateaus and highlands of the same elevations and of nearly 
the same latitude. The radiation of the desert valleys and the diurnal convection currents of warm air are not without a strong ameliorating influence on the climate of elevated but small masses of land.

\section{DEPARTURES FROM THE NORMAL TEMPERATURE GRADIENT DUE TO COLD-AIR DRAINAGE.}

The ideal conditions of uniform decrease of temperature with increase of altitude are seldom actually encountered in nature, at least not in mountains of small size and rugged topography. The principal factor which brings about departures from the normal or ideal gradient of fall is the operation of cold-air drainage, or inversion of temperatures. This is a phenomenon which has long been known and has frequently been discussed with respect to its influence on vegetation. In an earlier paper * the writer has described some observations of temperature inversions at the Desert Laboratory and in the Santa Catalinas, and has pointed out the causes involved in making cold-air drainage much more pronounced in deserts than it is in humid and forested regions.

The scanty vegetation of the desert subjects its soil, rocks, and sands to full insolation and to a pronounced heating throughout the day. The dark rocks of Tumamoc and other volcanic hills in its vicinity become so hot during the long clear days of May and June that it is impossible to hold one's hand on them without pain. During the day there is a constant and active radiation of heat from the rocks and soil, which warms the lowest layers of air and causes a convectional heating of the lowest portion of the atmosphere. Immediately after sunset the warmed surfaces become rapidly cooler and the rate of radiation is quickly reduced. The air nearest the cooling rocks and soil becomes cooler than the air above it, and consequently begins to fall by gravity before there is opportunity for it to mix with the warmer air above. This cooled air descends from hillsides and even from gentle slopes and soon collects in valleys and depressions, where it results in a slowly or rapidly moving mass of air which is appreciably cooler to the senses than is the air of the slopes or hillsides. The inversion of temperature thus caused usually reaches its maximum during the first half of the night, although this is determined in great measure by the size of the drainage area.

It is only on clear and still nights that cold-air drainage operates in the most pronounced manner. A high wind will disturb the flow or completely eliminate it. Heavy cloudiness will cause the rate of radiation to lag so that there is time for an admixture of cool and warm air, thereby preventing the flow of cold air or greatly reducing it.

On clear nights which follow heavy rains the inversion of temperature will be reduced to a negligible amount, because of the increase of the specific heat of the soil brought about by its becoming wet.

* Shreve, Forrest. Cold Air Drainage. The Plant World, 15: 110-115, 1912. 
It has been shown in the paper to which reference has been made that the Desert Laboratory is situated well above the level of the cold-air flow of the Santa Cruz Valley, 335 feet below it. The greatest observed difference of minimum temperature in a single night between the Laboratory and the Valley was $24^{\circ}$, and the greatest difference between the mean monthly minima of the two localities was $17.8^{\circ}$ for May. During the humid mid-summer the mean monthly difference falls to $8^{\circ}$ and $9^{\circ}$ for these stations.

TABLE 18.-Minimum temperature records to show the operation of cold-air drainage in the open vegetation of Soldier Canon and Bear Canon and its abeyance in the heavy forest of Marshall Gulch.

In each case one record is from the floor of the cañon and the other from its slopes or rim. The minus differences indicate a higher temperature on the floor and the absence of cold-air drainage.

\begin{tabular}{|c|c|c|c|}
\hline Dates. & $\begin{array}{l}\text { Slope or } \\
\text { rim. }\end{array}$ & Floor. & Difference. \\
\hline 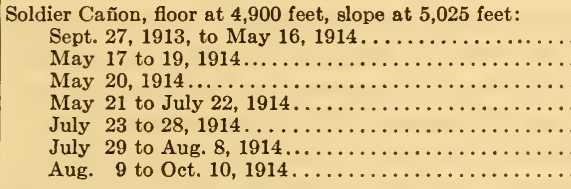 & $\begin{array}{l}18 \\
49 \\
52 \\
45 \\
60 \\
63 \\
40\end{array}$ & $\begin{array}{l}18 \\
42.5 \\
44 \\
39 \\
60 \\
62 \\
40\end{array}$ & $\begin{array}{l}0 \\
6.5 \\
8 \\
6 \\
0 \\
1 \\
0\end{array}$ \\
\hline 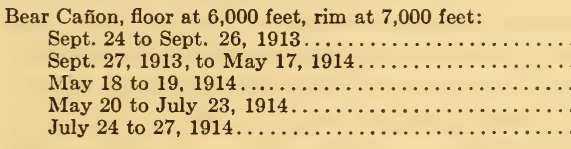 & $\begin{array}{l}38 \\
12 \\
47 \\
38 \\
52\end{array}$ & $\begin{array}{r}33 \\
6 \\
38 \\
34 \\
54\end{array}$ & $\begin{array}{r}5 \\
6 \\
9 \\
-\quad 2\end{array}$ \\
\hline 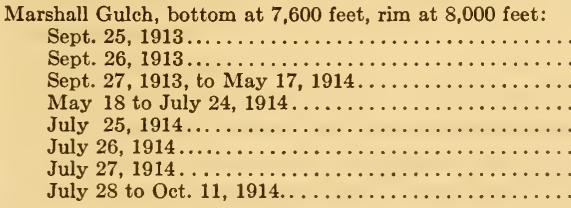 & $\begin{array}{c}34.5 \\
30.5 \\
5 \\
33.5 \\
50.5 \\
48.5 \\
51.5 \\
29.5\end{array}$ & $\begin{array}{l}33.5 \\
31.5 \\
15.5 \\
51.5 \\
49.5 \\
50.5 \\
51.5 \\
32.5\end{array}$ & $\begin{aligned} & 1 \\
&- 1 \\
&- 10.5 \\
&- 18 \\
& 1 \\
&- 2 \\
& 0 \\
&- 3\end{aligned}$ \\
\hline
\end{tabular}

The vigor of cold-air drainage is determined not only by the conditions of cloudiness and wind but also by the size and nature of the area from which the cold air is derived and by the character of the valley bottom through which it moves. In the Santa Cruz Valley cold air is derived from an area of more than 1,000 square miles, resulting in the pronounced low temperatures shown in tables 16 and 18 . The broad level trough of the valley is conducive to a slow movement of the air, and the nocturnal minimum is usually reached during the last hours of darkness. The valleys of the Salt and Gila Rivers are larger than the valley of the Santa Cruz, and they have their sources in still higher mountains, but they do not seem to possess a well-marked 
cold-air drainage, to judge by the minimum temperature records for the towns on the lower courses of these rivers, as Florence and Phœnix. It is possible that in traveling long distances at nearly the same altitude the cold air is gradually warmed by mixture with the warm air above it.

During the winter of 1913-14 and the summer of 1914 thermometers were exposed in the Santa Catalinas so as to give a basis for comparing the cold-air drainages of the mountain with the drainage of the Santa Cruz Valley as investigated at the Desert Laboratory. Table 18 shows the readings of instruments placed so as to reveal the differences of temperature due to cold-air drainage, at three localities of different elevation. The first locality is in Soldier Cañon, in the open Encinal, where readings were taken on the floor of the cañon, at 4,900 feet and on its slope at 5,025 feet. The lowest minima of the winter were identical at the two stations, which can be accounted for only on the possibility of the stream of cold air having become so deep as to reach the upper thermometer, or else on the possibility that the lowest minimum of the winter occurred on a cloudy or very windy night. During three intervals in the arid fore-summer the depression of the temperature in the floor of the cañon was $6.5^{\circ}, 8^{\circ}$, and $6^{\circ}$ respectively, whereas throughout the humid mid-summer the depression was absent or negligible.

The regular 7,000-foot station is located on the rim of Bear Cañon, and the data from it may be compared with those from an instrument placed in the floor of the cañon 1,000 feet below. This station may further be compared with the 6,000-foot station located on the summit of Manzanita Ridge. In spite of the difference of 1,000 feet in the elevation of the two thermometers in Bear Cañon, the lowest temperature of the winter was $6^{\circ}$ in the Cañon and $12^{\circ}$ on the rim. A two-night interval in the autumn of 1913 gave a difference of $5^{\circ}$ between these stations, due to air drainage, and during the arid fore-summer of 1914 differences of $9^{\circ}$ and $4^{\circ}$ were obtained. During the three particularly cloudy and rainy nights in July there was an actual reversal of the conditions of cold-air drainage and a manifestation of the true temperature conditions to be expected from altitude alone, the rim having a minimum $2^{\circ}$ lower than the floor. Although the winter minimum of $1913-14$ was $6^{\circ}$ in the floor of Bear Cañon at 6,000 feet, it was $18^{\circ}$ on Manzanita Ridge at 6,000 feet. This difference of $12^{\circ}$ between two stations at the same altitude is as great as should be expected, under the operation of the normal gradient of temperature, between localities 3,468 vertical feet apart $\left(12^{\circ} \div 3.46^{\circ}\right.$, the rate of fall per 1,000 feet $)$.

Although there are some small bodies of forest on the walls of Bear Cañon and many scattered trees, nevertheless the surface of its sides is largely occupied by cliffs and boulders (see plate 21), and these are responsible for the acute operation of the drainage phenomenon.

Several preliminary tests had shown an extremely weak manifestation of cold-air drainage at the heavily forested elevations of the Santa 
Catalinas. The data presented in table 18 for the rim of Marshall Gulch at 8,000 feet, and for the Montane Garden at 7,600 feet, bear out the results of the preliminary tests. The rim was $10^{\circ}$ colder than the bottom of the gulch in the over-winter period and $18^{\circ}$ colder in the period from May 18 to July 24. The 5 one-night readings and the readings for the period from July 28 to October 11 all show an equality or a slight difference, more often a difference, with the temperature more commonly higher in the bottom of the Gulch than on the rim. In other words, cold-air drainage is in abeyance at this locality. Whether this is invariably the case can only be stated after further instrumentation and after complete assurance that the readings have not been influenced by the character of the weather during the nights of lowest temperature. The heavy vegetation of the Forest region, together with the high humus content of the soil and the litter of leaves by which it is covered, all militate against the rapid terrestrial radiation in which cold-air drainage has its origin. It will not be surprising, therefore, to find that the phenomenon is either very weak or absent above the elevation of 7,000 feet in such portions of the mountain as are forested. The elimination of cold-air drainage by a forest cover can take place only in small mountains which are forested to the summit. A large mountain mass, an extremely steep mountain side, or an extensive area lying above timber line will cause a flow of cold air down through forested areas below. This is exemplified at the San Francisco Peaks, Arizona.

The case mentioned in which cold-air drainage occasioned a difference of temperature at the same altitude, which was the equivalent of nearly 3,500 feet, probably represents its maximum effect. The difference of $8^{\circ}$ in Soldier Cañon is the equivalent of an altitudinal difference of about 2,200 feet.

The influence which cold-air drainage exerts on vegetation is registered chiefly in the shortening of the season of vegetative activity on the floor of a cañon as contrasted with its sides. This effect has been repeatedly observed in Bear Cañon, where the oaks on the floor of the cañon are always far behind the individuals on the cañon wall in the advancement of their new foliage in the spring. Likewise in the autumn the frost-killing of herbaceous perennials and of the leaves of Prunus, Rhus, and Populus jamesii takes place in the floor of the cañon, while the herbaceous plants of the slopes are still green and active. The plants on the cañon floor are, in other words, subjected to a growing season similar to that usually found at a much higher altitude.

The influence of cold-air drainage in determining the distribution of plants is likewise marked. It is not wholly responsible for the fact that mountain species extend down the cañons to lower altitudes than they assume on slopes or ridges, for the influence of ground water and soil moisture is very potent in this connection. The occurrence of the 
highest individuals of every species-other than those of aquatic or streamside habitat - on or near the summits of ridges, and their invariable absence from the bottoms of cañons at these higher elevations, are to be attributed to the absence of cold-air drainage from the ridges and higher slopes, together with the influences grouped in the "factor" of slope exposure.

\section{SOIL TEMPERATURE}

In the autumn of 1913 instruments were placed at the 6,000-and 8,000foot stations to secure the absolute winter minimum temperature of the soil at a depth of $3 \mathrm{~cm}$., and the thermometers were maintained in

TABLE 19.-Minimum temperatures of the soil and of the air at 3 elevations in the Santa Catalina Mountains for irregular periods.

\begin{tabular}{|c|c|c|c|}
\hline Station. & $\begin{array}{l}\text { Air } \\
\text { temperature. }\end{array}$ & $\begin{array}{c}\text { Soil } \\
\text { temperature. }\end{array}$ & Difference. \\
\hline \multirow{7}{*}{$\begin{array}{l}\text { At } 6,000 \text { feet: } \\
\text { Sept. } 23 \text { to Sept. } 27,1913, \ldots \ldots \\
\text { Sept. } 28,1913, \text { to May } 16,1914 \\
\text { May } 17 \text { to } 19 \ldots \ldots \ldots \ldots \ldots \ldots \\
\text { May } 20 \text { to July } 22 \ldots \ldots \ldots \ldots \ldots \ldots \\
\text { July } 23 \text { to } 27 . . \ldots \ldots \ldots \ldots \ldots \ldots \\
\text { July } 28 \text { to Oct. } 10 \ldots \ldots \ldots \ldots \ldots\end{array}$} & & & \\
\hline & 42 & 47 & +5 \\
\hline & 18 & 28 & +10 \\
\hline & 53 & 51 & -2 \\
\hline & 44 & 45 & +1 \\
\hline & 58 & 60 & +2 \\
\hline & 40 & 42 & +2 \\
\hline \multirow{10}{*}{ 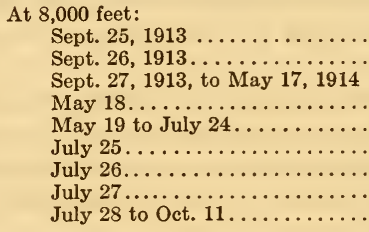 } & & & \\
\hline & 34.5 & 41 & +6.5 \\
\hline & 30.5 & 37 & +6.5 \\
\hline & 5 & 30 & +25.0 \\
\hline & 39.5 & 43 & +3.5 \\
\hline & 33.5 & 41 & +7.5 \\
\hline & 50.5 & 69 & +18.5 \\
\hline & 48.5 & 58 & +9.5 \\
\hline & 51.5 & 57 & $\begin{array}{r}5.5 \\
\end{array}$ \\
\hline & 29.5 & 39 & +9.5 \\
\hline \multirow{2}{*}{$\begin{array}{l}\text { At } 7,600 \text { feet: } \\
\quad \text { Sept. } 25,1913 \ldots \ldots \ldots \ldots \ldots \ldots\end{array}$} & & & \\
\hline & 33.5 & 39 & +9 \\
\hline
\end{tabular}

place and read at irregular intervals during the summer of 1914. The object in placing the thermometers at so slight a depth was to obtain a measure of the activity of terrestrial radiation by a comparison of the superficial minima of the soil and the atmospheric minima. The ordinary type of Six's thermometer was used, buried in a wooden box and covered with earth. The readings secured in this manner and the readings of atmospheric minima for the corresponding periods at the same stations are given in table 19.

At the 6,000-foot station the soil minima are higher than the air minima in every case except one, the over-winter difference being $10^{\circ}$. At the 8,000-foot station all of the 9 readings secured show a higher minimum for the soil. The over-winter period shows a difference of $25^{\circ}$, and the night of July 25 shows a difference of $18.5^{\circ}$. The readings 
show that the soil temperatures at 6,000 feet were cooler in general, in terms of the air temperature, than were those of the 8,000-foot station. This difference is not to be attributed to the difference of elevation so much as to the naked and stony character of the soil at the 6,000-foot station and the relatively abundant humus and litter in the surface soil at 8,000 feet. In short, the radiation from the soil surfaces in the Encinal is greater than it is in the Forest, as has been already discovered from the difference in the behavior of cold-air drainage in these two regions. There is also a slight indication that the differences between the air and soil minima are least in the dry seasons of May and September, which is again in keeping with the greater radiation exhibited in dry soils as compared with wet ones.

On the night of September 25, 1913, the difference between the air and soil temperatures was simultaneously determined on the rim of Marshall Gulch at the 8,000-foot station and in a thicket of young fir trees in the bottom of the gulch. The soil remained $6.5^{\circ}$ warmer than the air on the rim of the gulch and $9^{\circ}$ warmer in the fir thicket, showing the degree to which a heavy cover of vegetation retards radiation and conserves the warmth of the soil. On this night the air temperature in the bottom of the gulch was $1^{\circ}$ lower than that on the rim (see table 18).

One of the most striking features of the soil minima is the fact that although the air temperature at 8,000 feet fell to $5^{\circ}$ in the winter of $1913-14$, the soil temperature fell only to $30^{\circ}$. This means that in the open forest on the rim of Marshall Gulch the soil must have been very slightly if at all frozen in the winter in question, which was apparently a winter of about average severity. During the same winter a lower absolute minimum of the soil was recorded at 6,000 feet than at 8,000 feet. In shaded situations and on north slopes in the Fir Forest the soil undoubtedly freezes to a slight depth. Inasmuch as no soil temperatures have been secured with the bulb of the thermometer in contact with the soil, and no readings have been secured at a greater depth than $3 \mathrm{~cm}$., the further discussion of soil temperature conditions in these mountains should await further investigation. 


\section{CORRELATION OF VEGETATION AND CLIMATE IN THE SANTA CATALINA MOUNTANS.}

The earlier chapters of the present paper have described the salient features of the vertical distribution of vegetation in the Santa Catalinas, and also some of the principal gradients of climatic change. Both the vegetation and the climate have been shown to exhibit progressive changes with increase of altitude, and these changes have been found to undergo hastening or retardation under the influence of topographic irregularities. It will be the object of the following pages to correlate, in so far as possible, the altitudinal changes of vegetation and climate, in an effort to determine roughly some of the physical factors which are of critical importance in limiting the vertical ranges of the types of vegetation and of their characteristic species.

\section{THE NORMAL ALTITUDINAL GRADIENT OF VEGETATION.}

Any attempt to ascribe vertical limits to the Desert, Encinal, and Forest, or to state the vertical limits of individual species, is met at once by the omnipresent importance of slope exposure in determining these limits. The altitudinal range of vegetations and species may be determined by examining only slopes of south exposure, or only those of north exposure, and the two examinations would agree closely as respects the vertical ranges, but would disagree by approximately 1,000 feet with respect to the upper and lower limits of the vegetations or species. It is impossible to determine the normal character of vegetation at a given altitude by seeking level ground, for it will be found only in the flood-plains, subject to the influence of a high soil moisture, or on a ridge, subject to equally special conditions. It is also impossible to visit adjacent valleys or plateaus lying at the same elevation and to find on them vegetation which is subject to the same climatic and soil conditions. For some purposes it is desirable to consider the vertical stages of vegetation under ideal conditions, as affected by altitude without the complications due to topographic features. It is then possible to hypothecate a norm of vertical stages of vegetation by averaging the altitude of any given limit as separately determined on north and south slopes, or it is possible to take into consideration only the altitudinal changes of south slopes or of north slopes, taken alone.

It has been shown that the influence of topography on the vegetation is chiefly (sometimes solely) to carry the common types of vegetation above or below the elevations at which they are universal. The influence of topography on the gradients of climate is of the same character; the topographic relief causes no wholly new factors to come into play, but serves merely to carry the physical conditions of the Desert into the Encinal, for example, or to bring the conditions of the Forest 
down into the Encinal. The physical factors which underlie the effects of topography are, then, to be considered simply as special cases of the same influences that are grouped in the effects of altitude itself. It is desirable, nevertheless, in studying the correlation of climate and vegetation to consider separately the normal gradient of vegetation and the departures from the normal gradient.

\section{THE VERTICAL DISTRIBUTION OF INDIVIDUAL SPECIES,}

The student of vegetation too often loses sight of the fact that vegetation is composed of individual species of plants and that the behavior of the vegetation is a function of the behaviors of these species. After our review of the vegetation of the Santa Catalinas, and in connection with the discussion of its control by climatic factors, it is necessary to consider the vertical distribution of the individual species in relation to the physical conditions of the mountain.

There are no species of plants which grow spontaneously both at the base and the summit of the Santa Catalina Mountains, except a few palustrine forms of Carex and Juncus. The total range of physical conditions through the 6,000 feet of elevation here involved is so great that no native plant possesses the power of accommodation to the complete gamut of Desert, Encinal, and Forest. Indeed, very few plants range through half of the entire gradient of conditions, in any portion of it. The species which exhibit the widest belts of vertical distribution are to be found in the most dissimilar habitats at the lower and upper edges of their ranges, which indicates that these species are not really capable of existence through 2,000 or 3,000 vertical feet of the climatic gradient under the same conditions of topographic location, slope exposure, and insolation. In fact, a close analysis of the habitats occupied by characteristic plants, in connection with their vertical ranges, indicates that, below 6,000 or 7,000 feet, no plants outside the desert succulents and semi-succulents range through more than 1,000 to 1,500 feet in habitats of the same topographic character. At higher elevations a number of common plants extend more than 1,500 feet in situations of the same character, as for example Pinus arizonica, which ranges through nearly twice that altitude on dry southern slopes.

A vertical range of 4,700 feet is exhibited by Vitis arizonica, which occurs in several arroyos and cañons at 3,000 feet and is found in the same habitat throughout the Desert and Encinal regions of the mountain, reaching its highest observed station at 7,700 feet in a steep dry arroyo in the Pine Forest. Although the habitat of Vitis is superficially identical throughout its range, it is found at 3,000 to 5,000 feet only in the largest arroyos, in which it is able to draw upon much greater and more constant supplies of soil moisture than are available in the small arroyos to which it is confined at the upper edge of its range. 
Robinia neomexicana ranges through 3,800 feet, from its lowest occurrence on flood-plains near constant water at 5,300 feet, to its highest occurrence on dry ridges near the summit of Mount Lemmon at 9,100 feet. On the higher mountains of southern Arizona this species ascends to over 10,000 feet. Amorpha californica, after the manner of Vitis, ranges 3,500 feet from moist arroyos at 4,200 feet to dry ones at 7,700 feet. Agave palmeri ranges from dry slopes of east or west exposure at 3,200 feet to open ridges and crevices of rock at 7,400 feet, a belt of 4,200 feet. Among the species which reach neither the Bajada nor the top of the mountain there are no others with vertical extensions of more than 4,000 feet. An extreme range of 3,700 feet is possessed by Juniperus pachyphloea, from northern slopes at 4,200 feet to ridges at 7,900 feet. Nolina microcarpa extends from 3,750 feet on north slopes to 7,200 feet in open pine forest, a range of 3,450 feet, and Dasylirion wheeleri from 3,600 feet to 6,600 feet, on opposing slopes, a range of 3,000 feet.

Among other plants which occur chiefly in the Encinal Region there are none with vertical ranges in excess of 3,000 feet, few in fact approach that range. Pinus cembroides extends from north slopes at 5,000 feet to open rocky ridges at 7,800 feet, a range of 2,800 feet; Agave schottii ranges from 3,700 to 6,000 feet, a belt of 2,300 feet; Garrya wrightii ranges from 4,300 to 6,500 feet, an extent of 2,200 feet; and Quercus emoryi extends from north slopes at 4,300 feet to south slopes at 6,200 feet, a vertical range of 1,900 feet.

Among the plants which have their lowest occurrence in the floodplains of the Encinal and their principal range through the Forest Region, a number have vertical belts of occurrence of more than 3,000 feet. Pinus arizonica itself is found through 3,300 feet and its upper limit is determined only by the height of the mountain. Pseudotsuga mucronata is found through 3,100 feet, and is also terminated by the summit of the mountain. Quercus hypoleuca and Quercus reticulata are found through nearly 3,000 feet, and this extent of vertical range is attained by a large number of herbaceous perennials of the Upper Encinal and Forest.

The Desert species which are encountered at the foot of the mountain do not begin their vertical ranges at that point, and statements of the elevations which they reach on the mountain are not to be compared with figures for the ranges of Encinal and Forest plants. Mamillaria grahami reaches the attenuated limit of its occurrence at 7,000 feet, Echinocactus wislizeni at 5,600 feet, Fouquieria splendens at 5,600 feet, Opuntia versicolor at 5,500 feet, and Carnegiea gigantea at 5,100 feet. Very few other species of the bajadas and desert hills are found above 4,700 feet.

Among the most restricted vertical ranges of any plants which reach neither the foot nor the summit of the mountain are those of Quercus 
oblongifolia and Vauquelinia californica. If we except the occurrence of the former in the beds of Sabino and Ventana cañons at 3,000 to 3,200 feet, its lowest occurrence on slopes is at 3,900 feet and its highest at 5,600, a range of 1,700 feet; while Vauquelinia ranges from 3,900 to 5,500 feet, a vertical range of only 1,600 feet. These limits also apply very nearly for Erythrina flabelliformis, Ingenhousia triloba, and several shrubs and shrublets, and are only slightly exceeded by the range of Quercus emoryi, which has already been stated to be 1,900 feet.

Certain species of plants are confined to arroyos throughout their vertical ranges, as are Vitis arizonica, Amorpha californica, Platanus wrightii, and Juglans rupestris; or are found chiefly in arroyos, as Cupressus arizonica and Acer interior. The great majority of trees, shrubs, and shrublets, as well as the semi-succulents (such as Agave, Yucca, Nolina, and Dasylirion), are found on slopes and ridges in at least some portions of their ranges, or are chiefly found there. The oaks, the deciduous trees, and most of the shrubs may be found along arroyos, or in flood-plains at elevations from 500 to 1,000 feet below the level at which they become common components of the slope vegetation. The semi-succulents, like the succulents, are rarely found in arroyos, although they may grow very close to them or may be found in dry flood-plains. Of all species not confined to arroyos, their lowest occurrences are generally to be sought on north slopes or in arroyos at even lower elevations, and their highest occurrences are to be sought on south or southwestern slopes or (particularly in the case of cacti) on rocky ridges. At the vertical center of the distributional range of these species they may be found, as a rule, on slopes of every exposure, and perhaps in flood-plains as well, particularly in the case of the evergreen oaks. The exceptions to the rule are Quercus oblongifolia, which is commoner on south slopes than on north ones at all parts of its vertical range except the very lowest, and Pinus chihuahuana, which is rarely found on north slopes at any part of its range, even its lowest occurrences being on south slopes or on an approximate level.

\section{PHYSICAL FACTORS INVOLVED IN THE DETERMINATION OF THE NORMAL} ALTITUDINAL GRADIENT OF VEGETATION.

In order to overlook for the moment all of the subsidiary influences which cause local disturbance of the vegetistic gradient let us consider that the southern slopes at all elevations are representative of the normal altitudinal changes of vegetation, and let us then consider some of the differences of physical conditions that accompany the ascent from 3,000 to 9,000 feet. The differentiations of vegetation which we are accustomed to designate as "due to altitude" are actually due to three groups of physical factors: (a) moisture factors, (b) temperature factors, $(c)$ light factors. It has been customary to regard atmospheric pressure as a negligible agency in relation to plants, but 
there is no work known to the writer which proves or disproves this view. The light factors have been but little investigated and may prove to occupy a rôle of great importance. In spite of the fundamental physiological rôle of light, it is more than probable, however, that this factor plays a less important part in influencing the distribution of plants than do moisture and temperature.

\section{MOISTURE FACTORS.}

In the case of a mountain which arises from an arid region to a considerable height, the moisture factors are of critical importance in controlling the vertical distribution of plants. This group of factors may be defined as those which have to do with the maintenance of a close degree of equality between the daily intake and outgo of water through the plant. The description of rainfall and soil moisture conditions in the Santa Catalinas has indicated the nature of the water supply for plants, and the data on atmospheric evaporation have shown the collective force of the chief of those ultimate external factors which determine the water loss of plants. During the humid seasons the ratio of water available to water lost is such as to make conditions favorable for all plants. During the most acute periods of aridity the value of this ratio becomes an item of the first moment.

The soil moisture data given in an earlier section are from too slight a depth to indicate the possible supplies for trees and the largest shrubs. They are nevertheless from a depth which is freely exploited by the roots of perennial plants, and it is more than likely that they bear a rather definite ratio to the moisture at greater depths.

Since the arid fore-summer is the portion of the year in which the maintenance of an equilibrium between intake and outgo of water is most difficult, it is instructive to determine their relation for this season at the different altitudes. This may be done by determining the ratio of evaporation (in terms of cubic centimeters per day) to soil moisture (in percentage of dry weight), using the average daily evaporation of the arid fore-summer, and the average soil moisture of the arid foresummer at $15 \mathrm{~cm}$. These ratios are exhibited in table 20. The approximate ranges of the ratios are 1 to 25 for the Forest, 20 to 35 for the Encinal, and 35 to 50 for the Desert. If evaporation data had been secured at 9,000 feet the value of the ratio for that elevation would have been less than unity.

The values of the ratio of evaporation to soil moisture afford a concise expression of the major conditions which affect the water relations of plants, and they demonstrate the wide divergence of these conditions in the desert valleys and on the forested mountain summits during the arid fore-summer. The average daily evaporation rate has been shown (fig. 12) to fall during the humid mid-summer to half the amount during the arid fore-summer. The soil moisture is like- 
wise increased in the former season to an amount that would greatly reduce the values of the ratio if determined for the humid mid-summer.

The ratio of evaporation to soil moisture is not in itself a full index of the comparative aridity of Desert, Encinal, and Forest, for the conditions expressed by the ratio are of much longer duration at 3,000 feet than at 8,000 feet. The shortening of the arid fore-summer from 16 weeks at 3,000 feet to 7 weeks at 8,000 feet (see fig. 2) signifies that the most severe drought conditions of the year are more than twice as prolonged at the lowest elevation as compared with the uppermost. It is necessary here to bear in mind that the effects of drought on plants are cumulative, and that, for example, a period with a given set of conditions of increasing aridity which endures for 16 weeks may be twice as fatal or deleterious as a period that lasts for 14 weeks. For purposes of general climatic description, however, the values of the ratio of evaporation to soil moisture multiplied by the duration of the arid fore-summer may be taken as an index of the aridity of the several elevations (see table 20).

TABLE 20.-Average daily evaporation $(E)$ and the moisture of the soil (SM), together with the ratio of evaporation to soil moisture $\left(\frac{E}{S M}\right)$ for north and south exposures at six elevations in the Santa Catalina Mountains for the arid fore-summer of 1911.

\begin{tabular}{|c|c|c|c|c|c|c|}
\hline Elevation. & $\begin{array}{l}\text { Expo- } \\
\text { sure. }\end{array}$ & Vegetation. & $E$ & $S M$ & $\frac{E}{S M}$ & $\begin{array}{l}\text { Duration of } \\
\text { arid } \\
\text { fore-summer. }\end{array}$ \\
\hline 3,000 feet.. & $\mathrm{s}$ & Desert....... & 101.1 & 2.0 & 50.5 & 16 \\
\hline 4,000 feet.. & $\mathrm{S}$ & Desert. . & 80.4 & 2.0 & 40.2 & \\
\hline 4,000 feet... & $\mathrm{N}$ & Encinal. & 82.7 & 2.5 & 33.1 & 14 \\
\hline 5,000 feet.... & $\mathrm{s}$ & Encinal. & 61.7 & 3.1 & 19.9 & \\
\hline 5,000 feet.... & $\mathrm{N}$ & Encinal. . & 74.4 & 3.5 & 21.3 & 13 \\
\hline 6,000 feet.... & s & Eneinal.. & 59.4 & 1.8 & 33.0 & \\
\hline 6,000 feet.... & $\mathrm{N}$ & Forest... & 56.1 & 3.5 & 16.0 & 11 \\
\hline 7,000 feet $\ldots$ & S & Forest.... & 62.8 & 2.6 & 24.1 & \\
\hline 7,000 feet... & $\mathrm{N}$ & Forest.... & 49.9 & 5.5 & 9.1 & 9 \\
\hline 8,000 feet.. & $\mathrm{s}$ & Forest. . & 29.3 & 7.4 & 3.9 & \\
\hline 8,000 feet... & $\mathrm{N}$ & Forest... & 29.4 & 11.3 & 2.6 & 7 \\
\hline
\end{tabular}

The ratio of evaporation to soil moisture comprises a measurement of all the external factors which affect the water relations of plants, except the influence of radiant energy on transpiration and the possible effects of soil temperature on this function. It is accordingly unnecessary to give further consideration to rainfall, which is not in itself a factor for vegetation, at least in such a region as Arizona. If any differences existed between the seasonal distribution of rainfall at different elevations in the Santa Catalinas the fact would be of great importance to the vegetation, but only in the effect it would have on the annual march of the soil moisture conditions. The evidences of observation and instrumentation have shown that the major drought 
periods of the Desert are rarely broken on the mountain by rainfall of significant amount.

The records of rainfall for 8 years show that the summer rain at 8,000 feet may be from 1.9 to 3.5 times as great as that at 3,000 feet (see table 4). The average of the 8 years shows the summer rain at 8,000 feet to be about 2.4 times that on the Desert. The average of a longer series of years will probably approximate this amount and the securing of the winter precipitation would probably make little difference in the proportion.

The very conditions of low evaporation which favor the water relations of the plants in the Forest region are also favorable to the preservation of the moisture of the soil. The effect of the winter rains upon the soil moisture of the Forest is accordingly carried forward many weeks (see table 7 for soil moisture at 9,000 feet after 6 weeks without rain). The slow melting of snow on north slopes still further prolongs the effect of winter precipitation. These causes underlie the vernal activity of herbaceous plants in the Forest region (see p. 29) and the growth by trees of the Forest region during the arid fore-summer.

\section{TEMPERATURE FACTORS.}

The rôle played by temperature in differentiating the vegetation of the various altitudes of the Santa Catalinas is by no means so simple a matter as that played by moisture conditions, and is far from being capable of expression in a concise mathematical form. It has already been shown that the frostless season decreases from a length of 40 weeks on the Desert to a length of 19 weeks in the Forest at 7,600 feet (see tables 10 and 11, and fig. 2), and that the temperature has an average apartness of $26^{\circ}$ between Desert and Forest (see table 13). No instrumentation has been carried on which would establish the quantitative nature of the difference between other phases of the temperature conditions. The shortening of the growing season with increase of altitude, and the concomitant lowering of the temperatures of this season, are factors of great moment to the vegetation, but no work has been done to establish the precise temperature and temperature-duration requirements of any species of plants. The shortness of the growing season in the Forest and the coldness of the nights of mid-summer $\left(40^{\circ}\right.$ to $50^{\circ}$, see table 14$)$ are both hostile to growth activity and may well be limiting factors in the upward distribution of many species of the Encinal.

The temperature conditions of winter are equally important with those of summer in underlying the limitation of species and vegetations, and their rôle may be played independently from that of the summer temperature conditions, or the two may play conjointly upon the same species at the same altitude. Among the various phases of winter temperature conditions are the length of the period subject to frost, 
the number of days with freezing temperature, the number of consecutive days or hours of freezing, and the absolute minimum reached. Any two or more of these phases may operate conjointly to influence a plant, and the temperature preceding a particular constellation of conditions may enhance the harmful effects of those conditions. In fact the general weather conditions accompanying or following a given phase of temperature may determine the full effect of the temperature.

In those cases in which plants are killed by the action of low temperatures the most important factor to be considered is the actual duration of the period during which the plant is subjected to temperatures below $32^{\circ}$. Secondary to this are the considerations of the amount of precooling received by the plant, the actual minimum temperature to which it was taken, the condition of the soil and the atmosphere during the freezing, and the nature of the weather subsequent to it. In a previous paper* the writer has called attention to the manner in which the most critical phase of low temperature conditions increases in severity with increase of altitude. Even on the coldest winter days the temperature on the Desert never fails to rise above $32^{\circ}$ during the mid-day. The lowest temperatures of winter are invariably accompanied by a clear sky, and the days preceding and following very cold nights are clear. A cloudy or rainy period is always accompanied by more moderate temperatures, as is shown by the rarity of snow on the Desert itself. The longest duration of a shade temperature below freezing, in the ten-year records of the Desert Laboratory, is 19 hours. It frequently happens that a duration of 6 hours is the greatest for an entire winter. On ascending the mountains the length of the most prolonged period of freezing becomes greater until an altitude is reached at which there are occasional winter days when the air temperature does not rise above freezing. At this altitude there is a sudden increase in the maximum number of hours of frost from 22 or 23 hours to a length of 40 to 45 hours. Such a sudden intensification in the duration of a critical climatic condition causes this condition to operate more sharply in the limitation of plant distribution than is the case with conditions that exhibit the usual form of slowly graduated change.

No winter thermograph records have been secured in the Santa Catalinas, and it is therefore impossible to state the exact altitude at which this sudden intensification of the frost factor becomes manifest. It is probable that it lies at about 4,500 feet. The exposure of plants to insolation may often save them from the effects of an air temperature of less than $32^{\circ}$, and in the case of succulents the temperature to which their tissue is raised during the insolation of the preceding day will shorten the period of freezing for them. These subsidiary matters

\footnotetext{
* Shreve, Forrest. The Influence of Low Temperatures on the Distribution of the Giant Cactus. The Plant World, 14: 136-146, 1911.
} 
affect the exact altitude at which the maximum number of freezing hours may operate in the limitation of a given species; and the exact topographic character of the location of an individual plant may also affect the operation of this factor.

The experimental work of the writer has shown that a duration of more than 18 hours of freezing temperature is fatal to Carnegiea and that Opuntia versicolor and Echinocereus polyacanthos are capable of withstanding durations of 66 hours. The limitation of Carnegiea is apparently due to the operation of this factor. Its occurrence becomes confined to south slopes at 4,000 feet and it becomes less and less abundant from that elevation up to 4,500 feet. One of the highest individuals at the latter elevation is protected by a rock on its north side, above the summit of which the cactus now projects for 8 inches. This projecting top was badly frosted on its north side in the severe winter of 1912-13, while the north side of the plant below the summit of the rock was uninjured. A small Carnegiea (18 inches high) has been discovered in Soldier Cañon at 5,100 feet. It grows on the south side of a low rock, and its location is on the steep south slope which terminates a long ridge between two main branches of the cañon. The plant is here well protected from the cold-air flow of the cañon and is subjected to the full insolation of the short winter days. It showed some slight effects from the exceptionally cold winter just referred to, but succeeded in recovering from them. In the early arid fore-summer of 1911 the writer transplanted a young Carnegiea 3 inches high from the base of the mountain to the vicinity of the 6,000 -foot station on Manzanita Ridge. The cactus was placed on the southwest side of a rock, with a large plant of Arctostaphylos northeast of it, and occupied a location near the summit of the ridge. The plant was watered several times in order to help it to become established, but was not assisted after the commencement of the summer rains. It successfully passed the winter of 1911-12; it made gains in turgidity in the summer of 1912, but no measurable growth; in the spring of 1913, after the winter in which the minimum temperature at that locality was $-6^{\circ}$, the plant was found to be dead. Although the rainfall at Manzanita Ridge in the summer of 1912 was 8.68 inches as compared with 5.61 inches at the location from which the cactus was taken (near the 3,000-foot station), it was not able to seize the advantage. This fact itself involves the factor of summer temperature, which doubtless determines the rate of growth of the roots and their power for the intake of water.

The evidence which shows Carnegiea to be limited in its upward distribution by the greatest number of freezing hours is probably applicable to a large number of desert plants, non-succulent as well as succulent forms, which find their limitation at about the same elevation. 
THE RÔLE OF TOPOGRAPHIC FEATURES IN DETERMINING DEPARTURES FROM THE NORMAL ALTITUDINAL GRADIENT OF VEGETATION.

The normal or ideal gradient of vegetation is disturbed by three sets of topographic influences: (a) that of slope exposure, (b) that of the surface flow or underflow of streams and arroyos and the high soil moisture of flood-plains, and (c) that of location with respect to ridges, slopes, or valley bottoms, which may be designated briefly as the influence of topographic relief. These three sets of topographic features do not bring into operation any factors, nor any intensities of the common factors, which are not involved in the normal vertical gradients of physical factors, although in some cases they bring about new combinations of factors not exactly duplicated at other elevations under the conditions of the hypothetical normal gradient. In the description of the vegetation there have been frequent allusions to these three sets of departures from the ideal gradient of vegetation. Instrumentation has also been described which throws light upon the operation of slope exposure and of topographic relief. The influence of streams has been very obvious in its nature and has not been investigated instrumentally.

\section{THE RÔLE OF SLOPE EXPOSURE.}

The importance of slope exposure in determining the vertical limits of species, and in thereby determining the vertical range of types of vegetation, has been a matter of observation and comment among almost all writers on the vegetation of the western United States. Although the phenomenon is of universal occurrence throughout the extra-tropical portions of the globe it is rendered particularly striking in regions where there are transitions from desert or grassland into forested country. In any region like the Santa Catalina Mountains, with their steep climatic gradient and varied topography, the operation of the factors involved in slope exposure is such as to present an alternation of vegetistic regions, causing constant departures of the vegetation from the theoretical norm to the norm of higher or lower portions of the mountain.

Slope exposure is a "factor" in differentiating the vegetation of opposed slopes at all elevations. Even at altitudes between 2,000 and 3,000 feet among the volcanic hills of the Tucson region, there are conspicuous differences between the south slopes, with their heavy stands of Carnegiea, Encelia farinosa, and Opuntia bigelovii, and the north slopes with their abundant individuals of Parkinsonia microphylla and Lippia wrightii and their heavier growth of perennial grasses.* The difference between northern and southern exposures is most conspicuous between 4,000 and 5,000 feet, where the former have orchard-

* See Spalding, V. M. Distribution and Movements of Desert Plants. Carnegie Inst., Wash., Pub. 113, 1909. 
like stands of evergreen oaks and the latter are treeless (see plate 9B). Almost equally striking, however, is the contrast between the open pine forests on south slopes at 9,000 feet and the heavy, deep-shaded stands of fir on north slopes at the same elevation (compare plate $29 \mathrm{~A}$ and plate 35$)$.

Although the influences of slope exposure are operative at all elevations they acquire added power with increase of altitude.* In the Desert region and the Lower Encinal the uppermost limits of species on north slopes and on south slopes are from 600 to 1,000 feet apart (Carnegiea, Echinocactus, Quercus emoryi), while in the Forest region the upper limits on opposed slopes differ by 1,000 to 2,000 feet (Quercus hypoleuca, Juniperus pachyphloa, Arbutus arizonica). Another test of the same fact may be had by comparing a north slope at 3,000 feet with a south slope at 6,000 , and by then carrying the comparison up 3,000 feet. Between the north slope at 3,000 feet and the south slope at 6,000 feet is the strong contrast of Desert and closed Encinal, with only a few xerophilous ferns and one small cactus in common. Between the north slope at 6,000 and the south slope at 9,000 feet is the very close resemblance of two stands of Pine Forest, in one of which are still to be seen a few Encinal forms that have disappeared from the other and higher one.

The increased influence of slope exposure at higher elevations is not to be attributed to the fact that the species of the Upper Encinal and Forest range through greater elevations than do the species of the Desert and the Lower Encinal. The number of feet through which a species ranges on south slopes or on north slopes has no necessary connection with the difference between its upper limits on north and on south slopes. The ability of a large number of plants to range through a greater vertical distance in the Upper Encinal and Forest than it is possible for the plants of the lower vegetations to do may be owing to the ability of the plants of the upper portion of the mountain to withstand a greater gamut of conditions than the plants of the basal vegetations can. It would, in any event, not be due to the existence of more gradual gradients of climatic change at the higher elevations, since in every case of the measurement of these gradients they have been shown to grow steeper between 6,000 and 9,000 feet than below 6,000 feet. The increase in the effects of slope exposure with increase of altitude can only be ascribed to an increasing differentiation of the climatic conditions between north and south slopes at higher elevations. An examination of the curves of evaporation and of soil moisture (figs. 10 and 14) will show that the readings for the highest stations exhibit the greatest apartness, at least with respect to the intensities involved.

\footnotetext{
* Merriam has illustrated this fact in a diagrammatic profile of San Francisco Peak, but has not mentioned it in the text of his paper. See Merriam, C. Hart. Biological Survey of the San Francisco Mountain Region, Arizona. U. S. Dept. Agric., North Amer., Fauna No. 3, 1890, pl. 1.
} 
It is obvious that the importance of slope exposure lies in the topographic control of the physical factors which form the environment of the plants concerned. It is possible to know, on purely a priori grounds, that two slopes of the same inclination, which lie in opposed positions so that one faces north and the other south, will present to plants two environments differing in almost every essential physical feature. The temperature of the air on two such slopes might be identical as determined by the thermometers of a carefully established meteorological station, but they are distinctly different as they affect the vegetation, for the plants not only receive the direct rays of the sun but receive very different amounts of heat through diurnal terrestrial radiation. This circumstance is of small importance to full-grown trees and large plants, but is of great importance to young plants and seedlings. The soil temperatures of opposed slopes are also widely unlike, even in the presence of the undisturbed cover of natural vegetation. The two opposed slopes would in all likelihood receive the same rainfall, although this is not necessarily the case. An equal amount of rain might effect an equal elevation of the soil moisture on the two slopes, and to the same depth, but the soil evaporation of the south slope would greatly exceed that of the north slope, and a lower moisture would soon prevail in the soil of the former. Greater or less differences may thus be shown to obtain between the opposed slopes with respect to the most vital features of plant environment. Any attempt to explain the importance of slope exposure in determining plant distribution is therefore incomplete unless it takes into account every possible environmental difference between the slopes. Some of these differences are undoubtedly of far greater importance than others, but the question of their relative importance is always one that must be asked with respect to a particular species of plant. To make a thoroughgoing answer as to the importance of slope exposure for a single species is in itself a very great undertaking.

The universal occurrence of a large number of species of plants in the vegetation of the Santa Catalinas, their commonness within their ranges, and the consistency of their distribution with respect to slope exposure, all indicate that there has been ample time in the history of the mountain for all of these species to attain as wide a distribution as it is possible for them to have under existing climatic conditions. It is difficult to conceive of any upward or downward movement being possible for any of the common species of plants, inasmuch as thousands of years have already given an opportunity for such extensions of range. In view of the steep climatic gradient of the mountain it is easy to believe that all of the common species have reached upper and lower limits beyond which their survival is prevented by definite features of the physical environment. The present vertical limit of a species, whether upper or lower, must be looked upon as the average 
point at which some particular feature of its physiological activities is met by some particular environmental condition that is preventive or unduly inhibitory to it. The minor fluctuations of climate, which have their minimal and maximal values within periods that are as brief as the normal life of a perennial plant, are registered in the infrequency of every species as it approaches its distributional limit and in the scattered individuals which lie farthest out from the main area of occurrence. The secular changes of climate which have their maximal and minimal points many centuries apart are registered in slight movements of the limits of species, the marginal region of scattered occurrence being, of course, the first affected by such movements.

The writer has seen no evidence indicating that competition between plants is at any place in the Santa Catalinas responsible for the limitation of any species. There is, of course, competition such as that between seedling pines in heavy stands of 10 to 40 years in age, and such competition as occurs between individuals of the same or different species of herbaceous plants in small areas of moist flood-plain. While competition may thus determine the surviving individuals of a stand of young trees, or may determine the composition of a small community of ephemeral or root perennial plants, it is not responsible for the finding of a plant in one habitat rather than in another, and is not responsible for the exclusion of a species from an area in which it might find favorable conditions.

It is only consistent with our knowledge of the diversified physical requirements of plants that there should be such great diversity in the location of the belts of altitude occupied by different species, and it accords with our knowledge of the distribution of plants in general that these belts should be wider in some cases than in others. It is possible, however, to pick out groups of plants the limits of which correspond roughly with the limits of the Desert, Encinal, and Forest types of vegetation respectively. Even the plants of equatorial regions, in which there is a notable constancy of climate, both daily and annual, are able to endure small ranges of climate, or occasionally to endure changes in individual factors which are many times as great as the normal fluctuations of their native climates. In addition to the fluctuations of climate from month to month or from year to year which must be endured by any plant, there are often even greater differences which must be simultaneously endured by the most remotely separated individuals of the same specific stock. For example, Asclepias tuberosa is found from Maine to Minnesota in the north and from Florida to Texas in the south, and thence sporadically in the mountains westward to Arizona. In view of the prodigious range of this somewhat polymorphous plant it is surprising not to find it reaching a greater elevation than 6,500 feet in the Santa Catalinas. With regard to possible differences in the physiological behavior of the most remotely separated individuals of a plant stock of such wide range, we know little. 
To find a plant growing only on a north slope at 5,000 feet, only on a south slope at 7,000 feet, and on both at 6,000 feet, as is the case with Pinus cembroides, for example, means that there is much in common between the physical conditions on the north slope at 5,000 feet and the south one at 7,000 . If such reversals of habitat in relation to slope were rare it would only be warrantable to state that there were some physical features in common between the opposed slopes, but, as already stated, there are only two common plants (aside from those of the streamways) regarding which a similar statement could not be made. It is obvious, therefore, that if we compare separately the altitudinal gradients of climatic change for the south slopes and for the north slopes of these mountains, the two gradients will be similar in character and will be closely related. Their relationship will consist in the fact that a given intensity or value on one of the gradients will be found on the other at a lower or higher elevation, unless barred by the base or summit of the mountain. In the curve showing the altitudinal gradients of evaporation on north and on south slopes (fig. 14) it will be seen that the rate on the south slope at 6,000 feet is exactly the same as the rate on the north slope at 5,000 feet. The rate on the south slope at 8,000 feet, however, is far less than the rate on the north slope at 7,000 feet. The latter rate is found on south slopes at about 7,300 feet, according to the evidence of the curve. In spite of differences in the pitch of the climatic gradients at different elevations, it is always possible to find a slope which exhibits the same intensity of a given factor as that which has already been found on an opposed slope, but it is necessary to go up or down the mountain from 500 to 1,500 feet to do so. It might be possible to find two spots on opposed slopes in which there was very nearly the same complex of all environmental conditions, although the finding of two slopes with identical ones would be rendered almost impossible by the necessity of seeking these spots at different altitudes.

Even if a series of considerable differences were found between the north slope at 5,000 feet and the south slope at 7,000 feet, on both of which Pinus cembroides is growing, nevertheless such differences would be little greater than those which are met by this species as it grows on both north and south slopes at 6,000 feet or those that exist between the north slopes at 5,000 and 6,000, or the south slopes at 6,000 and 7,000 feet.

The physical factors which underlie the influence of slope exposure are simply a special case, for the most part, of the same factors which cause the altitudinal differentiation of the vegetation of the entire mountain. The only instrumentation carried out with a view to securing a measure of the influence of slope exposure is comprised in the data on soil moisture and on evaporation for north and south exposures at 7 and 5 elevations respectively (see tables 7 and 9 and figs. 10, 13, and 14). 
Neither the data for soil moisture nor those for evaporation show the exact alternation exhibited by the vegetation itself, by virtue of which a given north slope is similar in vegetation to a south slope about 1,000 feet above it, and a given south slope is similar to a north slope about 1,000 feet below it (with the exception of the highest altitudes). The conditions of evaporation found through the range of Pinus cembroides, which has been used as an example of the effects of slope exposure, are indicated in figure 18, where curves are given showing the seasonal march of evaporation on a north slope at 5,000 feet, the average of the evaporation on north and south slopes at 6,000 feet, and the amounts on the south slope at 7,000 feet. These curves follow a course which is parallel and indicate evaporation conditions which are remarkably similar for the lower, central, and upper individuals of this pine, except for the higher rate at 5,000 feet during the arid fore-summer.

The ratios of soil moisture to evaporation at different altitudes have been worked out separately for the north and south exposures at the 6 stations (see table 20). Since these ratios are an

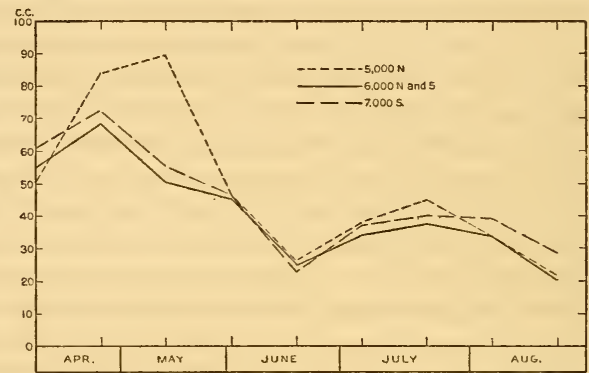

Fig. 18.-Graphs showing seasonal march of rate of evaporation for a north slope at 5,000 feet (dotted line), the average for a north and a south slope at 6,000 feet (solid line), and for a south slope at 7,000 feet (broken line).

expression of the conditions of the arid fore-summer they must be taken as elucidating only those phases of slope exposure which are themselves due to the climate of that season. Any subsidiary influence of temperature in affecting the slope exposure phenomena of vegetation in the Santa Catalinas still awaits a full investigation.

The comparative conditions of the lower, central, and upper habitats of Pinus cembroides may be again investigated in the light of the ratios, which are as follows: North slope at 5,000 feet 21.3, average of north and south slopes at 6,000 feet 24.5 , south slope at 7,000 feet 24.1 . These figures indicate a still more remarkable similarity of the water conditions in the three habitats than the evaporation figures do. To compare a plant of lower range we may take Agave schottii, which encounters conditions expressed by the following ratios: north slope at 4,000 feet 33.1, average of north and south slopes at 5,000 feet 20.6, south slope at 6,000 feet 33.0. These figures fail to show as close agreement, but indicate a close similarity of the water conditions at the lowest and uppermost habitats, and a more favorable set of conditions in the central habitat. To make a similar comparison for a 
plant of higher range than Pinus cembroides we may take Quercus hypoleuca, which ranges through 3,000 feet, with the usual alternation at the top and bottom of its range. The ratios for its habitats are as follows: North slope at 6,000 feet 16.0 , average of north and south slopes at 7,000 feet 16.6, south slope at 8,000 feet 3.9. Here is close agreement of the ratios for the lower and central portions of the range, with a much lower value for the top, indicating that in spite of the ability of Quercus hypoleuca to withstand the conditions expressed by the ratio of 16 , it is likewise capable of withstanding the more favorable water conditions indicated by the ratio of 3.9. Here, in other words, is a typical Encinal plant, accompanied throughout its range by many others, which is able to extend up to an elevation at which the water conditions are much more favorable than they are in the lower part of its range. This is a thing which the Desert plants do not do, and the reason is undoubtedly that the plants of the Desert encounter unfavorable temperature conditions at the same elevations at which they begin to encounter more favorable water conditions, while such a plant as Quercus hypoleuca is capable of withstanding the rigorous temperatures of 8,000 feet and is thereby enabled to range upward into a region of more favorable water conditions.

Allusion has been made to the more pronounced character of the effects of slope exposure at higher elevations. It is of interest in that connection to contrast the ratios of evaporation to soil moisture for similarly located pairs of habitats at low and at high altitudes. For example, the north slope at 4,000 feet has a ratio of 33.1 , the south slope at 6,000 has a value of 33.0 . To carry the comparison up 2,000 feet: the north slope at 6,000 feet has a ratio of 16.0 , the south slope at 8,000 feet has one of 3.9. The greater similarity of the ratios for the two lower habitats is in accord with the evidences from the vegetation (see p. 98), which indicate an altitudinal increase in the potency of slope exposure in the determining of the vegetation.

The fundamental causes differentiating the conditions on opposed slopes are only partly comprised in the evaporation-soil-moisture ratios. The differences of evaporation rate on north and south slopes are largely due to the dry, warm winds which ascend the mountain during the day and partly to the differences of air temperature. The humidity of the air shows only slight differences on opposed slopes. The soil moisture on north slopes is higher than on south ones because of the more direct insolation on south slopes, and because of the higher soil temperature and increased soil evaporation which are due to this. In addition to the differentiating features which are expressed in the ratios, we have the differences of soil temperature, due to the direction of slope, and the differences of air temperature, which are only partially registered in their effect upon the evaporation rate. The increased insolation on slopes as compared with level ground has been worked 
out by Hall, ${ }^{*}$ who shows that the amount of radiant energy reaching a south slope of $45^{\circ}$, with the sun $45^{\circ}$ above the horizon, is 1.4 times as great as that reaching a level piece of ground through an aperture of the same size. It is through this difference, which is still greater between south and north slopes, that the soil is given a higher temperature, that the air is warmed to a higher degree through radiation, and the soil dried more rapidly on all south-facing exposures.

THE RÔLE OF STREAMS AND FLOOD-PLAINS.

In the description of the vegetation of the Santa Catalinas constant allusion has been made to the distinctive plant communities of springs, streams, flood-plains, and arroyos. The contrast between the vegetation of these moist or relatively moist situations and that of the mountain slopes is very striking at the mouths of the larger cañons, and throughout the Desert and Encinal regions. At the higher altitudes, and particularly in the Fir Forest, the moist habitats are not only less striking to the casual observer, but their vegetation actually comprises a great many species which are frequently found away from proximity to streams.

The influence of streams and flood-plains consists, in brief, in bringing components of the upland vegetation of each altitude down along the streamways of the altitudes just below. In this manner the Encinal is traversed by bands of Forest, and the Desert slopes are traversed by bands of Encinal. Furthermore, the streams and springs of the mountain afford the sole habitats for a number of species of aquatic and palustrine plants which do not appear on the upland at any elevation.

The mechanical agencies of gravity, sheet-floods, and stream flow are all capable of aiding in the downward dissemination of the seeds of all mountain plants and these mechanical agencies should assure the occurrence of all mountain plants in all situations at lower altitudes in which they are capable of survival. The number of seeds which are borne down by streams is, of course, enormous, and the number of resulting germinations is probably very large. The number of survivals, however, is controlled by the physical conditions of the new low-altitude habitat, and in a manner to be further considered.

In the discussion of slope exposure no account has been taken of the occurrence of plants along streamways at elevations below their lowest upland occurrence, since the individuals along the arroyos and streams are subjected to a very different set of environic controls from those that determine the location of the upland individuals. In the earlier discussion of the vertical limits of species the streamway occurrences were taken into account.

\footnotetext{
* Hall, H. M. A Botanical Survey of San Jacinto Mountain. Univ. Cal. Pubn. Bot., vol. i, pp. 1-140, 1902.
} 
Among the palustrine plants which occur along streams at 7,000 to 8,000 feet are two species of Juncus and two of Carex which also occur in Sabino Cañon, under the most favorable conditions of moisture supply, at 3,000 to 3,200 feet elevation. The perennial composite Tagetes lemmoni grows along the drier arroyos of the Pine Forest down to 6,000 feet, and is found in lower Sabino Cañon growing along the margin of the stream at 3,200 feet. Other palustrine plants of the Forest region are found from time to time at low elevations along the largest streams, but no others have been observed to become thoroughly established there.

The well-known cosmopolitanism of many aquatic plants would cause us to expect such behavior as is exhibited by Juncus, Carex, and Tagetes in the Santa Catalinas. There are several species of Scirpus and Eryngium, and at least one woody plant (Cephalanthus occidentalis) which range from the Gulf of Mexico across the southwestern boundary of the United States to California. The individuals of these species are subjected to a wide diversity of atmospheric humidities, but are all found under conditions of closely equivalent high soil moisture.

A greater interest attaches, in the present connection, to the cases of low streamside occurrence of plants which grow typically in upland situations. Mention has already been made of the trees of Quercus arizonica and Quercus oblongifolia which grow along the Sabino Creek at 2,800 feet, about 1,200 feet below their lowest occurrence on north slopes. Small plants of Quercus hypoleuca have been found growing in deep shade in the bed of Sabino Cañon at 3,200 feet, which is 2,700 feet below the lowest north slope occurrence of this tree. The firstnamed oaks have descended no further than many other upland plants have done, but the last-named oak shows the most pronounced depression of range that has been detected.

At the mouth of Soldier Cañon, at 3,000 feet, the writer has found one or two individuals each of Dasylirion wheeleri, Mimosa biuncifera, Erythrina coralloides, and Asclepias linifolia. At an elevation of 4,500 feet Dasylirion and Asclepias have begun to appear on slopes of south exposure, and at 5,000 feet Erythrina and Mimosa have also left the arroyos.

At 4,900 feet Ceanothus fendleri is found in the shade of oaks on the flood-plain of Soldier Cañon. It occurs also at 5,300 feet in similar situations at the head of Soldier Cañon, and becomes frequent in the Upper Encinal at 6,000 feet. Similarly Quercus submollis occurs near the constant water at Horse Camp, in Bear Cañon, at 6,100 feet and is of increasing frequence along streams up to 7,200 feet. At that elevation and up to the uppermost limit of Pine Forest it is common on slopes as well as near streams. Robinia neomexicana is found in the flood-plain of Soldier Cañon, near a spring, at 5,300 feet, and first becomes a frequent upland shrub of the Pine Forest at about 7,500 feet. 
It is possible to say, in brief, that the conditions presented by streamsides and flood-plains are such as to depress the ranges of very many plants by as much as 1,000 feet, and of a few plants by amounts as great as 2,000 feet. A depression of as much as 2,700 feet, found in the case of Quercus hypoleuca, does not represent the lowest occurrence of established plants, but rather a chance survival at an elevation in which it would doubtless be impossible for the tree to reach maturity. It can at least be said that throughout the entire length of Sabino Cañon, from the mouth to the Basin, there are no known occurrences of full-grown trees or even shrubs of Quercus hypoleuca.

The extent to which the types of vegetation are depressed in their ranges by the influence of streams and flood-plains is about the same as the average depression of the individual species, that is to say about 1,000 feet. In the case of the occurrence of a closed Encinal in the Basin of Sabino Cañon there has been a depression of 1,500 feet in the limit of this type of vegetation-from 5,500 to 4,000 feet.

Some evidence has already been given leading to the view that the lower limits of all Encinal and Forest plants are determined by those features of the environment which in turn determine the water relation of plants. The facts of the depression of vertical ranges by streams form an additional evidence of this view. So far as concerns atmospheric water-demand the plants growing beside streams are subjected to the same conditions as plants of the nearby upland, but the conditions of water supply are infinitely better for them. In other words, in the ratio of evaporation to soil moisture, $\frac{E}{S M}$, the numerator is the same for stream-side and upland plants and the denominator is greatly increased for the latter, thereby lowering the values for the ratio. In the cases alluded to in which the lowest individuals of a species not only grow in a flood-plain but in the shade of larger vegetation, the plants are under ameliorated conditions with respect to the numerator as well as the denominator in the ratio.

A number of mountain plants are able to survive when taken down to the Desert provided they are placed under conditions in which one or both of the sets of conditions indicated by the above-mentioned ratio are ameliorated. Parthenocissus from 6,000 feet survives with irrigation and partial shade; Echinocereus polyacanthos, from 5,000 to 7,000 feet, survives with occasional irrigations during the arid foresummer; Zauschneria californica, Aquilegia chrysantha, and Sedum stelliforme, all ranging from 5,500 to 7,500 feet, are capable of survival at Tucson from year to year when grown in complete shade with frequent irrigation during the arid fore-summer. These facts point to the ability of such plants to withstand at least the shade temperatures of the Desert, provided the moisture supply of the soil and the moisture requirement of the air are made more nearly like those conditions in the mountain habitats of the plants. Many introduced plants have 
shown themselves incapable of withstanding the atmospheric aridity at Tucson even when grown under the most liberal irrigation. The inability of a plant to pass water on to its transpiring tissues as rapidly as it is withdrawn by a desert atmosphere is undoubtedly a feature common to very many mesophilous plants, and it is apparently the cause which prevents a greater number of palustrine mountain plants from descending the large streamways to the Desert, and it doubtless prevents a lower descent upon the part of many Forest species which reach the flood-plains of the Lower Encinal.

It might be argued that the low occurrence of Forest along the streams of the Encinal and the descent of the Encinal into the Desert Slopes are due to the influence of cold-air drainage rather than to the effects of soil moisture, or that cold-air drainage is at least an important contributory factor. It is difficult to believe that low temperatures, especially those of the winter months, should be a favoring factor for plants which are subjected during the day to just as high temperatures as are the plants of the upland. During the summer months the low nocturnal temperatures might be of some slight importance, but such importance would reside solely in aiding the plant to recover from the excessive transpiration of the preceding day and to build up a reserve of water against the transpiration of the following day, as has been shown by Edith B. Shreve to occur in Parkinsonia microphylla.* The facts that it is the highest diurnal temperatures that are apt to be deleterious to low-ranging mountain plants and that their effect can be only indirectly and slightly offset by the lowest nocturnal temperatures make it appear that cold-air drainage has at least a very minor rôle in this connection as compared with the moisture conditions.

\section{THE RÔLE OF TOPOGRAPHIC RELIEF.}

Each of the leading types of vegetation in the Santa Catalinas reaches the uppermost limit of its occurrence on ridges and high southfacing slopes. This carries the Desert upward into the Encinal and carries the Encinal up into the Forest in such a manner that there is an interdigitation of the vegetistic regions throughout the portions of the mountain in which the topography is mature enough for it to be manifest. This appearance of interdigitation is partly brought about by the influence of streams (which has just been discussed) and is sometimes merged with the influence of slope exposure. These facts do not in the least obscure the high range of each type of vegetation on the narrow ridges which point due south or north and are therefore free from the influence of slope exposure.

On the ridges which lie between the tributaries of Soldier Cañon have been found the highest individuals of all of the characteristic

* Shreve, Edith B. The Daily March of Transpiration in a Desert Perennial. Carnegie Inst. Wash., Pub. 194, 1914. 
species of the Desert (for elevations see page 37 ). On a high ridge tributary to Bear Cañon have been found the highest individuals of Opuntia sp., the highest species of that genus on the mountain, and Mamillaria grahami, the highest-ranging plant of the Desert. The individuals which most nearly approach these highest stations for Opuntia and Mamillaria have been found on south exposures about 600 feet lower, in the Bear Cañon drainage.

On an exposed ridge, with a considerable inclination to the south, at 7,800 feet are found the highest individuals of Pinus cembroides, Juniperus pachyphloea (with one known exception), Yucca schottii, Echinocereus polyacanthus, and Arctostaphylos pungens. In this station the influences of slope exposure and of topographic relief are combined, thereby bringing about the pronounced conditions that are expressed in the highest occurrence of 5 species of the Upper Encinal. On the ridges above Marshall Gulch are found the highest occurrences of Quercus hypoleuca and Quercus reticulata, both of which forms extend further down the south faces of these east-and-west ridges than they do down the north faces.

When Desert plants are found on the ridges of the Encinal region they fail to appear on the south-facing slopes just below these ridges. When the plants of the Encinal are found at their highest locations on ridges of the Forest Region they are also absent on the south-facing slopes just below the ridges. This does not appear to be the case with respect to the highest occurrences of plants which are believed to have their true climatic limit just below the summit of Mount Lemmon, such as Quercus hypoleuca and Quercus reticulata.

The extent by which the highest individuals on ridges exceed the highest individuals on south slopes is never more than 500 to 600 feet, except in the case of Pinus cembroides, in which it is about 700 feet. Opuntia sp. and Mamillaria grahami, which have their upper limit in the vicinity of 7,000 feet, agree in this respect with Opuntia versicolor, Echinocactus wislizeni, and Fouquieria splendens, which have their limit in the vicinity of 5,500 feet.

Perhaps the most common explanation of the highest occurrence of species on ridges is that the soil is driest in such situations and therefore offers to plants from lower elevations a habitat more like that in which they are abundant. The principal objection to such an explanation is the unquestionable fact that a somewhat more moist soil is not inimical to the plants of the Desert nor to the plants of the Encinal. Neither is there a sufficient difference between the soil moisture at the bottom of a slope and on the ridge at the top of the slope, in the arid seasons, to cause a differentiation of the vegetation.

The explanation of the phenomenon may be sought partly in the existence of cold-air drainage, which is at least responsible for the absence of Desert and Encinal plants from the bottoms of cañons at 
the highest elevations to which they attain. The streams of cold air are not more than 75 to 100 feet deep, however, and can not, therefore be functional in preventing the occurrence of plants on the middle and upper slopes of cañons. An apparently valid explanation of the high occurrences on ridges is in accordance with the theory already mentioned, that the upper limits of the Desert species, and possibly of the Encinal species also, are set by winter temperature conditions. The ridges are obviously the localities which receive the fullest and longest insolation on the short winter days with low sun. This circumstance would not only warm the plants themselves but would warm the soil and rocks in a manner such as to lessen the severity of the coldest nights. With the pronounced low temperatures in the cañons, due to cold-air drainage, and with the favorable conditions of the ridges for a pre-warming of both plant and habitat, it may be expected that there will be great differences between the vertical limits of species in cañon bottoms and on ridges.

\section{GENERAL CONCLUSIONS.}

The desert mountain ranges of the southwestern United States stand in the midst of a region which presents severe conditions for plants. The relative richness of the vegetation in this region is due chiefly to the occurrence of two yearly seasons of rainfall. The entire annual vegetational behavior is related primarily to the moisture seasons and much less pronouncedly to the thermal seasons. The perennial plants lead an existence which permits of rapid growth during the warm humid season, together with an extremely low ebb of activity during the arid seasons, and with the possible loss through drought-death of much of the growth that has just taken place.

The severe conditions of the desert environment cause the vegetation to exhibit a high degree of sensitiveness to slight topographic and edaphic differences. Wherever the character of the soil or the topographic location is such as to present a degree of soil moisture slightly above that of the general surroundings, or as to maintain it for a longer time in the periods of extreme aridity; or in whatever locations plants are protected from the most extreme conditions of transpiration-in such places are to be found heavier stands of vegetation or else particular species of plants.

The higher mountains of the desert region exhibit strong gradients of change in climate and in vegetation. Both of these gradients are much more pronounced than those of mountains of equal elevation in more humid regions. They lead from arid to humid, or at least semi-humid, conditions of moisture, and from sub-tropical to temperate conditions of temperature; from low, open microphyllous and succulent desert, through a sclerophyllous semi-forest to heavy coniferous forest. 
The sensitiveness which desert vegetation exhibits to slight environmental differences is even more pronounced with respect to the climatic gradients of the mountains. Throughout a vertical range of 6,000 feet there is not only a very striking gradient of vegetation, but a very nice adjustment of vegetation to the physical conditions. In the Desert and Encinal regions, and to a great extent in the Forest as well, this is chiefly an adjustment of plant to environment and scarcely at all an adjustment of plant to plant. Every juvenile individual in the open Desert and Encinal regions is a pioneer, and on reaching maturity this individual is part of an ultimate stable community.

The principal features of altitudinal climatic change are: the shortening of the frostless season, the lowering of the daily curve of temperature throughout the frostless season, the increasing of the intensity and duration of all critical phases of low temperature during the frost season, the shortening of the arid fore-summer (the critical season of aridity), the increasing of precipitation and therefore of soil moisture, and the decreasing of evaporation.

On a mountain having the form of a smooth cone it would be possible to observe the ideal manner in which these climatic gradients would collectively control the vertical distribution of the vegetation. The occurrence in nature of irregularities of relief is responsible, however, for local departures from the ideal vertical gradients of climate and also from the ideal altitudinal distribution of vegetation which would be anticipated on a geometrically constructed mountain. It is possible, nevertheless, to correlate the climatic and vegetational gradients in spite of the local irregularities of each of them, and in fact the study of these departures from the ideal has aided in the interpretation of the correlations.

The vertical distribution of vegetation on the Santa Catalina Mountains has been found to be due to the interaction of two sets of controls which are nearly distinct. One of these controls has its seat in the moisture conditions, the other in the temperature conditions. The temperature control has been studied experimentally only with respect to three species of plants, but it is believed on this evidence (as well as the evidence of the departures from the normal gradient of vegetation, correlated with instrumentation) to be the control which limits the upward distribution of the Desert species and perhaps of some species of the Encinal. The moisture control has not been studied experimentally in connection with the present investigation, but its operation is well known, and the instrumental study of soil moisture and evaporation at successive altitudes, with due attention to the departures from the normal gradient of vegetation, has indicated that the ratio of the latter factor to the former affords a concise expression of the control which limits the downward distribution of Forest and Encinal plants. 
The principal departures of the vegetation from the ideal gradient that would be found on a geometrical cone are expressed in the irregularity of the upper or lower limits of vegetations or of individual species as observed in different habitats. The chief departure is that due to slope exposure, by virtue of which the vegetation of north-facing and south-facing slopes at the same elevation shows striking differences. A second departure is that due to the influence of streams and the high moisture content of the soil of arroyos and flood-plains, by reason of which the plants of all altitudes are carried below their normal lowest occurrences on slopes. Another departure is due to the influence of ridges, on which the plants of all elevations (and particularly those of the Desert) find their highest occurrences. These departures seldom result in the occurrence of distinctive plant communities, but are operative rather in the carrying of the usual and widespread communities into elevations at which they are exceptional. The effect of slope exposure is to carry the normal vegetation of a given elevation both up and down the mountain, so that its lowest occurrences are on north slopes and its highest on south slopes. The effect of streamways is to carry either the normal or the streamside vegetation down the mountain, so that the extreme lowest occurrences of almost all Encinal and Forest plants may be sought along the streamways. The effect of ridges is to carry the vegetation (or more particularly individual species and small groups of species) $u p$ the mountain, so that all highest occurrences of Desert and Encinal species are to be found on narrow ridges-the highest occurrences of Forest plants are not reached on the Santa Catalina Mountains, and they are controlled by a very dissimilar group of factors.

It is impossible to study the distribution of vegetation in a region where pronounced differences may be found within short distances without being impressed with the independence which each species exhibits in its allocation. Plants which are associated on the Lower Desert Slopes, for example, range to very different maximum altitudes, and plants which are associated in the Upper Encinal are found to be in part at the upper edges of their ranges, in part at the lower edges, and also in part rather closely restricted to that region. It is nowhere possible to pick out a group of plants which may be thought of as associates without being able to find other localities in which the association has been dissolved. Certain plants may be thought of as having closely identical physical requirements because of their associated occurrence in the same spot. Nevertheless, the fact that the vertical ranges and habitat characteristics of these species will reveal more or less pronounced differences goes to show that each of them has survived in a particular section of the climatic gradient. It is true in the Santa Catalina Mountains, as it is true in all other places, that the associated members of a plant community are not able to follow each 
other to a common geographical and habital limit. The physical requirements of plants are so varied and so elastic that the composition of a series of communities occupying similar habitats in widely separated places shows the constant overlapping of the ranges of individual species which is due to the physiological inequivalence of these species.

It is particularly true of the plant communities of arid and semiarid regions that the most closely associated individuals are not alike in their life requirements, and this is true to a less pronounced extent in all plant communities. The members of the many diverse biological types, or growth forms, which are found together in Desert and Encinal find their soil water at different levels, procure it at different seasons, and lose it through dissimilar foliar organs, at the same time that they react differently to the same temperature conditions. In brief, these associated plants are not living in the same climate but are living in different sections of the same climate, the demarcation of these sections being either temporal or spatial.

The use of the physical characteristics of the habitat as a criterion in the definition of a plant community does something to give a greater rigidity and a wider applicability to the definition. On the other hand it confuses cause with effect and makes it impossible to investigate the relation of physical conditions to a community defined in that manner without reopening the whole question as to the nature and identity of the community. There is much strong logic to support the view that all necessary definitions and classifications of vegetation should be made on the basis of the vegetation alone. When units of vegetation are thus defined they lend themselves to the further study of their life requirements, and it is such study-applied to individual species as well as to vegetation-that affords the most promising and important field for ecological activity.

The distribution of vegetation in the Santa Catalina Mountains is strongly controlled by a steep climatic gradient; the vegetation itself is diversified in its display of growth forms; and the secular changes of vegetation due to physiographic phenomena, and to the reaction of the plant upon its habitat, are in almost complete abeyance. These circumstances have made it possible to give a delineation of the vegetation upon purely vegetational characteristics, without regard to the secular changes which are taking place in very restricted areas, and with particular emphasis upon the individualism of behavior among the characteristic species. The same circumstances have also made it possible to lay side by side the facts respecting the vegetational gradient and those respecting the climatic gradient in such manner as to reveal the correlations between the two and to indicate some of the physical controls which operate in the limitation of the activities and of the ranges of species and of vegetations. 


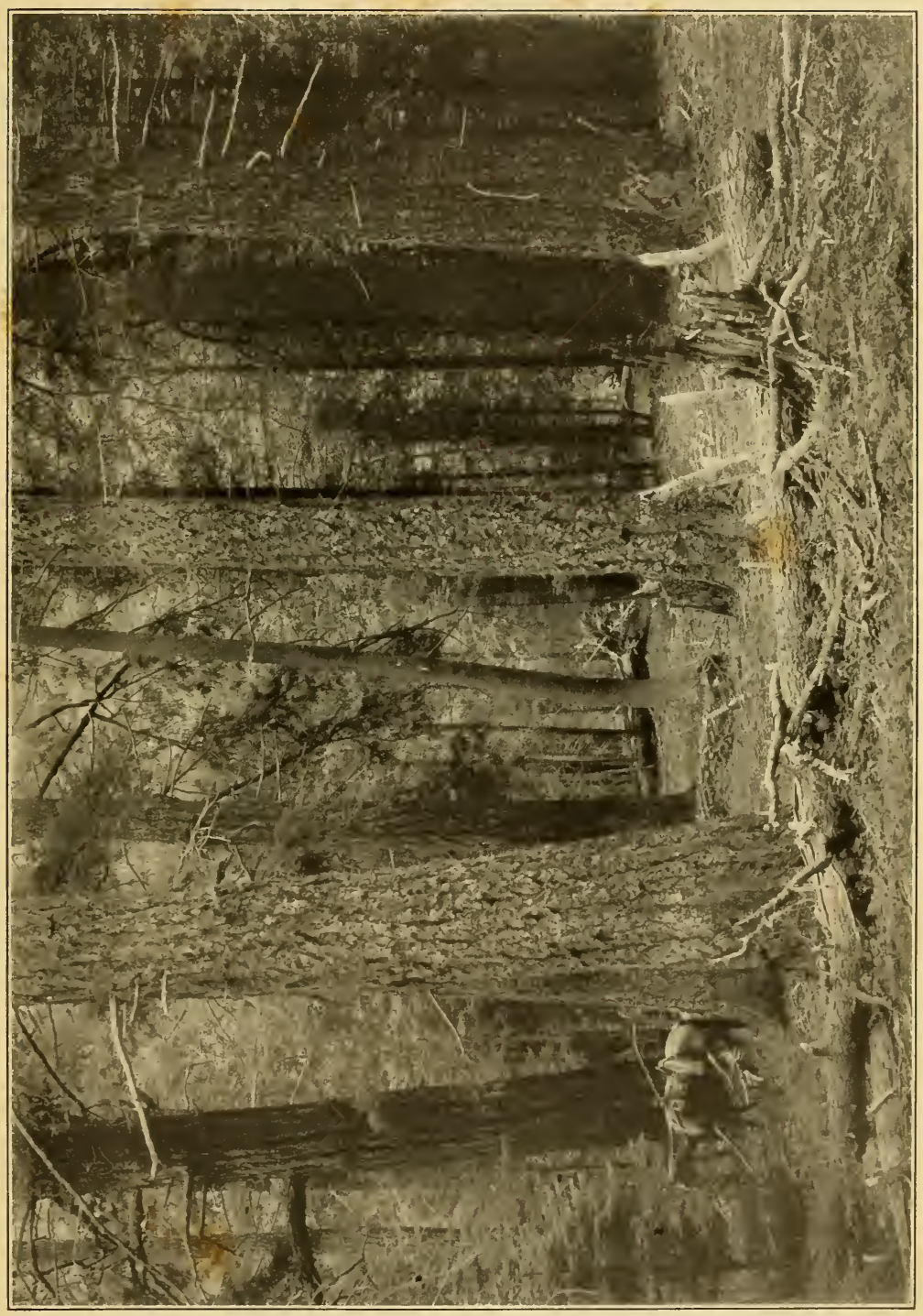





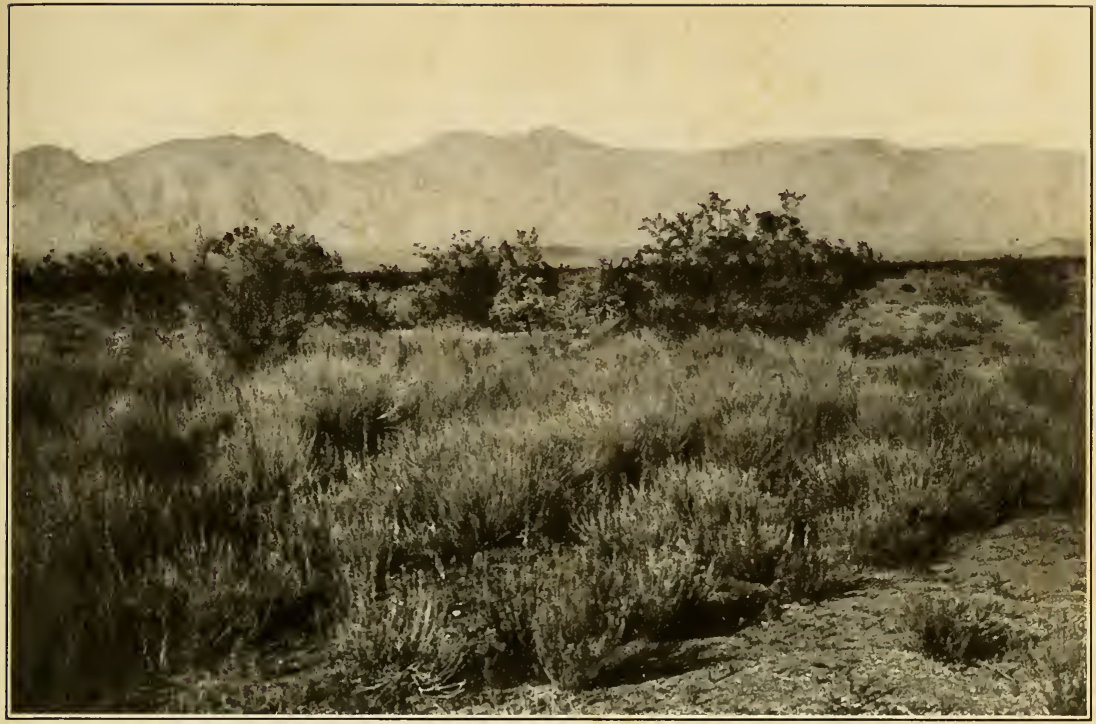

A. South face of Santa Catalina Mountains viewed 7 miles from their base. Mount Lemmon is on right center. In forcground is bajada vegetation of Covillea tridentata, Opuntia spinosior, and Isocoma hartwegi.

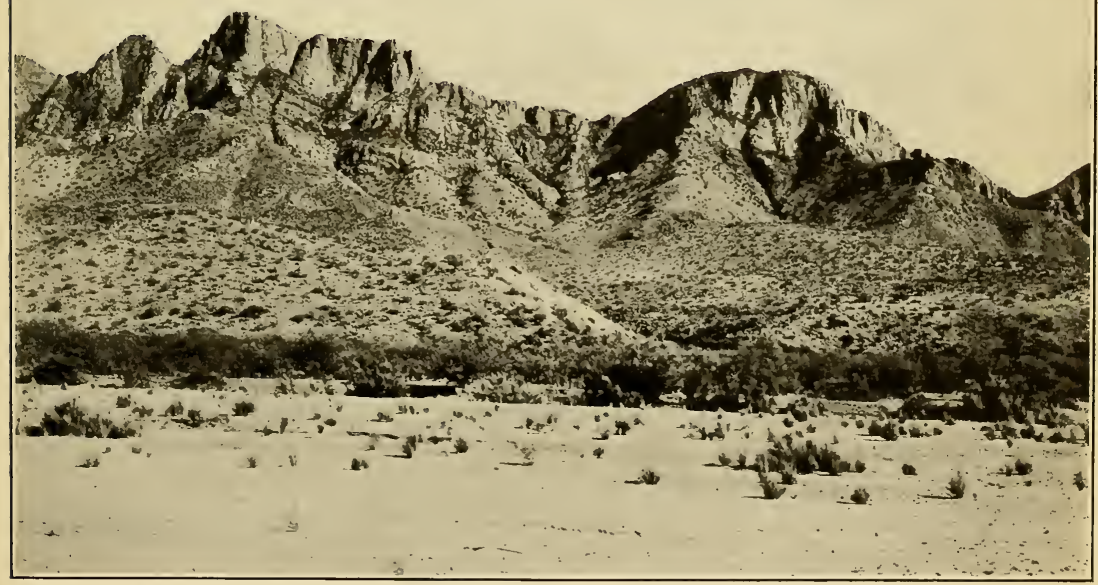

B. Extreme southwestern ridge of Santa Catalinas viewed from the north. In foreground is the bed of the Canada del Oro, with individuals of Hymenoclea monogyra and a marginal fringe of Prosopis velutina and Chilopsis linearis. 



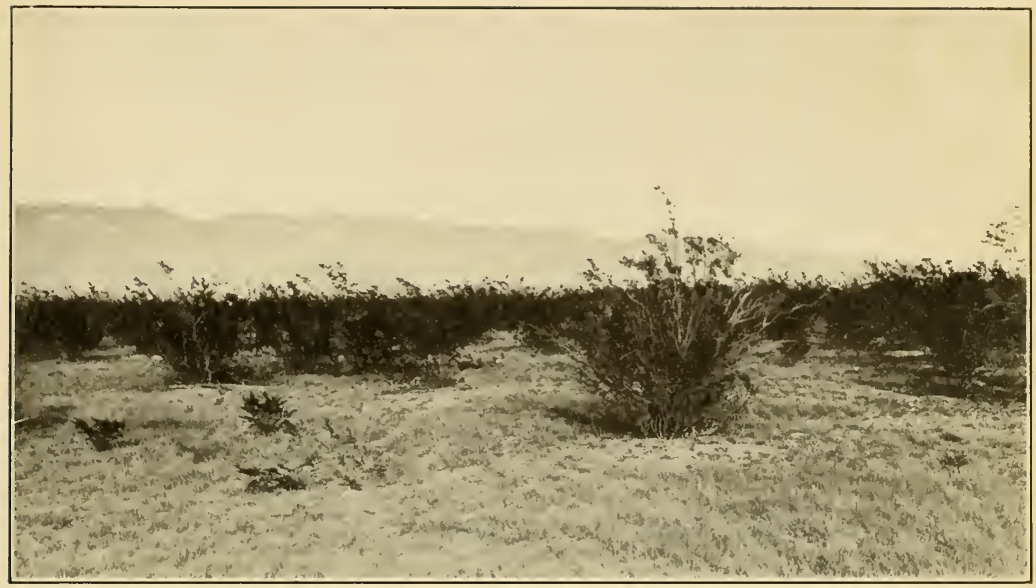

A. Typieal Low Bajada, with pure stand of Covillea tridentata and summer carpet of Bouteloua aristidoides.

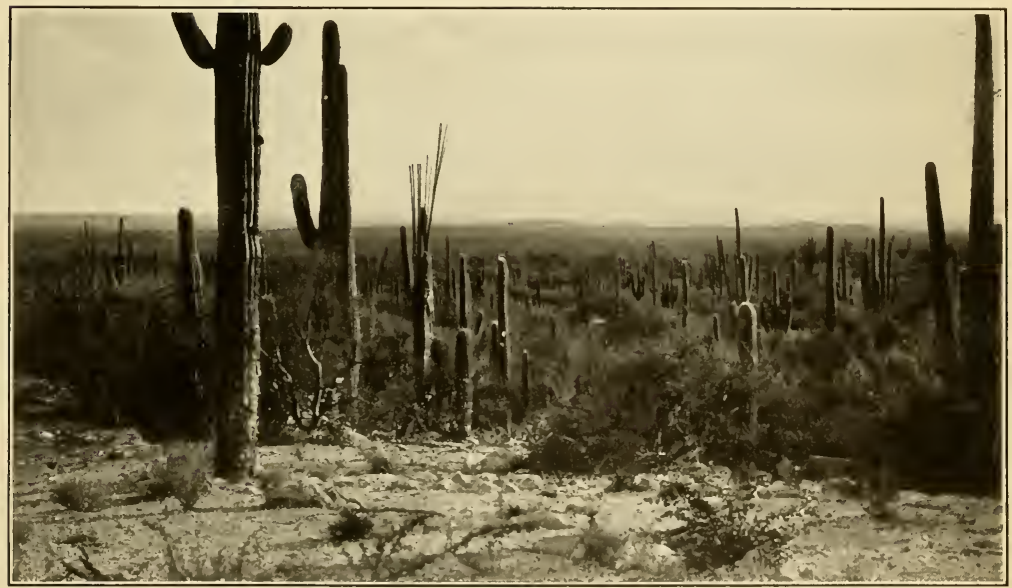

B. Looking southwest from Lpper Bajada near mouth of Soldier ('añon. In the arroyo in foreground are Carnegica gigantea, Parkinsonia mierophylla, Acacia greggii, and Fouquieria splendens. Distant hills are reliet toes of ancient bajadas. 
. 

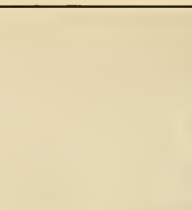

\section{No}
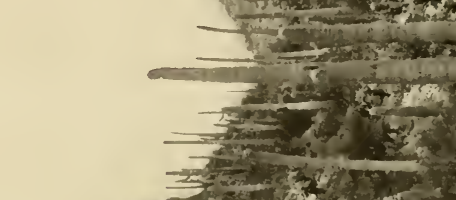

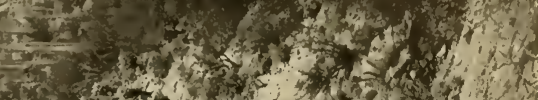

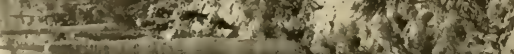

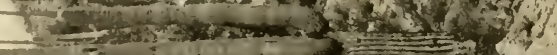

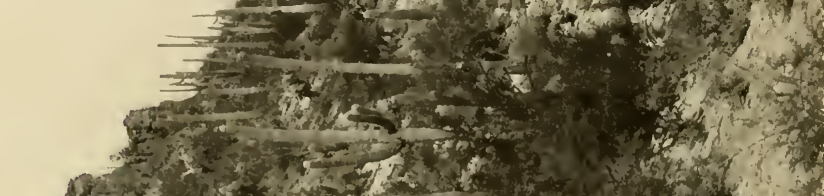
1.t.

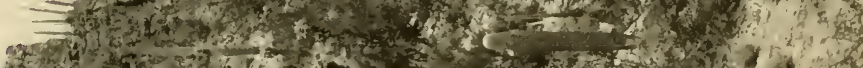

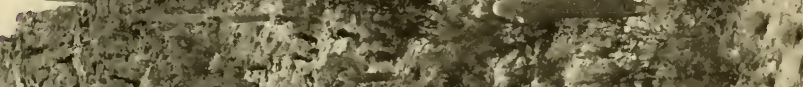

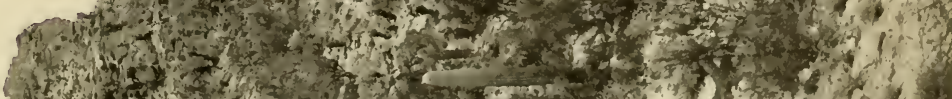

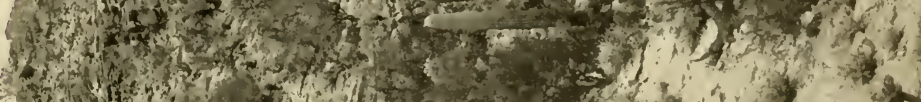

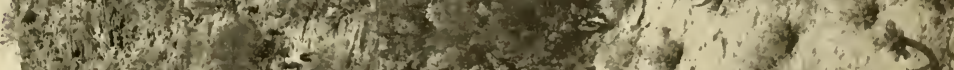

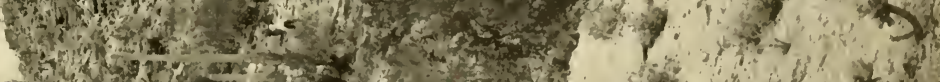

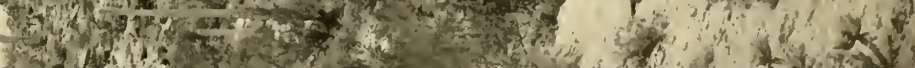

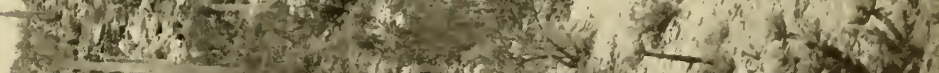

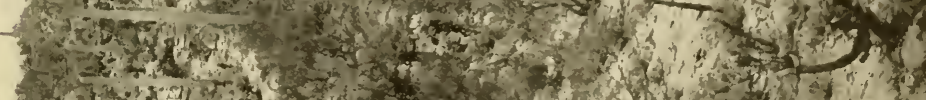

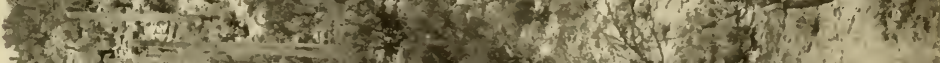

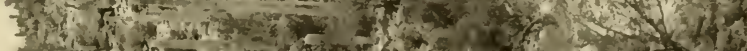
If

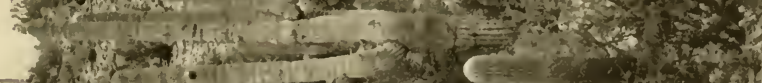
1
2

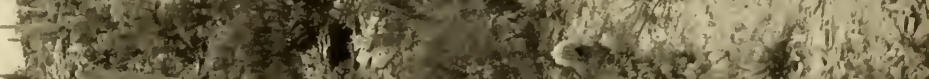

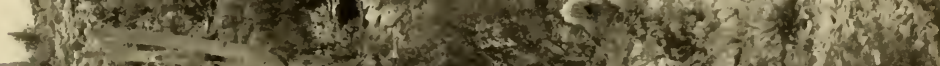

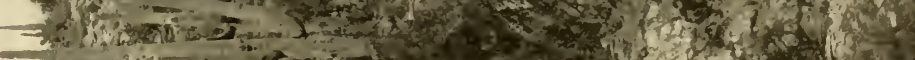

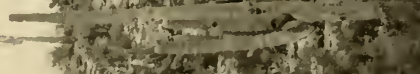

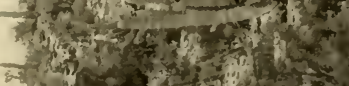

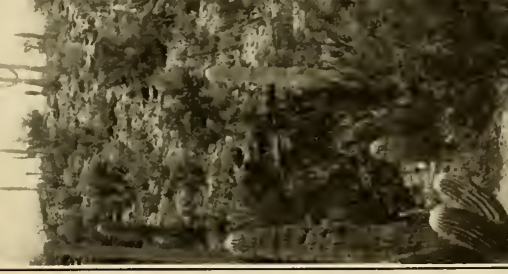

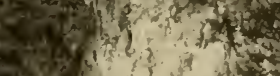

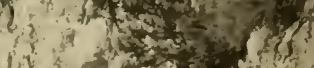

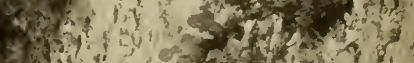

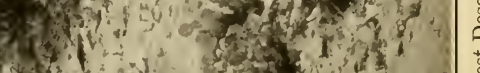
(5)

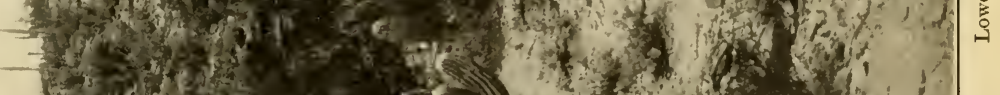





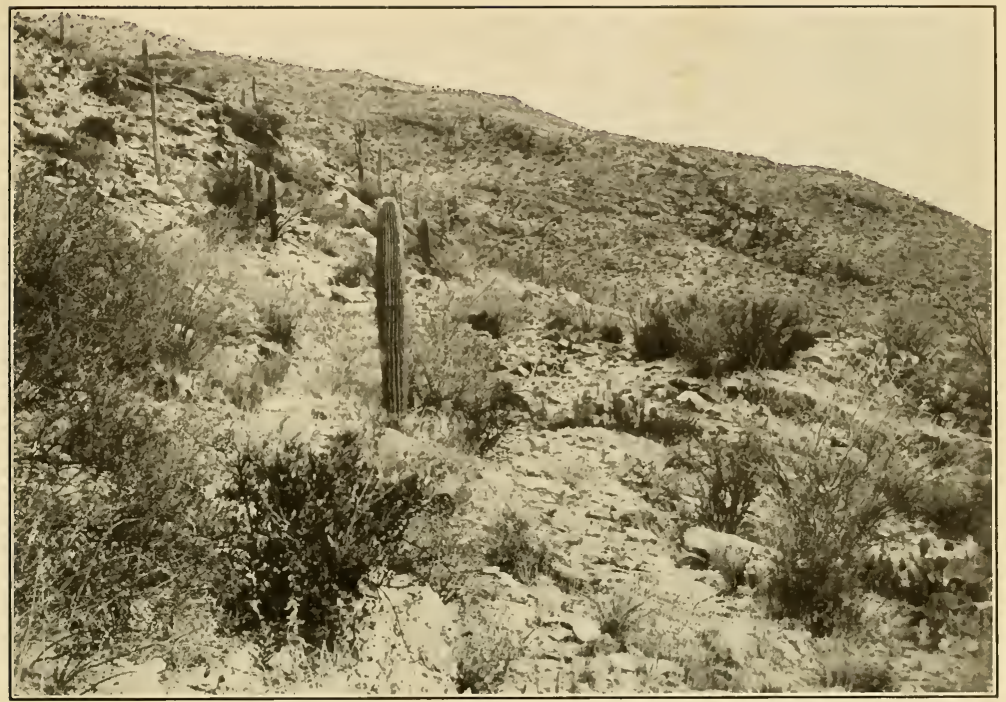

A. Desert Slopes near mouth of Pina Canon. In foreground, from the left are Parkinsonia microphy!la, Simmondsia californica, Carnegiea gigantea, Opuntia toumeyi, and Lycium berlandieri.

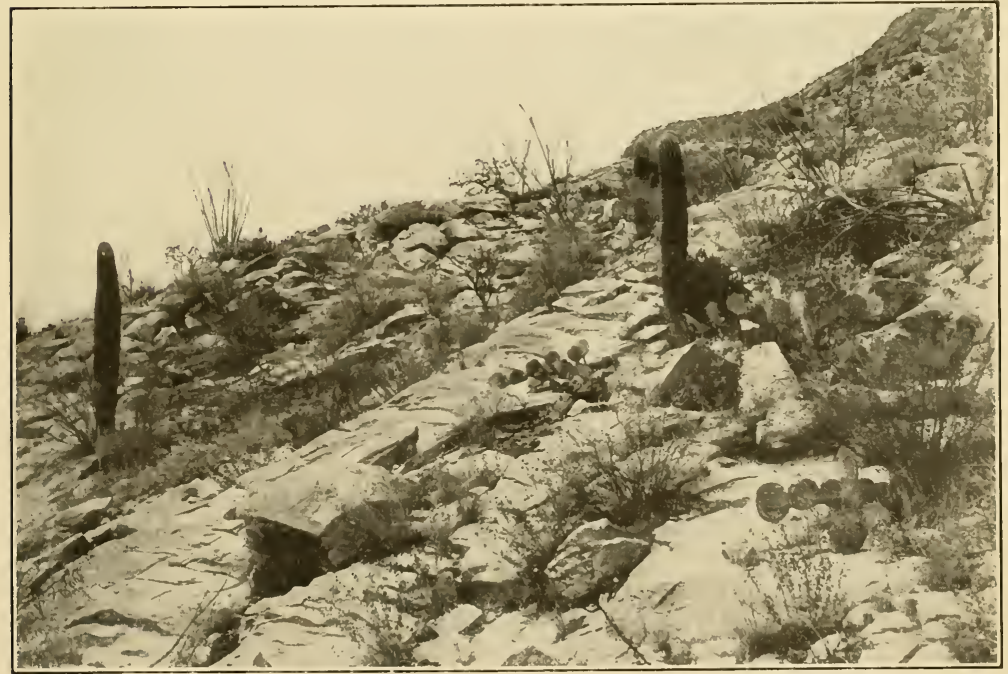

B. Roeky Desert Slopes in same vicinity as A. Against the sky are Fouquicria splendens, Prosopis relutina, and Momisia. pallida; in foreground Sphreralcea pedata, Lippia wrighiii, and Opuntia engelmanni. 




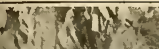
X. H.

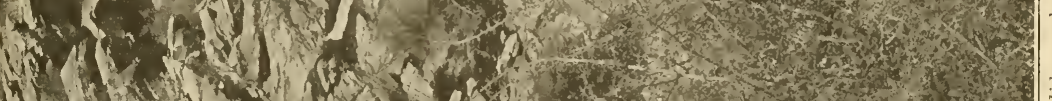

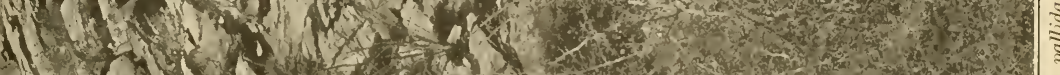
(1)

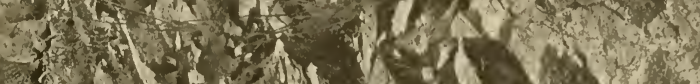

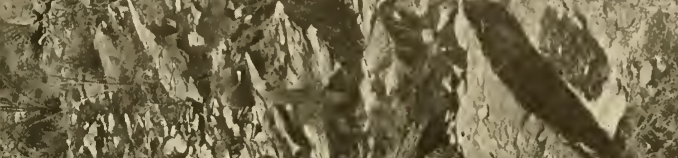

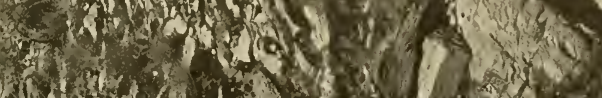

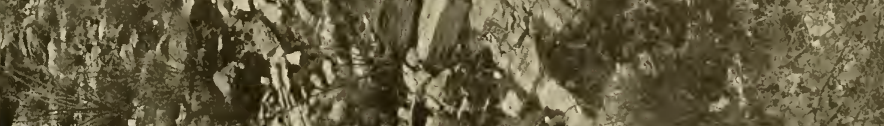

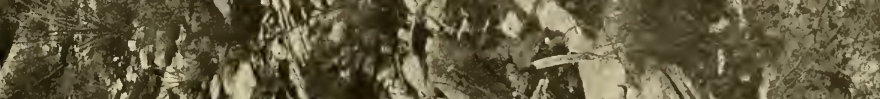

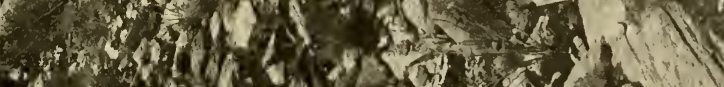

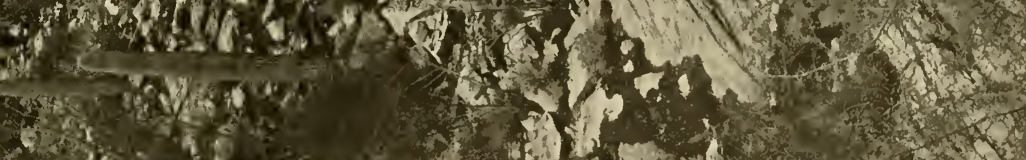

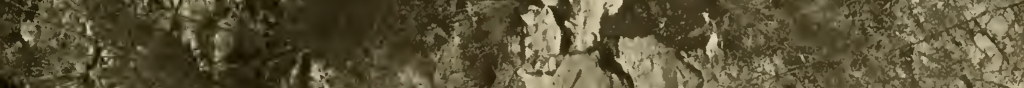
V. $(1,1)$

(o. $)$ (n) E.

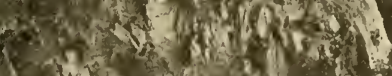
1. 1 .

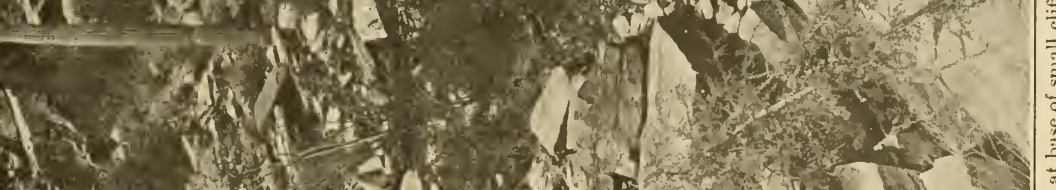
3. (n) $x^{3}$ in (x)

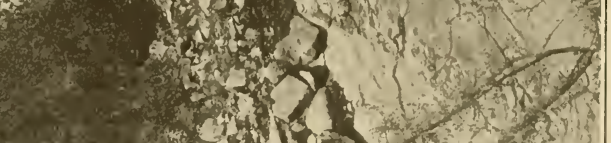

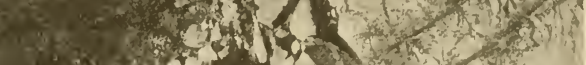

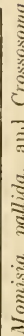





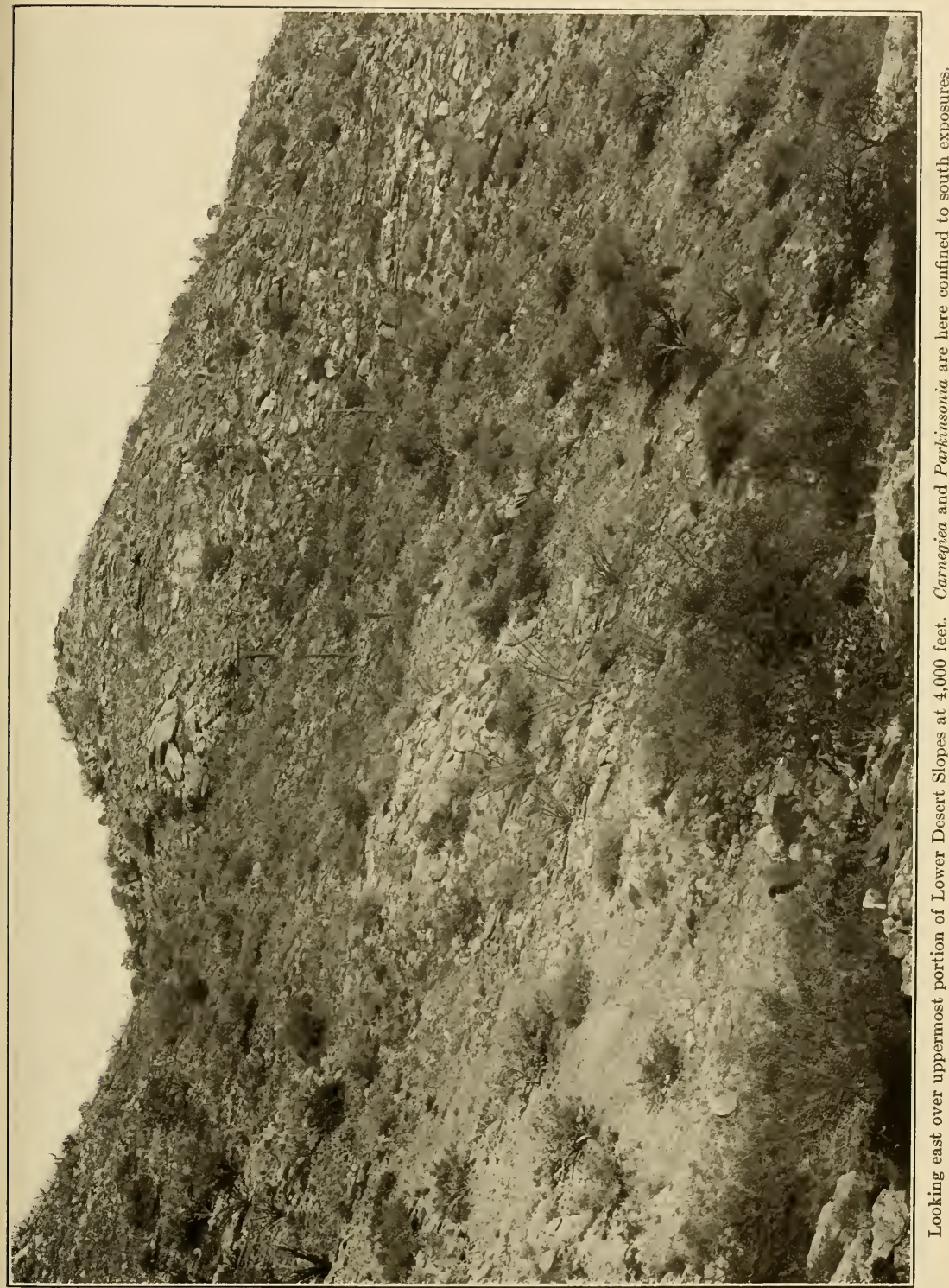






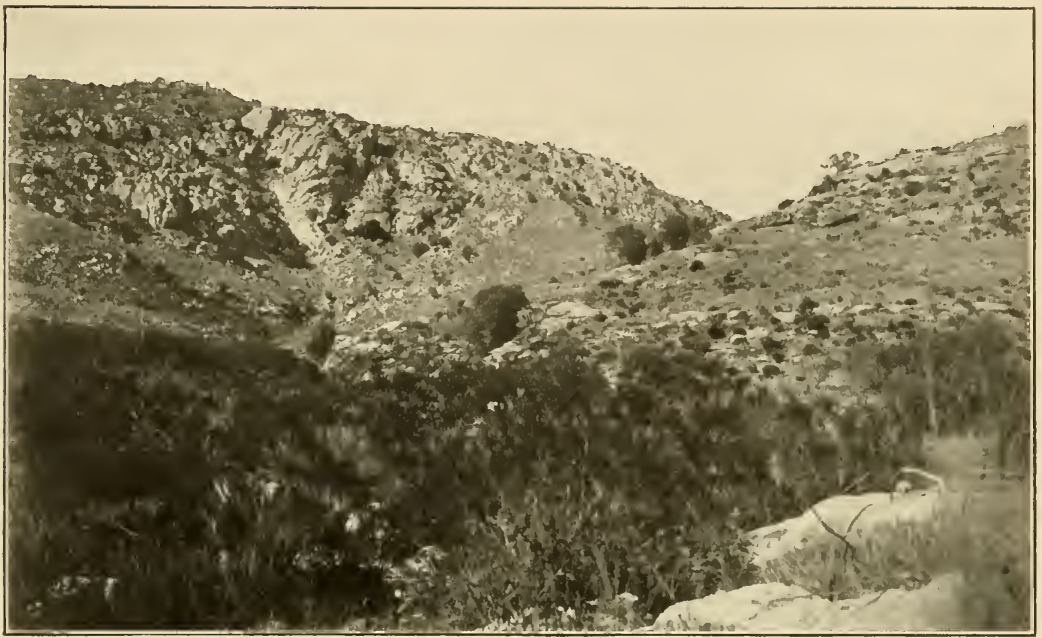

A. Flood-plain of Soldier Cañon at 4,200 feet. The predominant plant is Baccharis sarothroides.

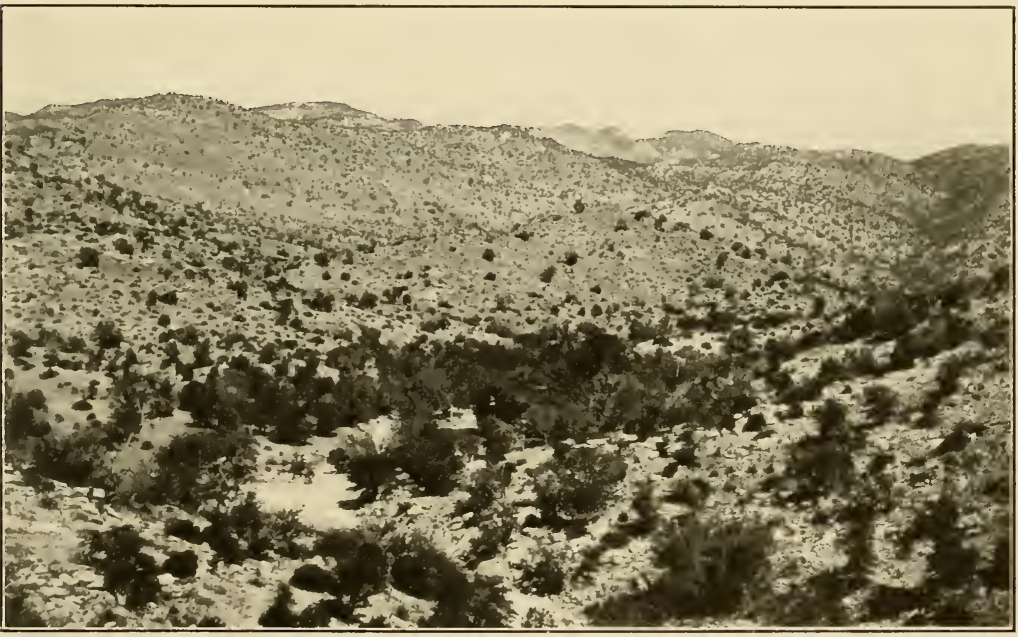

B. Lower Slopes and Flood-plain of Soldier Cañon at 4,900 feet. The predominant trees are Quercus emoryi and Juniperus pachyphloea, the shrubs Arctostaphylos pungens and Garrya wrightii. 



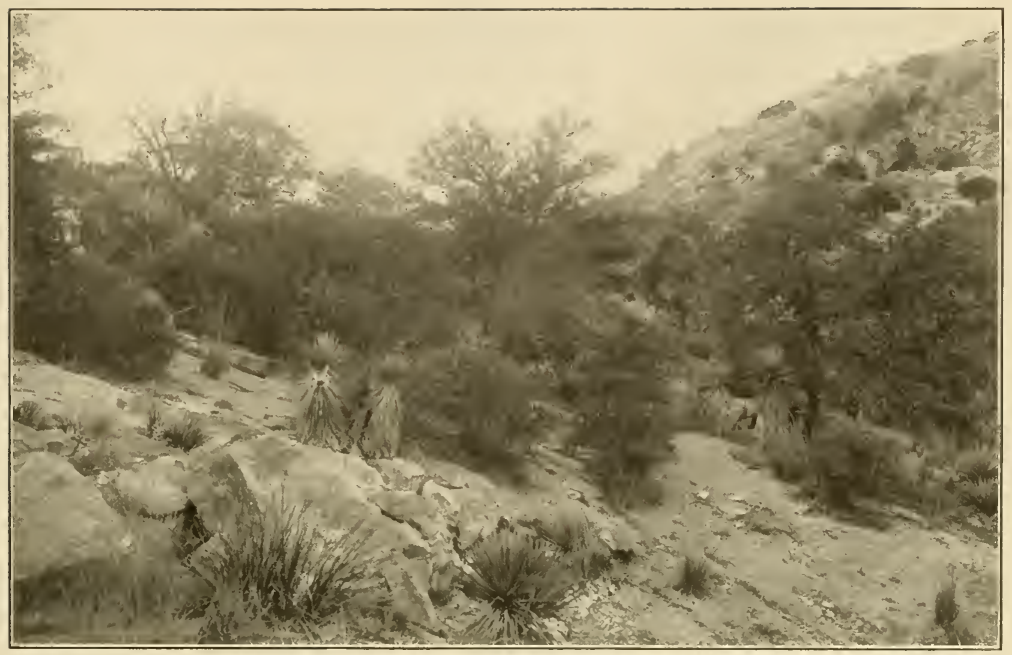

A. Encinal in Soldier Cañon at 5,000 feet, with Quercus emoryi, Juniperus pachyphloca, Garrya wrijhtiz, Yucca marrocarpa, and Nolina microcarpa. At lower left is Bouteloua rothrockii.

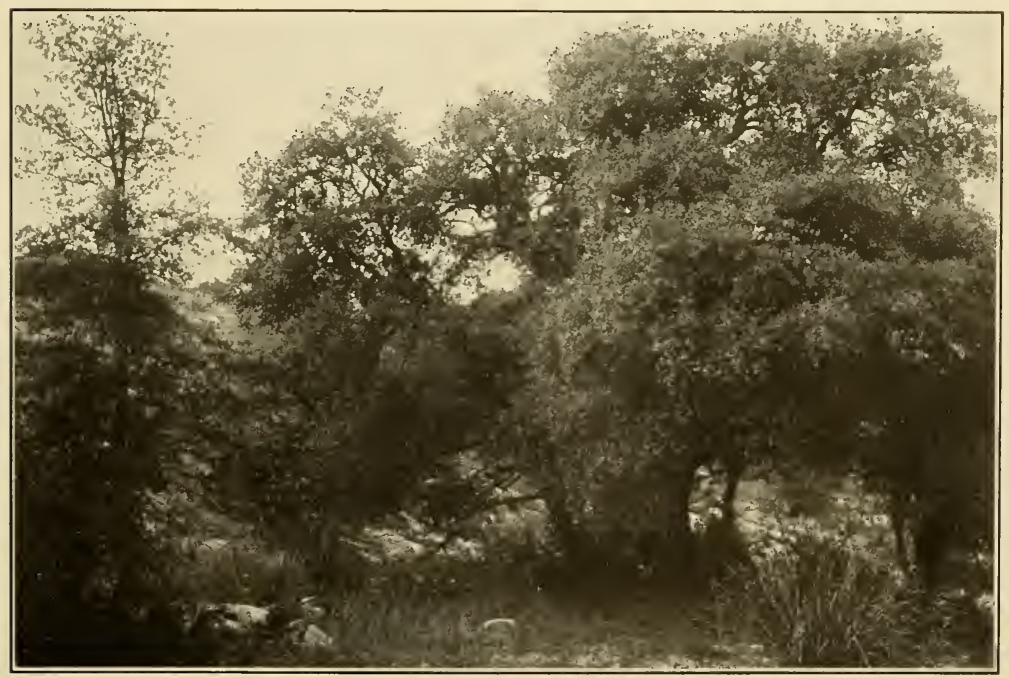

B. Quercusoblongifolia in Flood-plain of Soldier Cañon. At left Qucrcus emoryi, at right Nolina microcarpa. 



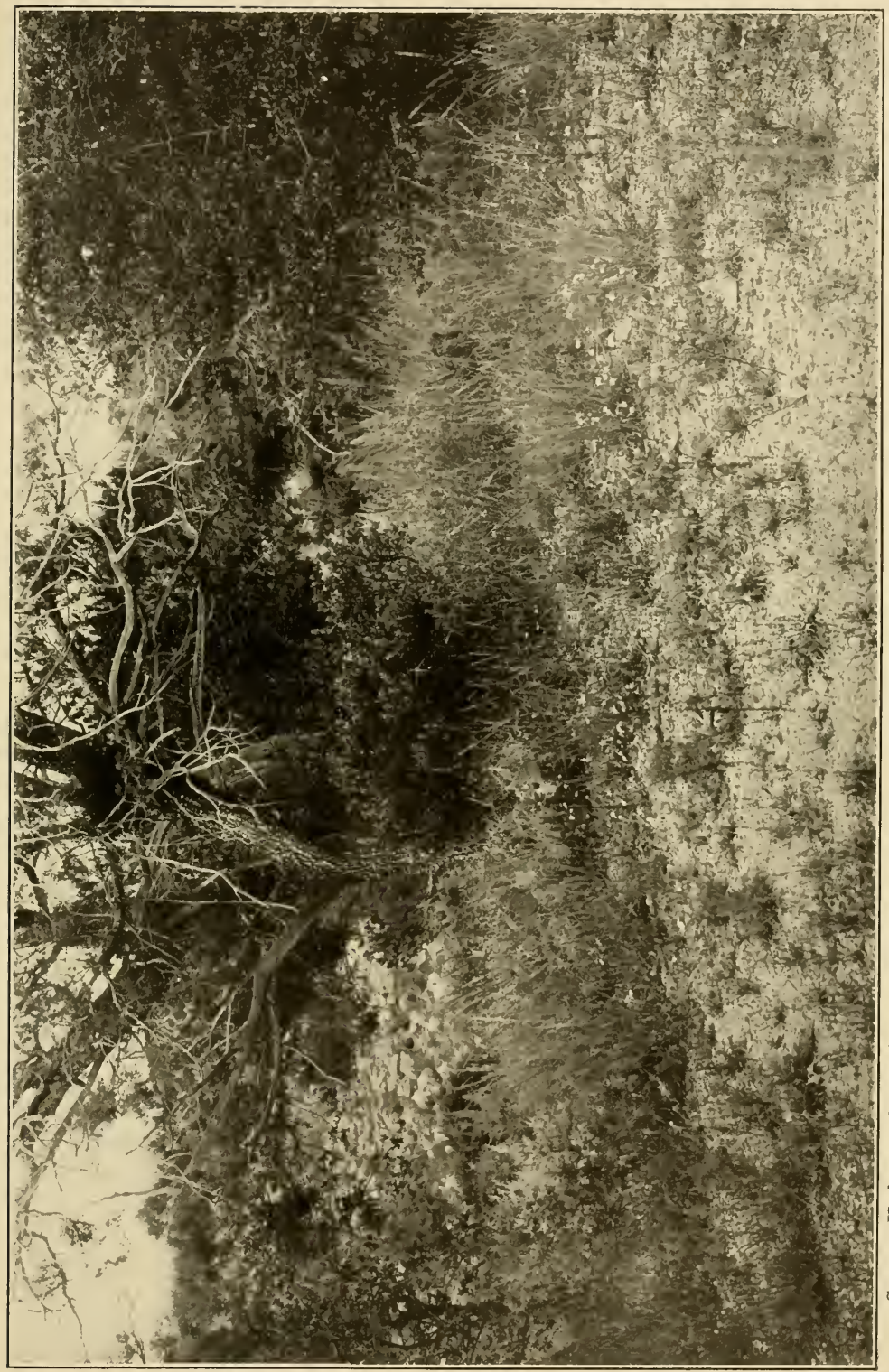





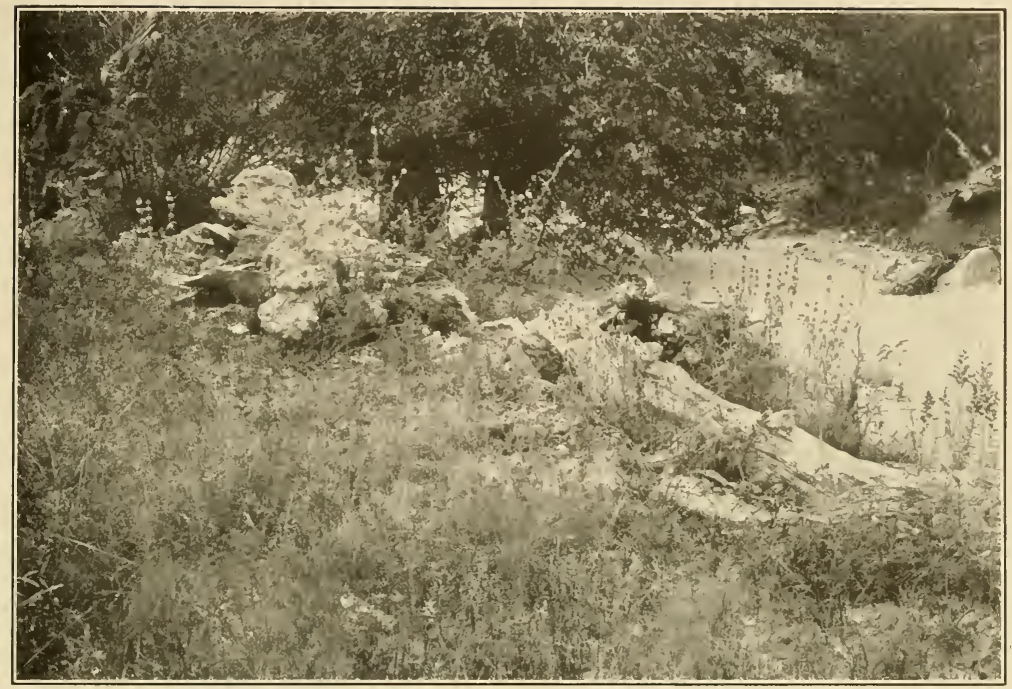

A. Heary Carpet of Summer Herbaceous Vegetation on a Flood-plain at 5.000 feet. Solidago sparsifora var. subcinerea, Monarda pectinata, Crotalaria lupulina, and spharalcea sp.

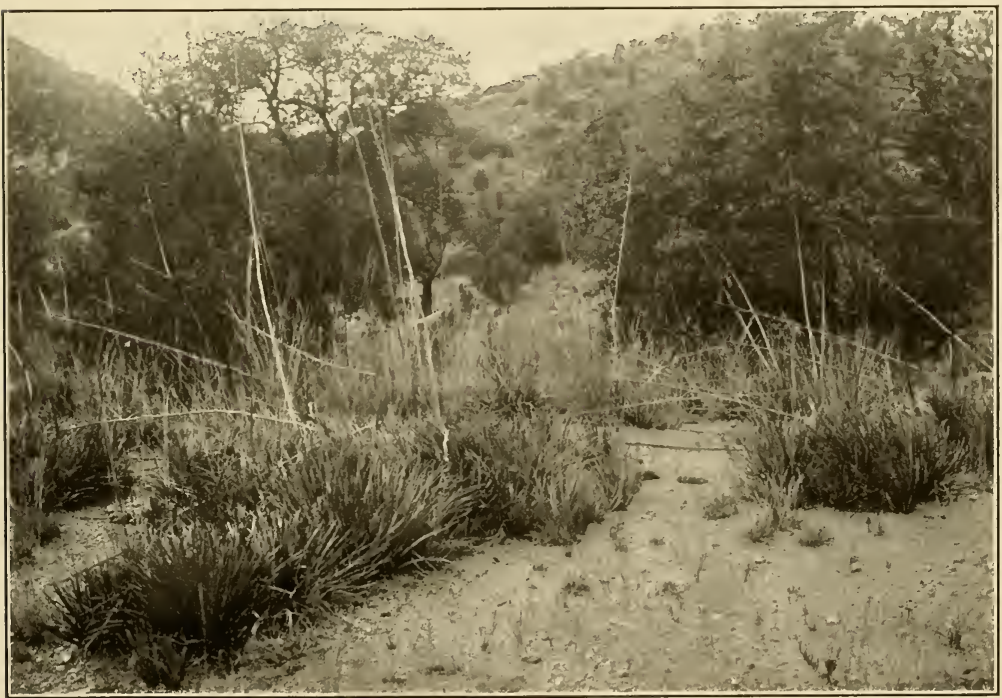

B. Agare schottii in the Lower Encinal. Extensive areas between 4,200 and 5,400 feet are covered by this plant. 



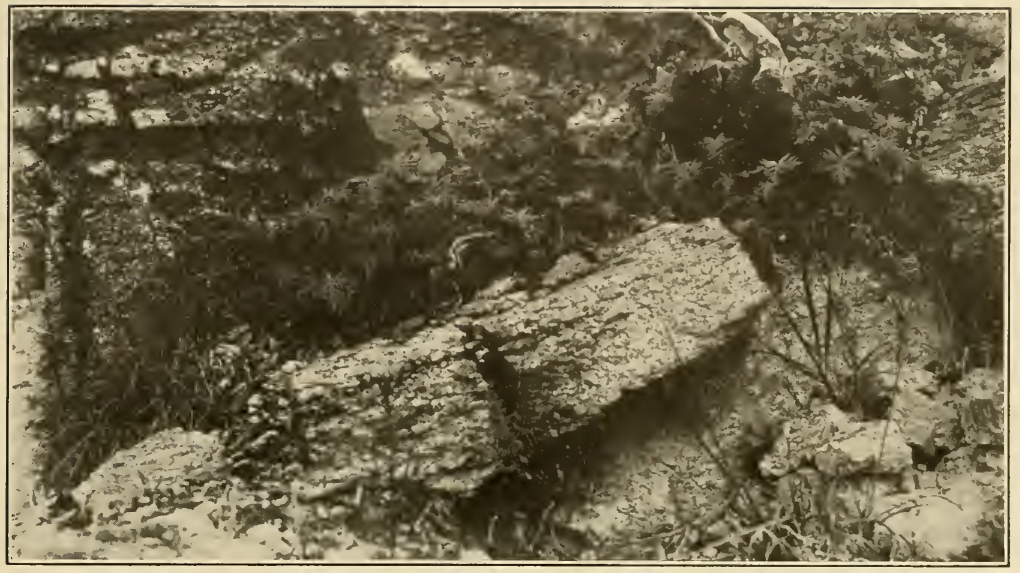

A. Gymnopteris hispida occupying a ledge of rock in the Lower Encinal at 5,200 feet.

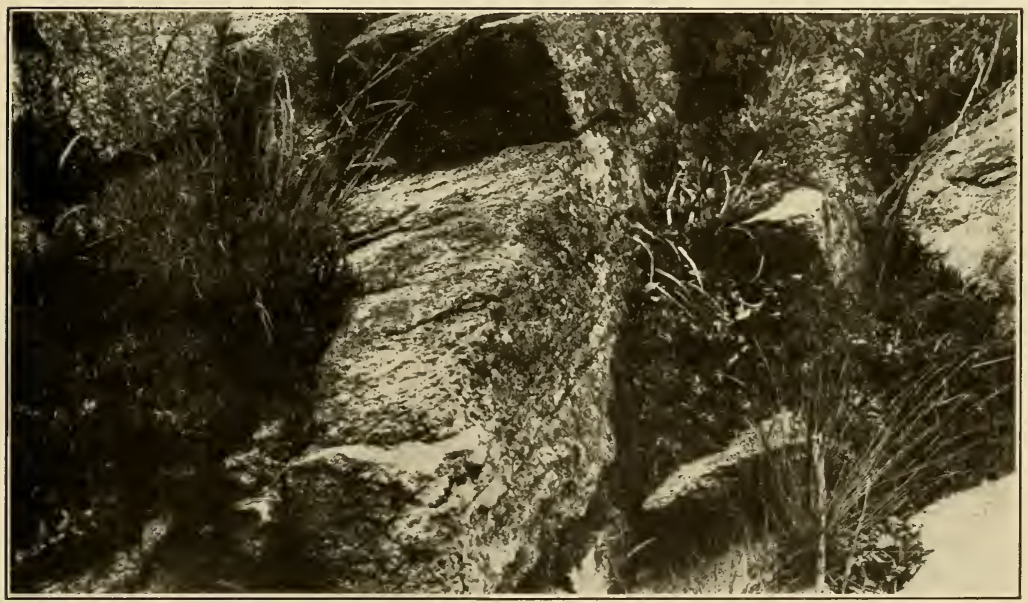

B. Mats of Selaginella sp. among rocks at 5,300 feet. 



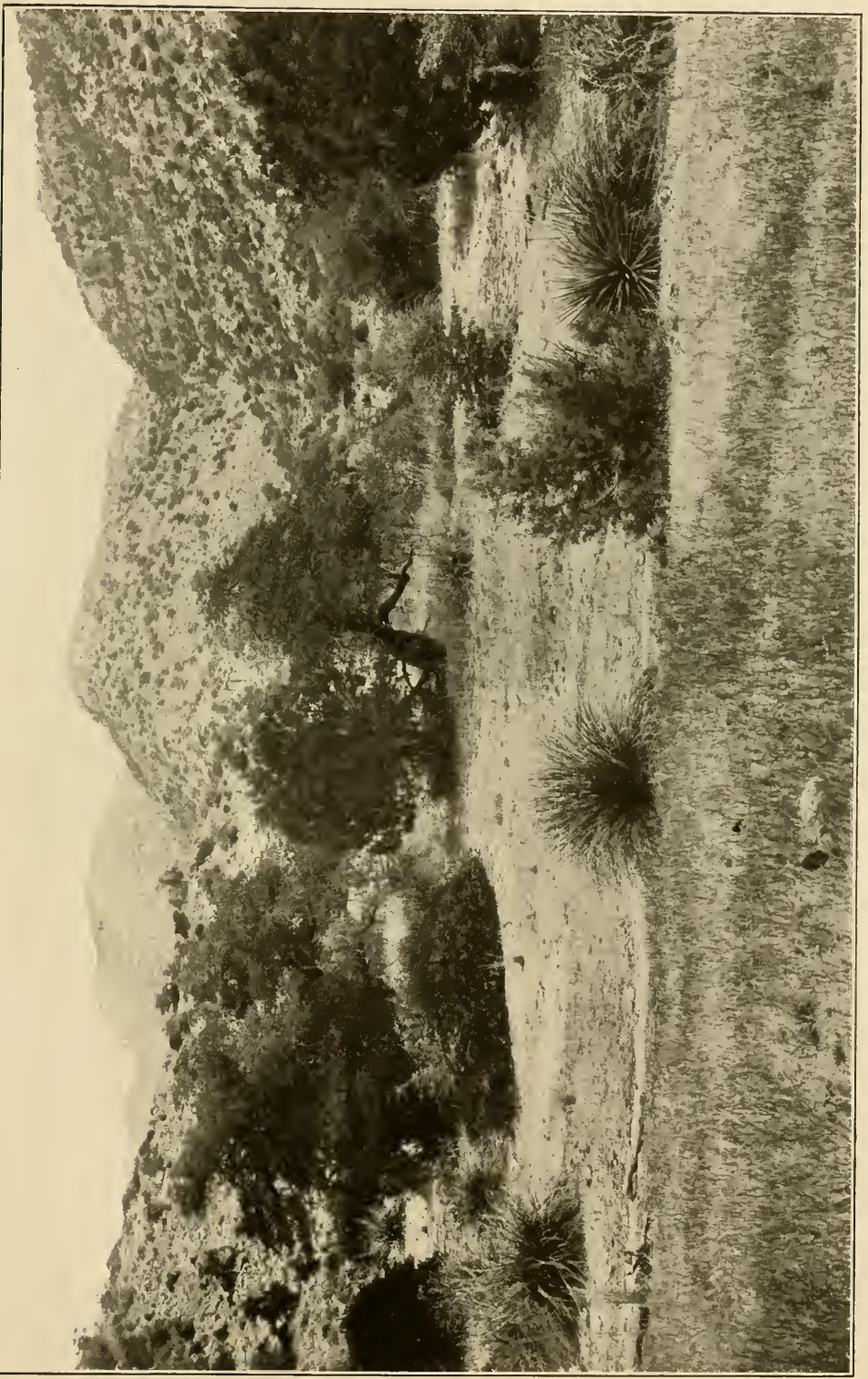





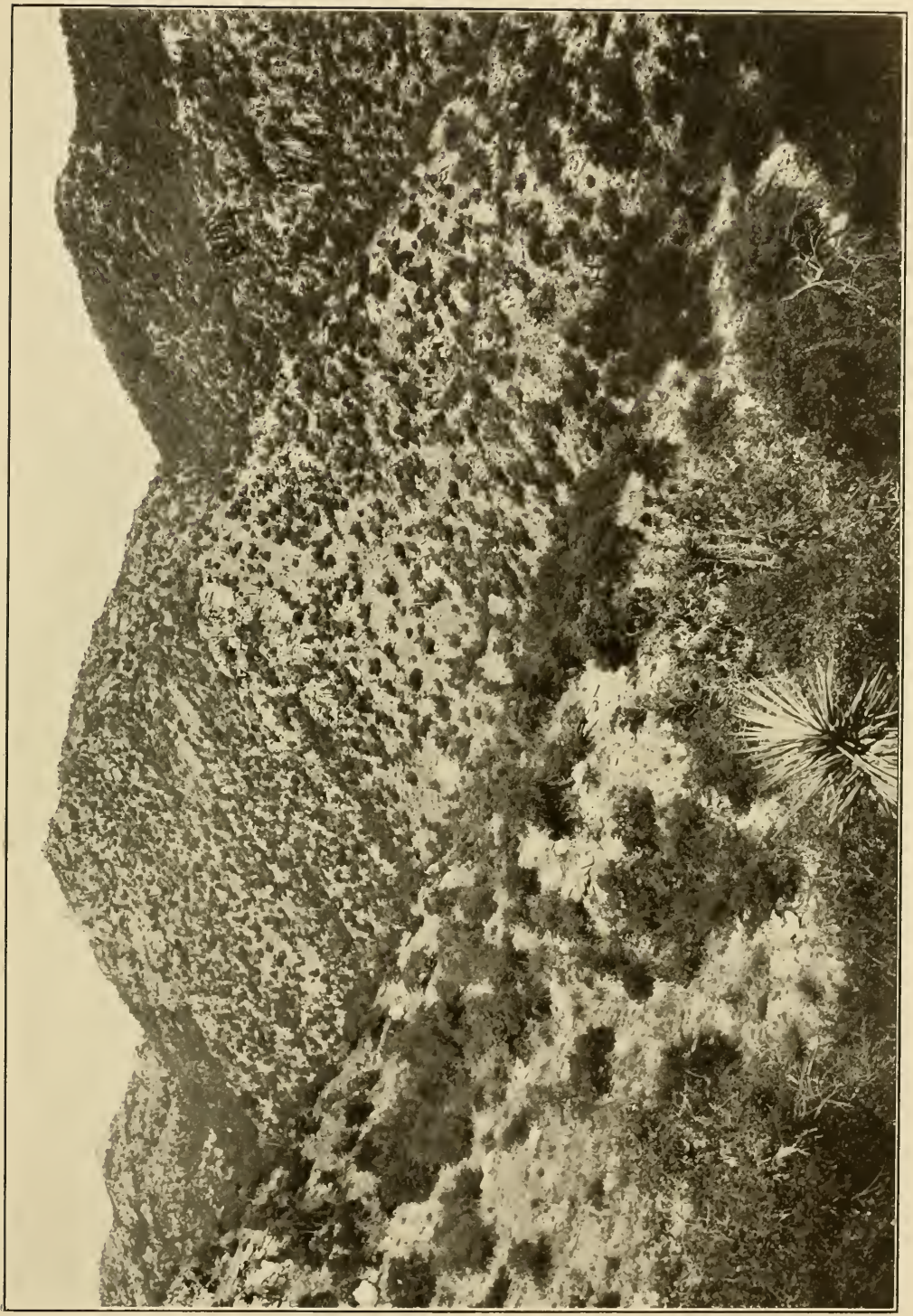

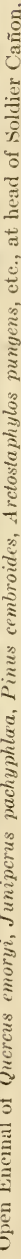





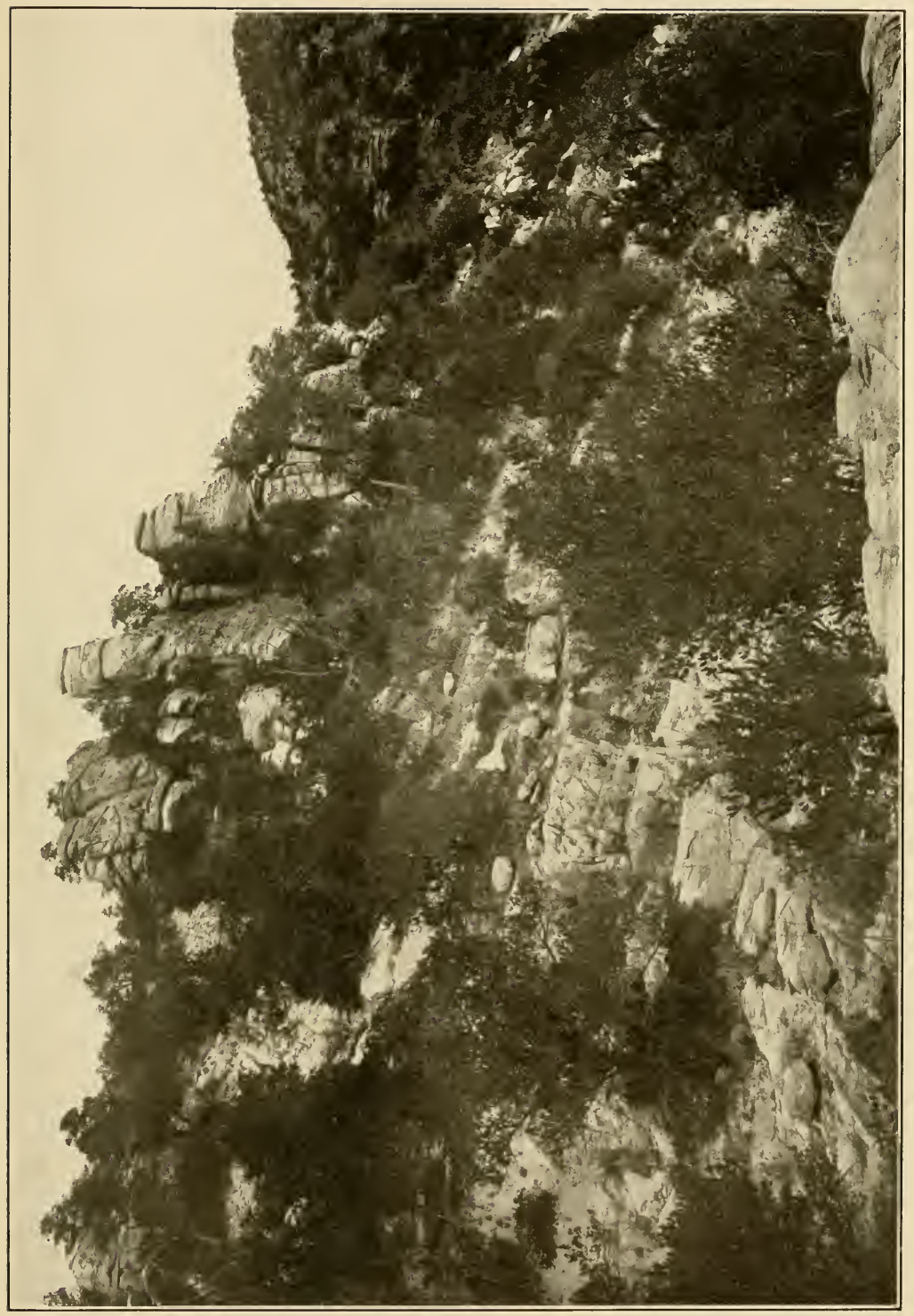





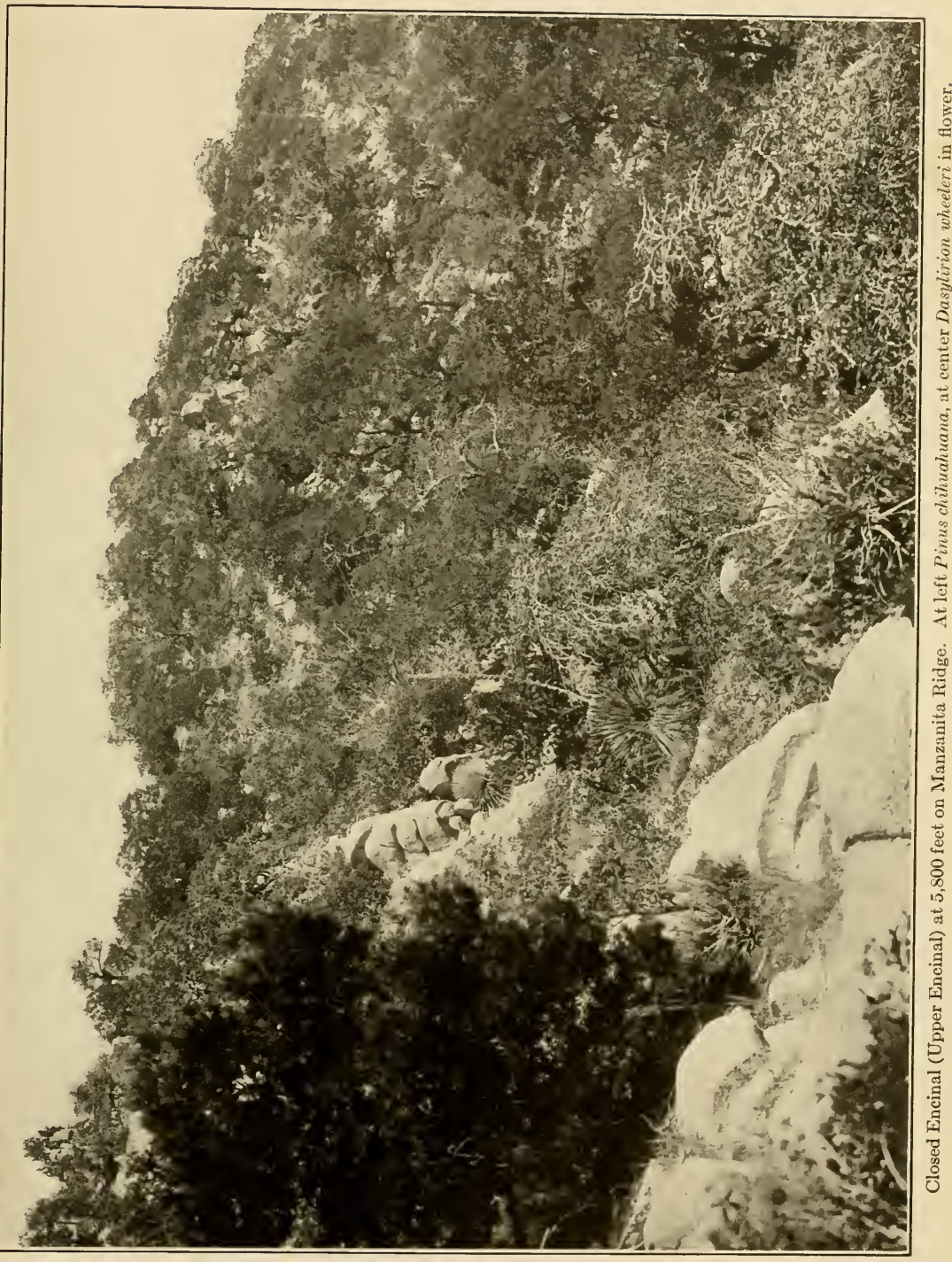





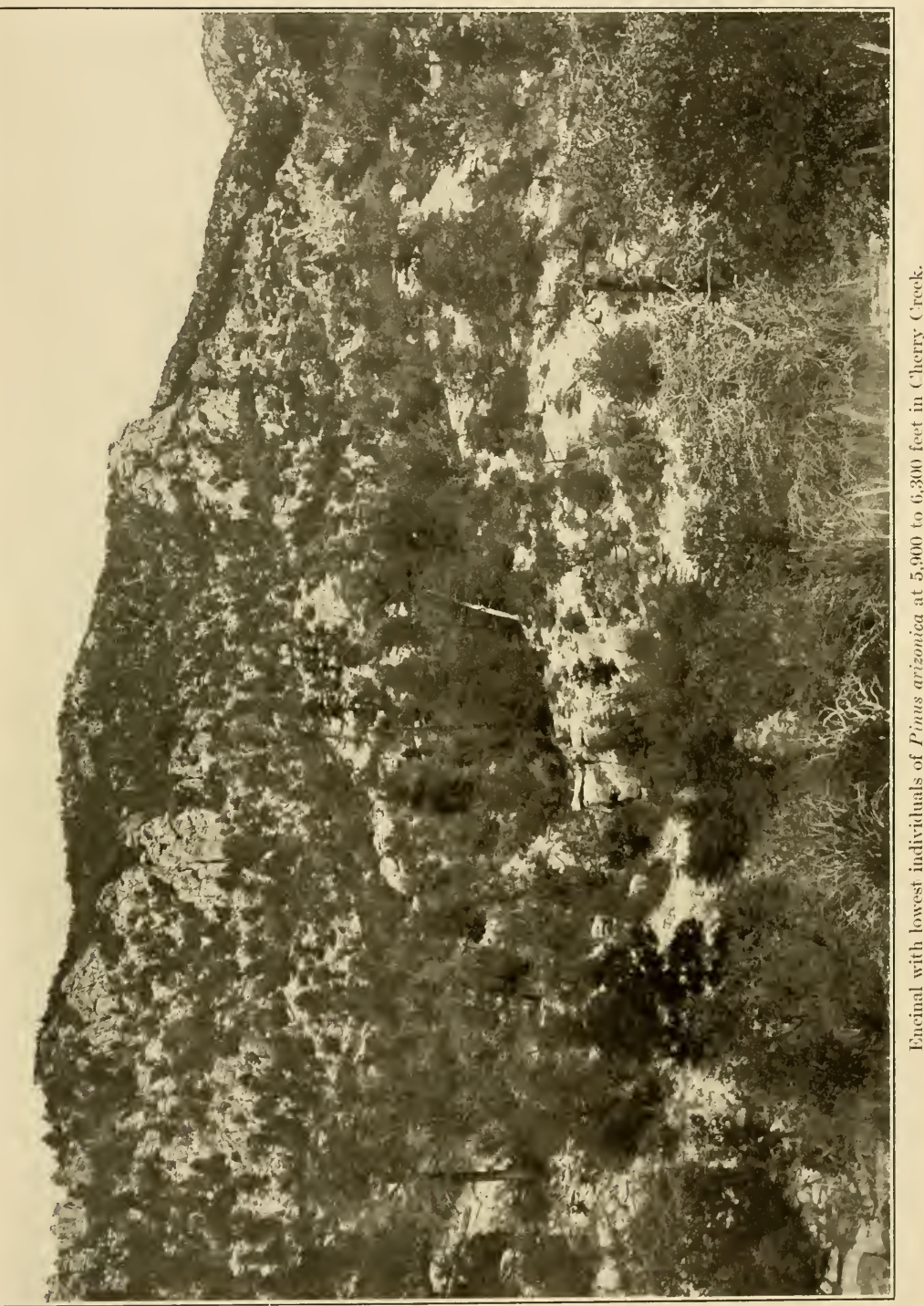





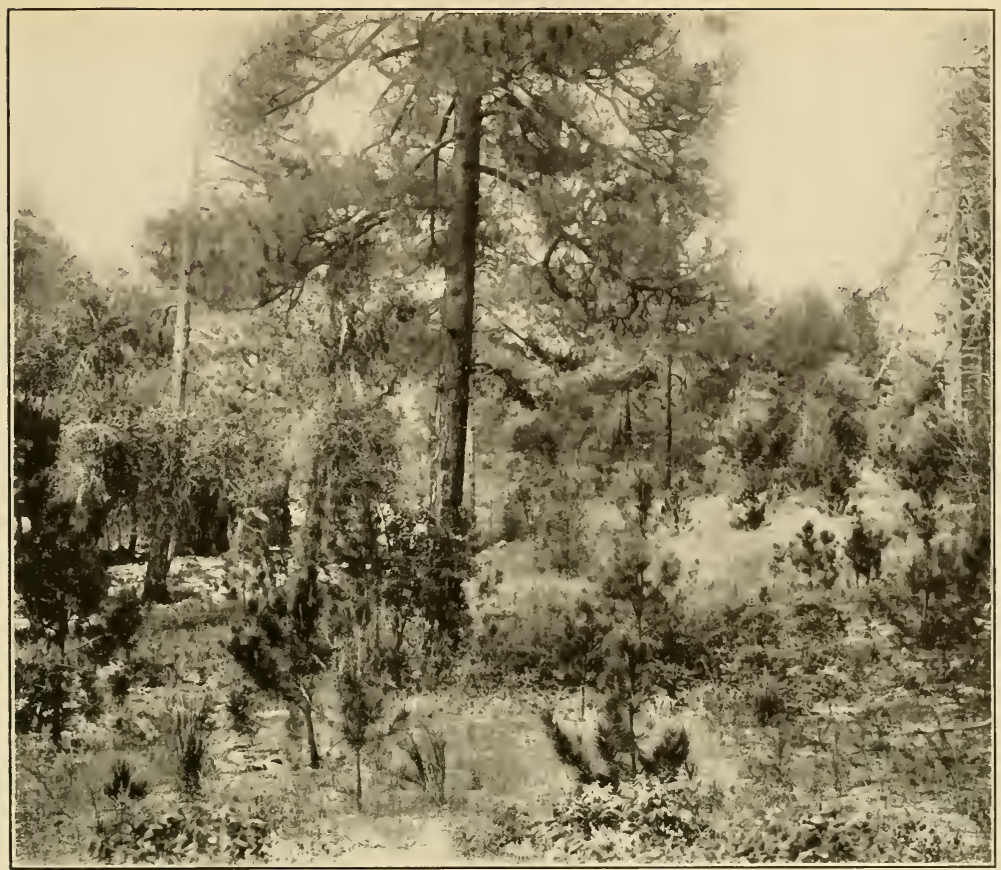

A. Flood-plain in Bear Cañon at 6,000 feet, with Pinus arizonica, Populus jamesii, an open earpet of summer-active herbaeeous perennials, and sporobolus confusus.

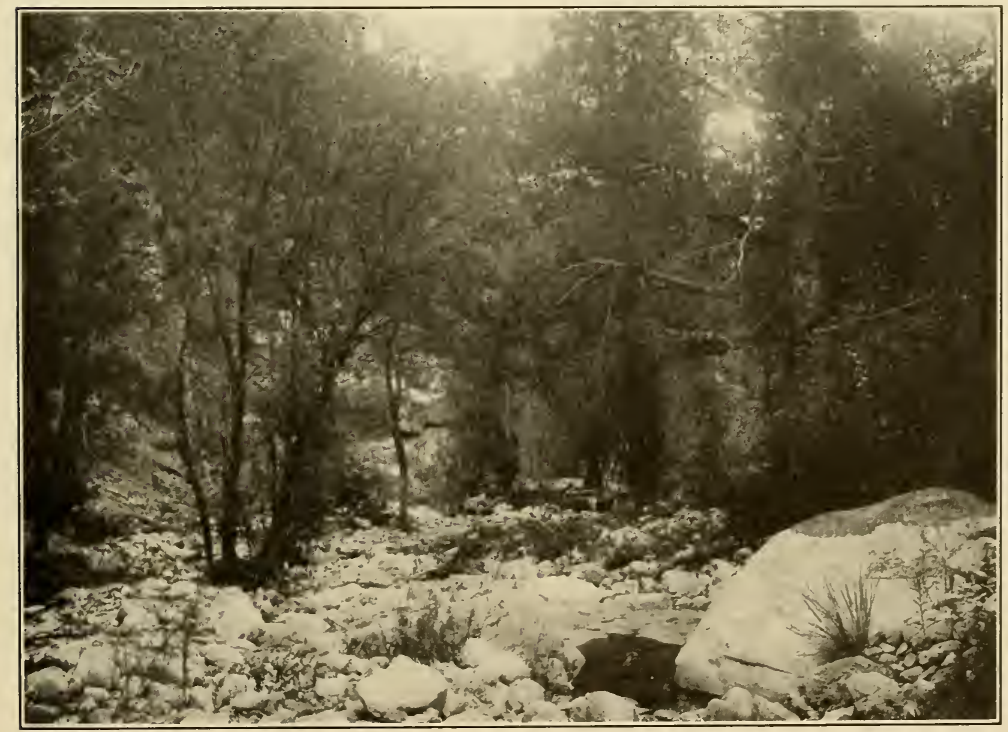

B. Streamway in Bear Cañon at 6,000 feet, with Pinus arizonica, Juglans rupestris, and Vitis arizonica. 



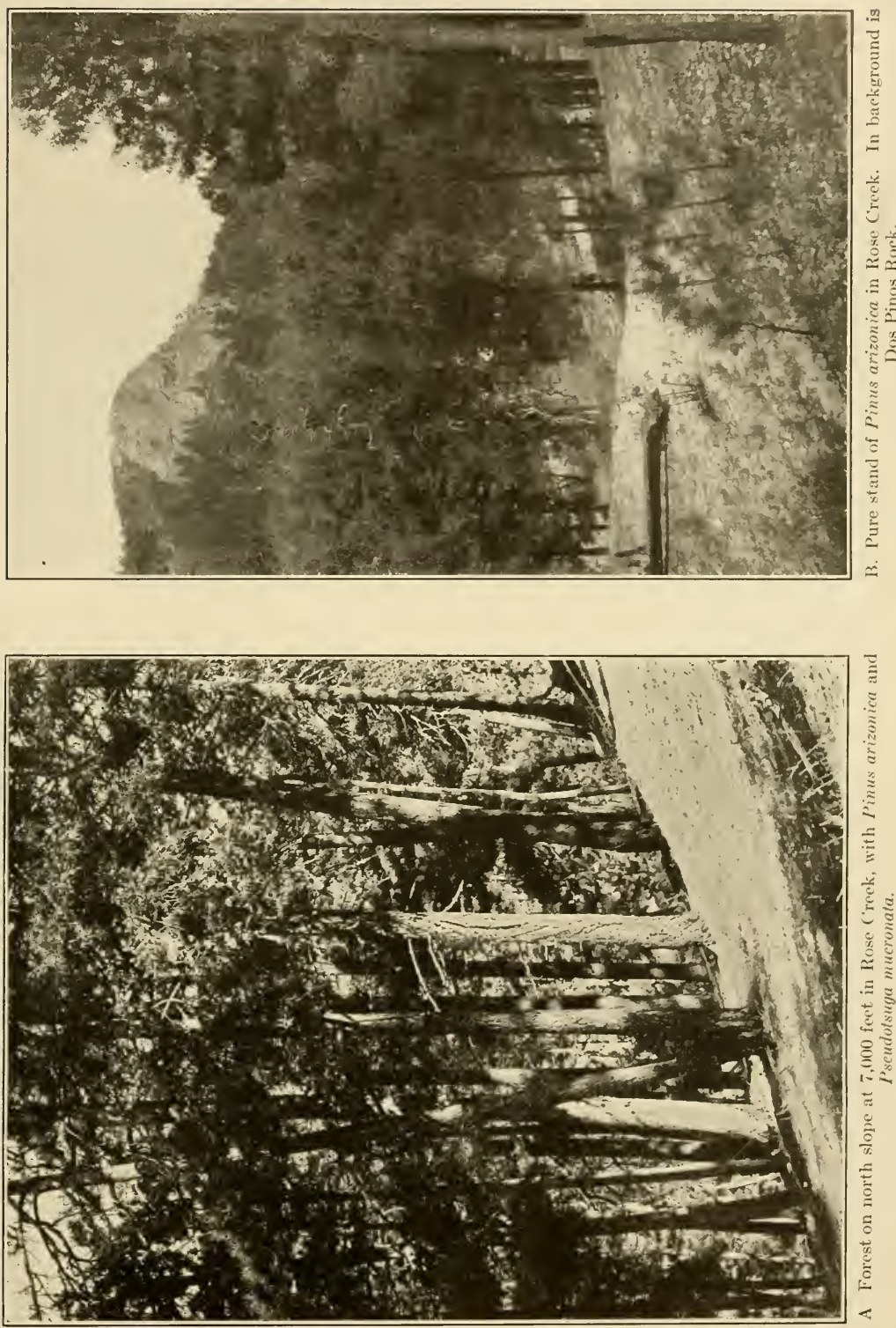



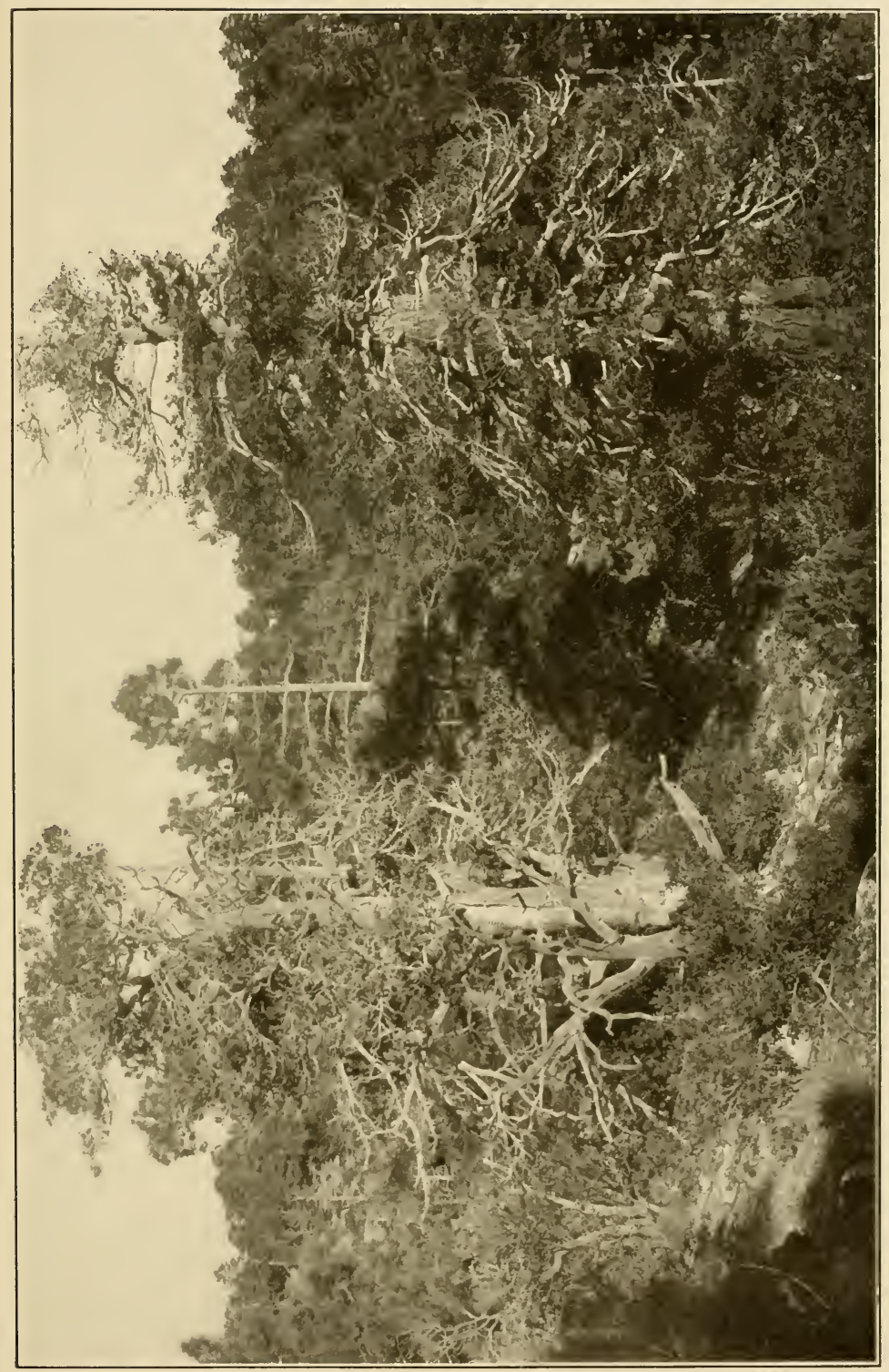





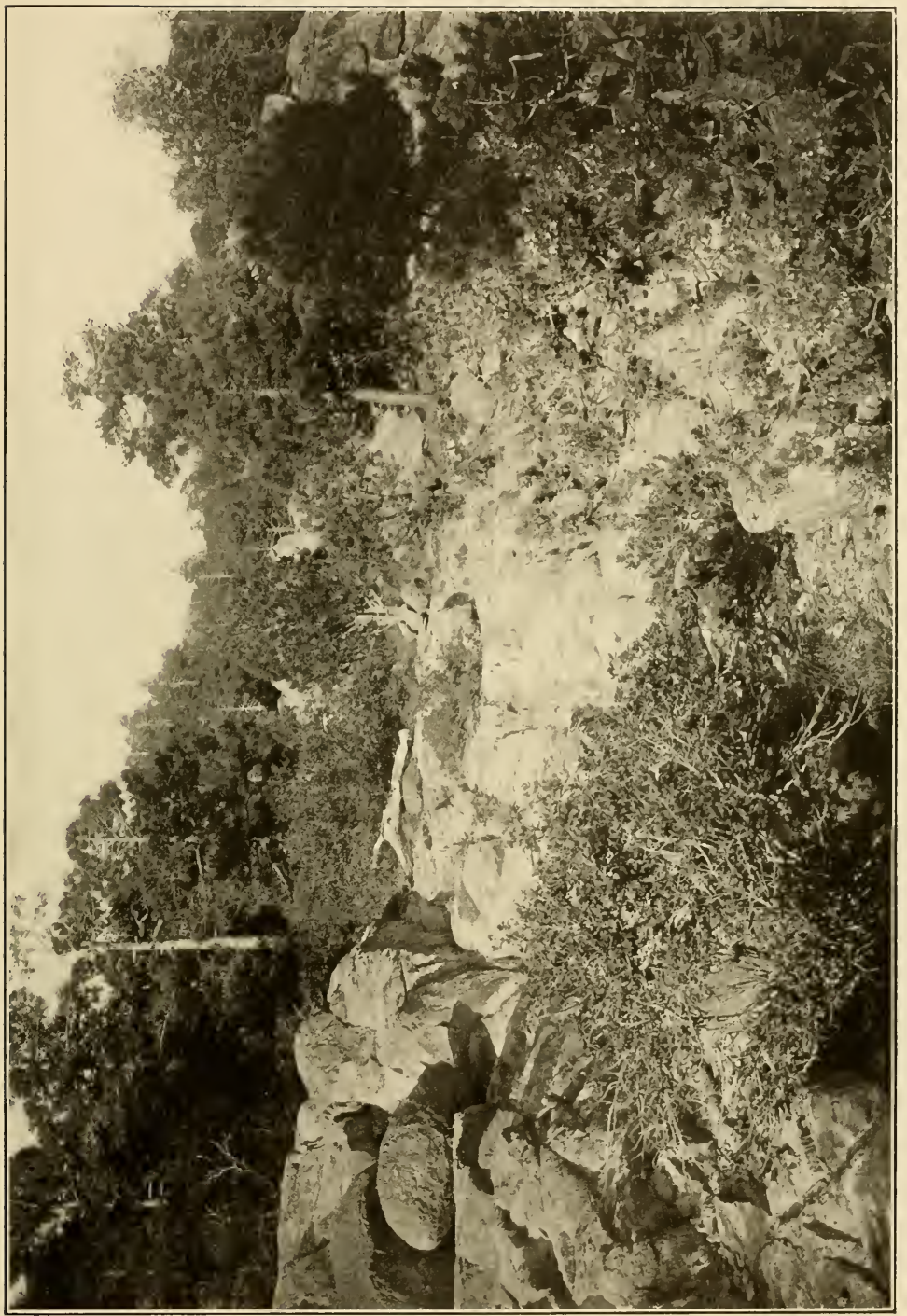

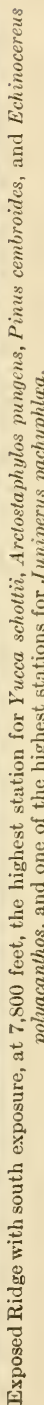





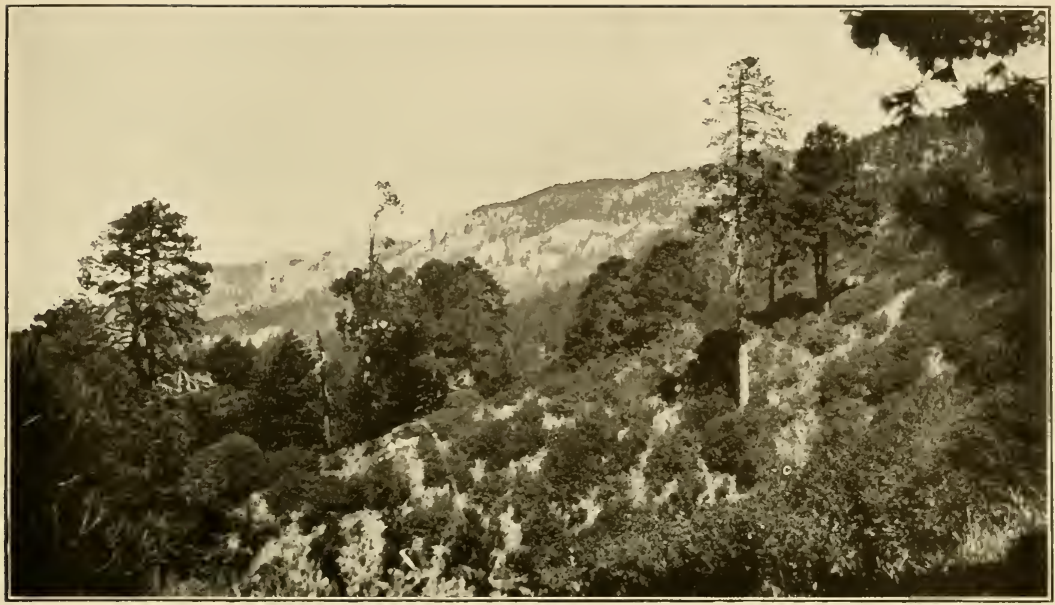

A. Looking toward south face of Mount Lemmon from erest of Marshall Gulch, near site of $\rightarrow, 0(0)$-foot climatological station. Pinus arizonica and scrub of Quercus reticulata.

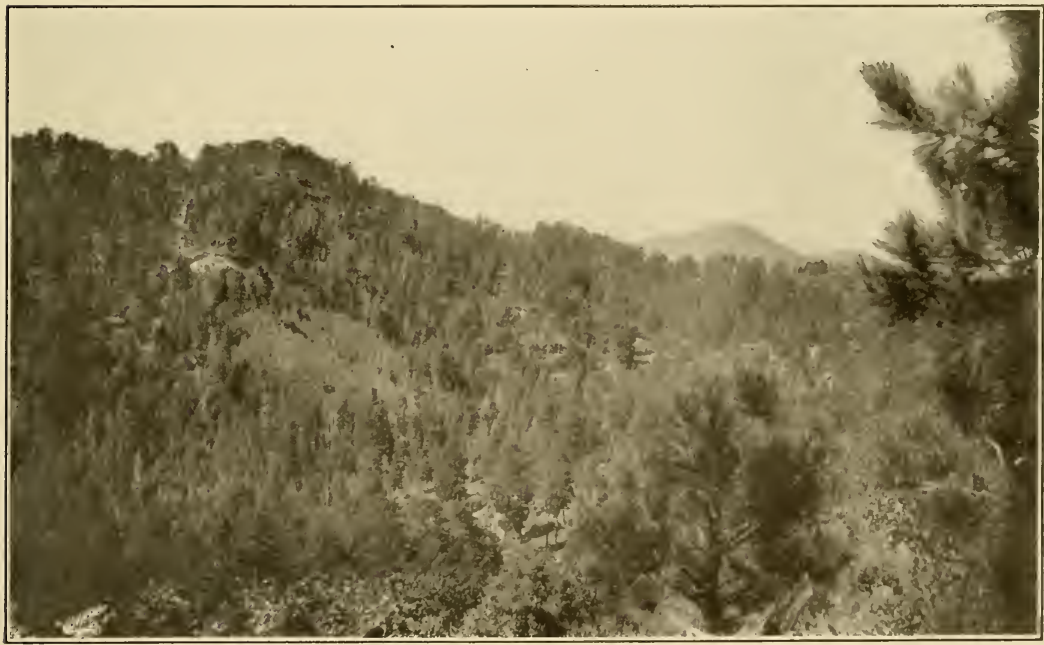

B. Looking southwest into Marshall Guleh. The open area in the forest is a thicket of Populus tremuloides. 



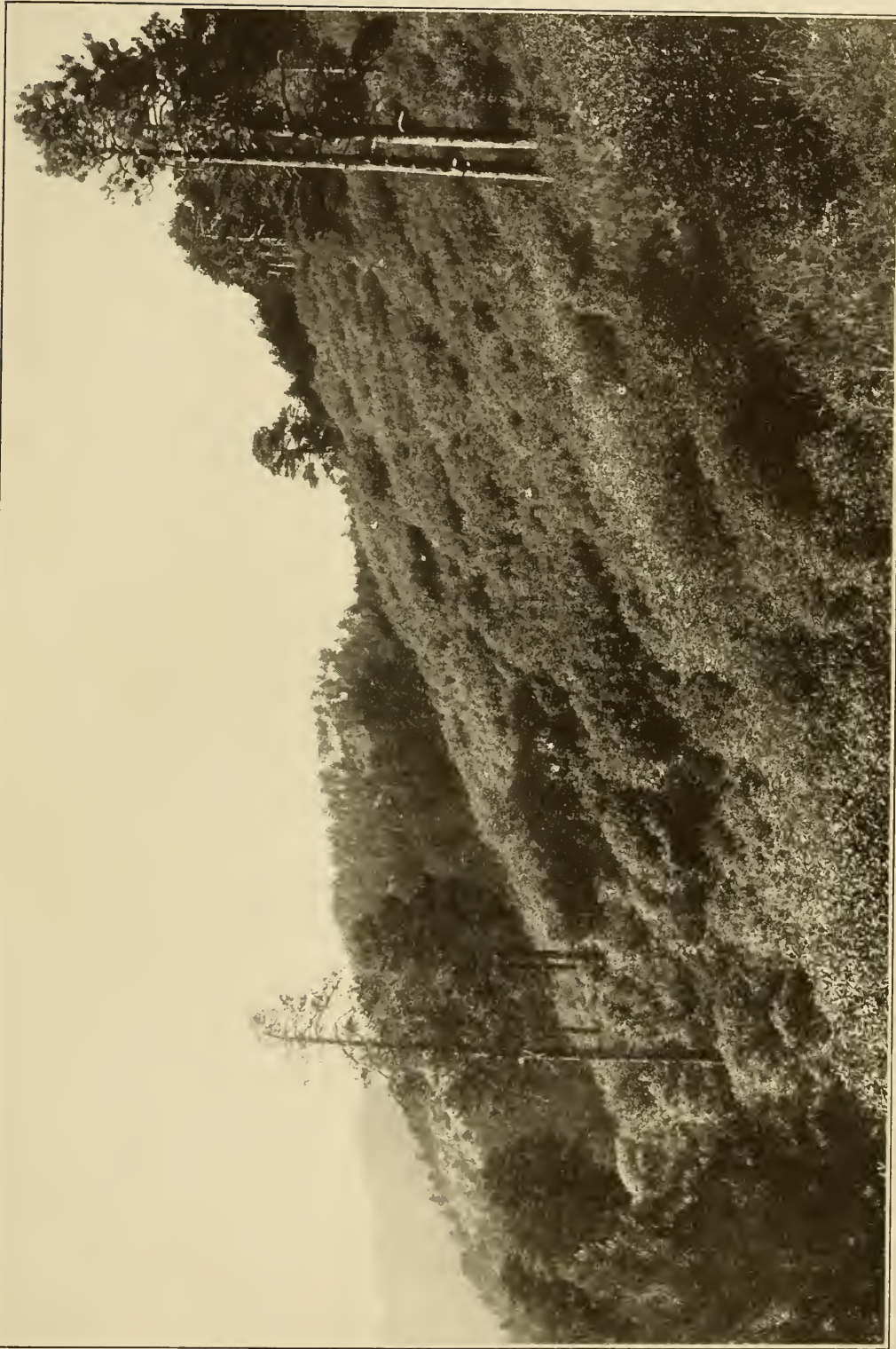





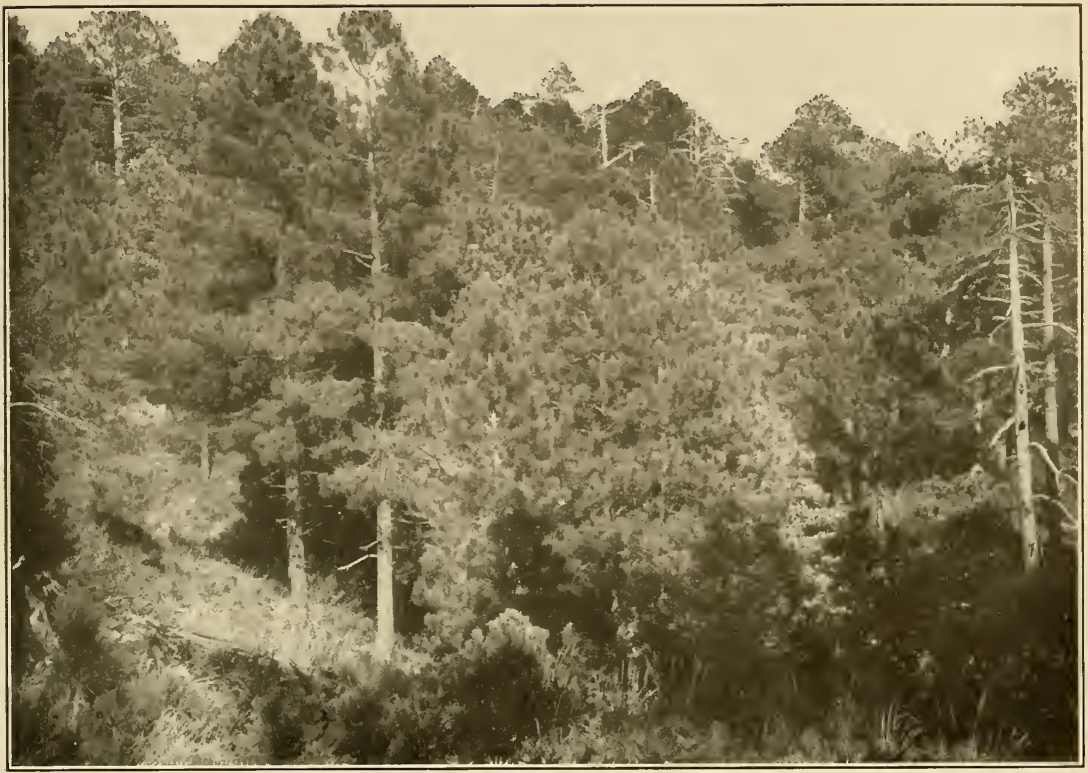

A. Typical heavy stand of Pinus arizonica on a bench in Marshall Guleh at 7,800 fect.

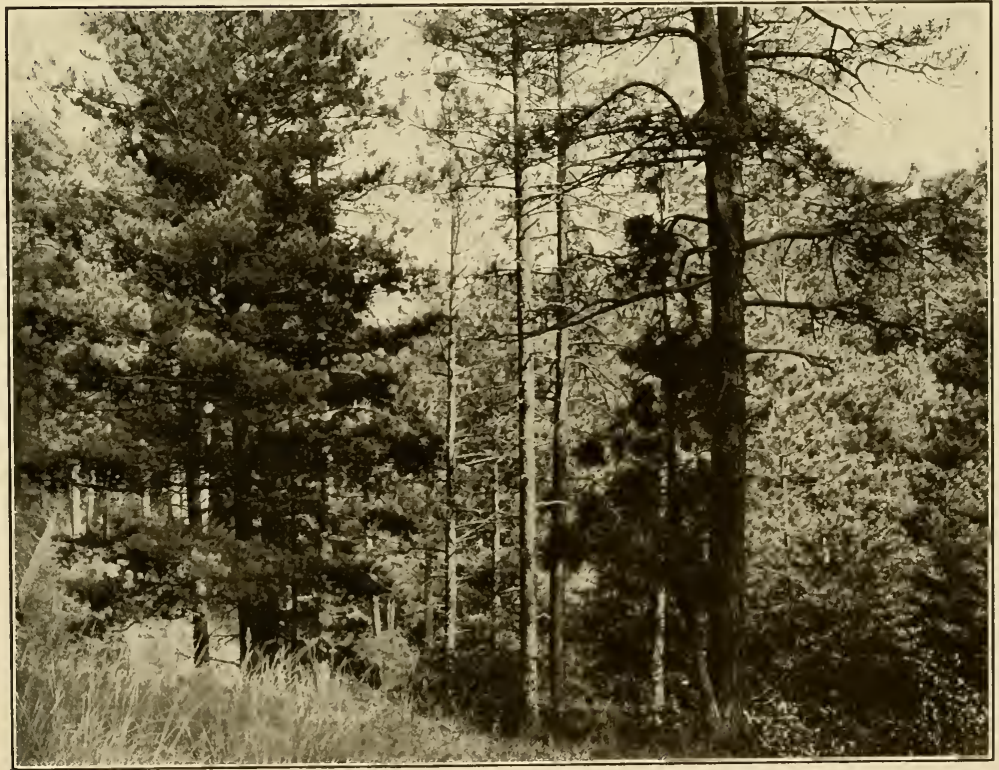

B. Looking east along south-facing slope of Marshall Gulch at 7,700 feet. The bunch-grass is Muhlenbergia virescens. 



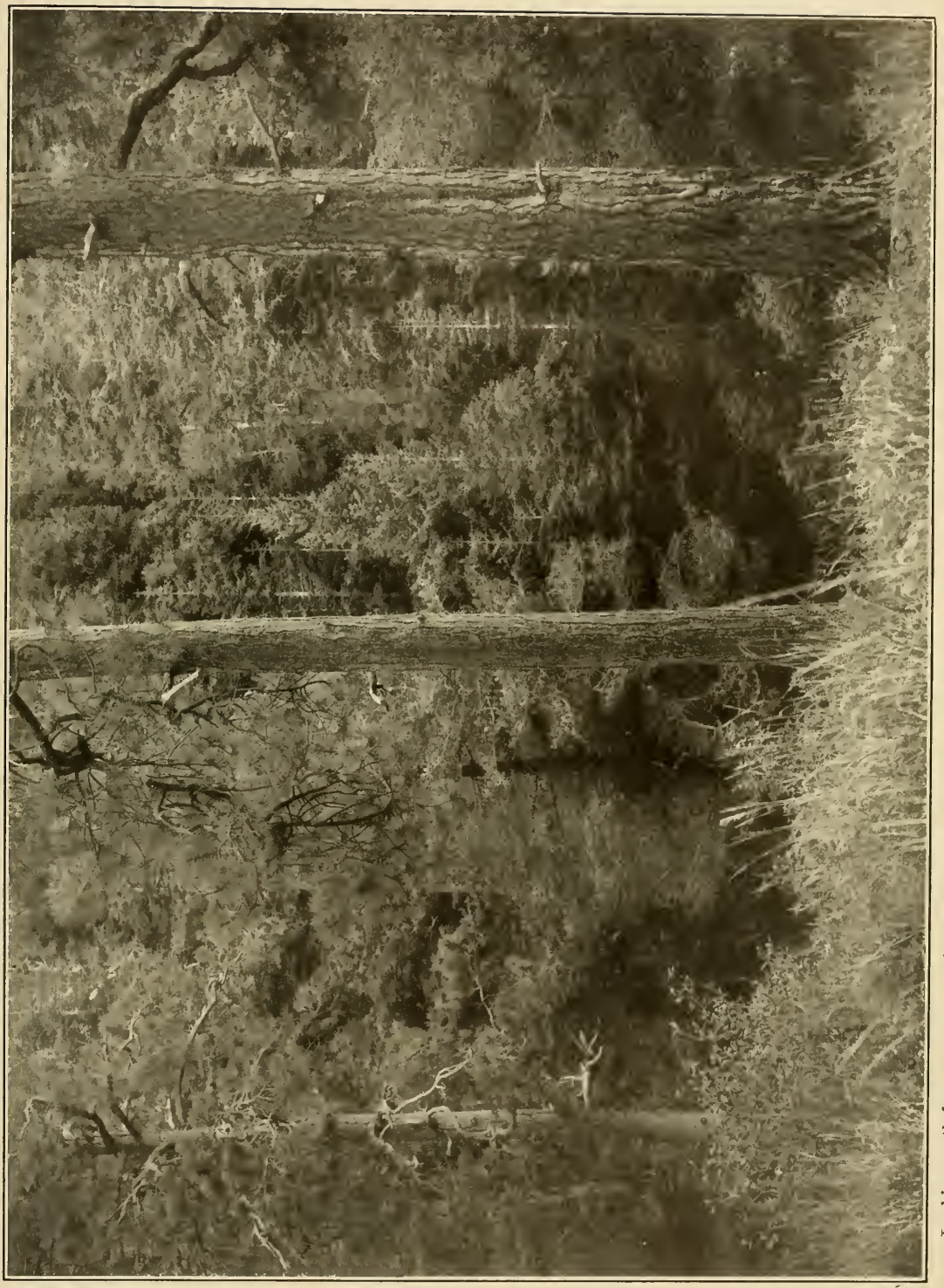





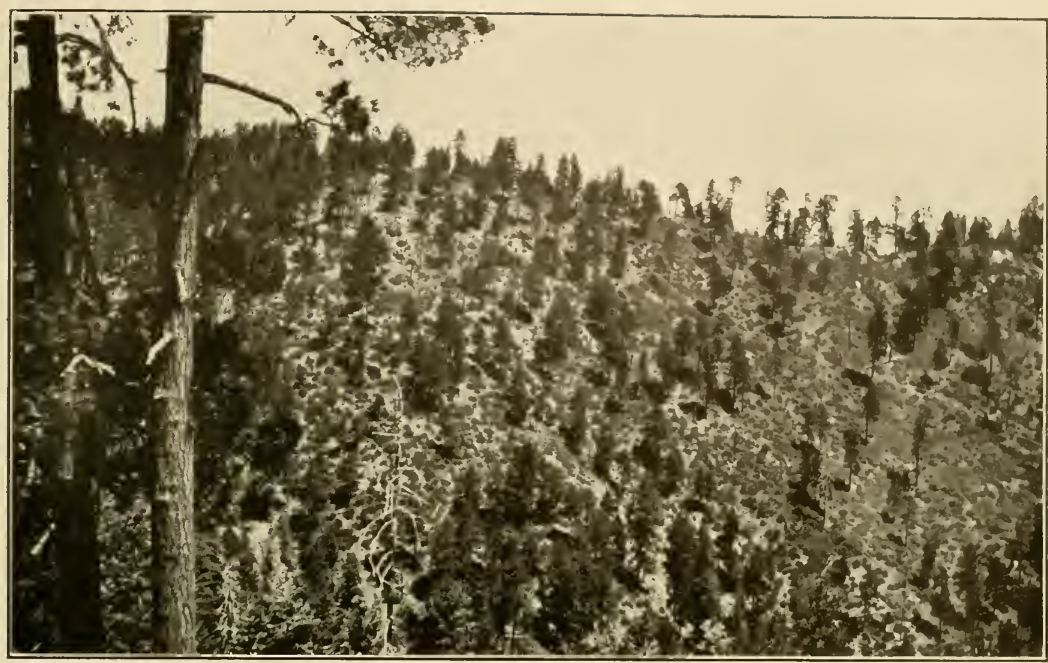

A. Open Forest on Steep South Slopes of Main Ridge at $>, 500$ feet. The shrubs are Quercus reticulata.

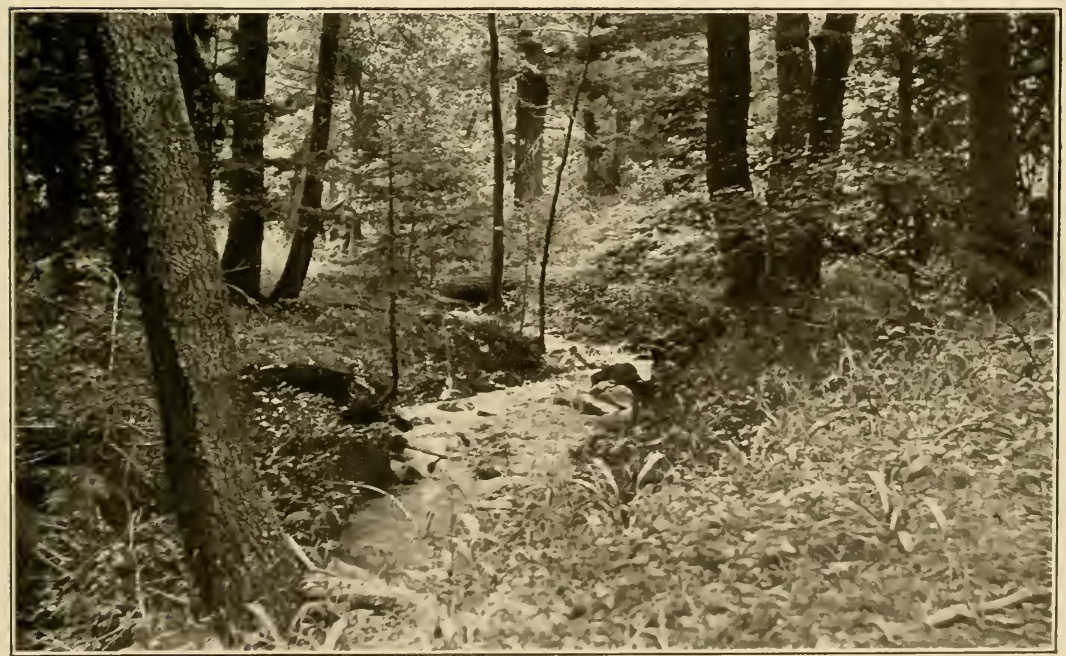

B. Stream and Narrow Flood-plain in Marshall Gulch near Montane Garden. Alnus acuminata, Acer brachypterum, and Abics concolor. 



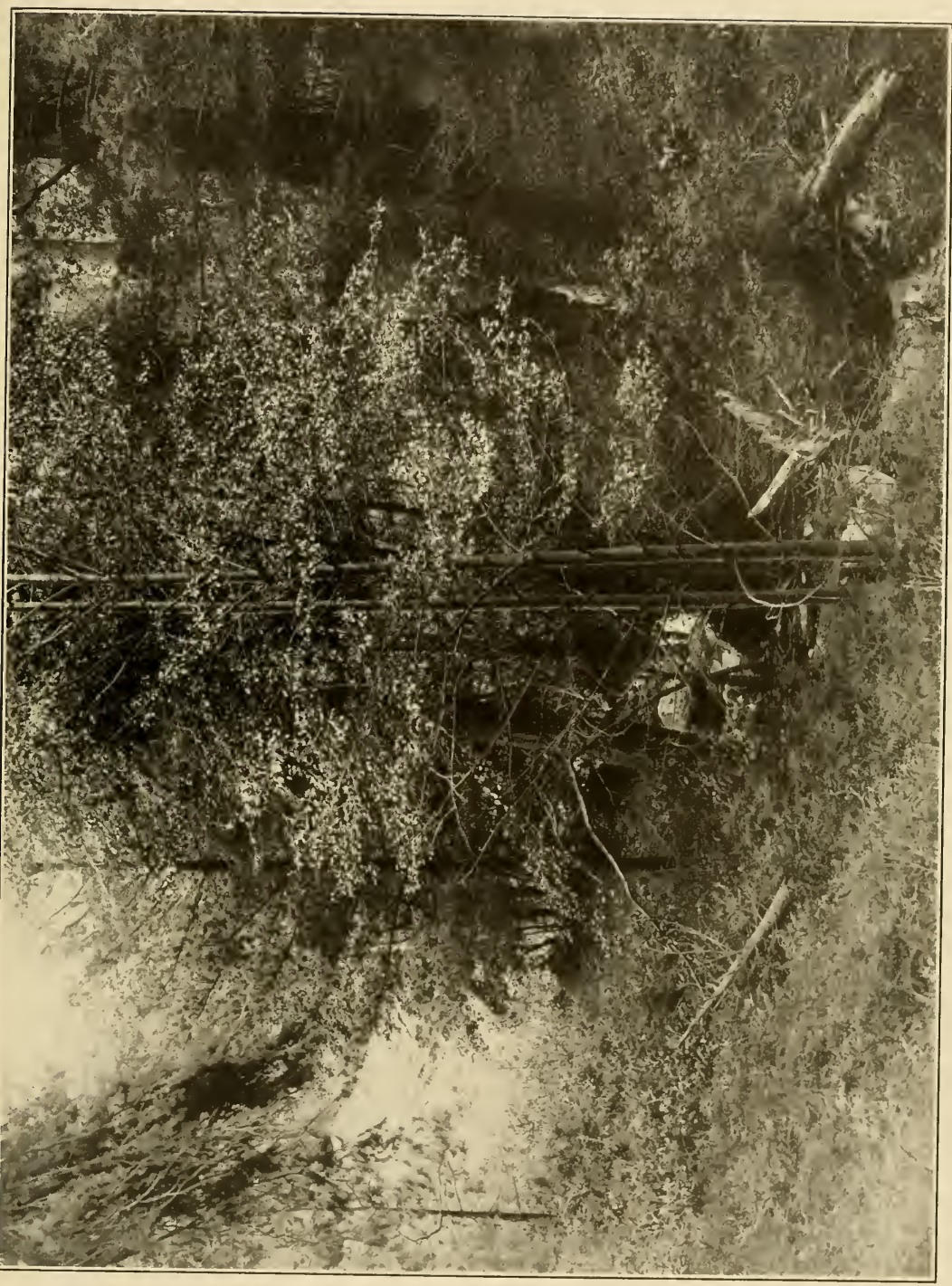





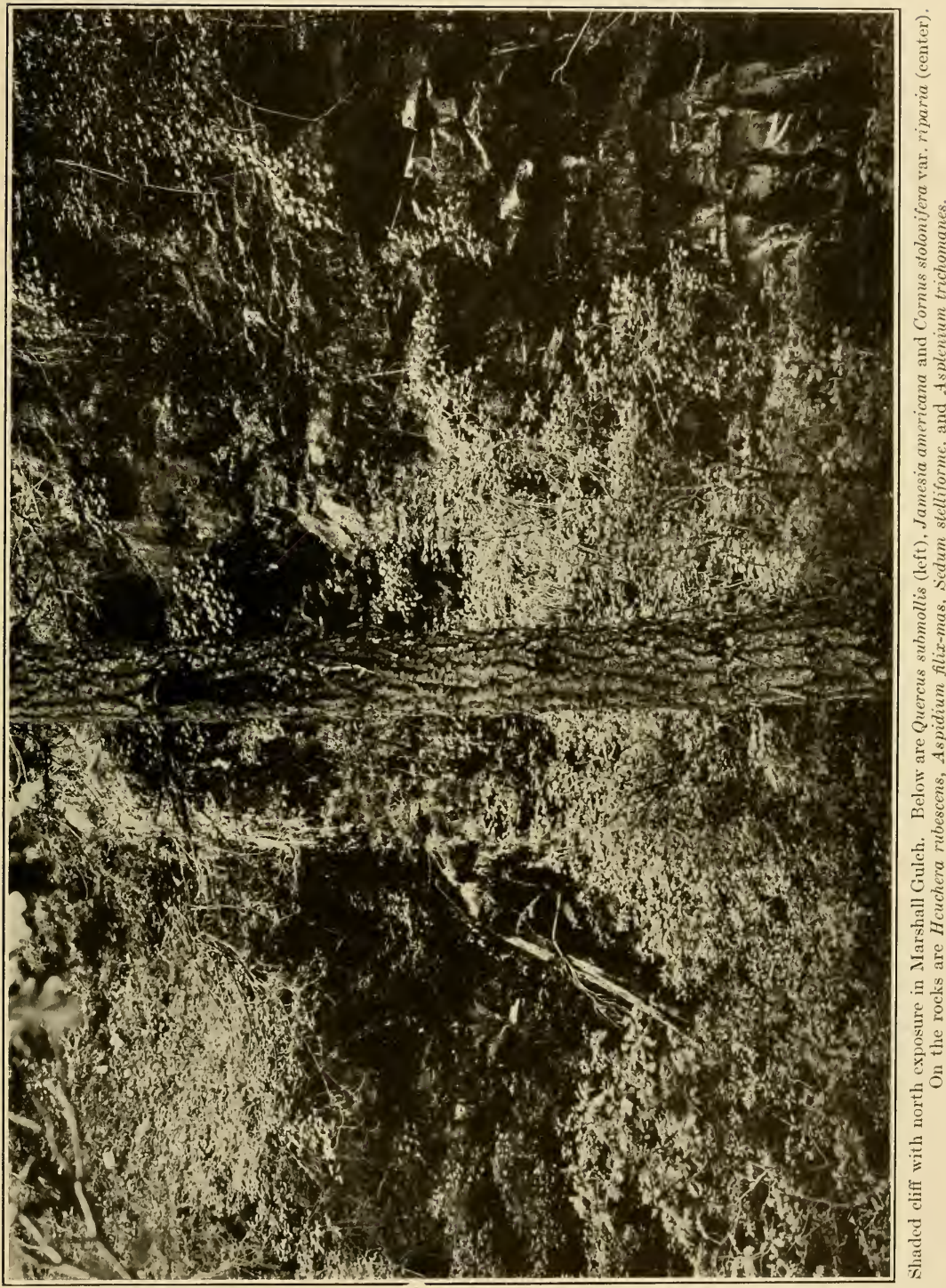





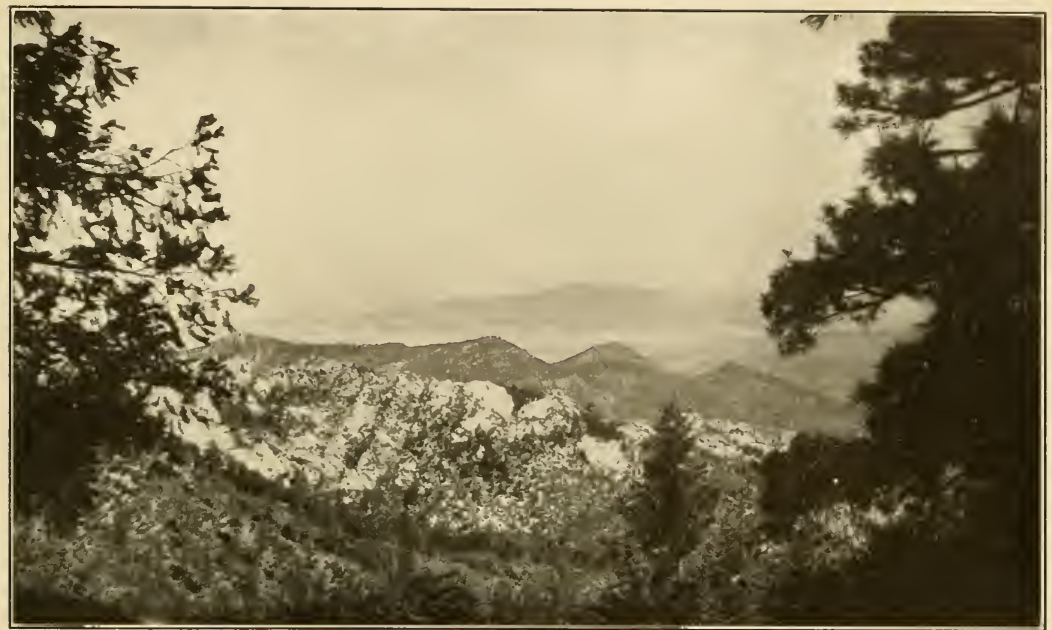

A. Looking northwest from main ridge toward Samaniego Ridge.

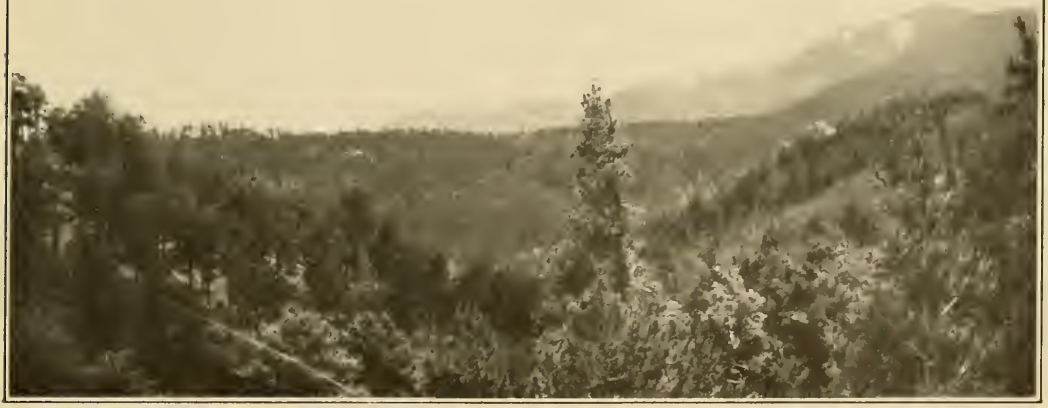

B. Looking east along main ridge of Santa ('atalinas from a point east of $\$$ Iount $L$ ('mmon at about $\$, 600$ feet. 




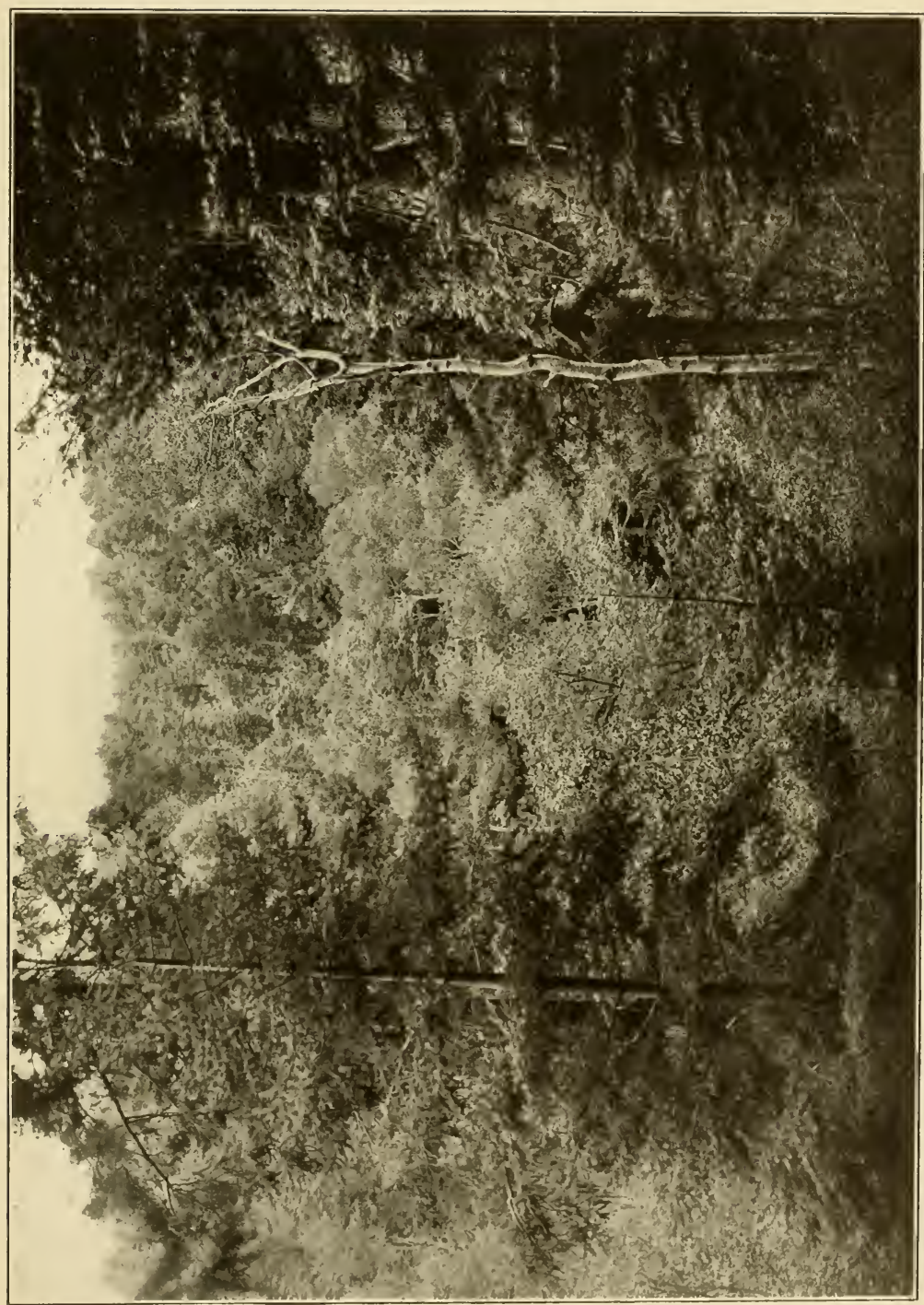





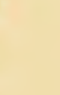






$-1+1=$

$+1+2+1$

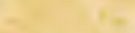

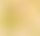

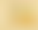

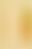


S. 